DOUTORADO EM CiÊNCIAS DA COMUNICAÇÃo

Linha de PESQUiSA: TEORIA E PESQUISA EM COMUNICAÇÃo

\title{
A Leitura Sob o Signo da RelaÇão LER COMO ATO DE COMUNICAC̃̃̃o SOCIAL
}

PERCURSO TEÓRICO E EXPERIMENTO EM SARAUS

DOUTORANDa: Katiuscia da CUNha LoPes FogaÇa

Orientadora: Profa. Dra. Cremilda Medina 


\section{Universidade de São Paulo}

Escola de Comunicações e Artes

\section{A LEITURA SOB O SIGNO DA RELAÇÃO Ler como ato de Comunicação Social}

Percurso teórico e experimento em saraus

KatiusCiA DA CUNHA LOPES FogAÇA Tese apresentada à Comissão de Pósgraduação da Escola de Comunicações e Artes da Universidade de São Paulo, como exigência para obtenção do título de Doutora em Ciências da Comunicação - Teoria e Pesquisa em Comunicação, sob a orientação da Profa. Dra. Cremilda Medina.

\section{0}


Banca Examinadora

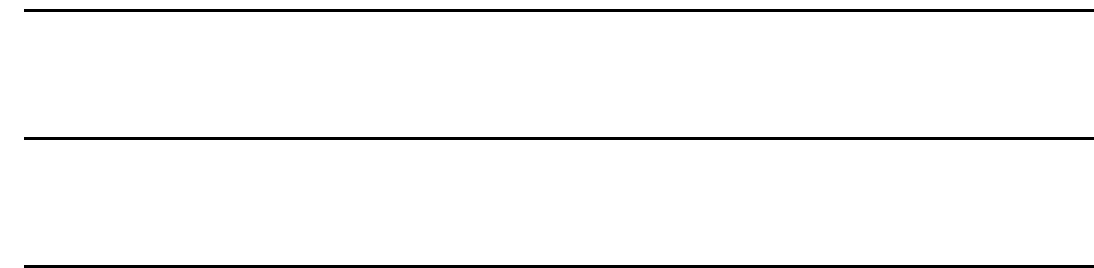


À rede de amigos, presentes fisicamente ou através de seus trabalhos acadêmicos no Fórum Permanente Interdisciplinar da Escola de Comunicações e Artes da USP que, com suas inquietudes, me ensinaram a desconfiar do óbvio. 


\section{AGRADECIMENTOS}

À Izaura Marques, luz deste trabalho. Pelo seu exemplo de vida e pela prazerosa presença em alguns saraus.

À Cremilda Medina, orientadora de fato. Mais que professora; amiga e inspiração. Ao Sinval Medina, "nosso" parceiro de ideias e ideais, por seu afeto e pelo legado de seus romances.

À minha mãe, Lindinalva, por sua eterna e incondicional confiança na minha capacidade de ser, acima de tudo, eu mesma. Ao meu pai, Toninho, que, ao lado de minha mãe, não abriu mão de me dar amor e, dentro de suas possibilidades, a melhor educação. E não foi apenas a escolar...

Ao companheiro e marido Welton Fogaça que pegou o bonde da pesquisa em sua segunda metade, por sinal, o trecho mais acidentado. Suportou minhas inseguranças e inquietudes e aceitou compartilhar meus "achados" durante a pesquisa. Como bom advogado nunca deixou de defender meus direitos. Como parceiro, insistiu em cobrar os meus deveres.

Aos colegas do Fórum Permanente Interdisciplinar, pelo aprendizado coletivo. Especialmente aqueles que tivemos a oportunidade de compartilhar experiências viscerais nos trabalhos de pesquisa: Márcia Blasques, Raul Osório, Patrícia Patrício, Paulo da Silva Quadros e Alex Sander Alcântara. Também Renato Seixas, Teresa Otondo e Ana Cristina Olmos.

Às relações que costurei durantes os saraus.

À comunidade São Paulo de Perfil - escritores, autores e leitores.

Aos alunos da disciplina Trabalho de Conclusão de Curso com quem compartilhei as dúvidas da incompletude de uma pesquisa e este me responderam retribuindo respeito e carinho.

Àqueles que me acompanham nesses últimos anos. Eles sabem o quanto são especiais para mim. 
Para voar não basta ter asas, é preciso ser livre.

.. a literatura, como toda arte, é uma confissão de que a vida não basta. 


\section{SUMÁRIO}

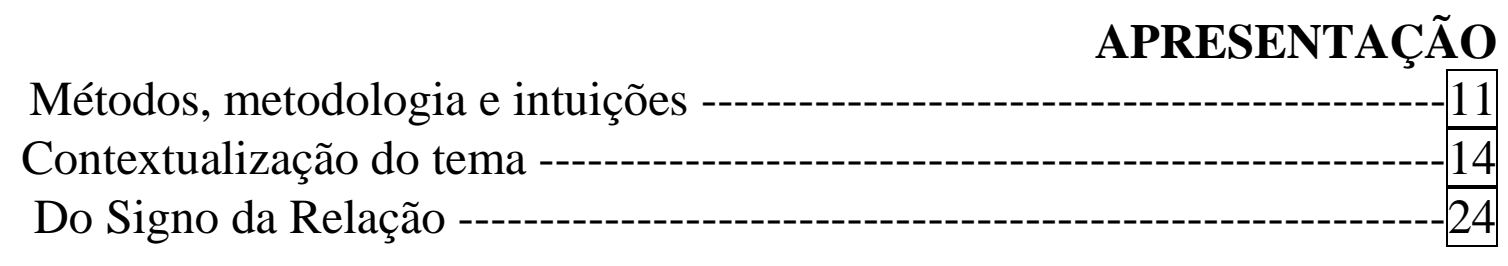

CAPÍTULO 1

Cruzeiro pelos Saraus

CAPÍtULO 2

Quem é Izaura?

CAPÍtULO 3

Isaurau: o conto da sereia Izaura

CAPÍTULO 4

Escala epistemológica

CAPÍTULO 5

Escala prosódica 110

CAPÍTULO 6

Escala escolar 123

CAPÍTULO 7

Da política pública ao público politizado $-153$

CAPÍTULO 8

Signo da Relação: a construção social dos sentidos $-176$

CAPÍtULOO 9

Percurso São Paulo de Perfil - Relações, nexos e conexões 195

CAPÍtULO 10

Destino final - Tramas e amarrações $-203$

BIBLIOGRAFIA

Referências bibliográficas $-209$ 


\section{RESUMO}

Esta tese realiza uma anatomia investigativa teórica e laboratorial para problematizar o atual conceito predominante de leitura que está sedimentado em antigos paradigmas fragilizados por demandas sociais contemporâneas, principalmente os de Educação, Comunicação e de Cultura. A pesquisa elenca e convida para a reflexão sobre os elementos associativos à leitura que compõem o imaginário coletivo e que se sobressai nos estudos relacionados à leitura e à literatura. No bojo destas questões contemporâneas está uma inquietude levantada nessa tese a respeito dos paradigmas com que pensamos o processo, habitual ou esporádico, de ler; sobre o que realmente entendemos ser a leitura, quais conceitos, noções e imaginários que envolvem a questão, como estamos lidando com a problemática considerando contexto e demanda atual da sociedade. Sabemos que o ato de ler se transforma historicamente, e que, hoje, entre outros fatores, pelos avanços tecnológicos e opções e alternativas de suportes-canais, essas mudanças ocorrem no cotidiano, porém estas parecem não estar sendo muito bem acompanhadas e compreendidas; o que se lançou a fazer esta pesquisa, por reflexão teórica e experimentos de saraus. Com isso, a proposta é dar uma contribuição para expandir a noção de leitura (com maior plasticidade e mobilidade do que os conceitos dogmáticos), combinada à noção de Comunicação Social sob o paradigma do Signo da Relação, condizente com as demandas e os anseios contemporâneos, onde a Leitura, mais do que um encontro forçado ou forjado entre leitor-texto-livro-autor (sujeito-objeto), é o fenômeno - o lugar e o momento - de comunhão, de comunicação, de troca dinâmica e sinérgica sempre entre leitores (sujeito-sujeito), ou seja, entre leituras, harmônicas ou não, mas sempre transformadoras.

Palavras-chaves: leitura, comunicação, comunicação social, educação, literatura, dialogia, São Paulo de Perfil, Signo da Relação 


\begin{abstract}
This thesis doc makes a theoretical and investigative anatomy laboratory to discuss the current prevailing concept of reading that is sedimented in old paradigms weakened by contemporary social demands, especially the Education, Communication and Culture. The survey lists and calls for reflection on the elements associated with reading that make up the collective imagination and excels in studies related to reading and literature. In the context of these contemporary issues are a concern raised in this thesis on the paradigms of our thinking process, regular or sporadic reading, about what we really mean by reading, what concepts, ideas and imagery surrounding the issue, as we dealing with the problem context and considering the current demand of society. We know that the act of reading becomes historically and today, among other factors, by technological advances and options and alternative-media channels, these changes occur in everyday life, but these seem not being well monitored and understood, the who fell doing this research, by theory and experiments soirees. Thus, the proposal is to contribute to expand the notion of reading (with greater plasticity and mobility than the dogmatic concepts) combined the concept of Media under the paradigm of the Sign of Appeal, in keeping with the demands and wishes contemporary, where the reading rather than a forced or forged encounter between reader-textbook-author (subject-object), is the phenomenon - the place and time - of communion, communication, and dynamic exchange between readers always synergistic (subject-subject), or between reads, harmonic or not, but always transforming.
\end{abstract}




\section{RESUMEN}

Esta doctorado hace un laboratorio de anatomía teórica y de investigación para examinar el concepto que actualmente predominante de la Lectura que se sedimentan en los viejos paradigmas contemporáneos debilitado por las demandas sociales, especialmente la Educación, Comunicación y Cultura. Las listas de encuestas y exigen una reflexión sobre los elementos asociados con la lectura que conforman el imaginario colectivo y se destacan en los estudios relacionados con la lectura y la literatura. En el contexto de estos temas contemporáneos son una preocupación expresada en este doctorado en los paradigmas de nuestro proceso de pensar, leer periódicos o esporádicos, sobre lo que realmente queremos decir por la lectura, ¿qué conceptos, ideas e imágenes en torno al asunto, ya que tratar con el contexto del problema y teniendo en cuenta la demanda actual de la sociedad. Se conoce que el acto de lectura se convierte en histórico y actual, entre otros factores, por los avances tecnológicos y las opciones y los canales alternativos-medios de comunicación, estos cambios se producen en la vida cotidiana, pero estos parecen no estar bien monitoreados y entendidos, la que se cayó haciendo esta investigación, por la teoría y los experimentos veladas. Por lo tanto, la propuesta es contribuir a ampliar la noción de lectura (con mayor plasticidad y movilidad que los conceptos dogmáticos) combinado el concepto de medios de comunicación bajo el paradigma de la señal de valor, de acuerdo con las exigencias y deseos contemporáneos, donde la lectura en lugar de un forzado o falsificado encuentro entre lector-libro-texto-autor (persona-cosa), es el fenómeno - el lugar y el tiempo - de la comunión, la comunicación y el intercambio dinámico entre los lectores siempre sinérgica (personapersona), o entre lecturas, harmónica o no, pero siempre en transformación. 


\section{APRESENTAÇÃO}

\section{Métodos, metodologia e intuições}

O presente trabalho persegue um propósito deste as pesquisas de mestrado, tentando mapear o imaginário de leitura, relacionando as teorias de comunicação contemporâneas, particularmente o Signo da Relação, com as teorias literárias como contribuição de compreensão dos fenômenos atuais de hábitos de leitura. A pesquisa pretende, assim, realizar uma anatomia problematizando o conceito de leitura sedimentado em antigos paradigmas fragilizados por demandas sociais contemporâneas, principalmente os de educação e de cultura, elencando os elementos associativos à leitura que compõe o imaginário coletivo.

Com o trabalho, pretende-se dar uma contribuição para a noção de leitura combinada à noção de comunicação social sob o paradigma do Signo da Relação ${ }^{1}$, condizente não só com as demandas, mas o que considero, com uma visão de pesquisadora, necessária para o estímulo de uma geração empenhada numa busca individual (não, individualista, pois o encontro do eu se dá pela busca altera do outro), e, como pessoas melhores em si mesmas, possam ser melhores em sociedade.

Quando o assunto é hábito de leitura, o debate gira em torno das preferências individuais e afinidades de grupos que compartilham sistemas culturais semelhantes. Visualizemos uma sala de aula em que alunos do ensino médio e sua jovem professora de literatura entram em conflito. A professora defende a leitura dos clássicos, consagrados pela crítica especializada, mas os alunos contestam dizendo que os romances com finais felizes e o mundo místico do Senhor dos Anéis e de Harry Potter

${ }^{1}$ Conceito trabalhado na trajetória acadêmica e profissional da professora doutora Cremilda Medina, em contraposição ao paradigma da divulgação ou difusão das informações, que nega a "eficiência" de um ato comunicativo com vetor único, sem atentar a demanda social. O Signo da Relação acredita que os processos comunicativos ocorrem de fato quando existe o papel mediador de agentes culturais que se consagraram, nas sociedades democráticas, como comunicadores. 
são mais interessantes. Essa é a divisão encontrada hoje entre a Ciência Literária e a real prática de leitura, não apenas da nova geração, mas de um contingente populacional que inflam vendas de livros ditos paraliteratura, como os de auto-ajuda.

Especialmente no ano de 2005, esse debate veio novamente à tona com força e ganhou destaque no espaço público devido ao Ano Ibero-americano do Livro e da Leitura conjugado, especialmente no Brasil, com a publicação de dados sobre a alta taxa de analfabetismo funcional.

Paralelamente a estas discussões, era criado no Fórum Permanente Interdisciplinar da Escola de Comunicações e Artes da USP o projeto de saraus de leitura de textos da coleção do São Paulo de Perfil - publicações narrativas de autoria de alunos de graduação, pós-graduação e da terceira idade, com temas do inventário da metrópole - em bibliotecas municipais (por conta das comemorações do aniversário da cidade) e com continuidade também em escolas públicas, em Centros Educacionais Unificados e em locais com iniciativas não-governamentais para alfabetização de adultos. A prática destes saraus, cujo maior objetivo era simplesmente dedicar um momento para a leitura, mostrava certo descompasso entre os dados quantitativos e qualitativos a respeito da prática da leitura. Embora o público-alvo dos saraus tivesse o perfil da categoria nomeada de não-leitores, com histórico de leitura restritivo em relação aos clássicos, há uma receptividade, identificação e o aparecimento de interesse imediato aos ensaios-reportagens presentes nos livros da série.

A reflexão epistemológica e pragmática a respeito do ato de ler sob a ótica da comunicação social levantou inquietudes diante da fragilidade dos conceitos que perceptivelmente não são suficientes para compreender a complexidade dos elementos sócio-culturais, econômicos, psíquicos e míticos envoltos no momento epifânico da leitura. Como definir literatura? Há livros bons em si? Todos devem apreciar o mesmo tipo de texto? Há uma qualidade estética objetiva nas obras? Existe uma maneira correta 
de ler literatura? Quais são as prerrogativas para a formação de um leitor? Porque há tantas incompreensões entre leituras legitimadas e leitura de consumo?

A realidade das leituras, sejam elas legitimadas ou não, trazem á Ciência a necessidade de pesquisas para se compreender o fenômeno. Nesta tentativa de compreensão surgem inquietações. Os estudos têm mostrado que a avaliação de uma obra depende de um conjunto de critérios e não unicamente da percepção da excelência do texto. Não há obras boas e ruins em definitivo. Há escolhas. Ler um livro é cotejá-lo com nossas convicções sobre tendências literárias, sobre paradigmas estéticos e sobre valores culturais. A excelência de textos nasce quando a leitura acontece no íntimo do leitor que a contrasta com suas idéias sobre ética, política, moral, com sua visão de mundo. A leitura, enquanto produção simbólica e também como arte, está inserida em sistemas culturais. Se o sistema cultural do senso comum (como define Boaventura) ou saber local (usado por Gertz) estão discrepantes do "intelectualmete desejável”, é porque o sistema cultural da Ciência, dos priveligiados, se distanciou de seu foco primordial, a realidade primeira, a dos acontecimentos sociais. Assim, para avaliar uma obra é preciso compreendê-la dentro do sistema de valores em que foi criada, seguindo os princípios de coerência da Teoria dos Sistemas.

E como a reflexão científica e este movimento de alteridade para compreender o fenômeno da leitura (compreender o gosto individual e as escolhas do que as pessoas leêm) encontram entraves para acontecer, também a escola não abre espaço para a discussão dos livros preferidos pelos alunos. Nesse sentido, a literatura erudita será entendida como um conjunto de produções realizadas por um determinado grupo cultural e não como a Literatura, assim como a visão do crítico literário expressa uma leitura e não a única leitura autorizada e legitimada. 
A fenomenologia da leitura é então aqui investigada através de uma revisão bibliográfica e de pesquisa laboratorial por meio de realizações de saraus de leitura, em escolas e bibliotecas, com narrativas das publicações da série São Paulo de Perfil.

Na busca bibliográfica, há uma consciência histórica que instiga a pesquisa por trabalhos e raízes antecessoras. Assim, não se pretende dar um desfecho e apresentar verdades. A metodologia é de interrogantes epistemológicas, de obra aberta e intertextualidade. Também se optou pela busca bibliográfica multidisciplinar, obtendo um quadro de leitura "multicorrentista", não se restringindo por este ou tal autor, esta ou tal corrente de pensamento, escola científica.

Os saraus condizem com a proposta metodológica de compreensão da identidade cultural e da realização de trabalho de grupo que irrigam, solidariamente, a Ciência com apelos coletivos e humanizantes. Além da afetuosidade entre sujeito-pesquisador e sujeito-pesquisado, o trabalho empírico propicia o laço humanizante também com o próprio objeto de estudo.

A redação do trabalho de pesquisa segue a metodologia de narrativa que conjuga as narrativas explicativa, descritiva, compreensiva e principalmente, a narrativa ensaística. Houve vários momentos de experimentação no processo de construção do trabalho científico em busca de intuição criativa capazes de dar marcas de autoria cultural e individual à pesquisa.

\section{Contextualização do tema}

Em 2004 e 2005, um assunto teve grande destaque na mídia brasileira e, de certa forma, na latino-americana. $\mathrm{O}$ destaque não foi devido a uma grande descoberta da mídia, pois o tema está longe de ser novidade, nem objetivando polemizar o assunto, embora muito ainda sobre a questão está por ser debatido. A pauta na agenda social dos povos latinos foi intencionalmente provocada por decisão política. Depois de décadas

com o rótulo de países subdesenvolvidos e de outros em (infindável, “ainda bem”) 
desenvolvimento, cientes da falta de políticas públicas para a educação, em 2003, a Cúpula dos Chefes de Estado dos Países Ibero-Americanos - diga-se bem: OEI (Organização dos Estados Ibero-americanos), Cerlalc (Centro Regional para o Fomento do Livro na América Latina e Caribe), Unesco e os governos - agendaram o Ano IberoAmericano da Leitura para 2005. Portanto, entre a idéia política e a ação, um intervalo de um ano para a preparação de projetos e de recursos, humanos e monetários. Estava pautada para os dois anos seguintes, 2004 e 2005, uma campanha de mobilização social de longo alcance com o objetivo centrado no incentivo à leitura.

Em 2004, as metas giravam em torno da inserção do tema na mídia, que se deu por meio de reportagens nas quais se contavam as histórias - exemplares - de personagens que tinham uma relação visceral com livros. Nesta linha de pensamento, a leitura como um ato admirável, foram feitos perfis de atores sociais como da pesquisadora e crítica literária Nelly Novaes Coelho, professora da pós-graduação em Literatura Portuguesa da Universidade de São Paulo, que, aos 82 anos (em 2004), acabara de receber uma notícia que seus netos haviam se comprometido em criar uma fundação para abrigar sua biblioteca particular: uma coleção de 10 mil livros, garimpados ao longo de cinco décadas de estudos nas áreas de literatura brasileira, portuguesa e infanto-juvenil . Ela era apenas uma das personagens que compunham, em matérias-perfis, aquela edição do suplemento especial do jornal Folha de S. Paulo, o caderno Sinapse. No mesmo caderno se encontram histórias como a de Evando dos Santos, sergipano de 40 anos, pedreiro por profissão e "herói" por possuir uma biblioteca particular de 40 mil livros, institucionalizada como Biblioteca Comunitária Tobias Barreto (seu autor preferido), localizada na Vila da Penha, Rio de Janeiro. No elenco dos amantes de livros e da leitura, não poderia estar ausente o bibliófilo José Mindlin. No mesmo caderno, entre dicas de como gostar de ler e dados sobre a leitura mundial, se anunciava o resultado de uma enquete virtual realizada com 1.216 
internautas, na qual os participantes deveriam associar o ato de ler a uma justificativa. Os votos dividiram-se na proporção de $1 \%$ como aborrecimento, $5 \%$ por obrigação, $7 \%$ como passatempo e $87 \%$ por prazer.

Os dados, que apareceriam em muitas reportagens no segundo semestre de 2004 e ao longo de 2005, tinham uma mesma origem: a publicação dos dados do Inaf (Indicador de Analfabetismo Funcional) de 2004. De acordo com a pesquisa, encomendada pelo Ministério da Educação, apenas 25\% dos brasileiros compreendem o que lêem. A pesquisa revelou índices apocalípticos. $\mathrm{O}$ mais esperado era o de analfabetismo, tido, de certa forma, como um medidor de avanço no país. No Brasil, este medidor somou 9\% da população com idade acima de 15 anos, ou seja, 16 milhões de pessoas inábeis ao ler ou escrever o próprio nome.

Analfabetos em nações "subdesenvolvidas" não é novidade. Nas décadas de 1960, 70 e 80, este era o grande problema social brasileiro. Como exemplo, podemos citar a criação do Mobral (Movimento Brasileiro de Alfabetização) em 1967, visando alfabetizar pessoas na faixa dos 12 a 35 anos e tendo como meta reduzir o analfabetismo para um nível residual de 5 a 10\%. A metodologia de alfabetização baseava-se - como ainda se baseia, apenas com nomenclaturas diferentes - em dois métodos principais, usados de forma combinada: o sintético ou, como é hoje chamado, fônico, que percorre o simples e prepara para o complexo, i.e., vai da letra e da sílaba para a palavra (daí o estereótipo de alfabetização através da soletração, do bê-á-bá, das associações repetidas, homófonas, homógrafas, do vovô-viu-a-ave); e o analítico ou, o que hoje chegou a se tornar modismo, o método construtivista que ensina blocos de palavras, sentenças inteiras, e a partir destas vai para os elementos formadores da frase.

Contudo, em 1980, o censo posterior ao início das atividades do Mobral registrou 32,7 milhões de analfabetos. O crescimento contínuo e acelerado da população, não somente no Brasil mas em todo o mundo, porém acentuadamente em 
regiões carentes, fez com que os esforços para erradicar o analfabetismo fossem insuficientes. Tanto que em 1985 o Mobral foi extinto.

A erradicação do analfabetismo é uma preocupação antiga dos governos e da sociedade internacional, como é o caso da Unesco, que, durante a $33^{\text {a }}$ Conferência Geral da Organização das Nações Unidas para a Educação, realizada em outubro de 2005, em Paris, lançou oficialmente a Iniciativa de Alfabetização para Empoderamento (cuja sigla em inglês é LIFE). Trata-se de uma estratégia de ação global para implementar a Década da Alfabetização das Nações Unidas e cumprir o quarto item da Declaração de Dakar (reduzir pela metade o analfabetismo entre adultos no mundo até 2015). O programa em desenvolvimento em 34 países cujas taxas de analfabetismo superam $50 \%$ da população ou atingem mais de dez milhões de pessoas. No Brasil, o projeto Década da Alfabetização já está em vigor.

O país de maior tradição contínua no campo da alfabetização de adultos é a Inglaterra, que possui políticas específicas desde 1790, quando abriu a primeira escola especializada, em Nottingham. Portanto, na nossa frente há mais de dois séculos. O programa britânico e o norte-americano, que se inspirou no primeiro, apóiam-se na iniciativa privada e em contribuições voluntárias (dinheiro, prestação de serviços). É comum o uso de clubes e associações já existentes em parceria com os programas de alfabetização e com ensino profissionalizante. Porém, as peculiaridades destes esforços estavam enraizadas no contexto social daquela época em que o conceito de alfabetização pressupunha "entender" e "se fazer entender" por escrito, ou seja, saber ler e escrever com suficiente desembaraço para fazer uso deste na vida diária. Esses dois objetivos principais são suficientes? Na abertura da Década da Alfabetização no Brasil, o orador Adama Ouane, diretor do Instituto de Educação da Unesco, órgão voltado para a alfabetização de pessoas com mais de 15 anos, confirmou que o Brasil precisa redefinir seus programas de alfabetização de jovens e adultos se quiser mudar a 
realidade do contingente de pessoas que ainda não sabem ler nem escrever. Embora o índice de analfabetismo tenha caído de $19,7 \%$ da população, em 1991, para 12,8\%, em 2000, houve uma estagnação desta caída. Em discurso, Ouane declarou:

Depois de chegar à média de $85 \%$ de alfabetização, os países em desenvolvimento têm mais dificuldade em atingir a parcela residual da população de analfabetos, e para lidar com esses $15 \%$, os programas padronizados não são mais tão eficientes e em seu lugar devem surgir programas alternativos, um para cada realidade.

Pelo fato de o analfabetismo ter, de certo modo, problema de caráter numérico que "mancha" a imagem do país, preocupando políticos e empresários (nãoexcludentes), em especial no Brasil - Cuba tem os menores índices de analfabetismo e mesmo assim "pinta-se" a ilha com "manchas"; ter ou não analfabetos não é primordial para a política de um país -, as iniciativas concentraram-se em objetivos que aumentassem a quantidade de pessoas que recebessem o ensino elementar "de primeiras letras" - decifrar as letras do alfabeto - e soubessem pelo menos assinar o próprio nome. Sem dúvida, estas ações contribuíram para maior acessibilidade ao conjunto de signos que formam o código linguístico (alfabeto). Mas até que ponto este acesso, este contato com o alfabeto, permitiu ao ser humano, recém-apresentado ao mundo das letras, ir além do receber e transmitir informações escritas por meio do código linguístico? Será que a leitura e a escrita o incluíram na sociedade, dando-lhe respaldo para se expressar com seu mundo exterior? Uma revisão do modo de pensar a leitura, à luz de paradigmas contemporâneos da comunicação social, como o Signo da Relação, questionaria se a escrita e a leitura são mesmo para se "entender" e "fazer-se entender", ou é uma forma de "ouvir o Outro" e "expressar-se ao Outro". Estas são perguntas que coloco nas questões do ensino da linguagem no século 21 e que levarei adiante no capítulo da Leitura como Comunicação Social. 
Quando foi divulgado, o Indicador de Analfabetismo Funcional gerou polêmica ao trazer à tona uma resposta em formato de números para as perguntas acima mencionadas: $50 \%$ dos brasileiros, metade da população, eram classificados como analfabetos funcionais, traduza-se: pessoas sem domínio pleno das habilidades de leitura e escrita, com dificuldades para assimilar as informações contidas em um texto e relacioná-las com outros dados. O resultado foi considerado alarmante porque avaliou uma população até então não contabilizada nos índices de desenvolvimento social do governo: as com escolaridade acima de oito anos.

A eficiência das metodologias de ensino no país, especialmente do ensino da língua, um dos motivos apontados para tais índices, foi a falta de hábito de leitura dos brasileiros. Considerava-se também, em alguns casos, com o perigo de ser um tiro no próprio pé, a ineficiência da metodologia do ensino no país.

De fato, várias pesquisas apontam que o brasileiro lê pouco. Conforme pesquisa encomendada em 2001 pela Câmara Brasileira do Livro e pelo Sindicato Nacional de Editores de Livro, 61\% dos brasileiros adultos alfabetizados não tem praticamente nenhum contato com livros, o que coloca "em cheque" a afirmação de que leitura e escolaridade estão proporcionalmente interligadas. De 1995 a 2003, o mercado editorial viu suas vendas caírem pela metade, além de uma redução de $13 \%$ no número de títulos e de $10 \%$ nos exemplares editados, segundo pesquisa do Grupo de Pesquisa em Economia do Entretenimento da UFRJ (Universidade Federal do Rio de Janeiro). As avaliações do Ensino Médio pelo Instituto Paulo Montenegro (repartição do Instituto Brasileiro de Opinião Pública e Estatística, Ibope) e pelo Censo Educacional do governo estadual não indicam uma reviravolta da tendência; a porcentagem dos chamados analfabetos funcionais não irá decair tão cedo, pois os alunos estão se formando com dificuldades de interpretação de texto. 
A tendência não se restringe, porém, aos povos "subdesenvolvidos"; se for um mal, é um mal mundial. Desde o final da década de 1970, quando a Unesco definiu o conceito de alfabetizado funcional, foi constatada uma estimativa de 900 milhões de analfabetos funcionais no mundo. Estes números são altos mesmo em países ricos e tradicionalmente envolvidos em projetos de alfabetização, como Estados Unidos e Inglaterra, o primeiro com $21 \%$, e o segundo com $22 \%$ da população nestas condições, de acordo com estudos publicados pela The Economist, em 2000. Dados conflitantes com o número de vendas em alta no mercado editorial: cada uma das 13 maiores editoras do mundo vendem, sozinhas, mais que a soma de todas as instaladas no Brasil. Conflitantes se pensarmos na medição da leitura de forma quantitativa e pelo número de livros vendidos. Logo, podemos questionar dois pontos: se o acesso aos livros é determinado pelo poder aquisitivo, e se, uma vez com o livro nas mãos, há interesse pela leitura. Um indivíduo com um livro na mão é um leitor?

Interesse pela leitura existe. Outra pesquisa, também de 2004, Retratos da Leitura no Brasil, enumera que $67 \%$ dos entrevistados demonstram interesse pela leitura. Retratos da Leitura é uma pesquisa qualitativa e foi feita em 40 cidades espalhadas por todas as regiões do país, com resultados que contrastam com os números das pesquisas quantitativas: $62 \%$ do contingente de pesquisados afirmam que gostam de ler, enquanto que $30 \%$ haviam lido um livro nos três últimos meses que antecederam a pesquisa, e $20 \%$ tinham lido pelo menos uma obra no último ano. Ainda que críticos questionem a práxis de um ato intencionado que apareçam em respostas de perguntas em pesquisas qualitativas, estas porcentagens, no mínimo, nos dizem que ler é tido como algo positivo e desejado.

Ainda assim, não há como negar que a carência de lugares dedicados à leitura influencia na contingência de leitores. Segundo a Câmara Brasileira do Livro (CBL), o Brasil tem a ínfima quantidade de 1.500 livrarias em todo o território nacional. Os 
municípios sem livraria incham um dado de $89 \%$. Mil e trezentas cidades não possuem biblioteca.

Podemos talvez dizer que, em matéria de leitura, há dois problemas distintos e complementares: ter o livro e ler o livro. Assim, de nada adiantará uma política federal de incentivo à leitura com medidas que pendam ao vazio, à estocagem de livros ou à mera distribuição de livros, ou à repetição de idéias estereotipadas a respeito da leitura.

As pesquisas científicas, o avanço da tecnologia e a inserção destas no cotidiano humano, provocaram mudanças substanciais na cultura e no jeito de pensar o mundo. $\mathrm{Na}$ atual conjuntura, apenas em situações especiais pode-se falar em leitura apenas do código linguístico, já que em muitos textos articulam-se diferentes linguagens. Este fator, que é contemporâneo, deve, de alguma forma, estar mudando o jeito de interagir com o mundo através da leitura. É um momento histórico a ser estudado para melhor se compreender a sociedade nos dias de hoje.

É flagrante a quantidade de informações, por inúmeros meios, que chega às pessoas. Para citar apenas uma consequência, isso afetou a forma de adquirimos conhecimento, ampliando as fontes de informação que antes decorriam quase exclusivamente da educação formal, institucionalizada na escola. Não se trata de qualificar se isto é benéfico ou prejudicial. Trata-se de um esforço de vislumbramos a História acontecendo sob nossos pés.

Por um lado, a quantidade de informações a que temos acesso pode provocar superficialidade de conhecimentos, o que nos leva a afirmar que a ação de ler é hoje uma tarefa bastante comprometida com seu tempo e restringi-la à linguagem verbal seria insuficiente para dar conta do emaranhado de conhecimentos que permeia a realidade. De outro ângulo, a quantidade de informações a qual podemos ter acesso pode ser encarada como um bom estímulo cerebral, exercitando nossas habilidades e 
conhecimentos, a fim de que, em um futuro próximo, possamos compreender melhor a complexidade dos fenômenos mundiais.

Bom ou ruim, a questão é: o que fazer com toda esta oferta de informações? Saber qualificá-las e selecioná-las é cada dia mais necessário. Outro desafio, em tantos que possam surgir, é aprender a inter-relacionar, procurar os nexos da realidade - que, apesar de sempre ter sido caótica, talvez agora estejamos enxergando melhor seus elementos de complexidade - e, a partir daí, com uma costura autoral, na condição de ser humano único, criar uma realidade simbólica totalmente alicerçada em tempos e espaços sociais múltiplos. A leitura e a escrita, sem esquecer-se do ato ontológico de contar, muito comum em povos de tradição oral e de populações ágrafas, são formas de tecer estes nexos, multiplicando simbolicamente as experiências sobre a realidade real.

Com o pensamento que a leitura e a escrita são realidades simbólicas de criação humana para fruição do próprio humano, algumas indagações surgem: existe leitura errada ou certa? Se há um desejo latente de ler mais, o que impede as pessoas de fazêlo? A leitura só pode ser apre(e)ndida na infância? Por que depois da tradicional alfabetização a leitura se torna uma atividade desprestigiada? Por que somos obrigados a ler os clássicos num período de amadurecimento no qual ainda não entendemos por que é importante ler os clássicos? As pessoas descobrem com facilidade o prazer de ler a TV, o jornal, a revista, o cinema, o gibi, a Internet; por que o livro não possui este prestígio e abrangência, se é que isso é fato?

O que pensar sobre o livro Harry Potter, um fenômeno de crítica e de público? Não é literatura? É um texto pobre, como pensam alguns professores? O bruxinho é uma má influência para as crianças, diriam algumas crenças ortodoxas, e os pais devem proibir o contato dos pequenos com esse tipo de leitura. Não é lugar comum pôr a culpa no sistema, relacionar o livro com religião? Em entrevistas na mídia, sociólogos, psicólogos e antropólogos dizem que a aproximação dos leitores com o livro se deu 
devido à falta de referências religiosas fortes que faz com que os brasileiros, em especial, se apeguem a misticismos, dentre eles Harry Potter. O fato é que as duas mil páginas da obra completa (seis livros), sem quaisquer ilustrações, foram vendidas para 270 milhões de pessoas no mundo, sendo dois milhões no Brasil. Livros vendidos e lidos. Numa conversa descomprometida com alguns destes milhões de fãs de Harry Porter percebe-se que mais do que compradores de livros, eles são leitores, citando trechos da saga do menino-bruxo como quem acompanha diariamente uma novela, fazendo relações e referências de um volume para o outro. Talvez a única conclusão a que possamos chegar a respeito de fenômenos como Harry Porter, O Senhor dos Anéis e O Código da Vinci - livros que se interceptam por todos terem versão cinematográfica - é a de que essas leituras não recebem o mesmo tratamento que as literárias obrigatórias nas escolas, para que o leitor fique a par do enredo da obra, uma vez que esta já é sabida ao se assistir o filme ou ler o livro, e vice-versa. Lê-se, sim, para fazer a trama acontecer linha a linha, página a página, capítulo a capítulo, volume a volume.

Assim como Harry Porter, por ocasião da oferta (quantidade de títulos) e da demanda (busca de autores "alternativos"), há dezenas de títulos "extra-oficiais", aqueles que não encabeçam a lista dos clássicos, presentes no repertório não só da juventude, mas de todos, brasileiros ou estrangeiros. Em palestra sobre os rumos da Literatura na Faculdade de Filosofia, Letras e Ciências Humanas da USP, em outubro de 2005, os depoimentos dos visitantes, alunos alemães de intercâmbio, anunciaram a preferência por autores desconhecidos por "não se mostrarem majestosamente maiores do que a minha realidade miserável de mero leitor". No livro Una Historia de la Lectura, Alberto Manguel narra experiência semelhante: aquella flamante sensación de libertad nunca nos abandonó, e incluso ahora, al disfrutar de un libro que cierto crítico há condenado o al desechar otro que há recebido cálidos elogios, me parece recordar com gran nitidez aquel sentimiento de rebeldía (MANGUEL, 2005: 168). 
Sob estas indagações, inquietudes e incertezas, este trabalho pretendeu mapear em que terreno estamos plantando os conceitos e noções a respeito da leitura, seja em discurso ou em processo (o signo em uso) e, assim, buscar compreensões possíveis para alguns diagnósticos sobre este tema, utilizando o paradigma contemporâneo da comunicação social, o Signo da Relação, que vê a sociedade em diálogo e trocas constantes.

\section{Do Signo da Relação}

Foi comum na literatura da comunicação social esquematizar o processo de comunicação como monológico e unidirecional. Acreditava- se que o emissor da mensagem era sujeito ativo e o receptor dela apenas passivo, tendo este como função receber e decodificar o significado contido na mensagem. Esse modelo, simplista, não corresponde à complexidade dos processos de comunicação. A vida social é multidimensional. Daí a proposta do Signo da Relação em substituição ao Difusionismo. Pois circulam no ambiente social bens que podem ter valores e significados distintos para cada indivíduo ou grupo, época e lugar. Esses fatos, bens e valores relevantes para a sociedade exigem que a linguagem e o sistema de mediação de significados intertextuais sejam igualmente multidimensionais. Conforme as relações individuais e sociais tornam-se mais complexas e amplas, a linguagem e o sistema de significados culturais precisam ser re-atualizados pelos mediadores sociais, os quais, através de suas narrativas sobre a realidade, recriam-na e dão estabilidade, mesmo que transitória, ao quadro geral de referências culturais vigentes em certo contexto. A linguagem e a comunicação em geral precisam ser diferentes para poderem ser compreendidas por pessoas diversas em contextos distintos. Por isto, a construção da narrativa, escrevendo ou lendo, embora com a marca de criação de seu autor, permanece inacabada, pois cada destinatário irá completá-la com base em seu respectivo sistema de valores e de signos. Sob esta perspectiva, investiga-se a leitura, tema desta tese. 


\section{Capítulo 1}

\section{Cruzeiro pelos Saraus}
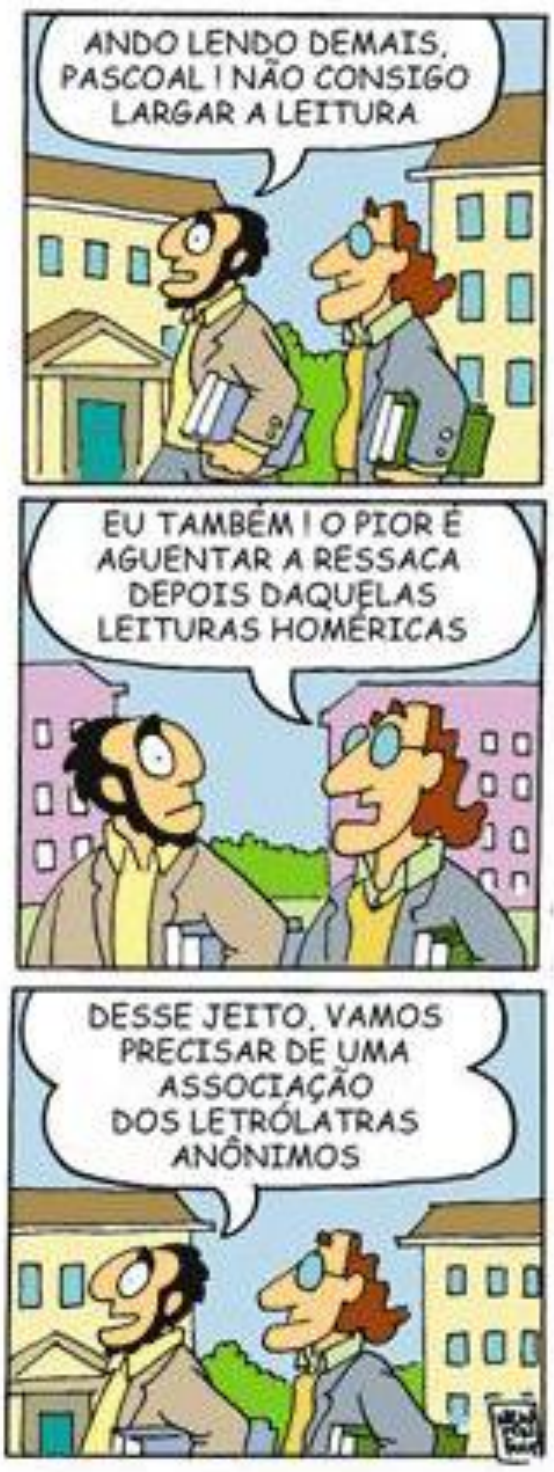

ESCOLA DE COMUNICAÇÕES E ARTES

Doutorado em Ciências da Comunicação

Teoria e Pesquisa em Comunicação 


\section{Capítulo 1}

\section{Leitura}

\section{Cruzeiro pelos Saraus}

Desde o último século, a humanidade tem se esmerado num esforço coletivo de alfabetização, no entanto a capacidade de leitura do sinal alfabético ganhou um significado no mundo contemporâneo restrito à condição de poder, esquecendo-se da condição de gozo e mágica da inexplicável necessidade imperiosa de ler e escrever. Quando se fala de indigência de leitura e fastio em escrever há de se considerar mais do que um problema de ordem educacional ou cultural. A apatia em relação à produção textual, tanto pela leitura quanto pela escrita, talvez esconda outras questões: da exclusão social, da não participação, da perda de capacidade de intervenção social que se manifesta também na leitura. A seguir, a leitura enquanto construção social em narrativas vivas, onde sujeitos, inclusive o sujeito-pesquisador, misturam-se e significam-se em saraus de leituras.

\section{Saraus by Izaura}

O grito de Marsilac nas brumas do Ipiranga

Meu pai tinha falecido, Na carta vinha dizendo, As terras que ele deixou, Minha mãe acabou perdendo, Para um grande fazendeiro, Que abusava dos pequenos, Meu sangue ferveu nas veias, Quando eu fiquei sabendo, Invadiram as terras minha, Tocaram a minha mãezinha, Pra roubar nossos terrenos, Eu voltei pra minha terra, Foi com dor no coração, Procurando meus direitos, Eu entrei no tabelião, Quase que também caía, Protegia os embrulhão, Me falou que o fazendeiro, Tinha rios de dinheiro, Pra gastar nesta questão.

A letra sertaneja de Lourival dos Santos e Moacyr dos Santos escolhidas por Marcelo

José Abreu Lopes, o escritor de As Brumas de Marsilac, uma das narrativas que compõe o 
oitavo livro da série São Paulo de Perfil, ganha interpretação declamada por uma voz forte e rouca que imita a vibração das cordas de uma viola. A letra vira poema e ecoa em um salão cheirando a pouco uso. Ali, as cadeiras de plástico verde ficam enclausuradas tendo companhia apenas o piso de tacos e as janelas gêmeas por onde timidamente a luz consegue entrar. Naquele dia, porém, além das portas-balcão abertas, algo diferente acontece naquele lugar, abarrotado de cadeiras em número muito maior do que as pessoas. Somos em oito, e nove quando o diretor da biblioteca, Genésio de Almeida Moura, faz toc toc toc no chão ao entrar esbaforido no anfiteatro: Me desculpem interromper, mas vim avisar que tenho compromisso e não posso ficar. O grupo presente demonstra pelas faces e bicos uma rixa de longa data como o espectador-relâmpago que nos deixa da mesma forma que encenou em sua aparição, com passos pesados e apressados que reverberam na madeira que compete com a voz, por mais forte e rouca que fosse. Voltamos a ser oito.

Ram, ram. Izaurinha limpa a garganta e engata a segunda marcha: Quilômetro 54 da estrada do capivari. Baixa a neblina na Serra do Mar. Dirijo meu carro. Viagem de exploração, rumo ao extremo sul que nunca chega. Essa estrada, aonde será que vai dar? E a curiosidade, superando o medo do desconhecido, empurra o repórter um pouco mais longe. Mas já não é mais possível chamar a estrada do Capivari de estrada. É um caminho de terra, em declive e com valas enormes. A passagem vai estreitando, logo logo não passará de simples picada no mato. Talvez seja melhor fazer um retorno agora do que nunca mais. Esquerda. Direita. Pra frente. Para trás. O corpo de Izaura baila com as palavras de manobras do carro e as pisadas nos tacos gritam para fora do salão, ultrapassam a madeira e invadem a caixa de cimento lá fora onde três atentos e concentrados leitores examinam livros tomando cuidado para não desfazer o remendo da capa, nem destacar as páginas amarronzadas do conjunto. Os olhares se voltam assustados para a origem do barulho. Lá dentro destaca-se uma figura de setenta e oito anos de experiência na brancura dos cabelos, num corpo pequeno, magro, aparentemente frágil, que não perdeu a leveza e a precisão. A vivacidade e a inquietude ficam por conta dos braços e dos olhos que fazem movimentos rítmicos. Nada os dizia que havia um evento especial, mas com certeza

aquilo era algo diferente. Somente hoje, com as portas-balcão escancaradas, o auditório se 
revelava aos frequentadores da biblioteca que descobriam que ali não era, como se especulava, um depósito de documentos sigilosos de um escritório administrativo impenetrável. Este desvendamento fez com dois deles desafiassem o batente da porta que poderia estar controlando os ingressos. Não havia ingressos, a sessão ainda estava no começo. Entraram e se somaram a nós: agora somos dez.

\section{Pare um pouquinho aí!}

Os dois jovens ressabiados, avermelham as bochechas, risadas no grupo, Izaura cai na gargalhada, eles se entreolham e sentam-se num sinal de positivo meu. Todos nos recompomos da divertida coincidência, e Izaura continua a leitura e explica aos jovens ainda com a face rosada, é o fotógrafo que está comigo quem pede. Ele aponta para um sítio na beira da estrada. Um grupo de crianças brinca na porteira. Presa a um poste, uma plaqueta: Sítio São José. No alto de uma colina, - o braço se estica apontando para o teto - a casa e, um pouco abaixo, - o braço agora se aproxima dos tacos - uma capela. Na frente, um lago com patos e cisnes. Junto à margem, um homem poda arbustos. Vale uma foto? É uma bela paisagem. O fotógrafo desce e bate algumas chapas. Rapidinho, antes que a neblina invada tudo. Pronto, vamos embora! Dou a partida no motor e arranco.

Olhos atentos à leitura. Todos já entraram na brincadeira, entenderam a proposta. Este seria o tal sarau de leitura que um grupo da Universidade de São Paulo vinha realizando nas bibliotecas municipais desde o início de 2004, com temas comemorativos aos 450 anos da cidade de São Paulo. A leitura radiofônica de Izaura conquista em minutos os meninos que há meses pelejam na tentativa de organizar um grupo amador de teatro e conquistar aquele espaço do auditório para ensaios e apresentações, sempre negadas pelo diretor, em suas palavras, cumpridor do seu dever de manter a ordem e a integridade do patrimônio público, o que para ele justifica, porque mantinha a sala trancafiada desde o seu mandato, segundo confidência dos meninos. Desse jeito não dá. Não andamos nem cem metros. A surpresa chega numa moto que vem detrás, toma a dianteira e fecha o caminho. Desce um sujeito truculento, o mesmo que podava arbustos. Boné na cabeça, barba rala, cara de poucas amizades. A camisa levantada na altura da cintura serve para deixar bem claro que está armado e, consequentemente, que é ele quem dá as ordens. Faz questão 
que vejamos seus dois facões. Izaura prepara uma pose de machão bruto, faz bico, força a garganta, comprime as bochechas, e finalmente sai uma voz engrossada: - O filme! Passa o filme pra cá! Tento alguma argumentação, mas o que dizer? - Quem deu autorização pra tirar foto? Aqui é propriedade particular. Passa o filme rápido! Não há outra saída. Izaura acelera o fraseado no mesmo ritmo do desespero do protagonista. Abro a câmera, corto o filme, retiro a parte usada e a entrego ao sujeito.

- Agora cai fora! Ele tira a sua moto da frente e nós podemos andar outra vez. O brutamonte fica nos vigiando de longe. O susto vai passando, mas não acabaria aí. Novamente não andamos cem metros, o sujeito voltou a repetir a cena. Nova parada forçada. - A câmera!

Fazendo cara de desolação: - A câmera não! - foi meu primeiro impulso. Os gestos para a voz engrossada se repetem: - Me dá a câmera. O filme. O tom muda drasticamente bem baixinho, quase engasgado, e até um pouco meloso: - Mas eu já dei o filme. - Me dá o resto! Opa, é outra personagem. Izaura volta na postura que criara para o sujeito, refaz os gestos, imita a voz grossa e repete a fala. - Me dá o resto! Agora sim o protagonista-narrador: (Para que ele iria querer o resto? Não foi usado). E numa cena surrealista, paro tudo para the explicar como a câmera funciona, e que ele pode ficar tranquilo, que o resto do filme não está usado, que o filme gira da esquerda para direita, que já íamos embo... - Deixa de conversa e me dá o filme. Izaura bate no taco novamente, pois a voz grossa não seria suficiente para encenar o momento tenso e a brutalidade daquele sujeito. Todos assustam com o barulho do movimento inesperado. Entre um meio sorriso de Izaura, a história continua: Abro a câmera e, com raiva, pego o filme por uma ponta e o puxo todo para fora do rolo, velando-o e o entrego pela janela. - Cai fora! Sei muito bem quem vocês são. Ah é? E quem somos nós? O sujeito nos encara por instantes, frações de segundo. O brilho de seus olhos são duas faíscas. Os pequenos olhos de Izaura parecem dobrar o tamanho. Esbugalhados não param de lacrimejar, o que os faz brilhar, não como faíscas, mas como estrelas. Desde que conheci Izaura suas duas bolinhas pretas vivem umedecidas, e gota por gota, esvaem-se pelas bordas, escorrendo como lágrimas. Quando a percebo lutando contra aquela aguinha persistente, e eu já não posso mais ignorar tanto o riacho 
que jorra dos olhos de minha amiga (já irritada), brinco perguntando que amor a faz chorar tanto, e ela, sorrindo, me responde, que é problema de junta - junta tudo e joga fora - ou que é para eu não ligar, porque no fundo no fundo, tudo aquilo são lágrimas de crocodilo e que tudo faz parte de uma cena para me comover e limpa os olhos, mais uma vez, com um lenço de tecido.

- Vocês são da Justiça, eu sei...

- Da Justiça?

- Vocês sabem que estas terras estão na Justiça e vieram aqui fotografar.

- Ninguém aqui é da Justiça. Só estamos fazendo um trabalho e...

- Agora cai fora e não aparece mais aqui! - cortou o diálogo e deixou bem claro no ar que, se aparecêssemos, não nos deixaria mais voltar. Então, o sujeito abriu de novo o caminho e nós deixamos a estrada do Capivari, voltando para o "centro" do vilarejo de Engenheiro Marsilac.

Silêncio na biblioteca. Silêncio absoluto no salão. O clima de tensão traçado pelo diálogo, o tom de discussão, todos estão solidários ao rapazinho que acabara de perder sua máquina para aquele homem bruto e ignorante que acabáramos de ver encarnado no corpo frágil de Izaura, e que ela faz questão de exorcizar com alguns segundos de silêncio para então retomar a história, num tom de voz suave, calmo, compassado. Estrada do Marsilac, km 52. Ponto final da linha da CMTC Santo Amaro/Engenheiro Marsilac. A praça da Sé está, pelo menos, a uns $60 \mathrm{~km}$ daqui. Difícil acreditar que ambos os lugares pertencem à mesma cidade. $\mathrm{A}$ Sé, símbolo de São Paulo, com seus chafarizes, mendigos, vendedores, meninos de rua, caros, semáforos, fumaça, ônibus e metrô. Engenheiro Marsilac, um lugar que nem consta nas plantas da cidade, com suas estradas de terra batida, casas de madeira, cachoeiras, cercas, plantações, cavalos, patos, galinhas, pinheiros e eucaliptos. Dois lugares tão diferentes, mas também tão parecidos, com os mesmos problemas de transporte, saúde, educação e segurança. Cof, cof, cof. E, no caso de Marsilac e região, a luta pela terra. É a face rural de São Paulo, uma cidade desigual que assim sintetiza um país chamado Brasil. Marsilac dista, depois de Parelheiros, 14 
quilômetros. É a vila mais remota da Zona Sul a que se pode chegar de ônibus. Dali para baixo não tem mais condução. Não é o povoado mais extremo. Existem outros, como a Ponte Alta, que faz divisa com Itanhanhém, opa, Izaura sorri do erro usual por conta da sonoridade da palavra de origem indígena. Faz divisa com Itanhaém. Porém de difícil acesso. As estradas são muito irregulares, tornando a viagem, mesmo de carro, quase impossível. Nem mesmo o pessoal da Administração Regional soube explicar direito como chegar lá ou como é o local. São só fazendas, talvez. Mas, no mapa, está indicada uma escola de primeiro grau. As fazendas realmente são muitas. Várias pertencem a empresas, como a Viação Cometa. Boa parte da terra está marcada como sendo Parque do Estado. O Reservatório de Capivari, da Sabesp, também ocupa um bom pedaço. Ademais, o que ali existe e acontece é do mais completo desconhecimento. Cof, cof. Ram. Izaura tenta limpar a garganta da saliva excessiva. A origem, não só de Marsilac, mas de todos os povoados da região de Parelheiros, como Embura, Jardim das Fontes, Colônia, Barragem, Cipó - cof, cof, cof, Izaura pede um copo de água e com a voz embargada prossegue: A origem, não só de Marsilac, mas de todos os povoados da região de Parelheiros, como Embura, Jardim das Fontes, Colônia, Barragem, Cipó e outros, remonta os fins do século passado, quando o Imperador D. Pedro II cedeu aquelas terras para serem colonizadas pelos imigrantes alemães. Com efeito, é comum encontrar ainda muitas pessoas loiras e com os olhos azuis, embora, hoje, os caboclos sejam maioria. Cof, cof, cof, cof. Posteriormente, chegaram os já... ram, ram... po-ne-ses...ram, ram; o copo de água está ao seu lado, acompanhado de uma jarra repleta, mas Izaura faz questão de terminar a frase...japoneses da Cooperativa Agrícola de Cotia, e o povo nissei também pode ser facilmente encontrado.

Pausa para refrescar a garganta.

Como o sarau de leitura foi na biblioteca municipal de Pinheiros, Biblioteca Pública Alceu Amoroso Lima, o nascimento destes encontros sociais em torno de vontade de dedicar um momento, depois de um dia cheio, com estudo, trabalho e loucuras de uma metrópole - trânsito parado, percalços no transporte público, assaltos e todas surpresas 
que o caos nos proporciona. Com exatidão, mesmo eu não sei onde e quando surgiu a idéia de partilha coletiva do intimismo da leitura, ou seja, as questões da representação do leitor. Pensando no conceito, talvez os saraus de leitura tenham aparecido em minha vida nos primeiros anos da minha alfabetização, antes do aprendizado propriamente dito, quando, curiosa para saber se o que eu lia nas figuras das dezenas de livros que chegavam todos os meses em casa - meus pais compraram coleções de enciclopédias diversificadas, sensibilizados pelo argumento dos vendedores, seus filhos precisam para os estudos - era o mesmo estava escrito lá, preenchendo o restante das páginas. A cada investida com pessoas diferentes da família, a leitura era uma, e, portanto, tinha o sentimento de nunca saber o que estava realmente escrito, um dos motivos, além de ser a caçula e a única que não ia para a escola, que aumentava dentro de mim a vontade e a curiosidade de ler e escrever. Quando aconteceu, continuei compartilhando minhas leituras, ora com meus irmãos, outrora com a mãe, a avó, e às vezes, com as bonecas. A leitura em voz alta era uma forma de expor ao mundo que finalmente eu aprendera a desvendar os códigos secretos da pequena biblioteca formada em minha casa. Ou grande. A novidade era tamanha, e ainda que todos os livros coubessem em uma única estante de quatro prateleiras, a aquisição valia a pena o investimento. $\mathrm{O}$ acervo pouco se renovava, justificável porque os títulos tinham um intuito de pesquisa escolar, por isso relia incansavelmente as coleções infantis, que sob muito protesto da mãe, com um desconto amigo do vendedor, haviam sido incorporadas, até mesmo na decoração da sala, à grande-pequena biblioteca familiar de minha casa. Desenvolvi uma boa dicção e uma fluência. Por pedido dos professores, todos os dias ia à frente dos meus colegas, em pé, e lia a meditação do dia, geralmente uma história sinteticamente contada em uma página do livro Meditações, próprio da escola Adventista. Estes foram nossos únicos momentos de leitura conjunta, da leitura manifesta. É claro que o pedido de leitura silenciosa era constante, mas os pensamentos aleatórios sempre venciam a tentativa de disciplinar o cérebro para atentar ao texto. Em casa, liberta das vigilâncias - quando não era o olhar do professor, algum aluno, geralmente o que tirava a melhor nota - meu treinamento de disciplinar-me para a leitura acontecia assim, de forma compartilhada, 
na maioria das vezes em voz alta e sempre de uma forma dialógica - eu sempre procurando um interlocutor. Até as diaristas - o fluxo sempre fora constante tornavam-se meus alvos. Me ouviam. Umas à contragosto delas próprias, e outras de minha mãe, pois muitas vezes fizera elas se atrasarem por pararem o serviço da casa quando minha leitura despertava algum interesse. Finalmente, para o alívio de muitos, comecei a valorizar a privacidade de uma leitura silenciosa quando me iniciei nos "assuntos para adultos".

A brincadeira de realizar leituras em grupo - não necessariamente em voz alta, mas essencialmente coletiva e conjunta, torna-se sarau de leitura após alguns meses de tomar conhecimento, como aluna da disciplina Narrativas da Contemporaneidade, da coleção São Paulo de Perfil. Alguns fatores contribuíam para que minha aproximação à série de livros-reportagem fosse além das apresentações. Em 2001, assistindo a aula da professora Cremilda Medina, fui convidada a substituir a bolsista do CNPq do projeto e finalizar a vigésima quarta publicação, uma homenagem aos 90 anos do Complexo das Clínicas, prestigiado no ano seguinte com uma menção honrosa no $10^{\circ}$ Simpósio Internacional de Iniciação Científica da Universidade de São Paulo. Em 2003, 90 Anos de Medicina e Vida representa, em Recife, no 50 Reunião da Sociedade Brasileira para o Progresso da Ciência (SBPC), a iniciação científica da Escola de Comunicações e Artes e da Universidade de São Paulo.

Produzir, editar, publicar livros é o óbvio do projeto. Com mil exemplares impressos a cada número, a coleção possui edições esgotadas e mesmo uma reedição. Embora com um fluxo considerável de saídas - vendas (o projeto tenta ser autosustentável), doações e usos pedagógicos - a inquietação durante o período em que permaneço no Fórum Permanente Interdisciplinar é da ordem de espaços. Especificamente, o físico, de dimensões da sala da professora no Departamento de Jornalismo e Editoração. O espaço conceitual, de encontros interdisciplinares e interdepartamentais entre docentes e discentes da graduação, pós-graduação e da Universidade Aberta à Terceira Idade em três projetos acadêmicos, além do São Paulo de Perfil, o Novo Pacto da Ciência e o Reproposta, supera os limites espaciais concretos 
e sempre acontece. Em outras palavras, de repente aquele amontoado de livros parados, guardados em prateleiras tornara-se um incômodo. E não se tratava de retomar iniciativas do Fórum de doações de livros para penitenciárias e FEBEM (Fundação Estadual para o Bem-Estar do Menor), e intensificar a distribuição em escolas e bibliotecas públicas. Havia de ser mais.

Glub, glub, glub. Uma copada de água. Onde estávamos? Ah, nos japoneses. Oh! Ra, ra, ra. Ainda bem que não tem menor de idade aqui. Em frente moçada.

Quem é o dono do quê ainda é uma pergunta que se faz na região. É verdade que, durante o caminho pela estrada do Marsilac afora, o que mais se vê são cercas. Mas também é verdade que grande parte dos loteamentos são ilegais. A briga entre posseiros e grileiros existe e já matou muita gente. A própria Prefeitura sabe disso. Mas o que se pode fazer, dizem eles. É impossível fiscalizar...

Algum dos interlocutores sussurra ao meu lado o pedaço de um pensamento: MST, semterras. Izaura não ouve, ou faz de conta que. O processo de discriminação de posse das terras da região começou na década de 30 . Vocês nem tinham nascido, nem eram projetos de gente ainda, nem mesmo eu... não me olha assim, Izaura dirige-se com cara de bronca a um interlocutor invisível, tá pensando que sou velha, é. A gargalhada é inevitável, porém ela não dá tempo para estas se estendam, e emenda a voz dela com os sons das risada, O processo de discriminação de posse das terras da região começou na década de 30. Mas é tão demorado que até hoje não terminou. De lá para cá, muita coisa mudou. O sussurro se repete: ...MST. Terras foram abandonadas, novos posseiros apareceram, lotes foram vendidos e vários foram roubados através das manobras mais incríveis, arranjando-se papéis falsos, falsas escrituras e toda a sorte de acordos verbais de jagunços para despejar os relutantes. Os posseiros, que na sua maioria desconheciam a língua dos advogados, foram praticamente expulsos de suas terras por grileiros mais espertos que, dizendo sempre que estavam com a lei e a polícia do lado, iam cada vez mais ampliando domínios territoriais. Para se obter um título de posse de governo, é necessário ter algum beneficiamento sobre as terras. Uma das artimanhas mais 
usadas é o arrendamento. Trata-se de um contrato de aluguel das terras por tempo determinado com a seguinte condição: todos os benefícios realizados por inquilino ficam posteriormente para o proprietário, que assim não precisa construir e nem plantar nada para ocupar o local.

Novamente, o mesmo sussurro, porém não mais em tom de afirmação. MST?

Como quem entra na arena de um rodeio. Peraí. Não foi assim que ensaiei. Como faz um locutor de rodeio? Lá trás, no grupo de atores amadores, um responde, Seguuura peão, e a explosão de risadas é inevitável. Inspirada, Izaura reinicia. Como quem entra na arena de um rodeio, pego as rédeas do volante e cheeeeego o reio. Se de longe alguém me escuta buzinar beeem alto, sabe que ali vai um cowboy do asfalto. O inspirador completa, iiiiiiiiiruu. Obrigada, pela ajuda. Vi que fazer isso não é fácil. Ah, quem escreveu isso foi Joel Marques, tá aqui no texto. Ficou tão horrível minha locução. Acho que isso é uma letra de música, viu. Eu não erraria. Ra, ra, ra. Mas nosso querido autor, o Marcelo, colocou isso aqui como um respiro no texto, então eu tenho direito de tomar mais um golinho de água, por favor, obrigada. Viramos a página e, Sábado de sol na estrada do Marsilac, que começa em Parelheiros. O ônibus da CMTC avança e vai resistindo bem aos buracos da pista. Uma melancia, escapulida de não sei qual sacola, rola pelo corredor e por debaixo dos bancos. Nossa, imaginaram uma melancia atropelando vocês dentro de um ônibus. Ao meu lado está Abrão. Izaura, sentada no degrau entre o chão de tacos e o palco aponta para um assento à sua direita. Trabalha em Santo Amaro e está vindo do serviço. Segue o tempo todo conversando sobre filosofia de vida. Mora em Embura há seis meses. Comprou um sítio por lá. Com a mão direita no canto da boca, como que a confidenciar um segredo, Mas um dia ele quer vender e ir para um lugar melhor. Embura é muito isolado, diz. Mas não é um lugar tranquilo? É, Izaura faz uma cara terrivelmente desolada, mas esse ônibus demora tanto para chegar lá. Embura é uma vila que fica cinco quilômetros antes de Marsilac e, de Santo Amaro até lá, não se faz em menos de hora e meia. 0 ônibus pode demorar até duas horas para passar. Isso, é claro, se não quebrar nenhum no meio do caminho. A estrada do Marsilac é conhecida popularmente como a estrada das Sete Curvas. Elas realmente existem e formam uma sequência em 
praticamente em ângulo reto. Hã. Opa, pulei uma linha. Os olhos não ajudam mais. Ela os seca com um lenço. Formam uma sequência em declive, ela soletra, para a esquerda e para a direita, seu braço direito vira uma cobra em movimento, todas fechando praticamente em ângulo reto. É um ponto perigoso, não permite ultrapassagem. O jeito é ter paciência com a lentidão do caminhão carregado de toras de madeira que segue à frente do caminhão... de novo... à frente do ônibus. Os grandes proprietários, além de plantarem cercas, costumam também extrair pinheiros e eucaliptos para lenha. Tá vendo este caminhão aí? - pergunta Abrão e aponta Izaura com o reto em riste para frente - É tudo carregamento ilegal. Só circulam de sábado, domingo e feriado. Eles desmatam e ninguém fiscaliza. Diminui o volume da voz, E se você for ver, esses carregamentos nem nota fiscal têm.

Bem no meio de uma das curvas, passamos em frente ao Clube dos funcionários da Kibon. Logo adiante, propriedade do Banco Sudameris. E então vem uma reta e o ônibus pode realizar a tão esperada ultrapassagem. Embura, agora, está próximo. Abrão se despede para logo descer. Com mais meia hora se chega à Marsilac. Mas o caminho ainda reservaria mais curiosidades. Do lado esquerdo, uma ruazinha de terra. $\mathrm{Na}$ estrada, uma cerca com uma pequena passagem, como se fosse uma porteira. Margeando a rua aparentemente particular, postos de iluminação pública! Uau.

Essa história puxa outra, Izaurinha se ajeita no degrau que virou banco e retoma o tom de era uma vez, há muitos e muitos anos. Em 1976, Jorge Falleti, um dos grandes proprietários da região, mandou seus jagunços fecharem uma estrada que dava acesso a um internato. Falleti dizia que era dono da estrada e resolveu trocar o direito de passar por ela por votos para o, na época, candidato José Maria Marin.

Fomos nós que arrumamos a estrada, quase grita, agora, vocês têm que votar no Marin - era um caminho estreito e de terra que, em dias de chuva, ficava quase intransitável. Os homens de Falleti ameaçavam, o dedo indicador de Izaura se levanta ao máximo - do polegar ao mindinho ela possui o limite nas articulações que imagine ser artrose - e a voz engrossa: Essa estrada é nossa, é particular. Se não votarem, não deixamos ninguém passar. Com um tom de confidência, ela vai ao parágrafo da 
explicação, Tudo começou quando as pessoas que visitavam o internato deixaram de aparecer porque era impossível fazer com que os carros chegassem lá. Os homens de Falleti ficaram de consertar a estrada. Mas ela continuou do mesmo jeito, e então pediu à Prefeitura que fizesse reparos. Certo dia, as máquinas surgiram. Os reparos foram feitos e as crianças internadas passaram a receber visitas regularmente, e todos viveram felizes para sempre, e isso não está escrito aqui. O que está escrito aqui é o seguinte Logo em seguida vieram os homens da Falleti ameaçando. Houve resistência e a estrada nunca foi fechada. Izaura engole em seco, procura o copo de água, mais um golinho, a mucosidade escassa, proveniente mais de seu hábito fumante do que da idade, não ajuda. O que falta na boca, escorre pelos olhos; ela não pára de limpar aquilo que já apelidamos de lágrimas de crocodilo.

O ônibus segue. De repente, um viaduto. A estrada passa por baixo da linha férrea que vai até Santos. Vem passando um cargueiro. As crianças fazem festa, se penduram nas janelas para ver o trem apitar. A estrada corre um trecho ao lado dos trilhos. E, quinhentos metros depois, estamos em Marsilac, finalmente, porque agora o autor coloca mais uma paradinha, um versinho, e antes de eu ler para vocês, eu vou pedir licença para dar beber minha água. Ram, ram, ram, ram. Pigarro teimoso se embaraça todo na garganta dela. Esperamos atentos a retomada que não demora e vem em grande estilo, com a Izaura cantora. Armei uma arapuca na beira da estrada, pra pegar moça bonita e também mulher casada. Apontando para espaços vazios e sugerindo um cenário imaginário, Uma pracinha com alguns bancos, dois coqueiros e o abrigo do ônibus. É o ponto final, junto à rua principal. À primeira vista, a vila se resume em uma dezena de casas daquela rua. É um exagero, mas nem tanto. Não existem muito mais ruas em Marsilac. As casas são simples e velhas. Deixam a impressão de que são as mesmas há décadas. Aliás, não são só as casas. Você olha para Marsilac e tem a nítida impressão de que se parou no tempo. Praticamente não há comércio. Três bares e um empório. O maiorzinho é o Lanches Cláudio. Fica bem em frente à praça. Som ambiente, bilhar, pebolim e mesinhas. Começo por ali. Fazem lanches? Izaura abaixa a voz em meio tom, não senhor, não fazemos. Segundos de silêncio para reflexão. De zero a 
dez segundos, Izaura produz pelo menos doze combinações de caras e bocas, da interrogação, surpresa e sarcasmo até sobressair o humor. É o autor quem explica a piada, e Izaura o obedece, Lanches Cláudio não vende lanches. Então me vê só um guaraná.

Tem um casal jogando bilhar. Fico observando o jogo, as pessoas. Encostado à porta tem um sujeito de cara feia, enruga a testa e tranca os lábios, Esse deve ser jagunço. A tentativa de voz grossa que faz biquinho, - Vai uma partida ai?, normaliza o rosto, e o tal sujeito me chamou para tomarmos lugar à mesa de bilhar, que acabara de ser desocupada. Surpreso com o convite, aceitei.

- Bichim, Izaura lhe dá um fraseado nordestino típico dá nova forma ao sujeito de cara feia, e ele se torna mais simpático, me dá uma ficha aí.

Pegou a ficha, abriu a gaveta e retirou as bolas.

- Que cor você quer?

Escolhi as azuis, como sempre. Meu adversário ficou com as vermelhas.

- Sabe, não sou muito bom não. O ritmo se arrasta para um sotaque bem baiano. Faz muito tempo que eu não jogo isso. É só de vez em quando, de brincadeira. Não jogo por dinheiro não.

- É, arredio e seco, eu também não jogo há muito tempo.

Dei a saída. O cara matou uma bola logo na primeira, abriu um sorriso maroto. Matei três em seguida, o sorriso dele foi embora. Agora é o sorriso de Izaura que se torna maroto. Faltava só mais uma, a fala se torna um suspiro baixinho, E se eu ganhar, será que ele vai ficar muito zangado? Será que ele não gosta de perder?

Errei a jogada seguinte e minhas bolas ficaram em posição ideal para que ele as matasse, uma a uma. Foi o que aconteceu.

- Vamos mais uma?

Perdi outra. E outra. E mais outra.

- Quer outra?

Não, chega. Hoje não é um bom dia. Pedi um novo guaraná. Quer beber alguma coisa?

- Me vê um refrigerante, também. 


\section{- Como é seu nome?}

- Guilherme. Mas pode me chamar de Bahia. Aqui todo mundo me conhece desse jeito.

Guilherme, baiano de Itapicuru, perto de Salvador. O passado dele é rápido. Abandonou um casamento com filhos e tudo e veio para São Paulo. Com sotaque, Eu aprontei né, e me fez um sinal característico com as mãos, ela se atenta a ler, nenhum gesto, aí tive que casar. Depois me cansei e dei um pé nela. Quando cheguei aqui o pessoal me olhava desconfiado. Pensavam que eu era grileiro, que eu era jagunço. Aí eu falei: eu não sou nada disso não. Eu vim em paz. Só quero trabalhar e mais nada.

- E o que você faz?

- Eu? Eu faço de tudo. Corto lenha, limpo terreno, planto, colho, sou pedreiro, pintor, encanador. Faço qualquer coisa. Agora eu tô trabalhando aqui na Sabesp de Capivari, tirando terra...

Entrou no bar uma garota bonitinha e Guilherme logo foi pregando o olho:

- GOSTOSA ela heim, acentua na palavra gostosa, Coisa boa aqui são as mulheres. Eu cheguei a amigar aqui. Mas ela me roubou todo o dinheiro e eu a mandei embora. Agora, mulher aqui é o que não falta. Sempre que eu preciso, tem. Se você quiser, é só chegar e pronto.

Risos.

Sorrisos.

Guilherme me mostra os dentes que não tem.

Não deu para reparar muito rosto a rosto, mas todos ali mostraram um fundo branco por trás dos lábios.

Depois, ficamos calados, olhando por instantes para o que acontecia no bar e na rua. Fazia um sol incrível, a temperatura beirava os quarenta graus. O céu era um azul só, promessa de tempo bom para o resto do dia. Faço um convite a Bahia. Será que ele poderia me mostrar a vila? Uma sutil mudança de tom, Pois não, vamos lá, o que você quer ver? O sotaque é esquecido. O jogo de tonalidades de vozes personalizadas, do narrador e do Bahia, continua, Você é o guia, você é quem decide. Então, vamos.... 
Pago a conta e logo saímos para um passeio turístico em Marsilac. Cruzamos com um grupo de rapazes vestidos só de calção e com o corpo molhado. Bahia acena para eles:

- E aí, como é que tava a cachoeira?

- Tava ótima.

Guilherme me conta então das muitas cachoeiras que existem ali e que descem a Serra do Mar. Quando o calor aperta, todos vão tomar banho nelas.

Subimos por uma rua de terra toda esburacada. Bahia me aponta uma das primeiras casas, à esquerda. Ela está em reforma.

- Essa casa é de um português que é um dos caras mais ricos daqui. Tá cheio de terras. Eu já trabalhei pra ele durante um ano. Tava combinado dele me pagar tudo quando eu terminasse o serviço. Mas ele não me pagou até hoje.

Bahia faz uma pausa e rumina sua indignação com o português. Depois continua:

- Sabe, ele já roubou muita gente por aqui. Eu chamei um outro cara aí e a gente ia matar ele. Só que o desgraçado anda sumido, não se sabe onde. Mas pode deixar que um dia a gente acha...

Passamos pela escola. A placa da obra ainda está lá: Governo Montoro. Na próxima esquina está a Igreja. Construção simples, pequena, daria mais uma capela. Parece abandonada. As armações de madeira das barracas da última festa ainda estão lá. A própria comunidade organiza e, fora isso, não há muito mais diversão em Marsilac.

Vamos até o campo de futebol. Subimos mais uns vinte metros. Aí está ele. Armações de barracas nas laterais. Quando tem jogo, vendem cerveja, caipirinha, churrasquinho. Hummmm, que delícia.

É Bahia quem conta: O time daqui nunca perde pra ninguém, todo mundo respeita. Na hora do jogo, aos domingos, a mulherada vem toda pra cá fazer torcida. Mas esse Bahia é mesmo um mulherengo. 
O sol permanece forte e então nos sentamos sobre um tronco, numa sombra agradável. Bahia continua a falar de Marsilac: Aqui, sempre acontece alguma coisa, somos nós que fazemos. Somos nós que juntamos o dinheiro. A gente que constrói as coisas.

- Aqui tem posto de saúde?

- Tem não. Não tem médico - o sotaque reaparece - Isso que é ruim. Já morreu tanta criança porque não tem remédio. Quando tem alguém doente ou morto, o transtorno é sempre o mesmo: ligar para Parelheiros e pedir para virem buscar. São 14 quilômetros de uma imensidão sem fim...

Este texto também tem uma imensidão sem fim. Alguém está cansado. Este garoto de camiseta está quase fechando os olhos. Está chato? Ah, todos vocês estão de camiseta. Ra, ra, ra. O do meio. Isso. Quer fazer um break? Não senhora, estou imaginando como é Marsilac. Então esta parte a seguir você vai gostar. Vamos lá.

Aqui tem terra que não acaba mais. Tá vendo ali atrás? Aquelas terras vão do Capivari até Embura, e são todas de um dono só. Ali no alto do campo de futebol de Marsilac, se pode ter uma visão panorâmica da região. Num ponto ou outro, a marca da destruição: clareiras provocadas pelo desmatamento.

- Morre muita gente brigando pela terra?

- Antigamente morria. Hoje, não, é mais tranquilo. Antes, sim, era boca quente. Agora, só de vez em quando aparece um caso.

A hora avança, a fome aperta e manifesto a intenção de comer alguma coisa. Guilherme já almoçou, diz que comeu carne de tatu.

- Carne de tatu? A ênfase interrogativa do autor e agora de Izaura é compartilhada com a cara de cada um de nós. Argh.

- É, você nunca comeu, não? É uma delícia, e faz um bem, ó!

Bahia passa a me ensinar como caçar um tatu, que ali tem muito. É preciso armar a arapuca com cuidado e depois, na hora de matar, Ter muita habilidade para não deixar o bicho escapar. Tem que colocar o facão nos pescoço dele e então....puk! Izaura faz um movimento brusco com a mão direita, de cima pra baixo, caçando, com um golpe 
certeiro, o tatu imaginário que acaba de passar pelo salão da biblioteca. Uma batidinha como martelo em cima dele e o tatu já cai de lado.Carne de cobra também é boa.

- Tem muita cobra aqui?

- Se tem? Pô, e como. Tem muita jararaca.

- Você já matou alguma?

- Se já matei? As folhas xerocadas do texto que foram aumentadas do original a fim de facilitar as coisas para a Izaura, saem da frente do seu rosto para mostrar o peito estufado e um trejeito galante. Ah, pra lá de quinhentos. Dava para encher um caminhão...

Um "nossa" audível e sarcástico ecoa por entre os tacos do chão e encontram a saída pelas tímidas janelas, pois a porta-balcão está fechada. Meio-sorrisos.

Izaura apressa em manter o clima.

- Mas elas andam pela vila?

- Quando tá frio, elas saem pra caçar. No calor, assim, elas ficam enroladas embaixo dos troncos e das folhagens.

Quer dizer, pode estar cheio delas aqui em volta, e aponta em nossa direção, embaixo das cadeiras de plástico. Re, re, re. Calma. Não tem cobras aqui. Essa frase está escrito aqui no texto do Marcelo, entre parênteses, como se fosse um pensamento seu.

Bom tá na hora de ir. Eu não. É o texto que fala isso. Bom tá na hora de ir, mas antes quero saber de Bahia se ele conhece alguém que more ali há bastante tempo. $O$ mais antigo aqui? Você tem que falar com a vó Ana. Ela benze as crianças daqui. Não falha uma. Vem que eu te mostro onde fica. E pra chegar lá cortamos caminho por uma picada já no meio da mata. Será que tem cobra aqui?

Ele fez mais uma pausa aqui com uma música, então eu também tenho direito. Secretária, Izaura dirige-se à sua acompanhante, minha água rápido. Ra, ra, ra. Eu posso falar assim porque ela é minha secretária particular, minha filha. Obrigada, Carla.

Amor de mãe é tão puro, claro como a luz do dia. Puro como o amor de Deus, filho da virgem Maria.

Não tenho idéia de como se canta isso. Alguém sabe? Ninguém. Também não vem ao caso. Em frente. 
Visitei vó Ana num dia em que chovia torrencialmente. Desde a saída, em Santo Amaro, o ônibus já ia lotado. Ao meu lado, uma mulher chupava mangas. Primeiro a melancia, agora as mangas. Tem feira dentro desta linha? As pessoas se penduravam até mesmo na porta da frente. Com a chuva, o trânsito tornava-se lento. Era hora do rush. Os trabalhadores largavam as muitas indústrias da região. Boa parte do povo de Palhereiros, Parelheiros, Embura e Marsilac trabalha ali. Os pontos estão repletos de gente. As pessoas esticam o braço, fazem sinal, mas o ônibus de tão cheio nem pára. Atravessou mais de dez bairros sem pegar uma única pessoa. A avenida Senador Teotônio Vilela, que leva a Parelheiros, é subida e descida o tempo todo. O ônibus acelera fundo nas descidas para subir no embalo. Iraaaa. Izaura coloca a mão na região do abdômen para segura o frio na barriga. Usa até o acostamento para fazer as curvas. Quase atropela quem ali caminha.

Fim de linha. Marsilac parecia uma vila fantasma. Portas e janelas trancadas, rara alma pela rua. Apenas o canto de uma araponga corta o silêncio. A casa de vó Ana fica no alto de uma subidinha de terra. Tudo fechado e, aparentemente, não há ninguém ali. Chego mais perto, dois passos à frente em direção a nós, pé por pé, e então ouço o som de um rádio. Bato à porta, o punho se dobra duas vezes num gesto sugestivo, ouço um resmungo, pergunto por dona Ana e, pouco depois, a porta se abre e ela está diante de mim.

Dona Ana Rosa, 78 anos de vida, mora em Marsilac desde 1936, sempre na mesma casa de taipa que não deve ter mais de dez metros quadrados, porém com sala, quarto, cozinha e banheiro. Vó Ana pede que eu entre e me oferece uma cadeira. Ela senta-se em seu sofá.

- Estava chovendo e a luz elétrica acabou. Eu estava deitada aqui.

Essa daqui eu nem preciso caracterizar a voz, né. Velha por velha, pode ser a minha mesmo. Re, re, re.

- Será que a luz vai demorar?

- Sempre que chove a luz acaba e, às vezes só volta de madrugada. 
Fico mais perto da porta, aproveitando a claridade de fora para escrever. No rádio de pilhas tem início a Voz do Brasil.

- Por que vó, Izaura aumenta o volume da voz, Ana?

- Eu era parteira daqui. Agora não sou mais, por causa da idade. Mas quase todo mundo de Marsilac nasceu nas minhas mãos. Tá cheio de homem, até barbudo já, que me chama de mãe e de vó. Não só aqui, também em Parelheiros e Embura.

Vó Ana fala devagar e baixinho. Vige, eu precisaria ter mudado sim. Certas palavras ficam difíceis de compreender. Às vezes, entre uma frase e outra, dá uma risada para a qual parece que ela não tem força. Filha de pais mineiros, Ana Rosa nasceu em Bragança Paulista, de onde veio já casada. Ela abaixa o volume da voz que se torna meio rouca e compassada, Falavam que aqui dava dinheiro com a mão, né? Em Marsilac, opa, não é a vovozinha é o narrador, e corrige o timbre, em Marsilac ela teve dez filhos, quase todos morreram com um ou dois anos de idade. Apenas dois sobreviveram à infância. O filho que morreu em 1972, e a filha que casou e mora perto de Aparecida do Norte, com seus oito netos e 16 bisnetos. Vó Ana vive sozinha. O marido morreu em 1963.

Izaura representa a Vó Ana. Dito, meu filho, estava na vila quando meu marido chegou. Meu marido trabalhava na terra. Ele tomou banho, jantou e já ia deitar para dormir. Dito chegou em casa, mas logo saiu de novo. Havia um barulho lá fora, podia ser algum animal selvagem atacando o galinheiro.

- Fique aqui, mãe. Eu vou ver o que é.

Dona Ana ficou à porta. O filho pegou a espingarda e foi investigar. Descobriu que havia uma raposa selvagem rondando a casa. Fez pontaria, e descobriu que a arma estava sem balas.

- Mãe, fica aqui vigiando ela - correu, então, de volta à casa para recarregar. O pai, já deitado, ainda comentou:

- Nunca vi um caçador que vê o bicho primeiro e vai carregar a arma depois. 
Dito se sentiu mexido nos seus brios de caçador. Saiu de novo e agora sim, abateu o animal com um tiro certeiro. Tratou logo de apanhar a caça para mostrá-lo ao pai.

- $\quad$ Oia aqui, pai. Que beleza. PAI?

Pai. O grito de Izaura ecoa e nos assusta. Uma pausa. Seu semblante cai. Sua voz se torna fraca e tremida. Não sei até hoje do que ele morreu, mas sei que ele morreu com um sorriso nos lábios. Meu marido ficou morto aqui em casa por dois dias, que não tinha ninguém para levar ele até o cemitério em Parelheiros. Então tivemos que chamar um guincho. Ele não queria vir. Dizia que morava em São Paulo. Eu também, respondi pra ele. Sorrimos. Então ele veio.

Dona Ana Rosa quase nunca sai de Marsilac. Apenas para receber a pensão do INPS, na Cidade Dutra, quatro mil, meio salário mínimo. Dá pra viver?

- Dá, né. Agora o governo prometeu um abono, uma vizinha aqui recebeu quinze mil, mas acho que não vale para os pensionistas. Um saco de arroz tá setecentos, como é que eu vou fazer?

- A senhora nunca vai à cidade?

- Não, eu não preciso. Só quando tenho que receber. Esse ônibus demora tanto. Não posso andar muito que a minha pressão sobe logo. Ah, eu gosto de ficar aqui, é bom para a saúde, não tem poluição.

Vó Ana tem saudade dos tempos antigos de Marsilac.

- Naquela época é que era bom! Tinha mais recursos. Hoje, parece que a vila tá diminuindo.

Ela me conta que antes havia loja, farmácia, padaria e açougue. Pouco a pouco tudo foi acabando. Agora, até a igreja está ameaçada: o padre não vem mais. Vó Ana não esconde sua preocupação:

- Já estamos há um mês sem ninguém. Como a gente vai fazer sem missa?

É o ponto para os crentes da Assembléia de Deus, que fica num galpão de madeira azul logo na entrada de Marsilac. 
- Eles não gostam muito de mim porque eu costumo benzer as crianças. Mas eu digo: não é eu não, é Deus quem cura.

- Vem muitas crianças aqui?

- Vem de tudo quanto é lugar, até de Parelheiros, que tem médico. Só hoje vieram umas três ou quatro.

Ela me explica que cura criança de susto porque pode dar febre e quebranto e, nos adultos, dor de coluna. Tudo isso que os médicos não conseguem curar, né, Izaura reproduz a fala na mesma voz caricata que ela criou para a protagonista vó Ana. Dona Ana rebate as críticas que recebe com apenas uma frase: Deus é um só.

Começa a escurecer e nada da luz elétrica chegar. Era o que faltava para completar o quadro. Um lugar tão afastado e dali a pouco mergulhado na mais completa escuridão. A senhora não tem medo, morando aqui sozinha? Não, não tenho, as pessoas aqui me respeitam e não mexem comigo. A encenação do timbre de voz da vó Ana força a garganta e faz Izaura engasgar. Ela se abana um pouco com as folhas do texto, toma mais um bom tanto de água. A pele que havia se tornado um pouco avermelhada volta ao normal. Recuperada, prossegue.

- Já sim. Tem uns quatro anos. Xi, pulei um parágrafo, cadê, onde estávamos, ah sim, não mexem comigo. O certo é: antigamente.

- Antigamente era bem mais tranquilo. Agora não é mais. Nessa estradinha, mais pra baixo, ficam sempre uns rapazes fumando maconha. Um pouco mais longe tem um clube. Uma vez eles seguiram um rapaz que trabalhava lá e tinha ido receber. Eles mataram o rapaz que trabalhava lá e tinha ido receber. Opa, de novo. Não, não, não. Pera lá. Cadê. Acho que estou cansada. Um dia eu já fui boa nisso. Ra, ra, ra. Eles ma, pula a linha, taram, está aqui. Eles mataram o rapaz e levaram todo o dinheiro. Antes não tinha nada desse negócio de assalto... Ela olha para mim. Alertada para o horário de funcionamento da biblioteca deste o início, aponto para meu relógio. Vamos acelerar um pouquinho galera, avisa Izaura. Peço licença para fazer uma pequena edição para adiantarmos a leitura, depois vocês peguem seus textos e leiam na íntegra. Combinado? Nesta parte aqui toda ele ainda bate um bom lero com a Ana, daí começa a escurecer, a luz não chega, ele se pelando 
de medo, da vila, do jagunço, das cobras, de tudo, quer sair logo de Marsilac. Aqui, vamos ver. Podemos pular para a página seguinte. Ele está no ponto de ônibus e a luz elétrica chega. Recomeçamos aqui, depois que o autor coloca mais uma estrofe de música. E a letra escolhida é? Essa, todo mundo conhece. Quem sabe canta comigo. Toda a vez que eu viajava, vamos lá? Toda a vez que eu viajava pela estrada de Ouro Fino. Izaura se cala e continua com os gestos das mãos, nos instigando. Duas vozes, bem baixinho, se aventuram, De longe eu avistava, uma terceira voz se sobressai, a figura de um menino. Todos param. Até mesmo Izaura. O texto também parava ali. Mas a pessoa que entrara no final do refrão vai em frente, Que corria abrir a porteira depois vinha me pedindo, toque o berrante, seu moço, que é pra eu ficar ouvindo. Esse sabe, elogia Izaura. Incentivado, continua, Quando a boiada passava e a poeira ia baixando, ele, que está em uma das primeiras fileiras de cadeiras, se levanta e ensaia uns passinhos com Izaura, eu jogava uma moeda e ele saía pulando. Todos riem. Nós estamos avergonhados com a empolgação de nosso colega. O corajoso cantor não se intimida, Obrigado, boiadeiro, que Deus vá Ihe acompanhando. Prá aquele sertão afora, meu berrante ia tocando. Ele gargalha muito. Nós não. Nos entreolhamos, bochechas rosadas, os músculos das faces se preparam para soltar uma boa gargalhada, mas prendemos, ficamos apenas com um riso preso. Seus colegas zombam dele. É isso aí Wilson. Seguuuuura peão. Izaura pede colaboração para prosseguir, antes que dê o horário. Nos recompomos, e ela acelera um pouco mais o ritmo de leitura.

Enquanto aguardo o ônibus, lembro do encontro com seu Flávio, dono de dois sítios no km 53 e que está em Marsilac há apenas três meses mas, dizia ele, conhece tudo ali pela raiz.

No Lanches Claúdio, Flávio tomava caninha uma atrás da outra. Sentados numa das mesinhas, dois irmão violeiros eram o centro das atenções. Entre uma canção e outra, um gole de cerveja e uma mordida no churrasquinho, enquanto a assistência fazia os seus pedidos: toca essa, toca aquela. Flávio se aproxima deles e pede também uma música, o violeiro diz, ok, e começa a tocar $O$ menino da porteira, Izaura cantarola o que está escrito entre aspas no texto, Toda vez que eu viajava, e, apesar do autor e da Izaurinha parar aí, Wilson continua a música, pela estrada de Ouro fino, lá de longe 
eu avistava a figura de um menino. Receosos de mais uma longa apresentação musical, olho para Izaura, ela não sabe o que fazer, mas não é preciso, ele se contém, e ela pode continuar a leitura. Flávio chega perto de mim e sorri. Diz que essa música lhe traz muitas recordações, por isso ele a pediu. Izaura descarta mais uma página e coloca sobre as outras ao seu lado. Ameaça ler, mas identifica que está fora de ordem. Pega novamente aquela que acabara, é a página duzentos e cinquenta e três. Em suas mãos, procura a duzentos e cinquenta e quatro. Acha e reorganiza-as.

- Devem ser boas recordações.

- Não, não são - ele levanta a camisa e me mostra a marca de dois tiros na barriga - Eu estava cantando esta música na hora em que fui baleado. Eu também era violeiro lá na minha cidade, em Marília. Eu tava tocando num baile quando começou uma briga no salão. Nem vi de onde vieram as balas. Tinha um irmão que tava lá, junto comigo. Não vi mais ele desde aquele dia, fazem vinte anos já.

- As frases de Flávio são cortadas por vários sorrisos enigmáticos que me intrigam aos poucos.

- O senhor ainda toca?

- Não, nunca mais toquei depois do que aconteceu. Eu tenho violão, tenho sanfona, mas eu não mexo não - vira-se para o balcão - Ó neguinho, quanto é que eu devo?

Flávio paga a conta e continua a conversar comigo.

- Você não é daqui, né?

- Não, não sou.

- Sabe que é perigoso ficar aqui, né?

- Perigoso? Izaura faz cara de, não sei bem se de susto ou se é medo.

- É... Ela prolonga o "é” enquanto nos lança um olhar ameaçador. Aqui é problema.

- Que tipo de problema? Agora sim, a expressão dela é nitidamente com pavor.

- Dê uma olhada, observa bem esses sujeitos. Ó, tá vendo aquele grandão de boné perto da parede? Ele adora encostar o cano na cabeça dos outros. O negócio é eu ficar na minha. Eu tento me dar bem com todos, senão...Seu olhar é evasivo, não 
nos encara, seu dedo indicador em riste, balança-o como um sino em sinal de alerta. $\mathrm{O}$ complemento da frase é óbvio.

- Ninguém faz nada?

- Fazer o quê? Não tem polícia, já viu, né? Esse bar aqui é um dos mais perigosos. Tem realmente uns sujeitinhos que eu vou te contar... Ó, dá uma olhada aí atrás. Ela aponta para o fundo do salão. Coitadinha! Tão novinha e já nessa vida!

Eu me viro e vejo dois marmanjões, um altão de chapéu e shorts, o outro de shorts e camisa desabotoada mostrando uma barriga que eu nunca vi tão gorda. Eles se dedicam a embebedar duas mulheres, uma já meio coroa e a outra, a novinha. Vinha o altão e beijava a garota, depois vinha o outro e beijava também, aí eles iam beijar a coroa... E tome cerveja!

- É uma festa - comentei.

- Tem mesmo que tomar cuidado. O pessoal daqui arranja encrenca por qualquer coisinha. Olha lá atrás. Já vai dar bode.

Pela porta do outro lado saía um freguês. Rosto muito vermelho, visivelmente castigado pela cachaça. O rapaz, empregado do bar, o chama:

- Peraí, o senhor ainda tá devendo uma pinga.

O homem se virou com bronquidão e ódio, voltou ao bar e se projetou sobre o balcão. Izaura põe as poucas folhas que restam do texto sobre o tablado, a parte de cima do palco que ela usa de mesa e encosto, pois a altura desde com o chão do salão é exatamente o comprimento de suas pernas, olha e se prepara para uma grande encenação.

- Tô devendo o quê, seu filho da puta?

O sorriso coletivo é natural.

O rapaz se encolheu do lado de dentro. Aí chegou o pessoal do "calma, deixa disso" e seguraram o elemento, levaram-no para fora.

- Viu só? Quase... Bem, vou para o meu sítio, agora. O ex-violeiro se despediu. Descubro mais tarde que entre o sítio e a despedida há pelo menos quatro parágrafos. Se por engano ou de propósito, o fato é que o encaixe ficou perfeito. 
Foi para o sítio. Eu fui para o ponto de ônibus. Lá estava um japonês um tanto bêbado. Chega um rapaz, também visitante, e lhe pergunto (vejo no original do texto escrito pergunta; a correção foi oportuna):

- Por favor, onde é que tem um orelhão?

- Orelhão? Aqui não tem orelhão. Só em Embura.

Olho, então, em frente ao empório. Ali estão duas barras de ferro. Uma, onde ficava o orelhão. Outra, onde era a caixa do correio. Arrancaram tudo. Olho surpreso para o japonês:

- Não tem orelhão em nenhum outro lugar?

O japonês balançou a cabeça e limitou-se a dizer:

- Aqui é foda!

Fico na minha. Ao meu lado, outros passageiros esperam pela condução. O sol vai sumindo e os pernilongos saem à caça. Ficam sobrevoando a cabeça das pessoas, principalmente a minha. Parecem que eles sabem que eu não sou dali. Foi o que ouvi de um grupo que sentava no mesmo banco:

- Pô, mas quanto mosquito! Tá faltando agora é uma máquina pra bater.

- Tem mais mosquito em cima do visitante aqui.

Em suas mãos, apenas a última página.

- É... Carne nova.

Aqui é foda.

Está acabando, brinca. A última do repertório do nosso autor aqui é: No rancho fundo, bem pra lá do fim do mundo. Ela apenas lê sem entoar o verso e já engata a finalização da narrativa. Já é noite. Volta e meia caem uns chuviscos mais fortes. Finalmente, chega o único elo dali com o resto do mundo, um CMTC que, como uma máquina do tempo, vai me levar de volta à contemporaneidade.

Dez minutos mais. Pausa para um aperitivo no bar. Um cigarro. E então cobrador e motorista se despedem de quem fica. Partimos, enfim.

Os estragos da chuva ainda estão presentes. A maior parte do caminho continua sem luz. Estreito, sinuoso, esburacado, encharcado, esquecido, desprovido 
da menor sinalização e agora totalmente negro. As curvas da estrada das Setes Curvas tornam-se ainda mais mortais.

O ônibus agora é um vagalume na Serra do Mar. Segue quase vazio. O cobrador sai do seu posto e vai conversar com o motorista, que às vezes ainda se dá ao luxo de soltar o volante e olhar para o lado para falar. Será que nosso amigo está cagando de medo, turma. Re, re, re.

- É a primeira vez que faço essa linha - diz o cobrador - Isso aqui é o fim do mundo.

- Tô nessa linha há três anos. Já morreu motorista aqui nessas curvas. Um ou outro sai no jornal. A Prefeitura diz que são só uns cinco. Mas na verdade já morreu mais de trinta... Há pouco tempo um colega meu morreu aqui. Quando ele viu que ia bater, abriu a porta e saltou para fora. Deu de cara com um poste. A cabeça dele ficou esmigalhada. O ônibus bateu, virou e ficou com as rodas para cima. Tinha um monte de passageiro morto...

Alguém comenta: que macabro!

O vagalume se perde entre as luzes de Interlagos, dos semáforos, dos shoppings centers e seus letreiros luminosos, dos automóveis, das torres de TV, símbolos de uma apregoada modernidade chamada São Paulo.

No mesmo espaço, o tempo se confunde. Lado a lado, os galpões de Marsilac e os arranha-céus da Paulista. A estrada das Sete Curvas e as avenidas expressas. São Paulo que cresce absurdamente. Marsilac, que encolhe a todo ano, cai no esquecimento. Marsilac, que não tem farmácia, nem padaria, nem médico, nem polícia, nem orelhão. Marsilac, que, quando descerem as próximas brumas da Serra do Mar, pode desaparecer para sempre.

Ela completa a pilha de folhas sobre o palco, missão cumprida. Aplausos. Ela agradece com um olhar doce e encurvando para frente. Mais aplausos. Os meninos se levantam. Estão afoitos para saber um pouco mais sobre Marsilac, da coleção São Paulo de Perfil, e, claro, principalmente, tudo de Izaura. 
Duas semanas após a leitura de Izaura na biblioteca do Ipiranga, recebo a visita de um dos participantes do sarau, que se apresenta como Rodrigo DiCaprio. Traz, em mãos, a pedido de Wilson - um dos leitores que acompanhou o sarau do Ipiranga -, uma carta e textos de autoria dele, o Wilson, para eu avaliar. São manuscritos em papel sulfite, com letra cuidadosamente decorativa. Leio o primeiro e, emocionada, disparo dizendo que não sou professora, não posso avaliar, e, se fosse, acho que não é passível de correção. Diga a ele que, como leitora, fui tocada, comovida. Rodrigo então me explica que Wilson, há muitos anos, faz tratamento psiquiátrico. A carta é um agradecimento, porque no dia do sarau, ele teve uma inspiração pra escrever, e isso fez muito bem, a ponto de não lhe ocorrer as habituais crises noturnas. Fico sem palavras. Procuro ler mais uma das folhas. Rodrigo conta que Wilson deseja que eu fique com tudo aquilo. São como presentes. Como relíquias, conforme fala Izaurinha. 


\section{Capítulo 2}

\section{Quem é Isaura?}

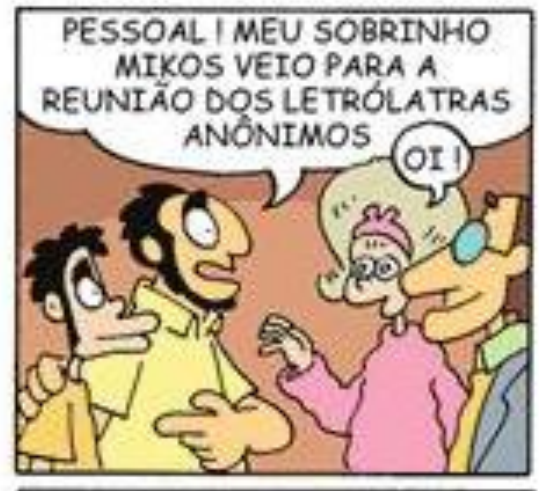

PUXAINESSA IDADE. ELE JA E DEPENDENTE

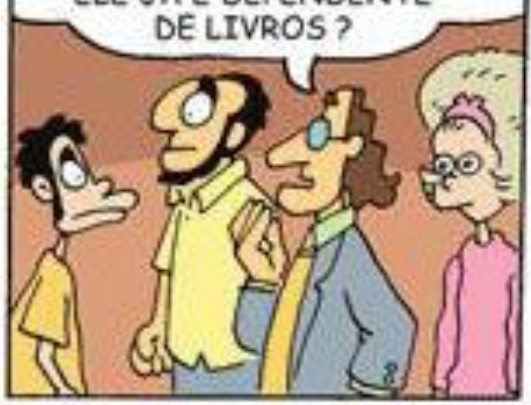

SÓ HARRY POTTER ! E VOCE NAOO IMAGINA O ESTRAGO QUE FAZ

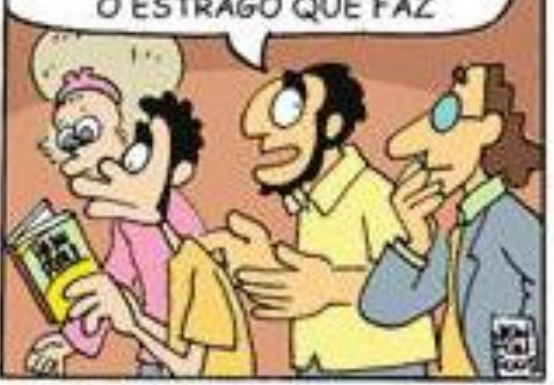

ESCOLA DE COMUNICAÇÕES E ARTES Doutorado em Ciências da Comunicação Teoria e Pesquisa em Comunicação 


\title{
Capítulo 2
}

\section{Leitura}

\section{Quem é Isaura?}

\author{
Sou um contador de história \\ Por este Brasil afora \\ Levo alegria e tiro sorrisos \\ Induzo a muitas imaginações \\ Provoco perguntas e exclamações \\ Sou um contador de história \\ Procuro reviver a memória \\ Trazer contos e causos \\ Num linguajar que se faz entender \\ E entreter, tirar gargalhadas \\ Deixando mensagens marcadas \\ Sou um contador de história \\ Mexo com o Ser criança \\ Alimento a esperança \\ De cidade em cidade \\ Independente da idade \\ Usando da diversidade \\ Vou desnudando a fantasia \\ Em cada rosto vendo a alegria \\ Nos personagem que se cria \\ Sou um contador de história \\ De lugar em lugar \\ Vou deixando minha marca \\ Presente viva na lembrança \\ Registrando cada infância \\ Construindo bordões \\ E personagens que permanecerão \\ Pelas gerações \\ Sou um contador de história \\ Não perco a oportunidade \\ De trazer à tona a realidade \\ Satirizando os contextos sociais \\ No dialeto, no jeito de expressar \\ Uma forma de criticar \\ Levando o público a pensar
}

Contador de História de Ataíde Lemos, um contador de história

Quando conheci o Fórum Permanente Interdisciplinar e os trabalhos do São

Paulo de Perfil, ela já estava lá. Há três anos, desde 1999, um ano após a disciplina

"Narrativas da Contemporaneidade" ser oferecida ao Programa Universidade Aberta à 
Terceira Idade. Só não cursou já no primeiro ano, em 1998, devido à simultaneidade com a aula que Izaura Marques Piffer já cursava, "A aventura de fazer jornal", do professor Manuel Chaparro. Inicia sua participação no São Paulo de Perfil na $23^{\mathrm{a}}$ publicação da série ${ }^{2}$, Ó Freguesias, quantas histórias, livro que escolheu o bairro como símbolo da história de São Paulo nos últimos quinhentos anos.

Em 2001, quando nos conhecemos, ela trabalhava na narrativa que comporia $24^{\circ}$ volume, Sagas do Espigão, 90 anos de Medicina e Vida, a respeito do Complexo das Clínicas. Aos poucos descobri sua habilidade de narrar que ela própria sugere ter vindo de sua trajetória: a vida nos transforma em contadores de histórias, ela me segredou uma vez. O detalhe no percurso de Izaura é sua profissão: radio-atriz. Em abril de 1941, sob chuva forte, ela entrou no prédio da Rádio Piratininga, foi atendida pelo diretor do rádio-teatro, Otávio Augusto Vamprê. Passou no teste de dicção e estreou no Grande Teatro Piratininga com um pequena fala. Responderia sim, senhor ao pedido de um personagem. Era pra ser assim, mas foi: sim, senhor, pois não, um instante, já vou atender. Deve ser o doutor Jaime. Ele disse que viria falar com o senhor. Daí iniciou-se uma carreira de 44 anos em rádio, com direito ao troféu Viola de Ouro como melhor atriz de programa sertanejo na TV Globo. Era ela quem dublava o Kuru do Nacional Kid, primeiro filme japonês com efeitos especiais que veio para o Brasil. Minha mãe ficou fascinada quando soube que eu conhecera a voz do garoto de seis anos da série.

\footnotetext{
2 Volumes já publicados: 1. Virado à Paulista (1987); 2. Vozes da Crise (1987); 3. Nos Passos da Rebeldia (1987); 4. Forró na Garoa (1989); 5. Hermanos Aqui (1989); 6. A Casa Imaginária (1989); 7. Paulicéia Prometida (1990); 8. À Margem do Ipiranga (1990); 9. A Escola no Outono (1991); 10. O Primeiro habitante (1991); 11. Farra Alforria (1992); 12. Tchau Itália, Ciao Brasil (1993); 13. Guia das Almas (1993); 14. Nau dos Desejos (1994); 15. Vamos ao Centro (1994); 16. Axé (1996); 17. Tietê, Mãe das Águas (1995); 18. Viagem ao Sol Poente (2001); 19. Bem Viver, Mal Viver (1996); 20. Mundão Veio sem Porteira (1997); 21. Chá de Bambu (1998); 22. Cotidianos do Metrô (1999); 23. Ó Freguesia, Quantas Histórias (2000); 24. Sagas do Espigão, 90 anos de Medicina e Vida (2002); 25. Caminho do café. Paranapiacaba: museu esquecido (2004); 26. USP Leste e seus vizinhos (2005).
} 
Não acompanhei a carreira de Izaura, não vivi rádio-novela, rádio-teatro e nem Nacional Kid. Em dez minutos de conversa você entende o que é desenvoltura com a fala, envolvimento com a platéia, sedução do espectador. Izaura é simpática, bem humorada e dá muitas risadas. Quando me propus a oficializar os saraus, em ambiente de pessoas desconhecidas, pedi socorro para a experiência. É ela que me ensina esta rádio-leitura que faz, sem muitas peripécias, as palavras ganharem cenário, luz, ação e emoção.

É a Izaura Marques quem nos narra quem é Izaurinha. A vida nos transforma em contadores de histórias, é sua síntese retrospectiva. E segue.

É fácil relatarmos a trajetória do outro, mas quando se trata da nossa, ficamos engasgados. Não sabemos ao certo como iniciar, o andamento que deve ter, nem como terminar. O tempo passa com a rapidez de um supersônico e trazer à tona os fatos pela ordem acontecida, desmembrar, achar o fio da meada no labirinto da memória é um trabalho que exige sabedoria.

Sua vida profissional começa em abril de 1941. Uma chuva forte a faz entrar em um prédio da Rua Conselheiro Crispiniano quase esquina da Avenida São João. Por curiosidade lê sua tabuleta e em um dos andares estava mencionado Rádio Piratininga. Não pensou duas vezes. Acostumada desde seus dez anos a participar do programa infanto-juvenil da Rádio Educadora de Campinas e depois em São Paulo na Rádio Bandeirantes, que ficava na Rua São Bento, nos programas Mulher de Sagramor Escuveiro, e do Ave Maria, do Jota Junior, tomou o elevador e desceu no andar indicado. Com a facilidade que hoje não existe mais, foi atendida pelo diretor do rádioteatro, Otávio Augusto Vamprê. Fez na mesma hora um teste de voz, leitura de texto e acertou que na quarta-feira estrearia no Grande Teatro Piratininga. 
Dia 16, às 19 horas, lá estava pronta para a estréia, mas uma surpresa a esperava. Vamprê havia se transferido para a Rádio São Paulo e em seu lugar estava Raimundo Lopes, que a recebeu com toda firmeza dos antigos diretores.

- Participar do Grande Teatro, hoje. Mas de jeito nenhum, não conheço suas possibilidades.

- Não importa.

- Como não. Além disso, não há na peça papel adequado para principiante.

- Crie um. Avisei meus pais da minha estréia e não devo, não posso e não vou decepcioná-los.

Raimundo respirou fundo e a levou para a sala de ensaio onde já estavam os atores, Lucilia Freire, Antonieta Soneti, Climaco Cezar e Carlos Maia que, além de ator, era médico. Papéis distribuídos, Raimundo inicia o ensaio dizendo; vamos ver se encontramos uma cena para a encaixarmos. E a encontrou, quando o contra-regra, tocava a campainha de porta: É aqui. Climaco, marque... você vai dizer, Maria, atenda a porta, disse Raimundo, e dirigindo-se a ela, e você diz... sim senhor. Está bem.

Aí tinha sua esperada estréia respondendo, sim senhor. Mas na hora esticou a fala, sim senhor, pois não, um instante, já vou atender. Deve ser o doutor Jaime. Ele disse que viria falar com o senhor. O programa não era gravado como atualmente, e a esticadinha já tinha ido ao ar, dando início a uma carreira que durou 44 anos de rádio intercalado com shows, teatro, televisão, dublagem, gravações em disco de histórias infantis, publicidade. Redatora de quadros de humorismo como Cartomante Fiu-Fiu e dramáticos Uma Voz ao Telefone, Isto Aconteceu Comigo. Programa feminino, adaptações de filmes e contos, para as rádios São Paulo, Bandeirantes, Excelsior e Nacional e para TV o Teatro de Bolso (Globo). Recebeu o troféu "Viola de Ouro" como melhor atriz de programa sertanejo na TV Globo. Aposentada, ainda continuou por mais 
cinco anos na ativa fazendo cinema de animação, audiovisuais e como professora em cursos de teatro e oratória. Dirigiu grupos amadores. Contou histórias em escolas.

Para o nosso consumo, era dá uma canja da origem da palavra radialista. Ela que explica: quem trabalhava em uma emissora de rádio o fazia quase que somente para satisfazer o seu prazer, seu deslumbramento. Por isso, era considerado idealista. Então, Nicolau Tuma teve a idéia de juntar as palavras rádio e idealista e deu radialista. Hoje o ideal esta sendo trocado por faturar.

Nunca usou nome artístico. Sempre foi o de batismo, Izaura Marques.

Com meio século de carreira atuou em várias rádios e tvs. Rádios, acho que todas, de São Paulo. Comecei, como já citado, na Piratininga que foi à falência. Fui para a Difusora a convite de Raimundo Lopes. Houve uma junção da Tupi com a Difusora e passei a pertencer ao elenco também da Tupi sob a direção de Otávio Gabus Mendes. Nesse tempo participava do programa de auditório Revista Escândalo, da rádio Cosmos, hoje América. Aqui cabe uma curiosidade. Você sabia que foi o antigo dono da Cosmos que implantou um sistema de pesquisa que resultou no tão conhecido e temido IBOPE? Em 1943, Oduvaldo Viana veio do Rio para dirigir a rádio Panamericana que inaugurava e lá fui eu. Quando a Pan foi vendida para Paulo Machado de Carvalho e transformada em Jovem-Pan, o cast do teatro foi transferido para a São Paulo que já era especializada em rádio-teatro. De vez em quando participava de programas da Record, emprestada pela São Paulo, até que me transferi para a Cruzeiro do Sul, que tinha os estúdios na Praça do Patriarca. A direção era do Cassiano Gabus Mendes e de Ivany Ribeiro que, um ano depois, foi contratada pela Bandeirantes (rua Libero Badaró) e me levou junto. Era diretor geral o locutor esportivo Rebelo Júnior, criador desse gooool prolongado que todos os locutores usam na transmissão de uma partida futebolística e que deu a ele o título de $O$ homem do goool inconfundível. A Bandeirantes mudou para a Rua Paula Souza, e eu para a Rádio Excelsior, com Mário Donato que, às vezes, 
emprestava atores para a Educadora. Com o surgimento da Nacional, todo o elenco atuava na Excelsior e na Nacional, onde me fixei por 34 anos. Gravei programa educativo para a Rádio Cultura. Em TV participei desde 1954 até me aposentar, na Organização Vitor Costa, Globo, TV Cultura, SBT e Excelsior.

O rádio-teatro foi famoso nos tempos da Izaura, lá pelas décadas de 1950 e 1960. Para que uma emissora apresentasse um bom rádio-teatro, segundo Izaura, era necessário uma série de "bom”. Bom elenco versátil, bom texto, bom diretor, bom contra-regra, bom sonoplasta. Tinha de ser um grupo jóia. Embora pudesse haver num elenco algum "canastrão", no todo tinha que ser de primeira. Mas um bom diretor podia fazer de um canastrão, um ator. O contra-regra, ou seja, o responsável por todos os efeitos sonoros, se errasse estragaria toda uma cena. As músicas para temas ou mesmo em BG eram muito bem escolhidas pelo sonoplasta e deviam entrar na hora certa. $\mathrm{O}$ texto bom para despertar o interesse do ouvinte. Enfim se tudo não fosse muito bom, perderia audiência. Outra coisa interessante é que as novelas de rádio faziam a cabeça do ouvinte trabalhar, porque era ele quem idealizava os cenários, já as novelas televisivas mostram tudo pronto e as cabeças não trabalham.

Em 2005 Izaura voltou a gravar novelas para a rádio Record. Percebeu muita diferença na forma de trabalho. Na verdade, a Rádio Nacional ou Globo, onde atuei por mais de trinta anos, já gravava a programação, por isso gravar não representava novidade. O que estranhei foi que não há mais ensaio. Grava-se direto, às vezes diálogos ou mesmo só as falas de cada personagem. Depois é que fazem uma montagem. Achei falta nas rubricas engraçadas que ilustravam os antigos textos (ruído de assoar o nariz), em Éramos Seis, levada pela Record ou (chocar de corpos) que queria dizer abraço. Enfim, essa série foi um jogo de cintura para mim porque só sabia que era uma cigana. É muito bom gravar, assim não vai ao ar nenhuma falha. Mas que os nossos erros eram divertidos, eram. Na Pan, Alair Nazaré tinha que dizer: sempre que 
ela volta da missa, ela toca essa música e ela trocou a ordem, sempre que ela volta da música, ela toca essa missa. Um locutor também da Pan cometeu um erro ao ler uma propaganda, hoje mais conhecido como comercial, e disse "Aveia qualquer", mas com muita presença de espírito corrigiu em cima: aveia "qualquer" não, exija aveia “Quaker”. Numa novela religiosa, se não me engano era a vida de Santa Edwiges, dialogando com Walter Forster, eu dizia ponha sua "mão" em meu ombro e muito compenetrada disse, ponha sua "mãe" em meu ombro. Agora vexame mesmo foi eu quem passei. Lembro de três. Fui escalada para substituir uma colega que ficara afônica. Era um quadro de auditório, Primo João, e o início era cantado. Fiquei gelada porque eu não canto nem debaixo do chuveiro. Ensaiei a cantoria com acompanhamento de piano, mas na apresentação o que entrou foi a orquestra do Silvio Mazuca. Fiquei totalmente perdida, apesar de um dos músicos levantar e tocar a melodia com o pistom, eu não me encontrei. Isso foi na rádio Bandeirantes. Outra vez foi fazendo um show beneficente, num clube na avenida Ipiranga, num esquete com Osmano Cardoso. Entrei eufórica no palco e eufórica caí com as pernas para o alto e de frente para platéia que riu a bandeiras despregadas. Mas o que mais me deixou nervosa, confusa, aconteceu na penitenciária, no antigo Carandiru. Novamente dialogando com Walter Forster, garbosamente usava um vestido "tomara que caia" e ele quase caiu mesmo. Um contra-regra da Globo costumava dizer quando errava: desculpe a vergonha que passei, e foi o que eu disse no show para os detentos. Um errinho era uma tragédia tanto na rádio, como no início da TV que a programação era ao vivo, nos obrigando a ter a memória na palma das mãos. Depois chegou o vídeo, mas ele não voltava, tínhamos que gravar direto e ficar no estúdio esperando para saber se estava tudo certo ou se tínhamos que regravar. Era um sufoco.

Sua voz não ficou apenas no rádio, Izaurinha também dublou seriados. Dublei longa metragem também e muito. O mais marcante foi o Nacional Kid. Primeiro filme 
japonês com efeitos especiais que veio para o Brasil. Dublava um garoto de seus 6 anos, Kuru. Ainda hoje muita gente lembra do Nacional Kid. Era a alegria da criançada nos anos 60. Sabe, a dublagem também acompanhou o tempo. Em 50 e 60 o filme era dividido em anéis, e todos os dubladores que participavam daquele trecho dublavam juntos. Tínhamos que falar dando sincronismo absoluto ao modo de falar do ator cinematográfico e quando um dublador errava, voltava todo anel por várias vezes (dez, trinta ou ainda mais). Difícil, não é? Mas hoje é bem mais fácil, se trabalha com fone de ouvido.

Izaurinha não é dos tempos dos cursos de especialização. Sei que hoje esses cursos se espalham, mas não. Tanto na rádio, na dublagem como na TV e também no teatro, aprendíamos com cada diretor. Tive excelentes diretores; Raimundo Lopes, Otávio Gabus Mendes, Farid Riscala, Talma de Oliveira, Júlio Atlas, Ivani Ribeiro, Túlio de Lemos, Renan Alves, Daniel Filho, Oduvaldo Viana, Luiz Pini, Eny Autran, Carlos Machado e outros que talvez agora tenha me fugido. Todos muito exigentes. Na rádio São Paulo havia um diretor que costuma dizer quando tínhamos poucas falas: tu tens poucas falas, mas elas devem ser ditas e muito bem ditas. Na Panamericana, hoje Jovem Pan, a programação de auditório era decorada, um verdadeiro teatro. Aprendi muito, e tanto fazia papéis dramáticos como caricatos. Na TV era comediante, e saiba que é muito mais fácil fazer o público chorar do que rir. Em várias situações cheguei a fazer dois papéis ao mesmo tempo, tendo que dialogar comigo mesma. Pó de Pirlim... Pim, Pim, de Monteiro Lobato, adaptado para disco, interpretei Pedrinho e Narizinho. Outra boa escola foi fazer quadros em vários programas, ao vivo e de improviso. Com Manoel de Nóbrega, em programa de auditório na rádio Nacional os quadros Adão $e$ Eva e o do ventríloquo que era o Nobrega, eu e o Canarinho, que ainda está na ativa, fazíamos os bonecos, era um quadro muito divertido. Outro programa de grande audiência foi A Praça da Alegria, atualmente apresentada por Carlos Alberto de 
Nóbrega, pelo SBT como A Praça é Nossa, e onde eu fazia a Lili, a menininha mais sabida, enquanto o Ronald Golias era o garoto mais atrasado da Escolinha de Grupo. O teatro, na Companhia de Hilda Asson sob a direção de Hélio Quaresma, foi uma boa escola. Mas o teatro infantil nos dá mais trabalho, a criança é mais exigente, mais crítica. Contudo, vou revelar a você, o que me deu mais lição de trabalho e de vida, foram os shows que fazíamos com a Caravana do Nóbrega, todo fim de semana em circos de periferia.

Meus colegas de trabalhos formam uma lista que pode ser interminável, porque todo radialista era meu colega. Alguns já nos deixaram saudosos, outros ainda estão em atividade. Na TV, Tarcísio Meira, Francisco Cuoco, Lucimara Parisi, Osvaldo Louzada, Nair Belo, Renato Consorte e muitos outros. Dubladores, Yveti Jaime, Borges de Barros, Helena Samara, Gilmara Sanches. Os de rádio, todos os radialistas das décadas de 40 a 80 (século passado). A rádio continua funcionando, mas para o rádio-teatro o mercado está fechado.

Não sobrava tempo para decorar texto. Tinha praticamente uma apresentação atrás da outra. Costumava fazer isso durante os ensaios ou mesmo enquanto ia uma cena que não participava, decorava a minha. Memória fotográfica. Mas sabe, muitas vezes acontecia de colocarmos nossa "colinha" nos cenários e depois do ensaio geral o diretor de estúdio trocar tudo e a nossa salvação ia pro brejo. Foi trabalhosa a programação de TV no início, os cenários eram precários, não se faziam externas e o guarda roupa vinha da casa teatral. O que salvava mesmo era o elenco excelente. Até os comerciais eram ao vivo.

Até agora a heroína, e sobre os não tão méritos assim? Vários... em 1943, na Pan, o locutor esportivo Nage criou um programa que ia ao ar das $12 \mathrm{~h}$ às $12 \mathrm{~h} 30$ chamado Nageada. Era um casal, ele e eu, que discutia futebol. Fui então insistentemente convidada pelo Nage a ser comentarista de campo e não quis. Achava 
que não entendia de futebol e seria um fracasso. Em 52, já na Excelsior quase fui para o cinema e desisti. Havia um teatro na TV que era feito por artistas de teatro vindos do Rio. Uma ocasião veio o Procópio Ferreira e uma atriz não pode vir e a Globo me pediu socorro. Lá fui eu. Não havia tempo para ensaiar quanto mais para decorar o texto, teria que improvisar. Então o Procópio explicou que era uma empregada jeitosa querendo conquistar o patrão, que era ele, que o papel atravessava a peça toda e lá fomos nós para o ar. Quando terminou, Procópio disse: o que fica fazendo em São Paulo, Izaura. Tem que ir para o Rio, menina. Agradeci, mas... Também em 65, quando a Globo passou a funcionar no Rio, muitos colegas se transferiram para lá e eu preferi continuar aqui. Agora "fora" mesmo eu dei, quando a Globo me propôs ser jornalista, hoje seria ótimo. Já disse a você que os comerciais iam ao ar ao vivo, não foi? Contrataram então algumas garotas para esse fim, mas o número de Garota Propaganda era pequeno e começaram a escalar as atrizes para completar o quadro. Eu não queria porque meus horários já eram terríveis e teria que ficar a tarde toda trancafiada na TV. Fui falar com Paulo de Gramond que era diretor artístico: Paulo eu sou atriz e não garota propaganda. E ele, muito diretor, respondeu: pois faça de conta que é um teatro onde interpreta esse papel. Saí da sala pensando; tenho que arranjar um jeito e arranjei. Havia uma propaganda de um bendito "pente". Pedi ao câmera que focalizasse nosso contra-regra que era totalmente calvo e fiz o comercial: façam como o Darci. Ele adora este pente, não usa outro, não é Darci? Fui chamada na direção - que isso não se repita. O próximo comercial era sobre um copo térmico para aquecer mamadeira e eu: querido papai, acabou seu desespero por ter que se levantar a noite para preparar a mamadeira do seu neném. Deixe-a pronta dentro deste recipiente térmico e, quando ele berrar, é fácil o papai fazê-lo calar. Novo chamado: como você fala com o pai, é com a mãe. O terceiro foi a conta exata para sair dos comerciais. Era sobre um prato elétrico para esquentar 
comida, pão etc. e eu bem sexy: minha senhora este prato é ótimo para esquentar o que a senhora "precisar esquentar". Fui censurada. Nunca mais fui escalada.

Por falar em censura... Num quadro de humorismo na Excelcior interpretando uma garçonete, dizia a dois fregueses que não queriam nada: mas nem uma cochinha... de galinha. Os três pontinhos fizeram o auditório rir e eu levar a maior broca. Quando as peças sofriam censura tinham que ser trocadas na última hora, dava um trabalho danado. Já na TV, essa você vai rir, quando uma atriz estava esperando nenê só fazia cenas em off ou de trás de janela, coisas assim, porque era proibido grávida na $\mathrm{TV}$, decerto porque "lembrava" sexo. Hoje...

Como era o assédio dos ouvintes? Recebíamos uma calorosa correspondência quase que de todo o Brasil. Éramos reconhecidos pelos fãs em qualquer lugar, porque tínhamos uma excelente programação de auditório com as orquestras, de Silvio Mazuca, Migliori, Gaó, Guerra Peixe, Osmar Milani, Marcelo Tupinambá e apresentação de grandes cantores, partindo de Dorival Caymmi, intercalados com quadros de rádioteatro. Era um público que aplaudia, não era comandado, regido, mas espontâneo. Também as reportagens em revistas especializadas, como a Revista do Rádio, e em jornais eram constantes e muito bem feitas. Havia também um álbum do Rádio, que tenho até hoje, e um outro que era de bala que vinha com fotos de todos os radialistas. Você comprava as balas e ia formando o álbum. E, quer saber, até hoje encontro antigos fãs que ficam felizes quando me vêem. Um exemplo. O nosso colega de jornalismo, no Reproposta (projeto da Universidade Aberta à Terceira Idade do Fórum Permanente Interdisciplinar), Modesto Laruccia, disse: tive paciência de esperar 52 anos para ter a honra de ser incluído no rol de suas amizades. Um antigo admirador da sempre jovem atriz. E ainda sou procurada para entrevista por rádios, jornais e revistas, o que é gratificante. 
Há fatos especiais na em sua trajetória. Não estou lembrada qual era o programa, mas lembro do corre-corre terrível com tiros e tudo... Era época da ditadura e tínhamos na Rádio Panamericana, um bom elenco perseguido: Oduvaldo Viana, Mário Lago, Dias Gomes, Agostinho Aguiar Leitão e outros que agora não recordo. Só sei que como num passe de mágica todos viraram super-homens e saíram voando por todos os lados.

Um dos aniversários do programa Manoel de Nóbrega foi transmitido diretamente do cine Piratininga, que ficava entre o Brás e o Belém, na avenida Rangel Pestana e era considerado o maior da América Latina, foi inesquecível. Além de estar totalmente lotado, os aplausos eram tão calorosos que dava a impressão de que ia haver uma implosão. Também em Brasília, apresentando o programa do Silvio Santos já no SBT, havia gente pendurada de todo jeito e olhe que o espaço era grande. Tivemos que sair como que foragidos e mesmo assim nossos carros foram bloqueados pelos fãs, foi uma loucura. As festas de aniversário da Nacional deixaram uma lembrança gostosa.

No carnaval de 1987, graças ao meu currículo, fui escolhida para jurada das escolas de samba de São Paulo no quesito samba no pé. A emoção provocada pelas baterias durou até saírem os resultados... ou até hoje.

Agora, um momento particularmente especial aconteceu quando atuava na Rádio São Paulo, lá na avenida Brigadeiro Luiz Antônio. Levávamos ao ar a novela Entre Dois Mundos, do novelista Agostinho Aguiar Leitão. Interpretava um garotinho que era décimo terceiro filho de um casal. Esse personagem vivia entre o mundo material e o espiritual, era muito bonito, de muita sensibilidade. Fui, então, procurada pelos pais de um menino que, em fase terminal, dizia que não queria morrer sem conhecer a artista que interpretava o Zabelê. Conheci, emocionada, esse menino de 12 anos. Poucos dias depois ele faleceu. Essas passagens não se esquecem.

Ah, outro fato que marcou foi em 1952 na Excelsior, quando o redator José Ferreira Carrato criou um programa chamado Meu Filho, Meu Orgulho. Era a 
radiofonização sobre um bom filho e a mãe recebia de presente um lindo broche de ouro. Tive a alegria de ser a heroína em um deles e minha mãe homenageada. Agora transferi o símbolo de meu filho, meu orgulho para minha filha Camila que me deu cinco netos.

Trabalho e mais trabalho. E sua vida particular? Conciliar foi um pouco difícil. Um pouco. Nem sempre tinha empregada, ou pelo menos confiável, e tinha que levar minhas filhas comigo para todo lado, mas sempre pude contar com colegas que se transformavam em pagens em meu socorro e meu marido me incentivava muito.

Tem uma coisa me confundindo. Às vezes você fala Nacional, outras vezes Globo... Não há nada confuso. A história foi assim. Em 1950 me transferi da rádio Bandeirantes para a Excelsior, dirigida por Mário Donato. Em 1952, Victor Costa, da rádio Nacional do Rio de Janeiro, propôs à Excelsior uma junção e fundou a Nacional de São Paulo. Passamos, então, a trabalhar para as duas emissoras. Os programas vinham do Rio. Um deles, de muito sucesso, o Balança Mas Não Cai. Um ano e meio ou dois, Vitor Costa comprou a TV Paulista que ficava bem ali na Rua da Consolação, esquina da avenida Paulista, e foi formada então a Organização Vitor Costa. Com o falecimento do Vitor, foi que passou a ser Globo. A TV Globo, creio que em 1965, passou em parte a funcionar no Rio.

Parei porque queria descansar um pouco, "saborear os netos", e, se um artista para uma temporada, voltar é complicado. Parei entre aspas, né. Continuo ativa. Se você for ao Arquivo do Estado sobre Histórias dos Bairros me achará lá. Foi uma entrevista sobre Santana, feita por historiadores. Um trabalho muito bonito. Outro que achei bastante interessante foi o livro editado pela Droga Raia, Páginas da Vida, com relatos de seus clientes. Lá eu narro um natal de minha infância. Frequento cursos abertos à terceira idade na Universidade de São Paulo. São atividades que envolvem jornalismo, leitura e interpretação de texto; participo da publicação de livros-reportagem e das aulas 
da disciplina Narrativas da Contemporaneidade. Isso aumenta meu saber, promovendo minha participação em vários projetos culturais.

Fiz na Oficina Cultural Oswaldo de Andrade, no projeto Perdigoto, com a coordenação de Antônio Prata e Chico Matoso, a publicação de cinco contos na revista Sentidos. Na faculdade Santana, vídeo palestra sobre rádio. Redijo crônicas ou contos para o "espaço aberto" do jornal Reproposta, que foi criado pelo professor Dr. Manoel Carlos Chaparro. Escrevi narrativas para quatro edições do Projeto São Paulo de Perfil, idealizado e coordenado pela professora Dra. Cremilda Medina. Atuo em saraus literários realizado em bibliotecas e escolas públicas.

A profissão de Izaura e sua filosofia de vida se confundem. Para ela, todo problema tem solução. E, se há solução, então deixou de ser problema. Um otimismo que pensa ter sido herdado de sua mãe, mas o jeito brincalhão está mais para o código genético do pai. Não, não é alienação. É uma questão prática: você reconhece que a vida não é só maravilha e não se desespera porque desespero não leva a lugar nenhum. Izaura também garante que otimismo atrai otimistas. Drama fica só na ficção, a vida não pode se em um drama, e para que isto não aconteça, ela garante que rir é realmente o melhor remédio. E neste ponto é que fica mais evidente sua profissão e o seu jeito de ser. Izaura tem o dom e é profissional do fazer rir. De todas as atividades que relatamos acima passaram-se 44 anos, primeiro no rádio e depois na televisão, em que ela foi comediante. Tristeza e mau humor só fazem envelhecer a gente. A boca e as sobrancelhas caem, a testa enruga. Posso afirmar que essas aberturas enriquecem a minha vida, aumentado o tamanho de minha relíquia. Porque... nossa memória é uma relíquia que guardamos carinhosamente. 


\section{Capítulo 3}

\section{Isaurau: 0 conto da sereia Isaura}
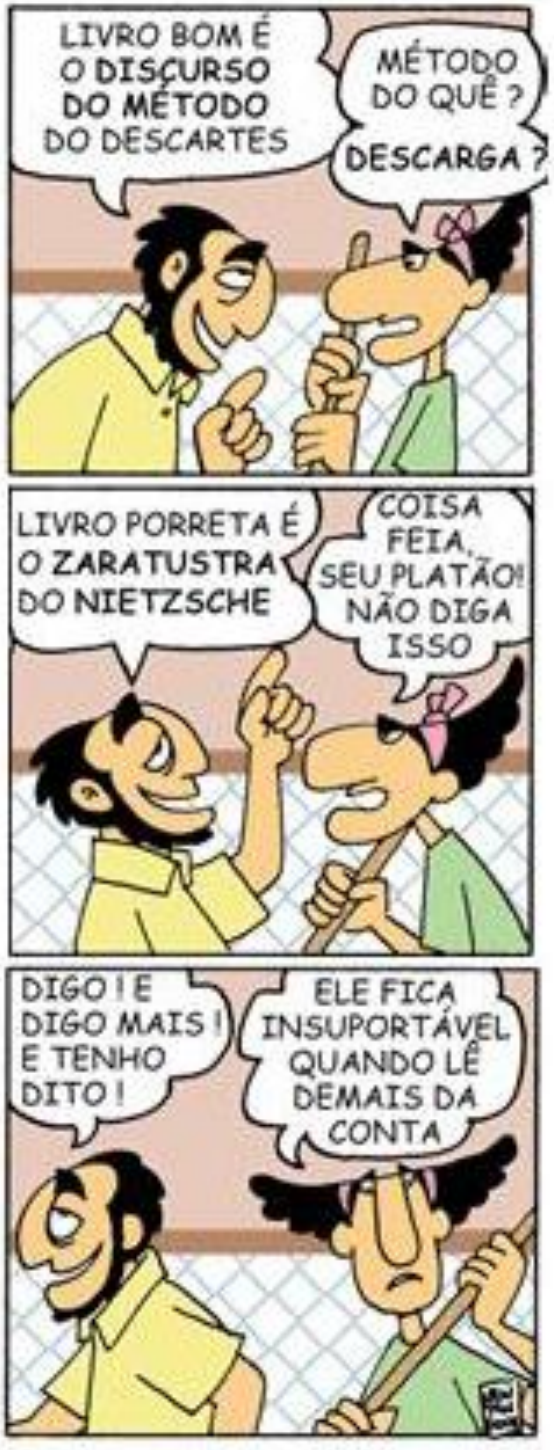

ESCOLA DE COMUNICAÇÕES E ARTES

Doutorado em Ciências da Comunicação

Teoria e Pesquisa em Comunicação 


\title{
Capítulo 3
}

\section{Leitura}

\section{Isaurau: o conto da sereia Izaura}

\begin{abstract}
Se na metade do século 12 a leitura silenciosa tornou-se popular por causa da tradução do texto em código alfabético, no 21 retomou-se com mais afinco a necessidade da leitura que vai além de somente decodificar palavras ou assimilar informações. Ler também pode ser um momento de entusiasmo, de conflitos, de transformações, de impulso, enfim, de movimento. Dentro do roteiro de nossa viagem por esse doutorado, tentaremos perceber porque a leitura que leva em conta a voz, a melodia, o ritmo e os gestos parecem diferenciar daquela que se assemelha a exercícios didáticos feita somente com o intuito de adquirir conhecimentos rápidos para cumprir um protocolo: o estudante apreende informações e o professor, a instituição emite-lhe uma pontuação de acordo com seu desempenho. Conseguidos tais "pontos", se esquece tudo. Partiremos, então, da concepção de que a linguagem vai além da razão pura; é experiência, um lugar de formação e transformação do sujeito. A partir dessa concepção descreveremos algumas atividades de leitura realizadas em saraus no período de 2004 a 2008, inspiradas em textos de autoria da coleção São Paulo de Perfil, realizadas em escolas particulares, públicas, bibliotecas e espaços comunitários. Com essa descrição, se fará uma reflexão sobre leituras em voz alta, leituras dramatizadas, leituras prosódicas que levem em conta o ritmo e a melodia.
\end{abstract}

Izaura não lê, encena (ou seria incorpora). Interage com o texto não apenas com os olhos, mas com o corpo inteiro. Não estamos falando (ainda) em troca de gêneros, do livro verbalizado para o teatro, dança ou cinema; mas da proxêmica, um sutil jogo de distâncias - ora perto, ora longe - que se entretece entre Izaura, o público e os espaços (físicos, extrafísicos, metafísicos). Este jogo soma significados aos fonemas, às palavras pronunciadas em voz alta. As técnicas lembram as de contadores de história, mas neste caso o texto é decorado, 
memorizado e depois contado. O sarau com a Izaura é sempre norteado por uma escrita grafada em papel, com pequenas anotações em lápis, sem edições no texto original do autor - cortes propositais, porque de vez em quando, como tudo está no frescor da acontecência, escapa-lhe uma palavra, um parágrafo pode ser esquecido. Não é tão somente uma leitura em voz alta com a decodificação dos fonemas, nem dramatizada quando ganha maior importância o desenvolvimento da fala do 'leitor-mor', (sua) postura diante do público ou (seu) conhecimento do espaço cênico; da leitura surge a cena sem recursos cênicos, É o Isaurau, um espetáculo sem ser espetaculoso. Insinuando cenas, com pequenos gestos, sutis mudanças na entonação da voz, Izaura constrói um lugar de interação entre autor e leitor. Ou seriam leitores, uma vez que Izaura divide seu olhar entre as escritas e a recepção da 'visu-audiência'. Se alguém está disperso faz um gesto mais brusco, se há uma intervenção de outra fala faz uma interrupção silenciosa, se encontra um olhar de monotonia faz um suspense. Nada de regras de como estimular a 'platéia', e sim uma forma intuitiva e inteligente de também responder a cada manifestação dos leitores. É desta maneira que o vapor do texto vai gradativamente se liquefazendo, solidificando na leitura de Izaura. A cada palavra, cada frase, parágrafo, ela reinventa as escritas, não apenas sob suas inferências e compreensão da realidade (conforme o pouco que pudemos conhecê-la). Além de, em si mesma, incorporar o texto, em seu Isaurau a recepção estética sempre é uma (boa) preocupação, compartilhada, sem uma transferência de responsabilidade e escolhas para o outro. Não se pergunta explicitamente sobre o agrado da leitura em curso, mas a atenção, a experiência e a sensibilidade de Izaura estão ávidas pela manifestação de indícios (que seja) de 
uma semente de transformação no leitor-ouvinte. O que estava disperso de repente se concentra. Se decidir sair, também nesta decisão pode se constatar uma mudança. Um brilho no olhar outrora dominado pela revolta, tédio transformado em interesse, um despertar de um sentimento de revolta, um susto. Transformações que valem o a to de ler ainda que aconteçam por alguns segundos. Há de se admitir a existência de algo peculiar em Izaura que contribui na 'animação' dos leitores. Não sei se sua risada, a voz ligeiramente rouca, a idade, o olhar lacrimejante, a docilidade da feição, a bruteza dos movimentos dos braços, a simpatia, a sinceridade, a firmeza das palavras, a vacilação da voz enganada pela salivação, quando não excessiva falta-lhe a humidificação da boca. Se isto ou aquilo ou a combinação de tudo, não sei. Izaura participou de vários saraus comigo e semigo, e a descrição dos Isauraus pelos presentes é sempre muito parecida: encantador, dizem. Quando realiza um sarau, Izaura não se transfigura em nenhuma personagem, seja na incorporação dos protagonistas das histórias que lê, seja numa personificação artística com uso de nome fictício. Nos saraus Izaura é Izaura, e através dela a leitura de um texto ganha um sabor diferente. Como as sereias, Izaura encanta. Não através do canto, mas pelo conto. E a pergunta a ser feita é: se isaraus pudessem se tornar um estilo, como encantar as pessoas com um texto lido em alto e bom som?

\begin{tabular}{|l|}
\hline $\begin{array}{l}\text { Encantar } \\
\text { do latim, incantare. }\end{array}$ \\
\hline $\begin{array}{l}\text { Verbo transitivo: exercer encantamento em. } \\
\text { Seduzir, enlevar, maravilhar; atrair. }\end{array}$ \\
\hline $\begin{array}{l}\text { Verbo reflexivo: tomar-se de encanto; enlevar-se; maravilhar-se; } \\
\text { Desaparecer, tornar-se invisível. }\end{array}$ \\
\hline $\begin{array}{l}\text { Encantado (adjetivo): que tem encantamento; enfeitiçado; } \\
\text { enlevado; seduzido; fascinado. }\end{array}$ \\
\hline
\end{tabular}


Cobras são encantadas, mas este é um artifício de hipnose. Competentes domadores, como em $O$ Encantador de Cavalos - livro de Nicholas Evans cinematografado e dirigido por Robert Redford - o fazem por técnicas de domesticação. Seriam esses os segredos da nossa Encantadora de Leitores: hipnose e domesticação. O processo parece simples como uma brincadeira de criança. Juntam-se letras e formam-se palavras que juntas formam frases, parágrafos, textos. Parece. Como o texto pode transportar, suas palavras causarem arrepios, a frase ficar retumbando nos nossos ouvidos. Que magia é essa? Que encantamento faz com que as palavras, escritas, lidas, faladas, tão efêmeras, sem sustância, provoquem tantas reações em toda gente? Como algo pode se tornar eterno justamente por sua absoluta fragilidade. Afinal, porque escrevemos? Porque lemos? Que poder é este que a palavras exercem sobre nós?

Um preso escreve uma mensagem em um pedaço de papel-pão, quando não no higiênico, dá ao homem que passa no corredor e pede que esta chegue até o juiz. O advogado faz uma defesa em dezenas de páginas em uma petição. Âncoras do telejornal apóiam-se em apontamentos escritos numa folha de papel. A empresa espalha escritas publicitárias de seu produto pela cidade. Os amigos combinam um encontro por meio de torpedos no celular. O médico diagnostica e prescreve a receita para o paciente. A mesma receita será lida na farmácia. $\mathrm{O}$ paciente receberá o remédio com uma embalagem toda escrita e uma bula a tiracolo. O cliente tira o extrato do banco que já tem por escrito, em contrato, as regras de seu relacionamento com o cliente. No restaurante está lá, o cardápio, escrito. No tornozelo, na nuca ou no antebraço, uma tatuagem. No muro da escola, na porta do banheiro público está lá uma mensagem pra um leitor 
anônimo. Recorde de bilheteria no cinema o filme tem pés firmes em um roteiro escrito. Na locução acelerada do locutor de rádio, as palavras se esparramam e disputam por um espaço na cabeça dos ouvintes. As palavras, em qualquer "estado físico", nos transformam em verbo para que outra pessoa possa se apropriar de nós. É na palavra que nos fazemos humanos, com identidade, cheiro, cor, ritmo, textura e sabor.

Independente de religiosidade e de crença, numa releitura mítica das escritas da Bíblia, ainda o livro mais lido do mundo, poderíamos dizer que essa magia da palavra aconteceu na Criação. De escuro e sem forma, o mundo tornouse mundo porque o Criador externou suas imaginações e pensamentos artísticos em palavras. A gênese mítica está registrada em narrativa no capítulo de Genesis da Bíblia.

No princípio criou Deus os céus e a terra. E a terra era sem forma e vazia; e havia trevas sobre a face do abismo; e o Espírito de Deus se movia sobre a face das águas. E disse Deus: Haja luz; e houve luz.

E utilizando-se de palavras o Criador continuou a externar sua criatividade separando a luz e as trevas e criou palavras para dar nomes à suas criações.

E Deus chamou à luz Dia; e às trevas chamou Noite. E foi a tarde e a manhã, o dia primeiro.

Utilizando da ferramenta-palavra fez surgir coisas que não existiam e com as mesmas, foi designando os limites da existência. Conhecedor deste poder da 
palavra, o Criador transformou o que era sem forma e vazia em algo; em algo que achou bom.

E viu Deus tudo quanto tinha feito, e eis que era muito bom; e foi a tarde e a manhã, o dia sexto.

A narrativa do capítulo primeiro de Gênesis é atentar que tudo o que o Criador criara existia na esfera da palavra pronunciada, mas ainda não existia de fato:

E toda a planta do campo que ainda não estava na terra, e toda a erva do campo que ainda não brotava; porque ainda o Senhor Deus não tinha feito chover sobre a terra, e não havia homem para lavrar a terra.

Foi então que o Criador resolveu escrever. Escreveu o homem no barro e quis que esta escritura tivesse vida. No segundo capítulo de Gênesis fica perceptível que somente depois da palavra escrita se fazer viva através do ser humano, macho e fêmea, foi aí que todas as criações até então em palavras se manifestaram em vida, em existência, no chamado Jardim do Éden.

E formou o Senhor Deus o homem do pó da terra, e soprou em suas narinas o fôlego da vida; e o homem foi feito alma vivente. E plantou o Senhor Deus um jardim no Éden, do lado oriental; e pôs ali o homem que tinha formado.

E o Senhor Deus fez brotar da terra toda a árvore agradável à vista, e boa para comida; e a árvore da vida no meio do jardim.

O mundo, obra-prima do autor-Criador, mesmo já estando delineado em palavras, somente ganhou existência a partir de um ser, a semelhança do Autor, 
com a capacidade de ler e dar significados a estas criações. O Criador precisou de um leitor para dar vida e existência para sua obra-Criação. Com essa releitura da gênesis poderíamos dizer que, mitologicamente, Adão foi o primeiro leitor conhecido no mundo. E o Criador viu que apenas uma leitura do mundo não era bom; não era bom que o homem estivesse sozinho. Criou então uma adjutora, um segundo leitor, diferente do primeiro. Foi através deles, Adão e Eva, que a Criação tornou-se Mundo, e um mundo plural. Inicialmente plural de dois, mas que foram se multiplicando potencialmente.

Deus os abençoou, e Deus lhes disse: Frutificai e multiplicaivos, e enchei a terra.

Ainda de acordo com as escrituras hebréias, a importância da escrita também se fez necessário para solidificar, tornar autêntico e perpetuar em memória a vontade de Deus. No livro de Êxodo está registrado:

Então disse o Senhor a Moisés: Escreve isto para memória num livro, e relata-o aos ouvidos de Josué.

E antes mesmo da invenção da tipografia e da impressão, redigiu-se, senão o precursor, um dos primeiros livros da história da humanidade para eternização em palavras escritas dos dez mandamentos.

Independente do suporte e dos instrumentos utilizados para o ato da escrita (que podem ser, a princípio, possibilidades infinitas) é inegável esta habilidade que herdamos para transformamos o que era "nada" em algo com algum sentido. A partir do Criador número 1 se fez várias réplicas de criadores: os seres 
humanos. E a palavra se fez uma manifestação da habilidade humana de criação. Escrever e ler faz parte de um eterno ciclo de produção criativa, simbólica. Através dela estamos a todo instante construirmos, desconstruirmos e reconstruirmos simbolicamente o mundo em que vivemos.

Se enxergarmos a necessidade da escrita embutida a uma intrínseca necessidade de leitura, há de se considerar a dificuldade de reprodução ipsis litteris da palavra falada. Sob esta ótica, a escrita daria à palavra a condição de durabilidade enquanto que a fala seria mais 'volátil'. Quem sabe esta não tenha sido uma das razões que motivou a contribuição deixada por Moisés na Tábua dos Dez Mandamentos. Esta permanência da palavra escrita está condicionada aos instrumentos, suportes e até mesmo as formas de circulação deste texto. A escrita poderia também estar ligada a sua própria existência e não necessariamente a sua durabilidade. Quantas vezes negamos esta durabilidade desfazendo-o do nosso texto, rasgando, queimando ou trancafiando o diário? Quantas palavras ditas, sem nenhum registro, ressoam em nossas vidas até a nossa eternidade. A palavra não seria um simples aspecto da condição humana, mas a origem e até mesmo a causa desta condição. São pelas palavras que temos um certo poder de antecipação e de reprodução do que já foi, e esta capacidade nos distinguem da condição meramente animal. As palavras são bem mais que um bornel de conceitos e abstrações; elas carregam o futuro, alteram o passado. Estamos muito mais na linguagem do que ela em nós, e esse espaço simbólico de signos tem possibilidades infinitas de ocupação.

Em 1947, o escritor britânico Eric Arthur Blair sob o pseudônimo George Orwell (conhecido por sua obra 1984), escrevia o ensaio Why I Write, momento 
em que elenca quatro motivos individuais e, oxalá, por suas pretensões, coletivos, da necessidade de escrita. Por puro egoísmo, diria ele, referindo-se ao desejo humano de se parecer esperto, de ser falado, de ser lembrado até mesmo depois da morte - o universal e histórico desejo humano da eternidade. Também por um entusiasmo poético, vindo do prazer que temos da estética, da beleza e do grotesco, do impacto de um som, do ritmo, de uma boa estória, da disposição das palavras favoritas, da construção de um visual com tipografias e margens - a mágica e o poder da transformação, da criação, do poder que tem o meu Eu de fabricar algo, a mágica autoria. E voltamos ao encantado poder de criar representado na metáfora da Criação. Mas se há na palavra um poder de criar, o contrário também pode ser verdadeiro; ela pode, filosoficamente, destruir. Refletiu Yves Bonnefoy:

Se a humanidade deve perecer [...] isso será por falta de termos sabido melhor utilizar a linguagem; por falta, também, de ter preferido na linguagem as propostas fruto de reflexão, as capacidades de sublimação, em vez de escolhermos as pulsões cegas daquilo que resta em nós de animal.

Ainda nesta busca interna, aprofundada e compartilhada do desejo da escrita, Blair (ou seria Orwell) continua explorando possíveis fatores. Cita um terceiro fator que denomina impulso histórico referindo-se ao anseio de descobrirmos e entendermos os fatos e preservá-los para uso da posteridade, transmitindo o conhecimento para as gerações futuras. Segundo o autor, a escrita teria ainda uma quarta motivação, o propósito político, o desejo de sermos parte de um todo, de empurrar o mundo numa certa direção, transformando as idéias 
das pessoas sobre o tipo de sociedade pela qual se deve lutar. A política a qual se refere Blair tem um sentido lato, com uma função integradora do social, de socialização e engajamento dos indivíduos. Em todas as motivações relatadas por Eric Blair - 1. egoísmo, 2. entusiasmo poético, 3. impulso histórico e 4. propósito político - está implícita a idéia da existência de um leitor, assim como percebeu o primeiro autor-Criador quando criou o homem-leitor. Escrevemos porque na outra ponta do texto haverá um leitor que em algum momento, ou não, se inspirará naquela criação, naqueles dizeres. Quando negamos a existência de um texto, estamos na verdade negando a leitura do mesmo. É possível desvincularmos a escrita da leitura, o agente escritor do leitor? A quem pertence a palavra? Quem lhe dá poder? Quem lhe dá significado? No mito da Criação do Mundo até mesmo o Criador, ainda que feito tudo em palavras, precisou da presença, existência, de um leitor - o homem - para que suas criações se tornassem 'real'. Porém, há de se ponderar que apesar do mundo se formar através da força das palavras - Haja luz, e houve luz - para que haja uma criação é necessária uma vontade: a vontade de criar algo.

A palavra não cria as coisas do nada. Mas retira, sim, as coisas da sombra, do esquecimento, do exílio, ou do passado, ou do futuro. As palavras são embaixatrizes da realidade. Elas trazem para o nosso meio todo o universo. Trazem reinos, aves exóticas, estrelas do céu, flores de aromas impensáveis, anjos, demônios. Falamos a palavra, e o universo responde ao chamado, e os mortos ressuscitam, e nós mesmos nos iluminamos.

Gabriel Perissé, 2008 
A escrita por si só pode até ter um propósito de não ter propósito: um rabisco em bloco de notas, por exemplo. No entanto, quando há a consolidação (significante) de uma idéia humana (significado), o rabisco passa a ser uma representação de algo interpretável (leitura), torna-se signo. Não um signo pronto, dado, acabado, e sim um signo metamorfoseado conforme àquele que lhe faz acontecer, conforme seu interpretante (leitor). Como a vida, a leitura faz-se pela variedade de probabilidades de conexões e não de coisas. Uma partícula é, essencialmente, um conjunto de relações que se estendem para se conectarem às outras coisas, e estas coisas também são conexões, e assim por diante. A física atômica mostrou-nos que a natureza essencial da matéria não está nos objetos, mas nas conexões. As relações formam a matéria, a vida, o universo, o signo. Este conjunto sígnico - significante, significado e interpretante - não é um conjunto isolado, ao contrário, está em constante relação sistêmica, comungam, comunicam-se com outros conjuntos e variáveis externas, contextuais, situacionais, diz-se que este é o Signo da Relação. O signo também não é algo (objeto) e sim uma variação de probabilidades de nexos, relações, conexões texto - entre signos, seres humanos, situações, suporte da escrita, tempo, espaço e outras variáveis. Dessa relação epifânica (leitura) nasce o significado.

O texto - cosmo de signos - vai além da intenção do autor e a execução dessa intenção (ou não) através do leitor. Os significados de um texto somente se manifestam através da leitura, um complexo de relações estabelecido por ação dialógica. A leitura relaciona, ainda que virtualmente, produtor, consumidor do texto e o mundo que os permeiam. Esta rede sistêmica inicia-se no autor-escritor, que poderá prever seu interlocutor, os movimentos do leitor idealizado no texto. 
Porém, o texto somente se contemplará na leitura do Outro. Pela perspectiva da ação dialógica [refletida por Paulo Freire (FREIRE, 1987), como uma ação cultural norteada por quatro princípios: a co-laboração (probabilidades de conexões), a união para a libertação (transcendência), a organização (criatividade) e a síntese cultural (transformação), o texto é o encontro de duas, também complexas, construções: aquela que está a princípio concluída na criação do escritor, e outra construção do texto vivo que está em constante elaboração por meio dos leitores e das infinitas possibilidades de leitura. Como na dança cósmica do universo em que as partículas se colidem, interagem, criam e destroem outras partículas, estamos em meio a uma permanente dança de criação e destruição de significados. Esse movimento do leitor/escritor enquanto autores - autor-escritor e autor-leitor - é a dança dialógica de (re)construção de sentido. Daí insistirmos no paradigma do Signo da Relação enquanto proposição da reflexão sobre o ato da leitura, e ainda sob a ótica da Comunicação, comunhão, relação em seres. Da mesma forma que não há dialogia se não houver uma interlocução entre leitor e escritor mediada pelo texto que os unem (Bakthin, 1986), também a comunicação só existe na reciprocidade do diálogo e isto é central na produção de sentidos em leitura e escrita. Ao procurar compreender o que está pressuposto na construção de sentidos, percebe-se a importância de considerar o processo de escrita/leitura não somente sob às descrições dos níveis linguísticos necessários ao domínio da língua ou às considerações que privilegiem o produto final, mas como um processo em que o sentido vai se construindo a partir da dialogia entre interlocutores (leitores e escritores) e os textos entre si. 
Se os sentidos dos textos se manifestam na relação entre sujeitos, o autor não é dotado do conhecimento, da palavra; e nem mesmo o leitor. Então, quem se adapta a quem? Um se adapta ao outro. Eles co-evoluem. A evolução é então uma conversa em progresso. O saber constrói-se na relação. Não naquela involuntária, mas na relação em que os sujeitos se interagem e de fato acontece a dialogia, a reciprocidade, a comunicação. Os sujeitos-autores surgem tanto no ato da escrita quanto no da leitura, e o significado, o saber, não está nem em um, nem em outro, e sim nos vínculos que este faz com o mundo, com outros textos, com os sujeitos que o circundam. Quando escrevemos e lemos estamos cosmicamente construindo sentidos, estamos praticando um diálogo. Escrever ou ler é uma atividade de fazer conexões de sentidos, de encontrar nexos, montar um quebra-cabeça. A dialogia aconteceria quando os elementos linguísticos dos textos, por meio dos sujeitos, seja ele o escritor ou o leitor, combinam-se interativamente para criar a textualidade, isto é, aquele ato que faz um texto ser um texto e não um amontoado de palavras disponíveis ao processamento do leitor. Deste ponto de vista o texto seria o meio, o elo que liga metades complementares - escritor e leitor -, o lugar onde o leitor e escritor se encontram e podem interagir e dialogar, e a longa distância.

O texto é um produto grafado/escrito que continua, ad eternum, em construção, que varia quanto à forma e função de acordo com o escritor (experiências anteriores, percepções do interlocutor, conhecimento do tópico e propósito de comunicação) e de acordo com o leitor (suas experiências anteriores, percepções, conhecimento do tópico e propósito da leitura). Os textos são processados pelos leitores numa interação entre leitor e texto e igualmente 
entre o leitor e o escritor, numa relação triangular decorrente do modo pelo qual os aprendizes se engajam, contribuem e fazem conexões com os textos. Como autores, os leitores dão um propósito às suas leituras, podendo este mudar a cada vez que voltarem ao texto para outra leitura. Assim como o leitor, o escritor também desempenha um papel similar, ou seja, o escritor ao mesmo tempo em que é um autor que escreve para um leitor (real/virtual) individualmente ou para um grupo de pessoas que compartilhem objetivos, ele mesmo é o primeiro leitor de seu próprio texto.

Uma das vantagens de uma visão integrada de leitura e escrita como processos é a reciprocidade no crescimento intelectual dos aprendizes nas duas habilidades. O argumento a favor dessa visão integrada dá uma dimensão social à leitura e à escrita. De fato, em três de anos de pesquisa, reflexão e laboratório, aprendi que os motivos da escrita, assim como da leitura, são tão múltiplos quanto múltiplos são seus autores e leitores. De todas as reflexões contidas neste capítulo podemos considerar que a escrita e a leitura seriam atos concomitantes, atividades coexistentes. De fato, a combinação de códigos parece ser uma ação involuntária do nosso sistema nervoso, moldado pela educação. Porém a atribuição de sentidos e significados não parece ser uma atividade mecânica do corpo humano. A palavra torna-se então uma ferramenta de reapresentação e simbolização do mundo, de transcendência.

A leitura, até então oral e ágrafa, amplia-se, oferece-nos outras perspectivas para ler o mundo. Dá-nos condição de encontro com novas maneiras de interpretar a sociedade, seus conflitos $e$ a própria natureza humana. A partir de então, mundo e palavra permearão constantemente nossa leitura e inevitáveis serão as 
correlações, de modo intertextual, simbiótico, entre realidade e ficção (SILVA, 2003:17).

Mundo e palavra. Palavra e construção de outro mundo, o texto. Além de perpetuar idéias - como metalinguisticamente ocorre nesta pesquisa quando nos predispomos a fazer uma pesquisa mais acurada de algo a fim de conhecê-lo melhor, buscando definições, conceitos, significações, frases, textos, livros -, a escrileitura é uma forma de ser humano se confortar diante do caos, se autoorganizar, estabelecer novos e infinitos cosmos. Escrilemos gibis, cartas, poesias, romances, jornais, textos científicos, textos literários, textos; em livros, madeira, internet... porque precisamos decifrar o desconhecido, transcender. Escrilemos para multiplicar nossas possibilidades uma vez que "na vida real", ainda por limitações físico-químicas, não temos condições de "conhecer" tantas coisas e tantas pessoas com tanta intimidade quando acontece por meio da escrileitura. Ler é expandir-se para todos os tempos e espaços; reunir em si mais lembranças e conhecimentos do que a idade que realmente temos nos proporcionaria. Talvez o motivo de lermos é porque queremos nos apropriar de outros pensamentos, de outras idéias, que por vezes consideramos muito melhor do que as nossas. Lemos para nos comunicar; para nos informar, adquirir mais conhecimento, saciar nossa sede do saber. Por recreação, passatempo, aventura, desafio, por obrigação. Quem sabe? Cada um sabe por que e para que lê. Não importa. A verdade é que este motivo individual da leitura é uma descoberta, embora a construção do sentido seja coletiva. E é esta busca e descoberta que realmente importa. De tudo, podemos dizer que ler é uma descoberta que nos faz olhar o mundo e enxergar dentro e além do nosso interior, de nós mesmos. $\mathrm{E}$ ao que muitos dizem que a 
escrileitura vem se tornando uma atividade rara, há de se pensar que ler é a tarefa do passado, presente e do futuro, porque é com esta atividade que as pessoas realizam uma espécie de auto-educação constante, desenvolvem de modo autônomo sua competência.

Podemos escreveler por hábito, por vaidade, para ganhar dinheiro, porque é o nosso ofício, para cumprir prazos, por gosto, para ser amado, para despertar algo em outrem, para comover, assustar, instigar, como forma de passatempo, para treinarmos a escrever cada vez melhor. Neste capítulo eu escreveleio para compreender porque escrevelemos.

É na relação do humano com o mundo, na dialogia da pulsão da vida e da pulsão da morte (CARVALHO, 2002: 170) que surge o encantamento. Viver é ontologicamente encantador. Somos nós, seres humanos, que escolhemos - a cada ato, circunstância, objeto -, entre ordinário e extraordinário. Como nos conta Rubens Alves (2006):

Isso tudo está relacionado com a educação dos sentidos. Ao longo da vida, a gente vai ficando cada vez mais imbecilizado em relação aos sentidos. As crianças vêem. Elas se encantam com o mundo. Quando minha neta tinha um ano de idade, a mãe dela fez uma festa de aniversário, com bexiga colorida, decoração e tudo mais. No meio da festa, a menina sumiu e, quando a encontramos, estava no gramado, encharcado, como vestido novo molhado. Ela segurava nas mãos uma coisa mil vezes mais interessante que a festa: uma minhoca. Ela estava absolutamente encantada.

Uma vez, na época em que eu atendia como psicanalista uma paciente me disse: "acho que enlouqueci". Eu estava procurando fazer com que ela me contasse sobre este enlouquecimento e ela me disse: "gosto muito de fazer comida para os meus amigos. Vou para a cozinha, preparo um bolo e adoro fazer isso. Mas, alguns dias atrás, aconteceu uma coisa. 
Fui cortar cebolas - e já cortei centenas de cebolas antes -, e na hora em que cortei a cebola e olhei para ela, percebi que nunca tinha visto uma cebola. Aqueles anéis concêntricos, lindos, e a luz incidindo naqueles anéis perfeitos. E tive a impressão de que estava vendo o hall de catedral gótica. Acho que estou ficando louca."

Nesse momento, fui até a estante e peguei um livro de Pablo Neruda, Odes Elementares, e li um poema: "Ode à cebola". Poetas não escrevem sobre cebolas, mas sobre rosas. Quando damos rosas para uma mulher, todas dizem a mesma coisa: "Que lindas", agora dê um buquê de cebolas! Olha o que Neruda fala da cebola: "Rosas de água com escamas de cristal". As cebolas, daqui pra frente, não serão mais as mesmas. Esse é um dos poderes da poesia. Ela abre os nossos olhos. Adélia Prado diz: "Deus de vez em quando me castiga, me tira a poesia". Olho para a pedra e vejo uma bola. O cientista olha para a pedra e vê uma pedra. O poeta olha para a pedra e vê outra coisa. Por exemplo, "Tinha uma pedra no meio do caminho...".

Rubens fala em educação dos sentidos e na imbecilização ao longo da vida; Luís Carlos Restrepo, em Direito à Ternura, critica o que chama de analfabetismo afetivo resgatando a palavra splacnisomai do original grego do Novo Testamento. Essa palavra corresponde à conjugação de um verbo desaparecido no século II a III de nossa era e que hoje poderíamos traduzir literalmente como 'sentir com as tripas'. Pensei no ato de encantamento sob esses provocantes textos. Sentimento visceral, sentir com as tripas. É ainda Restrepo que ressalta a essência do humano e a qualidade que nos distancia da inteligência artificial: a capacidade de se emocionar, de reconstruir o mundo e o conhecimento a partir de laços afetivos que nos impactam.

Coincidentemente encantar, encanto tem algo de dança cósmica (como foi citado), uma troca contínua de matéria e energia, de transformações. Até 
mesmo a morte é a transformação da matéria. O universo é feito de harmonia de sons e relações. As relações formam a matéria, o significado. O acorde, a melodia, o significado é a relação entre a duração do som e sua frequência. Para haver dança (se significados na escrileitura) precisa haver música, e a música não se constitui apenas de som, mas também de silêncio. Do nada (vazio e sem forma) ao significante, do silêncio à palavra, o ser falante se introduz no universo da linguagem, humanizando-se. Só o texto pode fixar pelo ato de escrita o hiato que se abre entre o corpo e a linguagem, entre o dito e o não dito, entre o sujeito e o eu (dialogia).

Nos Isauraus, a leitura em voz alta feita por Izaura é sempre uma composição musical. A brincadeira dançante com os sons das palavras, as entonações, o silêncio, têm o efeito de uma canção de ninar. Curioso saber que no Ocidente comum era a leitura que se realizava em voz alta, pois a leitura silenciosa tornar-se-ia usual apenas no século 10. Ainda que a leitura silenciosa fosse ocasionalmente aplicada, até então ela não tinha podido entrar no uso corrente, porque cada linha era formada por uma sequência ininterrupta de letras, sem espaços vazios entre as palavras escritas, não distinguia maiúsculas e minúsculas e nem pontuação. O leitor (privilégio de poucos), alguém de grande prática, encarregava-se do ritmo da leitura. Os próprios copistas (pessoas que copiavam manuscritos, antes da invenção da imprensa), ao realizarem seu trabalho, faziam-no em voz alta. Antes do século 10 a leitura era sempre um ato público.

defatonãoerapossivellersenãopronunciandoasfrasese mvozal taeouvindoosomparaentender hesosignificado 
Uma sentença destinada a ser transcrita era um ditado: era pronunciada segundo as regras da rítmica prosaica clássica. Identificado o ritmo de quem ditava podia-se ler sem problema. Mas o significado não surgia da página enquanto não fosse lido à viva voz. A separação entre as palavras foram introduzidas com fins didáticos; serviam para facilitar a aprendizagem do vocabulário. Os espaços entre as palavras tornaram possível o copiar em silêncio. Assim, o amanuense podia copiar os textos palavra por palavra, ato que no passado não teria sido possível transcrever ao simples olhar linhas formadas de uma sequência ininterrupta de 30 a 40 letras minúsculas. Com a leitura silenciosa foi vista com receio, pois sem testemunhas tornou-se possível a leitura de livros obscenos e hereges. A leitura em silêncio propiciou o sonhar acordado, o perigo de acídia - o pecado do ócio (MANGUEL, 1998). Havia ainda outro 'perigoso' na leitura silenciosa:

...um livro que pode ser lido em privado já não é suscetível de clarificação imediata ou de leitura guiada, condenação ou censura por um ouvinte. Leitores assim independentes tornavam-se obviamente... perigosos - como viria a provar o movimento protestante que, no século XVI, defendeu que toda a gente tinha o direito de ler a palavra de Deus diretamente, sem testemunhas nem intermediários.

De fato, sistematizando todos os problemas discutidos hoje em relação aos leitores - leitores-cidadãos - de alguma forma estão relacionados com o silêncio e não com a musicalidade (decodificação de grafias e fonemas, de sons). Dos saraus-laboratórios realizados durante esta pesquisa, verifica-se uma dificuldade 
de compreensão no que foi silenciado nos textos, da substância não-dita do signo. Talvez porque na alfabetização, no ensino contemporâneo da leitura, o silêncio não é compreendido como um processo de construção da significação. Observase que na leitura silenciosa os sujeitos aprendem a repetir sentidos cristalizados sobre leitura, não se instaura o princípio de autoria, os leitores-reprodutores não controlam os sentidos produzidos, tampouco os historicizam. Há, portanto, discordância de compreender o silêncio - e não as entrelinhas como pode se confundir - como linguagem, e talvez sob esta questão seja possível compreender melhorar as diferenças entre televisão, cinema, games e o livro.

Em As Formas do Silêncio Eni Orlandi reflete acerca das dificuldades em escrever (e acrescento ler) um livro tendo como desafio a tessitura do silêncio, apresentando os sentidos do silêncio, da articulação do dizível com o indizível. Para ela há um modo de estar em silêncio que corresponde um modo de estar no sentido; as próprias palavras transpiram silêncio. $\mathrm{O}$ estudo do silenciamento (que já não é silêncio, mas colocar-se em silêncio) nos mostra que há um processo de produção de sentidos silenciados que nos faz entender uma dimensão do não-dito absolutamente distinta da que se tem estudado sob a rubrica do implícito. Para o autor o sentido do silêncio não é algo ajuntado, sobreposto pela intenção do interlocutor: há um sentido no silêncio, tão variável quanto na sonoridade. Com isso, ele livra o silêncio do sentido passivo e negativo que lhe foi atribuído pela nossa cultura; assim, na História, o não-dizer está diretamente ligado à ideologia. 


\section{Capítulo 4}

\section{Escala epistemológica}

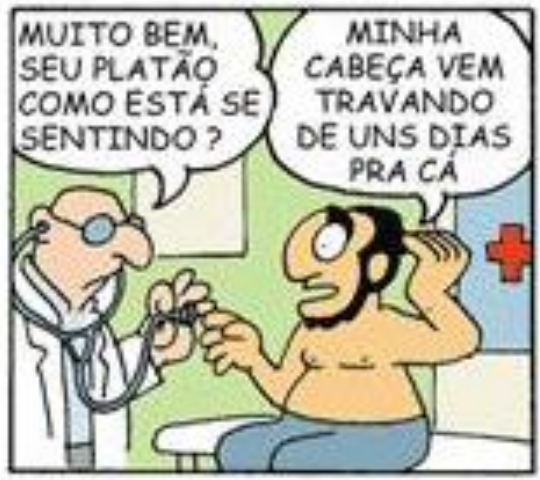

ACHO QUE ANDEI LENDO DEMAIS ! CHEGO A TER DIFICULDADES ATE PARA RACIOCINIOS BANAIS..

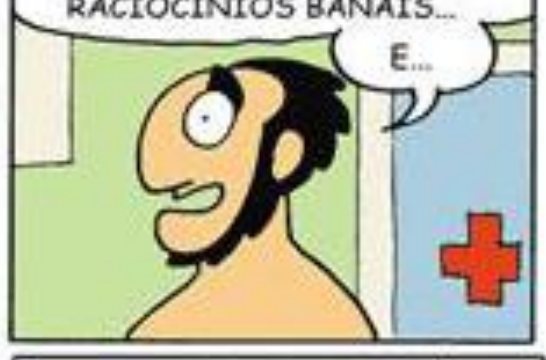

MAS, AFINAL, QUEM É O SENHOR ? O QUE ESTOU FAZENDO AQUI ?II

ESCOLA DE COMUNICAÇÕES E ARTES Doutorado em Ciências da Comunicação Teoria e Pesquisa em Comunicação 


\title{
Capítulo 4
}

\section{Leitura}

\section{Escala epistemológica}

\begin{abstract}
No pacote turístico a qual este doutorado convida seus honrosos leitores a uma viagem para conhecermos mais sobre as questões que envolvem a leitura, nosso voo fará sua primeira escala no mundo da epistemologia. Diante de uma fotografia ("real e imutável") apocalíptica a qual nos é apresentada sobre as dificuldades para formar leitores nos mais variados ambientes - escolar, principalmente - vamos tentar pintar um quadro (com toda plasticidade a que nos é permitida) buscando cores, formas e traços epistemológicos a fim de construir desconstruindo as fundamentações teóricas, conscientizadas ou não, a fim de desenhar concepções que rompam com o modelo hegemônico impregnado de vestígios positivista e mecanicista.
\end{abstract}

Em 2003 a pauta na agenda social dos países latino-americanos foi intencionalmente provocada por decisão política quando a Cúpula dos Chefes de Estado dos Países Ibero-Americanos agendaram o Ano Ibero-Americano da Leitura para 2005. Enquanto isso, em 2004 sai a publicação dos dados do Inaf (Indicador de Analfabetismo Funcional) encomendada pelo Ministério da Educação apontando que apenas $25 \%$ dos brasileiros compreendem o que lêem. Em 2005, é a vez da avaliação nacional da educação brasileira denominada Índice de Desenvolvimento da Educação Básica (Ideb) mapear a qualidade de ensino em 4.350 municípios brasileiros obtendo uma baixa média nacional (3,8 na $1^{\mathrm{a}}$ fase do ensino fundamental, e 3,5 na $2^{\mathrm{a}}$ fase). No mesmo ano o Programa Internacional de Avaliação de Estudantes (PISA) divulga pesquisa onde o Brasil ficou em último lugar, referindo-se à compreensão da leitura, apontando assim 
uma imensa dificuldade que o sistema de ensino brasileiro tem com a aprendizagem da leitura contínua, e não somente a alfabetização. Em todas as pesquisas e levantamento de índice concluía-se a falta de políticas de leitura interligadas não somente com o ato de ler em si, mas também com os gestos de leitura na educação brasileira no ambiente escolar e além da instituição escola. Antes de estimular mudanças metodológicas com políticas sociais de leitura é preciso a haver uma reflexão epistemológica que envolve não somente a concepção exclusiva de leitura, mas também está embebecida nas problemáticas do segregamento do conhecimento específico fragmentário e a consequente concepção de ensino reducionista "em que o que está em jogo, na maioria das vezes, é a memorização e a repetição, a mecanização e a previsibilidade (LEAL, 2002, p.322).

Seguiremos, não separadamente nem necessariamente na ordem de citação apresentada, a sugestão da pesquisadora Mirian Zappone (2001) que sintetiza as concepções de leitura abordadas pela pesquisa acadêmica em quatro linhas básicas: cognitivo-processual (ler é interagir com o texto), estruturalista (ler é “descodificar"), política-diagnóstica (ler é engajar-se) e discursiva (ler é produzir sentidos).

No bojo dos entendimentos sobre leitura compartilha-se no senso comum o ponto de vista que julga ser a leitura, num sentido mais amplo, o processo de interpretação dos estímulos sensoriais. Afirmar isso é dizer que leitura é tudo aquilo que ocorre nos terminais sensoriais quando estimulados externamente; uma definição que se confundiria com o conceito biológico de percepção nervosa. Será que os estímulos provocados por uma música, uma fala, uma superfície áspera, um cheiro, uma degustação de um alimento, fazem parte do que acreditamos ser leitura? Entre a captação e a percepção, interpretação do mundo há uma complexa rede de caminhos que por talvez por falta de outra compreensão mais completa podemos denominar de leitura. A percepção do mundo passa pela compreensão, a (re) ligação com seus elementos. 
Dentro desta acepção, ler significaria buscar semelhanças e contiguidades entre as coisas, pessoas, fenômenos, objetos culturais. Em outras palavras, a leitura seria um infinito jogo associativo do "entorno cultural existenciário, ao passo que religar substanciaria a tentativa de restabelecer ligações ou elos perdidos dentro de certos princípios de conexões com o mundo ao nosso redor, como num jogo dialógicodialética entre mundo exterior e percepção interiorizada do mundo" (QUADROS, 2009, p.74).

Os estudos que tentam fazer uma abordagem "puramente científica" sobre a leitura, como a psicologia cognitiva da leitura, limitam o recorte do objeto de estudo, a fim de não diluí-lo e perder o foco, na leitura diretamente ligada aos sinais gráficos. Assim, descrevem e explicam o conjunto das capacidades cognitivas, ou seja, as habilidades mentais e os comportamentos ligados ao sistema de tratamento da informação presentes não apenas nos seres humanos, mas em todos os seres do reino animal (MORAIS, 1996: 38). A abordagem da psicologia cognitiva é estritamente analítica. Decompõe o sistema e estuda a maneira com que esse opera na percepção e reconhecimento da linguagem, na seleção, avaliação, aquisição, memorização, organização, raciocínio, tomada de decisões etc. Como os estudos sobre cérebro estão repletos de incertezas (DAMASIO, 1995), a metodologia usada na análise da cognição humana é essencialmente experimental, observando-se e comparando-se performances de seres normais e patológicos em tarefas nas quais utilizam este sistema cerebral no ato da leitura, isolando-se uma destas capacidades cognitivas.

A pesquisadora Anna Maria Marques Cintra considera que foram as áreas das Ciências da Linguagem e da Psicologia que propiciaram uma mudança significativa nos estudos textuais e de hermenêutica, principalmente no último quartel do século 20, abrindo espaço para questões de leitura e produção textual. Para ela, foram os estudos da Psicologia, da Linguística e, em especial, da Semântica que suscitaram preocupações 
com estudos sobre a compreensão de textos que pode ser observada indiretamente, as pesquisas, ao mesmo tempo em que buscam aprofundamento no campo conceitual, investigam formas de medir a compreensão (Cf. LENCASTRE, 2003). Os modelos de análise levam em conta a compreensão do texto de duas formas: um processo aditivo de construção de uma representação proposicional interligada num todo coerente, denominados extração elementarista; e uma forma de compreensão menos dependente do texto, segundo a qual o leitor constrói desde o início da leitura uma estrutura mental holística do tipo de um esquema ou de um modelo mental, chamado extração holística (LENCASTRE, 2003: 11-2).

Um dos estudos que contribui para o questionamento do processo (mecanismo) que acontece durante a leitura com ênfase para a memória e armazenagem do conhecimento foram os estudos da Inteligência Artificial com a teoria dos frames ou teoria dos esquemas. Frame é um termo da área computacional, utilizada em estudos sobre Inteligência Artificial inspirada na armazenagem de dados do computador e transferida analogicamente para a armazenagem de conhecimentos na memória humana.

Segundo essa perspectiva, o nível de compreensão é diretamente proporcional ao grau de aproximação entre os conhecimentos veiculados no texto e os conhecimentos armazenados na memória do leitor. Quanto mais estreita for essa relação entre produtor e receptor, melhor será a compreensão. No entanto, mesmo com as melhores intenções e condições de comunicação, não se pode garantir que uma mensagem seja recebida pelo leitor assim como foi intencionado pelo produtor, na medida em que é difícil haver correspondência absoluta entre a realidade mencionada e os conhecimentos armazenados e estruturados em blocos, na memória do leitor - chamados modelos cognitivos. Na teoria dos frames ou esquemas, portanto, o conhecimento prévio configura-se como o aspecto mais importante no processo de compreensão, sendo que 
esses representam conhecimentos estereotípicos, comuns a uma dada cultura, em determinada época que sofrem variações conforme as vivências e crenças das pessoas.

Ainda na concepção da Inteligência Artificial, os frames fazem parte de uma rede de relações estabelecida entre os conhecimentos armazenados e evita uma sobrecarga de memória, viabilizando o processo de compreensão. No momento da leitura, os estímulos provocam a ativação dos conhecimentos, o leitor desencadeia o processo de ajustamento de frame, o que lhe possibilita compreender a informação proposta. Apesar de oferecer subsídios valiosos para o trabalho na área de leitura, a crítica da teoria aparece porque a princípio a aplicabilidade seria apenas para textos com informações conhecidas.

Ainda refletindo sobre o quadro da leitura sob outros ângulos de pesquisa, podemos citar a psicologia cognitiva e sua aplicação educacional que levanta considerações de leitura - o processo inferencial, os contextos linguísticos e nãolinguísticos, os conhecimentos partilhados entre autor e leitor. Uma abordagem cognitivista de leitura necessariamente deve incluir a noção de inferência.

Conforme foi mencionado anteriormente, o leitor, no momento da leitura, deixa aflorar o seu conhecimento de mundo, suas crenças, vivências, além de seu conhecimento linguístico e textual, isto é, todo o seu conhecimento prévio. Esses conhecimentos possibilitam a realização do processo inferencial que consiste no estabelecimento de conexões entre os enunciados, com o preenchimento de lacunas deixadas pelo texto, para chegar à construção do sentido. A realização de inferências é uma operação cognitiva bastante importante, que interfere no processo de compreensão e reforça a idéia de que o estabelecimento do sentido e da coerência textual depende da interação leitor-texto.

Com a efervescência destes estudos, surgiram pensadores e pesquisadores com a crença de que os estudos das frases em si como objeto não poderiam responder aos 
questionamentos contemporâneos da língua em uso ${ }^{3}$. Assume-se o texto, mas também já com a clareza de que ele é tributário de informações que vão para além dele próprio. Esta afirmação, porém, desconstruiria a idéia de que o conhecimento pode ser transmitido integralmente de uma pessoa para outra, pois a primeira interpretação destes estudos entendeu que cada um constrói seu próprio conhecimento. A compreensão seria o resultado de atividade mental do sujeito que se vale de conhecimentos armazenados em sua memória e outros conhecimentos que alcança externamente.

Assim podemos traçar um paralelo mostrando que de acordo com o paradigma preponderante em determinados períodos, os estudos de linguística pendiam para enfatizar o autor, a escrita ou o leitor, e apenas um destes, deixando os outros como coadjuvantes da cena maior, a leitura. O paralelo descrito abaixo seguirá três grandes correntes teóricas do século 20, com concepções de linguagem distintas quanto aos seus objetivos de uso $(\mathrm{KOCH}, 2000)$ para representar, como espelho do mundo e do pensamento; para comunicar, como ferramenta, instrumento (visão jakobsoniana de comunicação); e para interagir, como forma e lugar social.

A concepção da linguagem com a função de representação é o sistema que permite ao homem refletir o mundo para si e para o outro. Com a função de transmitir, a linguagem seria uma máquina de códigos acionada quando queremos nos comunicar. E, quando entendida como forma, a linguagem seria um lugar de ação social onde o humano interage com outros indivíduos.

${ }^{3}$ O linguista Marcos Bagno possui várias obras em que defende a gramática morta, a plasticidade da língua em uso. Em Preconceito Linguístico. O que é. Como se faz (São Paulo: Edições Loyola, 2002), o autor elenca oito mitos do preconceito linguístico, com atenção aos de número dois e seis, que dizem, respectivamente, que o brasileiro sabe falar português e fala o português do Brasil, diferente do de Portugal, por comodidade e razões históricas; e atenta ao ensino tendencioso e preconceituoso da língua ao julgar como "erradas" as pronúncias resultantes de forças internas que governam o idioma, já que as pronúncias, por motivos fisiológicos são diferentes em lugares e culturas diferentes, seja regional, quanto mais em outro país. 
Seguindo estas três concepções, a leitura também pode ser encarada a partir do estruturalismo, funcionalismo ou formalismo, presentes respectivamente nos paradigmas acima. A linguagem-representação vê o ato de ler como uma busca pelo leitor da arca do tesouro, escondida pelo autor. Ler é depreender o que o autor quis dizer, gerando uma clara aproximação aos ideais da filologia, segundo os quais um texto é a representação dos pensamentos de um autor imerso em seu momento histórico e social. Uma visão falaciosa, pois não é verdade a concepção de obra como um retrato da realidade. A realidade factual é impossível de ser retratada. Toda tentativa de reconstruí-la é um produto cultural. Podemos dizer que a realidade acontecida, nomeada como primeira realidade (KOSSOY, 1989), é reprocessada no indivíduo, e sua reorganização é uma outra instância de existência de uma outra realidade, que não a dos fatos ocorrentes, chamada de segunda realidade ou realidade simbólica. Dentro de nós, a primeira realidade é digerida, e, quando a devolvemos, deixa de ser realidade para se tornar uma produção simbólica, como discutiremos, no capítulo que trata da leitura a partir das teorias culturais. Neste ato de reprocessar, o homem filtra a primeira realidade com seus olhos enviesados por sua cultura, seu histórico de vida, ações, pensamentos e ideologias. Contamina a realidade com sua percepção de mundo contextualizada em um momento histórico, um estilo de vida, uma maneira social de pensar. Bakhtin (1993) com uma compreensão similar, estabelece uma separação entre dois mundos não comunicantes e mutuamente impenetráveis:

- o cosmo da vida, no qual conhecemos, contemplamos, vivemos e morremos, onde os atos e fatos acontecem uma única vez. É caótico e independe da interferência humana; 
- o cosmo da cultura, no qual os atos de nossa atividade são transsubjetivados e instrumentalizados. É uma tentativa de organização do anterior, e existe exclusivamente através do homem.

A teoria de que a linguagem é representação e que o autor é o detentor de sentidos do texto, apesar de sua importância ao fomentar inúmeros estudos de obras antigas, parte de um pressuposto irreal: de que o texto tenha um só sentido, que é aquele dado pelo autor e que, por meio de estratégias e metodologias de leitura, o leitor pode atingir esse sentido único. Estas estratégias seriam, de modo simplificado, buscar as palavras utilizadas no texto, sua relação com a época em que o autor o escreveu, incluindo aí dados biográficos e relações culturais de seu tempo. Os estudos atuais mostram que, partindo da polissemia das palavras, ao autor cabem escolhas semânticas provavelmente compatíveis com a gama de significados atualizados e potenciais que cada palavra carrega consigo, mas nada garante que, na leitura factual, quando o signo acontece (CRUZ, 1986regida predominantemente pela cultura vigente no leitor, o sentido, ou os sentidos, sejam fiéis à intencionalidade do autor. Estes estudos são de caráter exegético, geralmente conduzidos por eleição de interpretações tidas como “corretas", condenação de outras como "errôneas", ou "não autorizadas".

A concepção de linguagem como objeto de transmissão de mensagens opera numa perspectiva estruturalista e subjuga o texto como manifestação de uma estrutura, sem autoria, pois a linguagem seria uma espécie de ferramenta, instrumento que permite a transmissão de mensagens. Assim, cada texto significa o que significa, em função do próprio texto. Ao priorizar a estrutura textual, praticamente, corta-se a simbiose do texto com o autor, e de ambos com o leitor, defendida pelo autor Humberto Eco em sua Obra 
Aberta $^{4}$. Não se trata de negar a importância da corrente estruturalista nos estudos de literatura. Para o leitor hábil, que já possui bagagem e um histórico pessoal de leitura, é possível identificar os elementos quando o texto obedece a uma estrutura própria estrutura do conto, do romance, do ensaio, do conto de fadas etc. —, pois este leitor assimilou os elementos-padrão de um determinado tipo de texto. Esta é a concepção prevalecente hoje, em especial na escola, onde, muitas vezes, há uma leitura legitimada pelo professor, fundada na estrutura de base do texto. Essa concepção, por um lado, permitiu sistematizar, de alguma forma, os estudos sobre leitura e, por outro, abriu espaço para posições extremadas que viram o texto como objeto acabado. Mais que produto constituído de marcas negras em superfície branca, o texto é um conjunto de signos ávidos da figura humana, do leitor, para lhe atribuir sentido. Este sentido é o conteúdo próprio de um texto específico, que vai além do significado e da designação referente à realidade (verossimilhança) e relaciona-se às intenções, aos propósitos, às implicações etc. que cada texto apresenta. Deste modo, no ato da leitura, busca-se algo que está além da designação e do significado - busca-se o sentido. A mera decodificação não proporciona a leitura eficaz, principalmente tratando-se dos chamados textos literários, pois, como salienta Eugenio Coseriu:

O plano do sentido é, por assim dizer, duplamente semiótico, porque nele um significante e um significado de língua constituem uma primeira série de relações, seguida de outra série, em que o significado de língua passa, por sua vez, a ser "significante" para o conteúdo do texto ou sentido. [...] $O$ plano do sentido e do significado são sempre diferentes, mas, assim como o significado pode coincidir com a designação, o

\footnotetext{
${ }^{4} \mathrm{Na}$ introdução à segunda edição de seu livro Obra Aberta (São Paulo: Perspectiva, 1991), Umberto Eco faz três prognósticos sobre a leitura/literatura: $1^{\circ}$ - toda obra de arte é aberta porque não comporta apenas uma interpretação; $2^{\circ}$ - a "obra aberta" não é uma categoria crítica, mas um modelo teórico para tentar explicar a arte contemporânea; $3^{\circ}$ - qualquer referencial teórico usado para analisar a arte contemporânea não revela suas características estéticas, mas apenas um modo de ser dela segundo seus próprios pressupostos.
} 
sentido pode coincidir com o significado. Neste caso, o texto é tão somente comunicativo, informativo, empírico ou 'vital', e não artístico ou literário (1980, p. 99).

O que viria a ser o texto, se não é este objeto acabado? Esta especulação é importante na medida em que o exercício da leitura parte sempre de um texto. Para Herculano de Carvalho (1979), o texto é um produto da atividade mais imprescindível para a existência da vida humana em sociedade: a linguagem. Sendo a linguagem uma atividade com finalidades próprias, seja cognoscitiva ou interativa, ela é posta em prática pelo homem através do chamado ato de fala. Até aqui, temos ainda o texto em sentido amplo, incluindo a sua modalidade oral. Quando este texto falado é fixado graficamente, temos o texto escrito, em sua acepção mais comum. Nesta perspectiva, ler seria uma reconstituição intencional dos atos de fala.

A terceira concepção de linguagem centrada na ação humana abre espaço à vertente do leitor no processo da leitura. Diante de um texto, ele não só recebe informações, mas as produz, uma vez que, como sujeito ativo que é, sedimenta seu saber às informações recebidas. Melhor seria dizer saberes, que estão submetidos a condições como faixa etária, capacidade de abstração, desenvolvimento intelectual, experiência de mundo. Para Coseriu (1980), no exercício da linguagem, seja na produção ou recepção de textos, fazemos uso de três saberes: o saber elocucional, o chamado conhecimento de mundo; o saber idiomático, ou linguístico - acerca do idioma ou língua histórica utilizada; e o saber expressivo, também conhecido como o conhecimento sobre as modalidades textuais, em sua ampla concepção.

Essa concepção, focada no leitor, está muito presente no final do século 20 e com vigor no 21, denominado por alguns estudiosos como a Era do Leitor, uma vez que este ganha o status de co-produtor do texto lido. Enfatiza-se o termo "co-produtor", ao 
contrário do que fazem algumas autoridades, em tom demagógico, que se centram na leitura como discurso e declamam o leitor como "o produtor" do sentido.

Afirmar que o leitor tem total domínio sobre o sentido do texto é inverter o processo de quem domina quem, e, ainda assim, ter um olhar enviesado e incompleto sobre o objeto leitura. O leitor é um parceiro do autor, pois não mantém um comportamento passivo frente ao texto. Porém, não se pode negar que só aciona seus comandos mentais a partir daquilo que o autor lhe oferece. Sem dúvida, há um sentido que emana do texto. Ainda que por propostas conscientes do autor, por uma capacidade do autor em estabelecer uma relação cooperativa com seus leitores potenciais (leitor implícito na obra ${ }^{5}$ ), ou porque a língua na qual o texto está escrito carrega consigo uma história, construída individualmente, ou uma História coletiva e social. Isso nos remete a um dizer da Análise do Discurso, segundo qual o autor e o leitor são sujeitos relativamente livres, ou relativamente sujeitados à língua, pré-existente tanto ao autor quanto ao leitor. Ou seja, a leitura não pode ignorar fatores linguísticos, históricos, pessoais e pragmáticos, no momento da interação e de relações simbióticas presentes no ato da leitura. Ao adotarmos a leitura como processo interativo, descartamos a possibilidade de textos neutros, tanto do ponto de vista do autor, quanto do leitor. Assim o texto se coloca como um objeto cuja forma real vai sendo constituída no ato de leitura.

Convém assinalar, para esclarecimento do conceito da linguagem como interação, que estudos dos filósofos na década de 1960 do século passado abriram outras perspectivas para a linguagem-ação. No auge da metodologia da pesquisa-ação,

\footnotetext{
5 Diferente do termo "horizonte de expectativas" desenvolvido por Jauss Robert Hans, em Literatura medieval e teoria dos gêneros (1986). A respeito da teoria dos gêneros, o autor afirma que em toda obra está contido um leitor com informações prévias ou uma orientação da expectativa, um "horizonte de expectativa" que se constitui por uma tradição ou uma série de obras já conhecidas e pelo estado de espírito específico suscitado, com a aparição da obra nova, pelo seu gênero e suas regras do jogo. Hans nega a existência de uma obra literária que se localizasse numa espécie de vazio de informação e não dependesse de uma situação específica da compreensão. Nessa medida, toda obra literária pertence a um gênero, o que leva a afirmar que toda obra supõe o horizonte de uma expectativa, quer dizer, de um conjunto de regras preexistente para orientar a compreensão do leitor (do público) e lhe permitir uma recepção apreciativa.
} 
os sujeitos envolvidos na pesquisa eram instrumentalizados, viravam objetos em um laboratório (campo de pesquisa), controlados pelo pesquisador (detentor da verdade). Depois desta reflexão sobre esta práxis, a linguagem-ação passou a ser compreendida como forma, lugar onde se dá a prática de diferentes atos sociais, compromissados com o coletivo cujas regras são estabelecidas no próprio processo, e não ditadas pelo pesquisador. Assim, pela linguagem, a prática de atos sociais acarreta reações, comportamentos que fazem parte do jogo em que todos estão envolvidos. A interação não diz respeito apenas ao contato entre indivíduos, mas abrange a forma do contato, as reações dos parceiros sociais, uma vez que a linguagem passa a ser observada como atividade. Os sujeitos - aquele que estuda e o que é estudado - se relacionam mutuamente em situações pragmáticas.

Mencionamos que ao ler um texto o leitor coloca em ação saberes, os destacados por Coseriu (1980) e o horizonte de expectativa defendido por Jauss Hans (1986). Atualmente a expressão mais usada para designar os elementos acionados e articulados no ato de leitura é conhecimento prévio. Ângela Kleiman (2000) nos coloca que a leitura é um processo interativo, um intervir de vários fatores individuais, inconscientes e conscientes, que nos fazem compreender um texto escrito. Estes fatores podem estar armazenados na memória de longo prazo, portanto conhecimentos pré-históricos de origem; de médio prazo, contexto social contemporâneo; e de curto prazo, conhecimentos advindos de experiências únicas do repertório individual de cada ser. A autora reúne estes conhecimentos, inter-relacionados, em quatro tipos: o linguístico, o textual, o temático, e o enciclopédico.

Os conhecimentos linguísticos referem-se aos diferentes campos constitutivos da língua (lexical, fonológico, morfológico, sintático e semântico) e provém da experiência de fala, do uso da língua nativa. Assim, o domínio linguístico do leitor, com evidência para o vocabulário, seria determinante para a compreensão de conceitos e de sentidos. 
Entretanto é importante considerar que há diferentes graus de compreensão conceitual, que vão desde o total desconhecimento do sentido de várias expressões, a ponto de impedir a compreensão, até a possibilidade de atribuição de sentido no próprio texto, graças a associações que o leitor faz entre o termo utilizado e o contexto, ou entre o termo utilizado e seu conhecimento de mundo. Além do que, ao simplificar o sentido do texto à compreensão dos signos por raciocínio lógico, estaremos excluindo a noção de beleza de uma linguagem - métrica, rima, forma, cor, movimento - elementos sensibilizantes que tocam o inconsciente do leitor ${ }^{6} \cdot$. Onde se encaixa a sonoridade, tão vital em determinados textos? Santo Agostinho, em seu diário, se assim podemos dizer sobre Confessions (Cf. MANGUEL, 2005:97), conta que tinha o hábito - comum a muitos leitores - de ler qualquer coisa escrita que achasse, pelo puro prazer dos sons.

Quanto ao reconhecimento textual, este diz respeito aos modelos de textos fixados na memória, com suas estruturas, modo de organização das informações, tipos de discurso, e de seus usos; elementos que diferiam um poema de um despacho jurídico. Para Kleiman (2000), o conhecimento textual geralmente se apresenta de forma inconsciente para o leitor, pois é fruto de sua percepção em relação ao gênero do texto lido; similar ao horizonte de expectativa de Jauss Hans (1986). Nesta concepção, o leitor de alguma experiência, com seu estoque de esquemas, não esperaria uma construção de conto na notícia de jornal, ou, na notícia, um texto acadêmico. De fato, há um estranhamento, mas não uma incompatibilidade, como acontece com a inteligência artificial do leitor de disco rígido de um computador. Em saraus de leitura com livros da coleção "São Paulo de Perfill”, realizados em bibliotecas e escolas públicas, percebe-se que a proposta do escritor (seguindo ou não uma estrutura conhecida) é identificada na leitura das primeiras linhas do texto. O leitor busca, além da forma e estrutura, trocas de

\footnotetext{
${ }^{6}$ A docente Anna Maria Cintra, contou que, ao ler, a mando da professora, o épico Os Lusíadas de Luis de Camões, com 11 anos de idade, guarda a lembrança da experiência: encantamento pela sonoridade e frustração por não saber, afinal, sobre o que o autor estava falando.
} 
palavras que dialogam e criam uma rápida identificação, por proximidade, solidariedade ou repulsa.

El mismo acto que puede dar existencia a un texto, extraer sus revelaciones, multiplicar sus significados, reflejar en él el pasado, el presente y las posibilidades del futuro, puede también destruir o tratar de destruir la página viva. Todo lector inventa lecturas, que no es lo mismo que mentir; pero todo lector puede también mentir, subordinando caprichosamente un texto a una doctrina, a una ley arbitraria, a una ventaja personal, a la conveniencia de los dueños de esclavos o la autoridad de los tiranos. (MANGUEL, 2005:511)

O terceiro tipo de conhecimento seria o temático, que, como o textual, seguindo uma teoria prototípica, ativa o raciocínio por encaixe de elementos em rótulos e esquemas, porém vai além da bagagem acumulada de leituras, e diz respeito à experiência de mundo do leitor, podendo ser um conhecimento de ordem intuitiva e natural do indivíduo ou o formalizado e sistematizado. Esse tipo de conhecimento teria uma função econômica tanto para o autor quanto para o leitor, o primeiro para trabalho da linguagem e o segundo usando-o como "âncora" na construção de novos conhecimentos (KLEIMAN, 2000: 109).

Cada enfoque estuda a leitura por um ângulo - o texto, o autor e o leitor -, em função da visão sobre a função da linguagem; porém faltariam outros elementos, materiais ou abstratos, que variam conforme o momento em que a leitura acontece, denominados por Carvalho (1979, p. 232), como os contextos ou correlatos situacionais. Seria assim, contextos dependentes do quando, onde e como acontece a leitura, também chamados de condições (físicas) de leitura. Estes contextos consideram que o contorno, aquilo que está fora do texto em si, estão carregados de signos e significantes e influenciam indiretamente o ato de ler. Assim, a leitura permite que se 
crie um lugar e um tempo abstrato construído nesta relação simbiótica, entre texto, autor, leitor; e esta ambientação mescla-se com o tempo e os espaços reais do leitor. Lêse em poltronas ou no metrô, sentado, em pé ou deitado, com pouca ou muita luz, no silêncio, no barulho, na escola, dentro da sala de aula ou ao ar livre, no trabalho, em restaurantes, com letras miúdas ou grandes, serifadas ou sem serifas, em livros ou telas de computador. Os correlatos situacionais não apenas correspondem aos fatores físicos, mas capturam o momento do eu do leitor, seus assuntos mais recentes, seu estado emocional. Os fatores são infinitos, como cada momento único de leitura.

Na busca deste equilíbrio entre escrita, autor, leitor e contexto, a pesquisadora do Departamento de Ciências da Comunicação da Universidade de Lisboa, Maria Tereza Cruz (1986), faz uma revisão reflexiva sobre a estética da recepção ${ }^{7}$, sugerindo aos estudiosos de literatura uma revisão epistemológica que problematize o entendimento de obra centrada nas intenções do autor (poesis), deslocando seu "objeto" da crítica para um objeto-sujeito representado na figura do leitor (aisthesis). Vai além, ao propor não uma troca de papéis, mas um deslocamento que compreenda o processo sistêmico de encontro dos elementos atravessados durante o ato - texto, autor, leitor e contexto -, pois é desta simbiose que nasce o verdadeiro sentido da leitura, tecido fio a fio, individualmente.

A autora contextualiza a proposta da estética da recepção na necessidade de uma atualização das ciências humanas, de modo geral, inspirada pelas ciências duras, que têm superado o paradigma medieval na busca dos porquês, na ciência clássica no entendimento do como, e tem acrescentado, com na Física Moderna, com a teoria da relatividade, mais uma variável: para quem, o que, de certa, forma inclui os sujeitos no

\footnotetext{
7 Linha de pesquisa de problematização da supravalorização de uma verdade absoluta cartesiana substituta da experiência estética e intuitiva não-romantizada. Recentemente, a revalorização do domínio da experiência tem passado, por esta esteticização, ou seja, uma avaliação crítica das vivências de nós mesmos e do mundo. Neste sentido a Hermenêutica e a Pragmática modernas têm dado passos importantes para a sua recondução a uma articulação com as outras esferas da racionalidade moderna.
} 
diálogo científico, e que muitas vezes é falaciosamente interpretado como a humanização das Ciências. O problema não é inserir os sujeitos, mas sim, admitir que os sujeitos já estejam lá.

Se usarmos cada paradigma acima citado para entender a leitura, vemos que há uma coerência da linha histórica da epistemologia citada por Tereza Cruz (1986), e os paradigmas de estudo da leitura relatos, onde predominam o texto (linguagem como representação), o autor (linguagem como ferramenta), e o leitor (linguagem como interação). Os estudos de filologia, dessecantes dos signos, se dão quando o cientificismo está regido na procura dos porquês da leitura. Já a psicologia cognitiva busca a resposta no como é processada a leitura, de forma motora e biológica; enquanto que a pergunta para quem coloca o papel do leitor em destaque.

A ruptura proposta por Tereza Cruz não é a criação de uma novíssima teoria que elimina ou minimiza as correntes anteriores, e sim, em uma perspectiva kuhniana, assume que o conhecimento é construído de forma não-linear ou, nas palavras do autor norte-americano, quando a comunidade científica repudia um antigo paradigma, renuncia simultaneamente à maioria dos livros e artigos que o corporificam, deixando de considerá-los como objeto adequado ao escrutínio científico (KUHN, 2003:209). Nem por isso deixa de ser uma guinada de paradigma. A estética da recepção instalanos em um paradigma que Cruz chama interacionista e comunicativo, que não repete a linha de estudo do leitor ou do autor no centro do processo. Para entendermos o raciocínio da pesquisadora, há de se ressaltar que os conceitos-base de interação e de comunicação são conceitos atualizados pelos estudos de epistemologia, frutos de estudos contemporâneos, principalmente sobre Teoria da Comunicação. Mencionou-se, em outra oportunidade, a noção de interação, que depois da década de 1960 foi ajustada, colocando o objeto-sujeito como parte integrante, participativa e transformadora da pesquisa e do pesquisador. 
Antes, seguindo o modelo jakobsoniano e saussuriano, a comunicação era vista como um fenômeno similar a uma corrente elétrica. Estudava-se comunicação dividindo-se o processo iniciado em um emissor, detentor de significados traduzido em uma mensagem organizada em códigos, que transmite sua intencionalidade utilizando um meio ou canal (papel, computador, televisão, rádio, jornal) a um receptor, que pode ser ou não o destinatário, que decifrará os signos da mensagem na procura do significado proposto pelo emissor. Quando o receptor não corresponde à intencionalidade do emissor, há o que se chamou de ruído, uma interrupção do processo que impede a passagem vetorial de sentido único do pólo emissor para o pólo receptor.

Cremilda Medina, em seu estudo e prática de comunicação social - com a palavra e o conceito de social co-existente ao processo de comunicação -, questiona o modelo partitivo que funciona como uma transmissão vetorial, estruturado na idéia difusionista, na qual uma mensagem oficial determinada e decidida por instâncias autorizadas deve ser processada por intermediários presentes em meios de comunicação, e chegar aos receptores com os dados e significados pré-escolhidos. Esta transmissão é ditatorial, na medida em que não ouve à oferta de informações em demandas coletivas, anônimas, ou grupais, descentralizadas dos grandes pólos de geração. Nos processos comunicativos, percebe-se, entre outros fatores, o papel do mediador de agentes culturais que se consagraram, nas sociedades democráticas, como comunicadores. Este paradigma, o Signo da Relação, vê a comunicação como um fluxo de trocas e de relações intrínsecas ${ }^{8}$.

Portanto o processo de comunicação aplicado à leitura aconteceria como um fluxo de trocas em todos os elementos componentes do processo. Assim, não se trata de decodificar o sentido do texto - um ato condicionado e autômato, de recepção. Trata-se de acionar o raciocínio para construção de conhecimento - incondicionado, espontâneo

\footnotetext{
${ }^{8}$ O Signo da Relação na comunicação será abordado de forma diluída em capítulos conseguintes e, especificamente, no capítulo 8.
} 
e autônomo - a partir de uma obra, e daí entrar em um cosmos de signos, significantes e significados provenientes tanto do leitor, o qual a autora denomina "leitor implicado", quanto do escritor, da materialidade do texto, do ambiente no qual o signo acontece, e outros tantos elementos que se inter-relacionam criativamente em prol da construção dos sentidos comprometidos com o espaço e o tempo circunstancial do ato. Citando Tereza Cruz:

A recepção é um processo complexo no qual a obra é recriada, tornando-se assim um produto da sua interação com o leitor. (CRUZ, 1986)

Em uma compreensão ampliada, a pesquisadora portuguesa vislumbra o signo em movimento, no qual as partes estáticas de sua composição, o significado e o significante, são pontos de partida ao invés de conclusivos, e seu sentido é extraído durante o acontecimento do signo. Para o autor espanhol Manguel, o leitor extrai seu significado mediante um método muito complicado de significados apreendidos de convenções sociais, leituras anteriores, experiências pessoais e gostos individuais (2005:98), por um processo que confere ao texto algo - emoções, sensações físicas, intuição, conhecimento, alma - que depende de quem sou e de como cheguei a ser o que sou.

A estética da recepção sobre estudos de leitura, alimentados pela comunicação de trocas mútuas, vê que a cerne da leitura não pode passar por um deslocamento de atores e coadjuvantes, entre autor, obra e leitor, mas sim no encontro de todos estes e outros elementos, na síntese resultante (diálogo) dos sentidos atravessados.

Talvez se possa dizer que a compreensão resulta de uma atividade do leitor, em busca da construção de sentido e que, nesse processo, a decifração dos códigos é apenas 
uma etapa que leva à compreensão e não é um fim em si mesmo. Isso não quer dizer que o leitor implicado é o detentor único do texto, seria negar o princípio de autoria.

Poderíamos dizer que o significado do signo acontece num campo de forças movidas pela singularidade dos seres humanos, autores e leitores, sintonizados com o seu presente histórico. Assim, o signo acontece quando surge uma combinação do significado pretendido pelo autor, que possui uma linguagem marcada pelo momento histórico da escrita (ainda que seja uma obra de recriação de outro momento histórico), e o significado apreendido pelo leitor, também comprometido com seu tempo. Cada um lê com os olhos que tem, e interpreta a partir de onde os pés pisam, diz Leonardo Boff (1997)

Ou, se considerarmos a historicidade da leitura, a dimensão do leitor pode ser observada na intersecção de dois fatores que atuam no momento da leitura: a história de leitura dos textos e a história de leitura do leitor ${ }^{9}$, como propõe Orlandi (1996) perfazendo um gráfico que poderia ser assim materializado:

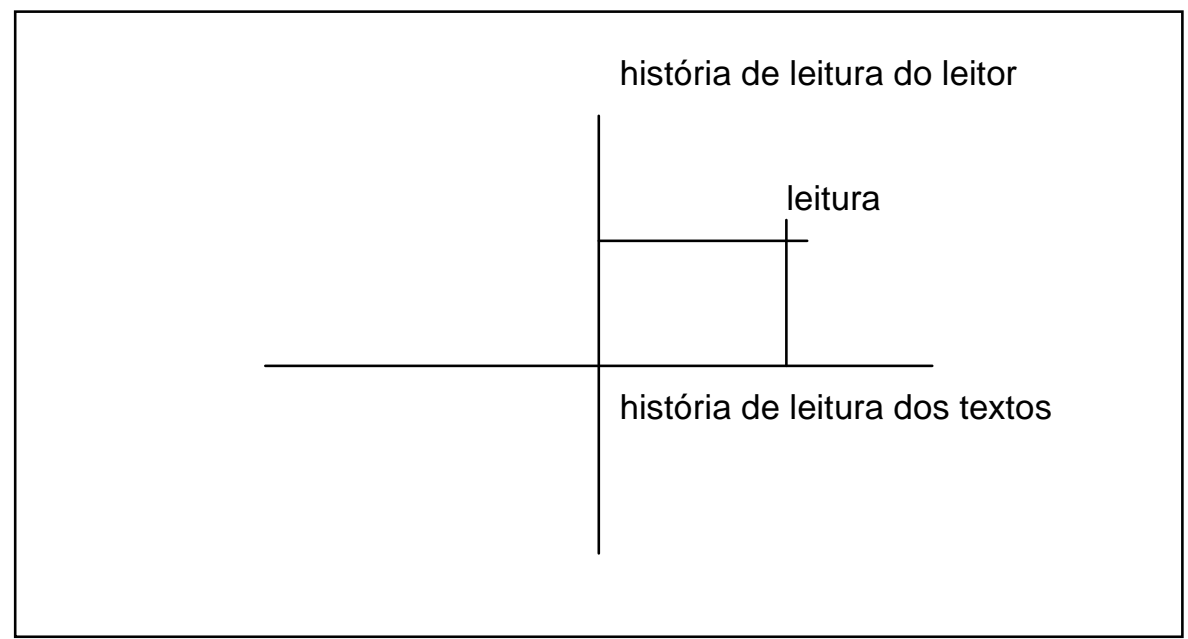

\footnotetext{
${ }^{9}$ Para Orlandi (1996: 87), a história de leitura do leitor e a história de leitura dos textos constituem o aspecto previsível da leitura, cabendo à história o aspecto imprevisível, pois o contexto histórico-social em que a leitura é realizada gera a pluralidade possível e desejável da leitura.
} 
Com essas pinceladas podemos vislumbrar um quadro sobre a leitura em que ao leitor é atribuída grande parte da responsabilidade pelo estabelecimento da coerência textual, o texto seria o guia na busca do sentido, pois, na verdade, o processo de compreensão vai suscitar a construção de um novo texto pelo leitor. O sentido do texto é construído, portanto, a cada leitura que se realiza. Nessa direção, situa-se Arrojo (1985), ao questionar a estabilidade do texto original e a própria autoridade do autor. Diz ela que o autor "pode visitar o seu texto como convidado e não como pai absoluto que possa controlar os destinos de sua prole".

Considerando a leitura como atividade produtora, através da qual o texto se realiza e atualiza, a autora atribui ao texto a imagem de um palimpsesto: "O texto que se apaga em cada comunidade cultural e em cada época para dar lugar a outra escritura do mesmo texto". Por isso, ao leitor é dada a oportunidade de reescrever os textos, verbalizando-os a partir dos estímulos textuais, mas com base em sua própria bagagem cognitiva.

As reflexões apontam para a questão da abertura do texto. Deve-se, no entanto, ressaltar que não se está propondo a idéia de uma abertura total, da liberdade absoluta de interpretação. Não se pode ignorar que há pistas no texto que possibilitam a recuperação da essência do seu conteúdo. São elucidativas as palavras de Fiorin (1989, p. 81) a esse respeito, ao afirmar que "as diversas leituras que o texto aceita já estão nele inscritas como possibilidades, (...) e não se fazem a partir do arbítrio do leitor, mas das virtualidades significativas presentes no texto". Portanto, a ocorrência de inferências faz parte do processo de compreensão e, sem dúvida, deve ser levada em conta, porém dentro de limites aceitáveis, com a realização de leituras(s) autorizadas(s) pelo próprio texto. 


\section{Capítulo 5}

\section{Escala Prosódica}

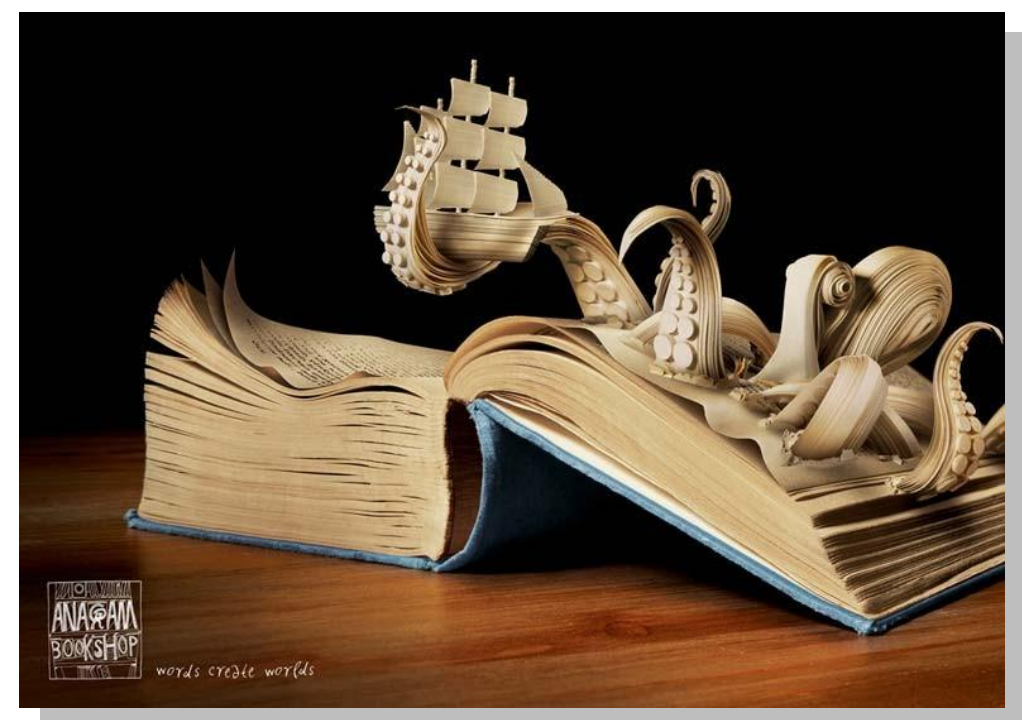

ESCOLA DE COMUNICAÇÕES E ARTES Doutorado em Ciências da Comunicação Teoria e Pesquisa em Comunicação 


\section{Capítulo 5}

\section{Leitura}

\section{Escala Prosódica}

É comum a concepção escolar de que constitui um elemento facilitador ensinar a ler neutralizando a leitura vocalizada em voz alta. No ensino tradicional de alfabetização ocidental acredita-se primeiro ser necessária uma leitura artificializada, fragmentada, de decodificação para, só depois de um estágio mais avançado, introduzir a leitura prosódica. No entanto, as dificuldades de interpretação de textos apresentadas em pesquisas de analfabetismo funcional provocaram neste trabalho uma reflexão a respeito da necessidade, já nos estágios iniciais da aquisição da lectoescritura, do estímulo e complementação da leitura com a prosódica, que segundo alguns estudos recentes, auxiliam na maior compreensão do texto do que a leitura artificializada, proposta pela escola.

É comum a rápida associação da palavra como uma das ferramentas mais significativas da magnífica capacidade humana para o raciocínio lógico. Assim como a leitura é facilmente entendida como uma atividade mental extremamente complexa e requer o uso de diferentes processos cognitivos, que vão desde o reconhecimento de palavras e o acesso ao seu significado, passando pela divisão sintática, pela análise semântica e pela interpretação de todo o texto lido. Apesar de poder ser definida e investigada sob vários ângulos, relacionando-se a diversas perspectivas teóricometodológicas, escolhi a concepção de Larrosa (2001), quando diz que a palavra é mais que instrumento, é o próprio ser humano, porque somos simplesmente organismos vivos, mas é a palavra que produz em nós os sentidos. A construção dos significados que nos movem se dá a partir de uma relação visceral entre o ser humano e a linguagem, transformando o que acontece (primeira realidade) em algo que nos acontece (realidade 
simbólica). Nessa relação visceral parece que quando experimentamos a realidade factual (o acontecido) em palavras, as próprias palavras também nos experimentam.

Quando fazemos coisas com as palavras, do que se trata é de como damos sentido ao que somos e ao que nos acontece, de como correlacionamos as palavras e as coisas, de como nomeamos o que vemos ou o que sentimos, e de como vemos e sentimos o que nomeamos. (LARROSA, 2001: 1)

Vistas sob esse parâmetro, as experimentações da linguagem que fazemos seja pela escrita ou pela leitura não cabe circunscrita em um olhar exclusivamente estacionário, mecanicista, muito menos sistêmico da língua. Ao contrário, aponta em direção a uma concepção dinâmica, interativa, em que as palavras, ao se transitarem entre os seres humanos e pela humanidade, estão constantemente se enchendo e esvaziando-se de significação. Ao dar à linguagem uma natureza de movimento, de constante transmutação, vislumbraremos a linguagem como sugere Bakhtin (1995), pensar a locução e a compreensão de forma ativa.

Unida às experiências e observações dos saraus de leitura sempre elucidados pela pesquisa deste trabalho, a compreensão da linguagem enquanto significantes e significados com dinamicidade parecem, por observação da pesquisa, que ao ouvirmos uma leitura, de outrem ou de nós mesmo, somos impulsionados a enunciar algo mais, seja em palavras, gestos, sons, pinturas, etc. Os significados sinergicamente se multiplicam.

Ocorre que para experimentarmos a linguagem e sermos experimentadas por ela, é preciso combater, antes do analfabetismo dito funcional, aquele da decodificação de palavras, outro tipo de analfabetismo nomeado por Luiz Carlos Restrepo (1998) como analfabetismo afetivo. É um analfabetismo relacionado com a sensibilização, a 
capacidade de comoção, de restabelecermos ou simplesmente percebermos (uma vez que a conexão está sempre lá, é preciso desprendimento para senti-la) a teia invisível que nos une. Para isso é preciso restabelecer a comunhão entre os seres e o mundo, essa sim a verdadeira e eficaz comunicação.

Para Restrepo, a percepção dessa teia que é traçada no cotidiano, na vivência, no contato, e necessita vencer barreiras impostas pela atrofia dos nossos sentidos e pela imposição do divórcio positivista entre a razão e a emoção. Em O Direito à Ternura, ao criticar a atrofia ou parcialidade dos sentidos, Restrepo resgata uma palavra interessante: splacnisomai. Segundo o autor, a palavra desaparecida entre os séculos II e III da era atual, corresponderia hoje numa tradução literal, algo como "sentir com as tripas". Restrepo ressalta que o que caracteriza o humano e o distancia da inteligência artificial é justamente a capacidade de se emocionar; reconstruir o mundo e o conhecimento a partir dos laços afetivos que nos une; somente através da conjugação ativa do verbo splacnisomai é possível desentupir ouvidos, poros, narinas, olhares e sabores e estar realmente atento e afeto à experiência e experimentação do mundo, do Outro, e sermos assim, por estes experimentados. Para Medina (2006), se não combatermos o analfabetismo afetivo na cultura ocidental, aquele que atrofia os sentidos humanos, especialmente aqueles que favorecem a aproximação corporal da relação humana - tato, olfato e paladar - incentivaremos o desenvolvimento de esquizofrênicos sociais: ouvindo o que nos convém e olhando apenas o que nos interessa. É preciso estar disposto e afeto ao que nos rodeia para que o escutado, lido, tocado, visto possa ser compreendido para então tornar-se novamente enunciação, uma enunciação que é experiência.

A experiência, a possibilidade de que algo nos aconteça ou nos toque, requer um gesto de interrupção, um gesto que é quase impossível nos tempos que correm: requer 
parar para pensar, parar para olhar, parar para escutar, pensar mais devagar, olhar mais devagar, e escutar mais devagar; parar para sentir, sentir mais divagar, demorarse nos detalhes, suspender a opinião, suspender o juizo, suspender a vontade, suspender o automatismo da ação, cultivar a atenção e a delicadeza, abrir os olhos e os ouvidos, falar sobre o que nos acontece, aprender a lentidão, escutar aos outros, cultivar a arte do encontro, calar muito, dar-se tempo e espaço (LARROSA, 2001, 4)

Para que relação do ser humano com as palavras e com o mundo não se esvazie na lógica da informação, do automatismo, é preciso nos permitir a nós mesmos o contato visceral com a linguagem, com a realidade e os significados que nos rodeiam, de forma que nessas interações haja aberturas para enfrentarmos conflitos, compreensões, metamorfoses.

Comparativamente, a experimentação das palavras e a vivência dos textos parece se fortalecer quando os significados são multiplicados em todos os sentidos e sensibilidade, quando se completam em estímulos além dos visuais, da decodificação das letras. As vozes, os sons, os gestos, a respiração, a pausa produzidos pelos leitores da leitura dramatizada (ou prosódica) geralmente ressoam nos ouvidos, vibram no corpo.

Embora existam autores que estabeleçam uma distinção entre prosódia e entonação, tomaremos a noção de prosódia como o estudo das propriedades acústicas da fala, geralmente não preditas pela transcrição ortográfica, como por exemplo, ritmo, entonação e demais atributos correlatos na fala. Quando for citado o termo prosódia, estamos abrangendo tanto os sistemas cognitivos abstratos quanto aos parâmetros físicos nos quais estes sistemas abstratos são mapeados, ou seja, a prosódia lexical (tom, acento e quantidade) e a prosódia não-lexical (entonação). 
A prosódia assume um papel de destaque no ato de ler quando a compreendemos como co-responsável pela estruturação sintática do discurso, uma vez que há possibilidades de padrões entonativos e estes causam mudança de significado. A relação sintaxe-entonação-significado é importante para as reflexões deste capítulo, pois deixa clara a importância da entonação para o acesso ao significado nascidos da leitura. Admitiremos, assim, a concepção de prosódica inspirado em autores como Ladd (1996) que prioriza a importância do uso de características fonéticas para atribuir significados pragmáticos pós-lexicais, e Reis (2001) sobre o fato de a entonação participar de forma fundamental na interpretação semântica de um enunciado.

De acordo com as observações e reflexões dos saraus, a prosódia na leitura em voz alta, com suas variações e conjuntos, parece projetar, paradoxalmente, um espectro materializado do texto, tornando a leitura mais efetiva quanto à convocação, ao encantamento das palavras, ao toque no outro. Quando dramatizadas, as palavras, antes descansando no papel, através da composição de vozes e sons, alargam-se no espaço, libertam-se da retina e viajam ouvidos adentro. $\mathrm{O}$ movimento sonoro conferido às palavras as tira da fixidez do papel, as transforma em material de experimentação, tocando-nos uns aos outros no ato da audição. Zumthor (1997), assim como Restrepo fala do sentido auditivo, nos dá a dimensão da importância da voz como um dos fios invisíveis da teia que nos entrelaça:

A enunciação da palavra ganha em si mesma valor de ato simbólico: graças à voz ela é exibição e dom, agressão, conquista e esperança de consumação do outro; (...) o som vocalizado vai de interior a interior e liga, sem outra mediação, duas existências (ZUMTHOR, 1997, p.15) 
Embora a leitura silenciosa fosse uma opção de "modalidade", e foi a escolha em alguns saraus, percebi que essa somente fluía naturalmente, sem intervenção de um mediador, quando o público já obtinha histórico de habilidade e familiaridade com a leitura. Unanimidade mesmo - inclusive com públicos de certa dificuldade de decodificação da linguagem verbalizada em texto escrito, seja por falta de contato usual com a leitura ou até mesmo em processo de alfabetização -, aconteceu com a leitura dramatizada, inspirada na prática do isaurau como afetivamente descrevemos anteriormente. Ao colocar em suas vozes os textos, os participantes dos saraus, muitas vezes alteravam-nos, ria-se de si mesmo, assumiam explicitamente o papel de coautores, enredavam nos versos suas experiências de leitura e quiçá suas vivências particulares. Trabalhando a prosódia no texto durante a leitura, os participantes leitores dos saraus optavam, enfim, não pela leitura parafrásica de reprodução do texto, mas por "senti-los nas tripas", impregnando-se das palavras e de suas compreensões, reverberando suas vozes que entram texto adentro e parecem se tornar acontecimento, enunciação. É como se, ao lermos um texto, o transformássemos concretamente em outro; um outro que nasceu do primeiro, mas que, ao ser lido oralmente, assume outra voz concretamente e metaforicamente. É uma relação visceral dupla: a letra após se transformar em estímulos visuais torna-se som e entra novamente no leitor, desta vez pelos ouvidos. Ao serem colocados lado a lado, desenho e som, letra e voz, um potencializa o outro, tirando o leitor da inércia de ouvir parado. Como se o movimento do som arrancasse o corpo da imobilidade. Ao ler o texto em voz alta, os leitoresouvintes transformavam-no com certa naturalidade. Ou era o texto que os transformavam?

Convido a um exercício de imaginação. Tentemos reconstruir o momento primórdio quando homens e mulheres, crianças e velhos reunidos ao redor do fogo, aqueciam-se pelo calor da fogueira, pela voz e presença humanas nos contos de roda, 
por vezes míticos. Ou ainda as cantigas de ninar, os contos e causos passados de geração em geração, ao calor do corpo e do leite maternos. É no território mágico e singelo da narração que o afeto tem livre circulação e a voz humana ocupa uma dimensão de intimidade, pois cria presença e trás consigo a consciência de presença. $\mathrm{O}$ território da voz humana cria uma subjetividade que ao mesmo tempo se interioriza no afeto e se exterioriza no compartilhamento.

Pela leitura dramatizada realizada nos isaurau, vê-se a importância da alfabetização afetiva proposta por Restrepo (1998) onde o ser humano impregna-se do mundo por todos os sentidos, tanto os que são estimulados à distância - audição, visão e olfato - quanto os que requerem o contato - paladar e tato. No entanto, para a abertura incensurável dos sentidos é preciso uma pré-disposição para deixar-se impregnar. Neste sentido, a afetividade do leitor transparecida na leitura dramatizada parece estabelecer um contato mais intimizado com o texto, criando uma empatia do texto com o grupo, e nas pessoas do grupo.

Uma rápida análise sobre a importância da voz na leitura poderia nos levar à solução da leitura dos chamados audiobooks, ou, áudio livros. Porém, os atributos da leitura dramatizada vão além da dimensão da voz. Os elementos proxêmicos fazem o texto transpassar o corpo que ressoa a leitura e desperta olhares e gestos dos leitores. A palavra, ao ser enunciada, parece se transformar em um ser concreto; faz-se no corpo. Uma vez personificada, torna plausível sentir as palavras “com as tripas”, vivenciá-la, criando um clima de empatia entre leitores e palavras. Essa empatia pode surgir do que Zumthor chama de oralidade, vinda do ato de busca e de conhecimento do Outro:

A oralidade não se reduz à ação da voz. [...] A oralidade implica tudo o que, em nós, se endereça ao outro seja um gesto mudo, um olhar. (ZUMTHOR, 1997, 203) 
Nesse aspecto, lido em voz alta em conjunto, o texto torna-se autenticamente coletivo, e a leitura, verdadeiramente colaborativa. Uma pronúncia incorreta, um deslize no encontro da linha conseguinte, uma falta de fôlego, é espontaneamente ancorado pela solidariedade do grupo. A construção dos significados do texto, os sentidos aflorados, até mesmo a prosódia é de autoria coletiva. Aspectos da leitura dramatizada que merecem uma reflexão mais aprofundada, como poderemos realizar posteriormente.

Ainda em busca da compreensão da instantânea empatia causada pela leitura dramatizada - o que muitas vezes não acontecia na leitura silenciosa - observa-se que o trabalho com os gestos, com o olhar, a interação com o público, os significados provindos da proxêmica são fundamentais, exigem do leitor o mergulho no texto não apenas com os olhos, mas com os lábios, com o manuseio virtual, com o cheiro.

Seria uma "repaginação" do que acontecia na Idade Média, quando uma obra seria impensável sem a voz, sem o corpo ou sem o público? Para Santo Agostinho, e, posteriormente, por toda a Idade Média, a leitura era uma atividade oral, articulada, que implicava uma participação da voz como condensação de todo o corpo. A leitura oralizada permitia a análise do corpo do texto que, por ser essencialmente, oralizado, não se dispunha ainda através dos procedimentos gráficos. A imprensa vem, sobre esse aspecto, clarificar o texto, torná-lo legível aos olhos, dispô-lo segundo uma lógica não mais auditiva, mas, sobretudo visual. Nos estudos da prática de leitura e obras medievais, Zumthor utiliza o conceito de performance para explicitar a presença do corpo na literatura oral. Para o autor, como na declamação de poemas, poesias, tratados e condenações em praça pública, o leitor, o público é ativo, faz parte da obra: o “ouvinte-espectador é, de algum modo, co-autor da obra” (ZUMTHOR, 1993, 222). E é da interação poeta-público que emerge a performance: 
O intérprete, na performance, exibindo seu corpo e seu cenário, não está apelando somente à visualidade. Ele se oferece a um contato. Eu o ouço, vejo-o, virtualmente eu o toco. (ZUMTHOR, 1997, 204).

Ao emprestar a definição de performance à leitura dramatizada, da-se foco para alguns aspectos que podem ser significativos na acontecência da leitura dramatizada: cada performance é epifânica, uma energia surgida no "atrito" da relação interativa entre os participantes dos saraus de leitura. A leitura dramatizada é simultaneamente corpo, voz, canção e criação.

Mesmo quando os participantes dos saraus desenvolvem um roteiro de apresentação [como aconteceu em 17 de agosto de 2006 na turma de $8^{\circ}$ série da Escola Adventista do Jardim das Palmeiras localizada na região Sul de São Paulo, e também no dia 22 de março de 2005 na Biblioteca Alceu Amoroso Lima com o público da biblioteca apresentado por um grupo de graduandos da Escola de Comunicações e Artes da Universidade de São Paulo], ao incorporarem as palavras, ainda que fossem intencionadas e ensaiadas as características prosódicas da performance, a cada apresentação surgia da repetição uma novidade. É como se o texto escrito provocasse, através da imprevisibilidade da primeira realidade, a factual - a interpretação do tom, do ritmo, dos gestos -, significações singulares, irreprodutíveis e intransferíveis. Uma singularidade dada justamente pelo seu caráter enunciativo, prosódico, e acima de tudo, factual. A acontecência da leitura, diante da imprevisibilidade do acontecimento, confere ao texto influência de diversos fatores (entre eles, podemos citar os contextuais, rítmicos, informacionais, sintáticos, semânticos e pragmáticos), a fim de produzir um enunciado coerente e que transmita as emoções e atitudes do falante. A leitura e a produção de texto, a partir deste ponto de vista, sempre é acontecimento; e um acontecimento do qual não se pode excluir o gesto, o som, a imagem. 
Interessante atentar que dentre as linguagens, mesmo com a expansão dos recurso audiovisuais, o mundo das palavras é soberano na história ocidental. $\mathrm{Na}$ educação, na sala de aula, na academia, o recurso verbal predomina como forma de veicular o conhecimento. Mas se vivemos numa sociedade onde a palavra e a informação ocupa um espaço de supervalorização, porque tantas dificuldades em relação à interpretação e habilidades de leitura? Talvez seja justamente porque as leituras e a relação com a palavra estejam separadas do corpo que a faz existência. Não seria o nosso parentesco carnal com o mundo que nos faz percebê-lo? E para tornar-se carne, a palavra não pode estar restrita a sensibilização por um ou dois sentidos, de acordo com Restrepo, a visão e a audição, e mesmo assim com cerceamentos autocensuráveis. A palavra lida com o corpo transcende a si mesma enquanto linguagem, e, geralmente, provoca movimento. Não se pode destituí-la do corpo, mas talvez seja nele e através dele que elaboramos as possibilidades de significações.

A leitura dramatizada seria então um caminho para alcançar o anseio da leitura e da linguagem em ação que transforma o ser? A questão é que não podemos ignorar a implicação da participação do corpo na leitura.

Porque entender a escrita e a sua complementar operação, a leitura, como oralizantes seria ligá-las indissoluvelmente à presença dos sujeitos, fazer do corpo o ponto de ancoragem, a materialização das ausências, se não material, de forma virtualizada na imaginação do leitor? Não substituindo a escrita de imaterialidade dos sujeitos envolvidos, autores e leitores, mas como passagem para a escrita e leitura como é concebida hoje, pela ausência do evento. Em primeira instância, o leitor ocidental receberia a escrita por seu caráter fonológico, ao lado da fala como acontecimento, para depois passar para o uso da linguagem como processos abstratizantes que articulam a leitura como uma operação desmaterializada. 
Segundo a autora Maria Augusta Babo (1996), são três os séculos em que leitura vem perdendo seu pilar na materialidade da voz para se imaterializar na decodificação da grafia. Para ela, a leitura é atualmente um fenômeno acentuadamente visual e não vocal. E nesse raciocínio, seus estudos vêm ao encontro da reflexão dos saraus, uma vez que mostram a habilidade de leitura diretamente ligada à capacidade do sujeito leitor em operar uma total distinção entre a leitura articulada, dramatizada ou imaginada e a leitura puramente visual.

Ainda de acordo com a autora, além da vocalização da leitura, alia-se outra característica de legibilidade, a coletiva. A leitura como ação e atitude individualizada é uma experiência relativamente recente. $\mathrm{O}$ ato de ler carrega consigo uma tradição cultural de ação coletiva, de interatividade, uma atitude cultural de grupo que alia a escrita a esta recriação epifânica, como numa interpretação musical de uma partitura. Descreve a autora que o leitor posicionava-se na leitura enquanto um ator, um intérprete que através da interiorização do texto, encarnava o Outro, presentificando através do seu próprio corpo a ausência do corpo-outro. Compartilhada, a leitura ganhava uma dimensão coletiva de apreensão do sentido, talvez hoje um pouco ou totalmente desabitual, mas não esquecida, visto que em algum lugar da memória coletiva, guardase esse know how da humanidade. Para Babo (1996), a leitura na contemporaneidade saiu do espaço exterior e público, ato de compreensão coletiva. A leitura interiorizou-se, tornando-se um ato privado, com a emergência e imposição do individualismo e o culto da subjetividade. Mas se o caminho está traçado, nada impede que os percorramos em ambos os sentidos, sem caracterizar retrocesso.

Atendo-se ao sentido da visão, quantas vezes no processo de alfabetização a leitura exigida restringe-se à visual, tornando um jogo de captação, adivinhação, decifração, uma atitude de antecipação. Talvez um jogo até necessário, mas precisaria ir além, por exemplo, quando a leitura de textos ditos difíceis, mais elaborados e abstratos, 
exige do leitor uma atitude participativa, requer uma constante construção e desconstrução de hipóteses a partir das quais se tenta interpretar o que se lê. Essa perceptível descentralização do corpo da phonè para o grafein acarretaria, do ponto de vista das teorias do texto e da leitura, outra possibilidade de entendimento do texto escrito que o aproxima de uma origem comum com o desenho. (Re)aproximando a escrita do desenho, talvez há de se re-equacionar os modos de ler, uma vez que a legibilidade seria uma operação em que o ver não esgota o mecanismo de leitura. Neste sentido, a leitura só seria possível, paradoxalmente, quando a letra perde sua visibilidade. O lugar ambíguo da letra dá lugar ao Outro.

Unida ao estímulo visual, a escuta seria, entre outras possibilidades, uma modalidade de leitura. A entonação/audição permite um preenchimento e avaliação do espaço, um poderoso meio para a delimitação da situação espaço-temporal. É o som que nos permite circunscrever um território, através da determinação de fronteiras entre o espaço e o tempo. O sentido auditivo estaria ligada à um aspecto hermenêutico, determinando, analisando, avaliando o dito para atingir o não-dito, buscando o que se esconde no subentendido.

A literacia, como é chamada por alguns autores para distinguir a prática e a competência da leitura de procedimentos puramente técnicos de decifração, implica, como apregoou Restrepo (1998), numa atitude, um modo de estar em sociedade, porque ela é, acima de tudo, uma via para a compreensão do mundo, da ordem das coisas, do ser. Para alcançar a literacia, um caminho proposto por esse trabalho seria o leitura “sentida pelas tripas", feita com o corpo, com a integridade do ser. 


\section{Capítulo 6}

\section{Escala escolar}
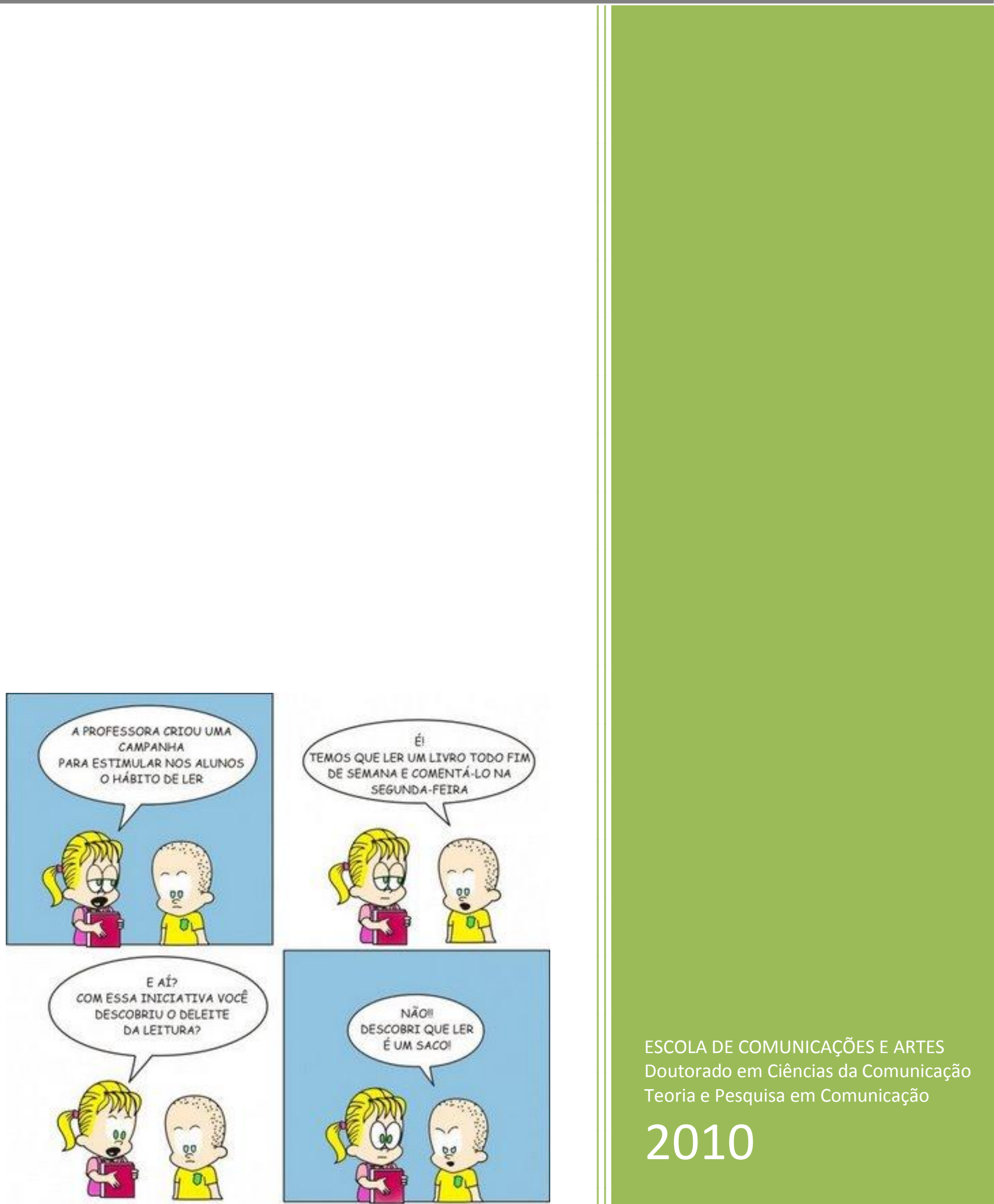

http://creisigirl.wordpress.com/

ESCOLA DE COMUNICAÇÕES E ARTES Doutorado em Ciências da Comunicação Teoria e Pesquisa em Comunicação

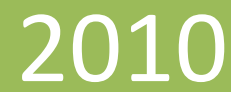




\section{Capitulo 6}

\section{Leitura}

\section{Escala escolar}

Nesta paragem refletirem sobre ler e escrever como atos de cidadania com grande influência da instituição escolar, portanto importante mediação participativa dos professores. Estes lamentam um quadro em que seus alunos apresentam-se com dificuldades tanto de escrever com clareza quanto de interpretar adequadamente um texto. Porque embora se fale na era da informação, de forma paradoxal, calcula-se um grande contingente de analfabetos funcionais com dificuldades de comunicação.

Ao se falar em leitura nas escolas, a primeira associação é com o ensino de português e de literatura. De fato, a leitura institucionalizada na escola ficou, historicamente, presa, em um primeiro momento, ao dito letramento, reduzida em atividades para o desenvolvimento das habilidades de decodificação e de compreensão e interpretação de textos didáticos. Habilidades trabalhadas, em sua maioria, em situações artificiais de comunicação, simuladas em livros didáticos, limitadas ao plano da funcionalidade. Mais tarde, ganhou importância junto à criação da disciplina de Literatura.

Nem na disciplina de Português, muito menos em Literatura, estas técnicas têm sido uma boa estratégia para a fermentação de leitores. Fermentação, em substituição de formação, porque, a meu ver, esta é a imagem mais próxima do que ocorra para quanto se conquista um leitor. O que proporciona o surgimento de um leitor é o estímulo, o fermento, e não a fôrma. 
Percorrendo algumas das várias propostas pedagógicas, constata-se que é intrínseca à concepção de educação escolar a idéia de formação: a instituição escolar e o professor possuem a tarefa de formar o indivíduo como se ele fosse desprovido de qualquer outra forma anterior. E mais, esta formação é atrelada sempre à mente. Tem-se que o corpo desenvolve-se autonomamente, independente de uma vontade ou de uma consciência, enquanto que a mente é desenvolvida à custa de uma intencionalidade, geralmente prevalecendo a do educador, que abafa a do próprio educando. A questão ainda está por se resolver: até que ponto há uma total autonomia do corpo sobre si mesmo, e se a mente e o corpo são indissociáveis (DAMÁSIO, 1996), qual é o limite de controle e manipulação da mente. Cérebro e corpo se imbricam, não havendo controle de um sobre o outro, como afirma António Damásio. Mas, o corpo pensa? Não é a mente que pensa? O corpo é visto como o lugar em que são desencadeados os processos cognitivos. Sabemos que o cérebro pensa porque o corpo lhe jorra conteúdos essenciais, alianças cognitivas com o que nos envolve no meio circundante. Mas o cérebro só pensa pela mediação do corpo, ou seja, as emoções participam da racionalidade. Se como o corpo, a mente não está à mercê de intencionalidades externas, passíveis de formatação, qual é o espaço da educação como formadora da mente? Os educadores dizem que na verdade, a intenção primeira presente na idéia de formação é transformar, ou seja, aplicar uma nova forma ao caráter do indivíduo ou passar de uma forma a outra (MORAES, 1999). Embora o grande álibi da educação seja de fato a transformação, não é somente este prefixo que estabelece a ação educativa. Outros prefixos e sufixos a orientam: formar, reformar, transformar, deformar, formatar.

Apesar da noção de transformação carregar consigo um apelo de ultrapassar uma forma existente, a práxis da educação caminha para uma mudança para enquadrar em um mesmo tipo. Mesmo nas propostas que tem na escola uma esperança revolucionária, está presente esta perspectiva de servir à sociedade em categorias preestabelecidas. 
Como a educação pode ser revolucionária e aproximar-se da sociedade? A resposta veio do mercado e não da escola. As mudanças técnicas e tecnológicas acontecem cada vez mais em um período menor de tempo. Assim, diz o mercado que é mais importante que a educação prepare para a vida, eduque um indivíduo capaz de produzir significados, resolver problemas, ter liderança, saber trabalhar em grupo, do que enquadrá-lo num tipo comum, que saiba as técnicas profissionais. Tal conscientização vinda do mercado, hoje norteia as discussões dos Governos e da sociedade internacional que lançaram em outubro de 2005 a Iniciativa de Alfabetização para Empoderamento ${ }^{10}$ (cuja sigla em inglês é LIFE). Trata-se de uma estratégia de ação global para implementar a Década da Alfabetização das Nações Unidas e cumprir o quarto item da Declaração de Dakar (reduzir pela metade o analfabetismo entre adultos no mundo até 2015). Nesta perspectiva que valoriza o desenvolvimento autônomo do indivíduo, ainda com o sentido de fazer passar de uma forma a outra, porém esta outra é desconhecida e não intencionada, o caráter formativo da educação seria um processo de exposição, de trazer para fora as potencialidades de cada aluno, ao contrário do processo autoritário, da escola, do adulto, do professor para o aluno. Mais do deixar aflorar potencialidades, a educação acontece na interação interpessoal, numa rede de relações entre o indivíduo e o mundo, o mundo e o indivíduo.

As questões do ensino institucionalizado na escola ainda permanecem abertas, e a inquietude pedagógica inicia-se logo nos primeiros anos escolares com a alfabetização. Como ensinar a ler e escrever? Qual a importância de saber ler e escrever? Ler, escrever e contar é um tripé da educação desde os tempos da Grécia Clássica, e estes três verbos continuaram sendo lema na Idade Média, na Revolução

\footnotetext{
${ }^{10}$ O termo vem do inglês "empowerment" que entrou em voga na década de 1990, muitas vezes com apropriação indevida por parte de governos e agências multilaterais ao embrenharem-se no terceiro setor. Em Administração, a designação é o processo pelo qual as pessoas, as organizações, as comunidades tomam consciência de assuntos de seus interesses, de suas habilidades e vocações, a capacidade própria de produzir, criar e gerir, conquistando autonomia sobre os rumos e processos que influem na vida de uma pessoa ou da comunidade.
} 
Industrial e também agora na era da Eletrônica. Por ora, temos a impressão de que os verbos designam a mesma coisa. $\mathrm{O}$ real significado, no entanto, se modifica na medida em que se espera um comportamento do leitor, o qual é determinado socialmente, de acordo com certa época ou cultura. Na Antiguidade clássica não se esperava o mesmo que no século 18 , nem o que se espera agora. O que se espera vai além da alfabetização, da mera aquisição e reconhecimento de palavras. Atualmente, fala-se da alfabetização como um processo contínuo, e este período, a logo prazo, vindo depois do aprendizado de descodificação, é o chamado letramento. É neste letramento que nasce o leitor. Ou seja, a formação desejada de leitores acontece no cultivo das práticas sociais que usam a escrita e a leitura. Portanto, a alfabetização é um passo importante, mas não o único.

$\mathrm{Na}$ busca de uma fórmula, por determinados períodos de tempos, um ou outro método de ensino prevalece e torna-se a metodologia universal. As fórmulas e modelos são logo revisados quando começam a surgir os efeitos de inadaptação dos alunos aos métodos: altos índices de repetição na primeira série do ensino fundamental, e deficiências de leitura e escrita naqueles que conseguem ir adiante nas séries escolares e que engrossam o índice de analfabetos funcionais. Aconteceu com a universalização do método pedagógico construtivista, em relação ao fônico. $\mathrm{O}$ método fônico implica o uso da cartilha e o ensino da língua a partir da correlação entre fonemas e sílabas. Considerado ultrapassado por fazer uso do ensino por repetição, o parâmetro foi trocado pelo chamado sócio-construtivismo, em que as crianças experimentam a língua primeiro como um elemento do seu cotidiano, através de leituras e histórias contadas. O modismo se espalhou, substituindo-se o fônico pelo construtivista.

No início de fevereiro de 2006, as metodologias de alfabetização novamente estão sendo questionadas com a promulgação da lei que amplia o Ensino Fundamental de oito para nove anos. A lei implica em uma revisão dos Parâmetros 
Curriculares Nacionais (PCNs) e volta à tona a discussão sobre a maior eficiência do método construtivista em relação ao fônico. Afinal qual método é o melhor, qual deve ser adotado nas escolas?

Todos os métodos serão insuficientes, porque a criança, como ser humano, dotados da capacidade de criatividade ${ }^{11}$, vai além. Da mesma forma que o professor, dotado da mesma capacidade, tem no ensino possibilidades infinitas de pedagogia, que nascem, como nos ensinou o legado bakhtiniano, de um princípio dialógico, estabelecido nas Ciências Humanas, também como método. Mas dialogismo apenas como método, este também é insuficiente. Mais do que paradigma, o processo dialógico deve ser acima de tudo uma visão de mundo, para perceber que a definição do "método" é particularizado nas individualidades do aluno, do professor e do momento da aula.

Se existem questões abertas nos primeiros anos escolar de contato com as letras, estas não se ajustam nos anos conseguintes, no chamado letramento. As mesmas questões e problemáticas reverberam durante todo ensino fundamental e médio, por vezes no superior, quiçá pelo resto da vida de milhares de leitores. Neste contexto de não práticas de leitura legitimada na escola, o que dizer do histórico de leitura de cada aluno experimentado no ambiente institucionalizado da escola?

Quando cursei o $2^{\circ}$ grau colegial, o período de três anos do ensino médio, de 1996-1998, optei pelo currículo que possuía maior número de aulas da área de Exatas, com a perspectiva que esta escolha me ajudaria a passar no vestibular - da Fuvest - por ter o ensino "mais forte", "mais puxado". Descobri que a diferença das áreas estava na contratação de professores. O ensino de exatas no Instituto Adventista de Ensino era

\footnotetext{
${ }^{11}$ Ilya Prigogine, químico russo-belga, ganhador do Prêmio Nobel em 1977, em Diálogo com
} sábios e cientistas, de Renee Weber, nos diz que toda a natureza é dotada da capacidade de criatividade, ou seja, toda semente é aparentemente igual, mas não existe uma árvore igual a outra. 
mais forte porque se investia nos melhores professores. Os professores das disciplinas de Física, Matemática e Química mantinham um projeto integrado e multidisciplinar. Entre as metodologias utilizadas, a que mais deixou seu legado, não só em mim, mas em todos meus colegas de classe, seja por acatarem ou por acharem um método nãodidático - alguns diziam que era uma forma do professor não "dar aula" -, era a leitura da matéria em livros, para que antes de demonstrar fórmulas e resolver exercícios, os alunos entrassem em contato com a teoria, com os conceitos antes de partirem para a prática. De fato, os livros didáticos, ao contrário do que o nome nos levavam a crer, não se preocupavam em ser muito "didáticos", mas os professores insistiam que lêssemos, duas, três, quantas vezes fossem necessárias. Os quinze primeiros minutos iniciais das aulas eram dedicados à leitura, algumas vezes individual, outras em grupos pequenos formado de quatro a seis alunos. Na maioria das situações estes minutos findavam e a classe continuava com uma imensa incógnita, e o professor, em especial o de Matemática - seu nome era Ivanildo Gomes de Prado ${ }^{12}$, na época, mestre pela Universidade de São Paulo -, diante de tantas interrogações, abria o livro na página indicada, e, em voz alta, caminhando pela sala, fazia pausadamente sua leitura. Somente após todo este ritual ia-se à lousa e às continhas. Hoje, ao recordar destas aulas, acho mais surpreendente do que matérias da área de exatas serem ensinadas fazendo-se leituras de textos, é o fato de eu não me recordar de algo semelhante, em doze anos de ensino fundamental e médio, em nenhuma aula de português, literatura ou redação. Algumas vezes nas aulas de geografia, história e até mesmo biologia. Mas nunca nas aulas mais evidentes. Algo parecido a respeito de leituras realizadas na escola, acontecia no ensino pré-escolar, o "prézinho". Quando entrei em contato com as cartilhas, as leituras, muitas vezes gaguejando, eram feitas tentando-se decifrar as letras e vogais que

\footnotetext{
${ }^{12}$ Professor-doutor com pesquisa em Ensino-aprendizagem de Matemática.
} 
apareciam delineadas por quadrado recortado em um papel sulfite. Decifrava e procurava o olhar de aprovação da professora.

Embora o histórico de leituras em escola tenha sido particularizado em mim, as experiências de leituras nas escolas se repetem e perpetuam. Os relatos são parecidos. Por parte dos alunos, não há memórias de leitura acontecida na escola. Quanto aos professores, sentem-se pressionados por programas panorâmicos, obrigados a cobrir toda a linha do tempo, fazendo uso da história da literatura, ainda que isso não dê resultados significativos: aulas chatas, alunos e professores desmotivados, aprendizagem que não corresponde ao que em princípio foi ensinado. Dedicar tempo à leitura em si seria perder tempo. Tempo que deve ser aproveitado para cumprir o cronograma dos programas, e nunca para a leitura vagarosa da literatura, pensando-se no romance como exemplo.

Algumas tentativas, no âmbito dos estudos literários, procuram dimensionar o papel do professor como mediador de leitura, estimulador e apoiador à leitura, não apenas da dita literatura, mas de textos e narrativas, poesias, textos para teatro, roteiros de cinema, e outras diferentes linguagens que dialogam entre si. A escolha deve estar ligada tanto às exigências curriculares dos projetos pedagógicos da escola quanto às preferências pessoais. Pois ainda hoje, o ensino de português resume-se à gramática e o de literatura aos conhecimentos de autores e escolas literárias, raríssimas vezes ao texto em $\mathrm{si}^{13}$. Há uma sobrecarga nos alunos com informações sobre a época, estilos e características de escolas literárias, da literatura tornado objeto de estudo racionalizado, um diagnóstico citado também nos PCN:

\footnotetext{
${ }^{13}$ A organização dos livros didáticos denuncia o grau de importância dado aos tópicos de ensino de Literatura. Em geral, inicia-se o capítulo com uma rápida contextualização histórico-social que justifica a classificação em escolas literárias, citam-se as principais obras, explora-se o currículo e a vida dos autores. Raras vezes, no final dos capítulos, encontra-se um trecho de uma obra, e quando sim, não é para fruição, aproveita-se o ensejo para vincular o texto a um exercício de gramática.
} 
Para além da memorização mecânica de regras gramaticais ou das características de determinado movimento literário, o aluno deve ter meios para ampliar e articular conhecimentos e competências[...] $\left(\mathrm{PCN}^{+}, 2002, \mathrm{p} .55\right)$

Assim, é urgente que o professor, ele próprio, se abra para as potencialidades da literatura e faça um esforço para se livrar dos didatismos que o obrigam a passar aos alunos um conteúdo mensurável e visível, como acontece no ensino das escolas literárias, não sobrando tempo para a prática da leitura. Em sua dissertação, a pesquisadora Regina Lúcia da Silva Nascimento (2001), com uma análise dos dados guiados pelas noções teóricas que envolvem texto, leitura e interação, fornecidas, principalmente, pela Literatura e pela Linguística Aplicada, mostra que a interação em sala de aula, ainda que num período de tempo curto, permite ao aluno uma manifestação mais livremente e, assim, este vai além do processo de decodificação e repetição pura e simples do manual, ainda muito presente na aula de leitura.

Em que faixa etária a leitura deve ser introduzida? Na pré-escola ou no ensino fundamental? A convicção de muitos pesquisadores é de que, quanto antes for plantado o gosto pelos livros, maior será a chance de que a criança se transforme num adulto leitor. Assim, não é necessário esperar que a criança entre na $1^{\mathrm{a}}$ série para que seja apresentada ao mundo do livro e da leitura. De fato, a familiarização com o mundo das escritas é feita pelo contato, não necessariamente lúdico, mas primordialmente afetivo, pois, numa visão piagetiana, a afetividade, por prazer, mobiliza uma ação de busca individualizada, de interesses e de conhecimentos. Neste contexto, os comportamentos exemplares são fundamentais, pois a presença de livros em casa e na escola, o incentivo dos pais e dos professores podem ser fatores que influenciem o desenvolvimento do gosto pela leitura. Porém, a relação nem sempre é tão direta e nem tão simples. Há casos de pais que têm o hábito de ler e o valorizam, mas o mesmo não acontece com seus filhos, e, vice-versa, quando uma criança vinda de um ambiente familiar de onde não 
recebeu esse estímulo pode se tornar leitora. Espelhar-se em valores presentes nas suas redes de interlocução é um dos fatores estimulantes, mas não o único. Todos, inclusive as crianças, possuem liberdade individual para fazer seu próprio percurso de leitura. Esta busca de um percurso personalizado é possível, como mencionado, quando a leitura estiver associada a momentos de prazer. O fenômeno que acontece com os alunos dos ensinos fundamental e médio, tido como desgarramento e desafeto à leitura, não acontece nos primeiros momentos de aprendizagem, nos primeiros anos de ensino. Estes estão repletos do entusiasmo da descoberta de um mundo possível em letras. Ocorre, sim, quando lhes são apresentados os clássicos, transformando a leitura de um ato fruidor para um ato racionalizado e obrigatório a ser cobrando como conteúdo de prova.

Qual a visão que se têm a respeito de literatura como disciplina curricular? Qual é o espaço da leitura na escola? Por que não se começa o conteúdo literário dos contemporâneos, que será provavelmente a leitura mais próxima, que mais propensa a criar uma identificação com o leitor? A resposta é que estes ainda não se tornaram clássicos. O que são os clássicos? Por que é tão vital que leiamos os clássicos? De que substâncias tão preciosas são feitos os clássicos que os fazem ser leitura obrigatória? Por que se defende tanto a leitura de literatura clássica? Um significado bem humorado seria definir a palavra "clássico" como um adjetivo de tudo aquilo dado em classe. E o "tudo aquilo" é determinado pela lista dos exames de vestibulares. Então, em última instância, é o vestibular que diz o que deve ser lido, as obras que são mais clássicas que os outros clássicos. Outra justificativa muito recorrente é que em um país de poucos leitores, as indicações de leituras e as exigências, veladas ou não, de que se leiam os clássicos, é um estímulo para que tenhamos leitores, ainda que leitores artificiais, aborrecidos pela imposição, sem experenciar a literatura. 
No dicionário Aurélio encontramos dez acepções sobre o que viria a ser literatura, no sentido do verbete. A primeira explicação foi dita anteriormente, na citação aos PCN, arte de compor ou escrever trabalhos artísticos em prosa ou verso, porém para os fins pedagógicos presos ao conteúdo visível, esta cai no paradoxo da indefinição da utilidade da Arte. A seguinte, conjunto de trabalhos literários dum país ou duma época, valoriza o texto em si e contexto histórico, a data em que este foi produzido, sua escola literária. O terceiro significado, os homens de letras, parece dizer, de uma maneira figurativa, a respeito dos autores, assim como os dois seguintes: a vida literária e a carreira das letras, e neste a importância é dada ao autor e não à obra, e a leitura não se encaixaria. Na sexta definição a literatura transforma-se em objeto de abstração e estudo: conjunto de conhecimentos relativos às obras e aos autores literários. Na sétima, finalmente encontramos algo semelhante à noção de fruição literatura é qualquer dos usos estéticos da linguagem. E o que é a estética senão a fruição, que do grego, aisthesis, quer dizer simplesmente perceber, sentir. Encontramos um significado figurativo na oitava definição, quando a palavra se torna sinônimo de irrealidade, ficção. De certa forma uma boa interpretação, se ao invés de compreender ficção como tudo aquilo que é mentira, considerar-se irreal aquilo que não pertence ao mundo real mencionado por Bakthin (1993), ou a segunda realidade de Kosoy (1989), e ainda a produção simbólica por Medina (2003). Os dois últimos significados são menos abrangentes: no sentido de bibliografia (A literatura de Física Nuclear é bem extensa), e, em um uso técnico, é o nome dado ao conjunto de escritos de propaganda de um produto industrial. Algumas enciclopédias acrescentam que literatura são as obras cujos valores foram postos à prova do tempo. Indicação bem intencionada, mas arbitrária e retórica. O fato é que uma obra só se perpetua enquanto tiver leitores, for lida, acontecer na leitura, e não apenas referida. 
Somente esta última explanação se aproxima da limitação em dizer que literatura são os clássicos. Em que esfera social definem-se quais são os clássicos? Seriam os escritores os legitimados a dizer que obras são clássicas, por suas proximidades ao ato de escrever, pela familiaridade do assunto? Ou seriam os críticos, os etiquetadores maniqueístas da boa e da má literatura? Seria muito caótico se cada um fizesse suas próprias escolhas. Com certeza, os títulos seriam incontroláveis, uma vez que oferta aumenta a cada dia. O primeiro contato com determinado texto, autor ou obra pode acontecer no ambiente escolar, com o incentivo do professor, mas a sentença final de escolha, como de qualquer leitor, é do aluno, sempre. O histórico de leitura sempre será individualizado.

Se a literatura existe através de textos, certamente, a leitura ou os modos através dos quais ela foi e é lida prefiguram os sentidos que ela teve e pode vir a ter. De forma que, hoje, seria pouco proveitoso pensar no literário sem considerar sua natureza social ou as complexas forças que ajudam a construir aquilo que se chama literatura. A epistemologia nos diz que conforme a perspectiva que se adote, o mesmo objeto pode ser concebida de maneiras diversas. A Literatura não foge à regra. Muitas conceituações foram formuladas, mas nenhuma será completa e definitiva, pois cada época ou cada teórico fundamenta-se em uma determinada forma de conhecimento da vida, da arte, da palavra, dos valores do mundo e da condição humana. Mas, algumas delimitações podem ser feitas, por exemplo, ao se pensar sobre a leitura na escola, deve-se considerar que esta instituição promove uma maneira particular de leitura, a leitura "ensinada" e "aprendida", desenvolvida pelos alunos e mediada pelo professor.

Nos Parâmetros Curriculares Nacionais de Ensino Médio, os conteúdos de literatura como disciplina foram incorporados aos estudos da linguagem, o que gerou polêmica junto aos professores de literatura que argumentavam a anulação da autonomia e da especificidade de tal disciplina. Quais seriam estas especificidades? É o 
que registraram as docentes Neide Luzia Rezende, Maria Zélia Versiani e Enid Yatsuda Frederico, em manifestação apresentada ao Ministério da Educação. A primeira especificidade estaria no conceito do que é literatura. No sentido lato sensu, tudo o que é escrito é literatura, assim fala-se em literatura médica, literatura científica etc. Porém, para se discutir o currículo de Ensino Médio, a literatura foi adotada em seu sentido stricto sensu, é algo próximo ao descrito na principal definição do dicionário Aurélio; enquanto arte que se constrói com palavras, arte de compor ou escrever trabalhos artísticos em prosa ou verso. Mais adiante, ainda neste artigo, o problema da literatura persiste ao se perguntarem, professores e alunos - teóricos e pesquisadores -, se a literatura é indispensável para quê e, se é arte, para que serve a arte? Adentraremos com maior afinco no último capítulo em que tratarei a literatura como arte, mas já posso dizer que talvez a pergunta central não seja essa, como desenvolvi no primeiro capítulo, com base no trabalho da pesquisadora Tereza Cruz. Ao questionar para que serve a literatura estamos buscando uma funcionalidade para a literatura, e melhor seria perguntar para quem, uma vez que a arte, e a literatura, são manifestações humanas de fruição e de transcendência da própria humanidade. A literatura só possui sua existência quando fruída, apropriada pelo humano ser, que lhe dá o fôlego de vida aos signos, lendo-os, fazendo-os acontecer. Nas palavras de Antonio Candido:

A literatura desenvolve em nós a quota de humanidade na medida em que nos torna mais compreensivos e abertos para a natureza, a sociedade, o semelhante. (1995: 249).

Outro fenômeno nas leituras escolares, registrado por Regina Zilberman (2003) em seu artigo em que discute o conceito de letramento literário ${ }^{14}$, é que a leitura de literatura vem se diluindo entre outros tipos de discurso ou de textos, especialmente os

\footnotetext{
${ }^{14}$ A definição é dada por Magda Soares (1998,18): “estado ou condição de quem não apenas sabe ler e escrever, mas cultiva e exerce as práticas sociais que usam a escrita".
} 
classificados como jornalísticos, e por substituição da obra por resumos e compilações, que privam a experiência literária, o contato afetivo com o livro e com o texto. Somente a leitura de um texto num estado de fruição estética pode estimular sensações, causar estranhamento, gerar empatia ou apatia. Os resumos e publicações "simplificadas" partem do pressuposto que há uma necessidade social que se conhecer as histórias dos clássicos, das obras que ganharam notoriedade e se tornaram olimpianas. Porém, mais que saber o enredo, facilitar a literatura pressupõe uma leitura definitiva oficializada por acadêmicos e críticos - que define como determinada obra deve ser lida, e, com este parâmetro formato, há uma inferioridade dos alunos enquanto leitores que não serão capazes de entendê-la em seu estado original, sem técnicas e sem conhecimento prévio. Na concepção de Roland Barthes (1978), a essência da literatura está na utilização da linguagem livre do poder. A linguagem literária não pode ser submetida ao poder, é fruto justamente da não-racionalidade humana, do inconsciente, e não necessita de regras de estruturação para se fazer compreender. Todo e qualquer poder imposto é abstrato, só existe na concepção do impositor. Burlá-lo é a regra geral, pois não existe leitura definitiva, cada leitura é única. E se a literatura só existe porque acontece em uma leitura, e a leitura só acontece se há um sujeito, o domínio da literatura está no sujeito-leitor, e não no ditador de regras, em forma de abstração teórica ou personificado. A medida que há esforços para que se criem regras para cobrança desta leitura coincidente com a leitura definitiva oficializada, com provas e notas, em uma proporção maior e mais criativa procuram-se alternativas de escapar destas regras, por exemplo, lendo resumos e repetindo, com excelência suficiente para uma boa nota, aquilo que é o esperado pelo avaliador.

A falência do sistema institucionalizado na escola não significa que a literatura não está acontecendo fora, em outras esferas sociais e privadas. $\mathrm{O}$ registro de leituras 
"fora da escola" em geral se liga à ficção ${ }^{15}$, gibis, livros de literatura infantil e juvenil, todos fora do leque canônico (MARTINS, 1999). Este é o fenômeno inerente à construção do percurso de um leitor. É ele quem escolhe os títulos, os autores, as páginas, as palavras que deseja ler. Manipular e controlar esta escolha é impossível, porque nem mesmo nós leitores sabemos como funciona esta complicada rede mental acionada na leitura que estabelece nexos com outras leituras. Portanto, não se pode afirmar que a construção do repertório de leitura extracurriculares dos adolescentes, de acordo com estudos recentes (PETRUCCI, 1999), recusa os cânones da literatura e migram para uma desordem, de escolhas aleatórias, chamada de "escolhas anárquicas", sujeita a desejos imediatos, "que surgem com a velocidade de um olhar sobre um título sugestivo ou sobre uma capa atraente". Ainda que se tente tabelar os valores literários, quem constrói a coerência é o aluno-leitor, e as escolha, olhando de fora, são tão “anárquicas" quanto de qualquer outro leitor.

Voltamos ao sétimo significado proposto no Aurélio que fala sobre a literatura, como qualquer dos usos estéticos da linguagem. Este é o ponto em que os educadores se debatem. Apesar de assumirem que o prazer estético é parte da literatura, deixar que a aluno faça seu próprio discernimento é não ter controle sob os critérios aferidos, e não saberem diferenciar um texto literário de um "texto de consumo", ou seja os best sellers - e qual é o problema dos best sellers? Que autor não gostaria de ter sua obra na lista dos mais vendidos? Um texto só é texto quando acontece por meio do leitor, quando é consumido. Assim, mais importante que o ato de ler, é o julgamento do que é bom. Aos olhos dos educadores, com objetivos preestabelecidos em suas atividades, uma leitura solta, de fruição e sem orientações quanto à estrutura e sua função, é vista como uma leitura ingênua, incompleta, e assim, inválida. A questão surge no que vem a ser a

\footnotetext{
${ }^{15} \mathrm{O}$ conceito de obra de ficção pode ser questionado. Se como é muito comum, diz sobre ficção como "uma história imaginada", adquiri uma conotação imprópria, uma vez que todo texto, literário ou acadêmico, é irreal, produção simbólica, e existe enquanto elementos abstratos em um papel. O texto não é exclusividade da palavra escrita.
} 
fruição estética. Ao propor que se façam momentos espontâneos de leitura coletiva de uma obra literária, uma sessão de um filme, e de preferência fora do ambiente de sala de aula, os $\mathrm{PCN}^{+}$a definem:

Desfrute (fruição): trata-se do aproveitamento satisfatório e prazeroso de obras literárias, musicais ou artísticas, de modo geral - bens culturais construídos pelas diferentes linguagens depreendendo delas seu valor estético. Apreender a representação simbólica das experiências humanas resulta da fruição dos bens culturais.

E o debate vem a posteriori, no Manifesto da Escola de Educação da Universidade de São Paulo em resposta aos Parâmetros Curriculares Nacionais:

Conceituado dessa forma, o prazer estético proporcionado pela fruição pode ser confundido com divertimento, com atividade lúdica simplesmente (talvez por isso se aconselhe o seu desfrute fora da sala de aula), deixando espaço para que se compreenda o texto literário apenas como leitura facilmente deglutível. Não podemos confundir prazer estético com palatabilidade (...)

Neste trecho levanta-se uma polêmica da Educação: o lúdico como pedagogia. Apesar de muitos trabalhos acadêmicos terem mostrado a importância da emoção na aprendizagem, na necessidade de romper o paradigma da educação atrelado ao ato de haver uma pessoa legitimada, o professor, a fonte detentora do conhecimento que transmite este saber, que repassa informações aos alunos; embora esteja se estabelecido - na práxis - em vários setores da sociedade, principalmente no mercado, com destaque para as multinacionais, a noção de lúdico ganhou uma conotação de ociosidade.

A palavra lúdico vem do latim ludus e significa jogo, e, talvez por isso, tenha tido associações das noções de brincadeiras e divertimento. Em época de domínio da mercadoria e da produtividade, ditados pelo tempo e o modo de produção, a brincadeira, 
o divertimento, a arte, e ainda que seja o ócio, são inadmissíveis. A racionalidade do pensamento linear ainda prevalece sobre a intuição sintética e poética, como instrumento de aquisição de conhecimento. Talvez este seja o motivo da não aceitação da ludicidade como uma necessidade do ser humano, e da não compreensão do aspecto lúdico na aprendizagem, não como facilitador, mas como substância para a construção do conhecimento (ROJAS, 2002). De acordo com o conceito de inteligência emocional desenvolvido por Goleman (1999), aprendemos e apreendemos quando se trata de assuntos que nos interessam, nos divertem e nos proporcionam prazer. Ambos são importantes, a razão e a emoção, um para sistematizar e outro para mobilizar. É pela emoção, através dos cinco, ou mais, sentidos, que interiorizamos o mundo em nós. O conhecimento excessivamente técnico nos leva ao que o psicanalista Restrepo (1998) chamou de analfabetismo afetivo, uma atrofia de, pelo menos, três sentidos humanos: olfato, paladar e tato. A sociedade contemporânea tem dado muito mais atenção aos sentidos da audição e da visão, provenientes de exteroceptores, ou seja, receptores à distância. Distante duplamente: física e afetivamente, uma vez que apenas se ouve aquilo que passa pelo nosso crivo, o que convém.

A ciência, com seu esquematismo alienado da dinâmica vital, nos faz crer que só podemos conhecer se decompusermos o outro detendo o movimento com a metodologia que aplicamos diariamente, tanto na pesquisa biológica quanto social, estendendo-se além de tudo à vida afetiva e à nossa relação com o mundo. (RESTREPO, 1998: 14).

A questão do analfabetismo afetivo, da proxemia do Eu e do Tu por meio do toque - do corpo ou da sensibilização, concreto ou abstrato, mas ambos um movimento de aproximação - ainda se apresenta ao constar que os professores também não possuem uma ligação especial com livros e leituras, havendo carência da prática pessoal 
da leitura. Este analfabetismo afetivo, de estar afeto à leitura, torna-se um complicador na mediação da leitura, como defendem alguns pesquisadores ${ }^{16}$ : o ensino de literatura e o gosto pela leitura passam pela epiderme, ou seja, quem não gosta de ler não conseguirá suscitar a leitura no Outro. Se aos professores (bibliotecários, e todos os mediadores da sociedade) não lhes é impossível usar o "método da epiderme" apenas sobra-lhes, para cumprir o programa curricular, a tarefa de obrigar os alunos a ler. E a ler aqueles títulos que os identificarão como leitores: os clássicos.

De alguma forma, o lúdico se faz presente e acrescenta um ingrediente indispensável ao relacionamento entre as pessoas, possibilitando que a criatividade aflore, e é na interação afetiva auxilia na compreensão das pessoas, mais do que um raciocínio brilhante, repassado mecanicamente. Interação é uma palavra-chave que muda a visão da diversão como ócio improdutivo - e esta produtividade é questionável - para uma visão de relação interpessoal dialógica, ainda que esta outra pessoa seja o próprio indivíduo: interagir consigo mesmo. O jogo possibilita uma quebra na hierarquia estabelecida pelos condicionamentos do dia-a-dia, toda postura dominadora fica de lado, aquele que quer compreender deve ser capaz de ouvir o outro, numa relação de alteridade, sem hierarquia, com igualdade de condições, para com ele estabelecer um diálogo. Este jogo-diálogo acontece também na leitura, quando todos os elementos se interagem e acontece uma epifania. Portanto, o lúdico é intrínseco ao ato de ler. Paulo Freire possui uma vasta pesquisa no campo da Educação, e de maneira especial da ludicidade como pedagogia, e é ele, em Professora sim, Tia não (1997, 56), quem nos alerta:

... é necessário que evitemos outros medos que o cientificismo nos inoculou. O medo, por exemplo, de nossos sentimentos, de

${ }^{16}$ Hipótese defendida pela professora Anna Maria Cintra, docente da Universidade de São Paulo em Biblioteconomia, na palestra "Bibliotecários, mediadores de leitura", no dia 12.03.2006, no Fórum PNLL 2006/2008, realizado pelo projeto Vivaleitura. 
nossas emoções, de nossos desejos, o medo de que ponham a perder nossa cientificidade. $O$ que eu sei, sei com o meu corpo inteiro: com minha mente crítica, mas também com os meus sentimentos, com minhas intuições, com minhas emoções.

No meu entender, poderíamos dizer que o ensino de literatura, por não admitir o lúdico, nem a autonomia do aluno, tanto na interpretação quanto nas escolhas - que estará sempre em transição e cabe ao professor estimular, pela vivência da leitura e de leituras, e não pelo convencimento e obrigação -, não está preocupado com a fermentação de leitores, assim, como a alfabetização também não. No âmbito institucional da educação e da cultura, parece haver uma reação defensiva em que preocupa mais a falta da leitura do que a sua realização e verificação de quando e como ela acontece, já que alguma leitura quase sempre acontece, mesmo não sendo a preconizada.

Historicamente, a leitura correspondeu, durante séculos, ao percurso do livro na humanidade. É possível dizer que esta raiz histórica seja o motivo para o qual, no século 21, com tantas mudanças tecnológicas no modo de produção, ainda se associe fortemente a leitura à linguagem escrita, e, para alguns, à escrita em livros. Talvez por isso se tenha construído este privilégio da literatura sobre as demais artes, atingindo o Olimpo, a partir do século 19, época em que a literatura assumiu o papel de expressão artística e cultural de um povo. Nos séculos 18 e 19, vários países haviam passado por processos de independência, tinha-se a necessidade de constituição de uma identidade nacional, função dada às artes em geral, porém, naquele momento, a produção escrita ocupava uma posição de destaque, pois era a mais acessível economicamente, e, portanto, a mais pública das formas de expressão artística. Além disso, a literatura vinculava-se a outro argumento em prol da autonomia: a língua nacional. A difusão 
social, como é mencionada no senso comum e também na academia ${ }^{17}$, da produção literária embute, requer necessariamente, uma escolarização, dando origem aos cursos de história da literatura nacional. Ler e apreciar a literatura erudita nacional e a universal, passou a ser visto como algo fundamental para a formação cultural do sujeito. Isso, de certa forma, contribuiu para que houvesse a sobrevalorização da literatura, e, concomitantemente a da literatura de livros clássicos. Há quase cinquenta, Robert Escarpit (1967:179) sugeriu que as condições técnicas possibilitavam que a universidade e a escola utilizassem variados produtos culturais, deixando de ater-se exclusivamente à literatura, tomando-a como único meio de "difusão de massa". Dentro do século 21, numa contemporaneidade que valoriza a informação, a escola parece ignorar a extrapolação de possibilidades da leitura e a potencialização das diferentes linguagens, uma vez que podemos afirmar que o texto não é exclusividade da palavra. Citado por um de seus biógrafos (BRAIT, 1997), Mikail Bakhtin, com sua teoria do dialogismo, sugeria a idéia de texto-tecido que comporta diferentes códigos e permite o cruzamento de diferentes gêneros; o texto é sobretudo humano e diz respeito à toda produção fundada na linguagem.

Não há nem primeira palavra nem derradeira palavra. Os contextos do diálogo não têm limite. Estendem-se ao mais remoto passado e ao mais distante futuro. Até significados trazidos por diálogos provenientes do mais longínquo passado jamais hão de ser apreendidos de uma vez por todas, pois eles serão sempre renovados em diálogos ulterior. Em qualquer momento presente do diálogo há grandes massas de significados esquecidos, mas estes serão de novo reinvocados em um dado momento no curso posterior do diálogo quando ele há de receber nova vida. Pois nada é absolutamente morto: todo significado terá um algum dia o seu festival de regresso ao lar.

17 Veremos mais adiante que o Signo da Relação vê a divulgação ou a difusão como um paradigma autoritário dominado por um vetor de sentido único proveniente de uma fonte legitimada. O desafio é construir elos e sentidos e visualizar os signos sempre dentro de um contexto de relações humanas. 
Se para Bakhtin o texto é signo, é preciso diferenciar a noção de signo adotado pelo autor. Para a semiótica de Charles Peirce, o signo está no lugar de algo e o representa. Ora, para Bakhtin, a signicidade do signo surgirá do processo dialógico. Ou seja, estimular bons leitores não pode ser uma tarefa presa à palavra escrita em um livro, num suporte de papel. É necessária, também, uma rica experiência de convivência com a música, a pintura, a fotografia, o cinema e outras formas de utilização dos sons e das imagens, outras produções simbólicas, outras artes, outras literaturas, que procuram organizar e compreender o mundo. Essas linguagens não são alternativas, mas complementares, elas se articulam. É essa interdependência, identificado em fenômenos de leituras extracurriculares - Harry Porter, O Senhor do Anéis, O Código da Vinci e outros $^{18}-$, que devem ser exploradas no ensino de leitura, quando o objetivo é fermentar leitores. Porém, no século 21, a escola ainda parece ignorar a extrapolação de possibilidades da leitura e a potencialização das diferentes linguagens. Os livros não são mais os meios de "difusão" cultural mais disseminados, como ocorria no século 19. Do ponto de vista social, geográfico ou etário, o rádio e a televisão ocuparam esta função do livro. E se o acesso à TV já alterou bastante o nosso processo de buscar informações, e a nossa necessidade de ficção, o final do século passado prenunciou uma espécie de mutação nos processos daquilo que vem (ou vinha) sendo considerado como ato de ler, desde que, no século XV, Gutenberg inventou a tipografia. Se considerarmos o fenômeno Internet, atreveríamos a dizer que outro quadro pode estar surgindo, pois o ato de ler transforma-se historicamente, e hoje, por influências das tecnologias essas mudanças são aceleradas. Ainda que o livro e a leitura mantenham seu lugar específico, pois nenhuma tecnologia substitui a outra, como aconteceu com o rádio e a TV, e vemos agora com a Internet, continuamos sem saber como se lê, quem são e como são os leitores de nosso tempo.

\footnotetext{
${ }^{18}$ Livros com versão cinematográfica.
} 
Se é que a escola quer formar leitores, o leitor almejado é aquele que Umberto Eco (1989) identificou, no final da década de 1980, como o leitor crítico, em contrapartida ao leitor vítima. Este último estaria mais interessado no conteúdo do texto, na estória, e é chamado de vítima porque é capturado pelo enunciado, enquanto o leitor crítico estaria interessado no modo de enunciação. Embora o leitor vítima seja associado a uma leitura dita mais leve, geralmente relacionado aos chamados livros de consumo ${ }^{19}$ - um policial ou livro de suspense, gêneros mais propensos a capturar o leitor, que o percorre avidamente até o final para descobrir o culpado, sem se preocupar muito com as inconsistências da narrativa e todos seus problemas de construção (ECO,1989:132) - não podemos nos esquecer que o próprio Eco, na construção do conceito de leitor crítico, diz que o leitor vítima preexiste ao leitor mais atento, exigente, crítico. E mesmo quando o segundo se constitui, os dois tipos básicos de leitores - a vítima e o crítico, mas não só estes -, coexistem.

O primeiro é a vítima designada pelas próprias estratégias enunciativas, o segundo é o leitor crítico, que ri do modo pelo qual foi levado a ser vítima designada. (ECO, 1989: 101).

O fato é que os momentos de leitura solta e descontraída são vistos como desperdício de tempo, uma vez que há um script, com conteúdos sobre escolas literárias, autores e obras - no plural porque são dadas em listagem - a ser passado ao aluno. Pelo mesmo motivo, quando se cria um tempo para leitura de textos literários, esta leitura deve ser regida por uma finalidade específica: é a instrumentalização da leitura, da educação institucionalizada. A passagem pela educação escolar para ler e escrever implica em ir além da instrumentalização da leitura e escrita, pois ler e escrever da forma socialmente compartilhada envolve a passagem de um lugar privado de ler e

\footnotetext{
${ }^{19}$ Todo livro é livro de consumo e deseja-se que seja um best-seller, seja o consumo por meio de sua leitura ou mesmo por sua exposição como peça decorativa.
} 
escrever - a família, o indivíduo - para um lugar público, histórico-social. Lugar onde a inscrição no código social (lei social) é indispensável. Na educação escolar o sujeito tem acesso ao mundo da letra socialmente simbolizada, onde a letra não vale por si, mas pelo que representa no código socializado da cultura.

Da mesma maneira que o ato de leitura é epifânico, as questões, o objetivo, a finalidade nascem durante o ato. Quantas vezes somos surpreendidos em nossas próprias leituras, por vezes ao reler um mesmo tempo, o fato de termos passado situações correlatas diferentes de um momento para outro, faz com que leiamos diferente. É preciso estar aberto para legitimar outras leituras. Leituras que surgirão no percurso do ato da leitura. E se nas escolas a prática da leitura não é dada à Literatura, presa ao lado da historicidade da escrita literária, das escolas literárias, nem ao Português - que se restringe à leitura e interpretação de texto ${ }^{20}$ - a quem seria abnegada a leitura?

Seria a biblioteca o lugar propício para a leitura? A instituição biblioteca possuía na época da criação do Instituto Nacional do Livro, final da década de 1930, a função de propagar uma política de leitura. Mas a preocupação predominante era a preservação do material bibliográfico, e muitas se negavam a fazer o empréstimo domiciliar com receio de o livro ser furtado, e assim o profissional teria de dar conta do material permanente. O livro não era, e ainda é, somente associado à material permanente, como era também um símbolo de status intelectual do seu proprietário, evidente na encadernação. Esta mentalidade do livro como bem permanente, repetiu-se na biblioteca com o princípio da preservação eterna do livro, abnegando-a a uma função de depósito de livros. Historicamente, as bibliotecas concentram suas atividades no espaço da biblioteca ao organizar o acervo - muitas vezes defasado -, catalogando, separando, classificando, dispondo os materiais de leitura, de consulta, de pesquisa, aos seus usuários, tarefas

\footnotetext{
${ }^{20}$ Título que inclusive é tópico dos livros didáticos da disciplina de Português.
} 
ligadas ao tratamento, organização administração e controle da informação. Em seu artigo A biblioteca pública no contexto da sociedade da informação, o professor Emir José Suaiden (2000: 267) lembra:

De fato, tanto na República Velha como na Primeira República, biblioteca era sinônimo de livro. Dificilmente poderia ocorrer a uma pessoa procurar a biblioteca sem estar interessada na informação bibliográfica, e esse é um grande contraste, pois no período mencionado o ensino era muito precário e grande percentual da população era composto de analfabetos. Portanto, era um clima ideal para a disseminação de informação oral, utilitária ou sobre cidadania. Em 1912, a Biblioteca Nacional passou a ministrar cursos para a formação de bibliotecários. Era fácil perceber a preocupação com a preservação do material impresso.

Foi nas décadas de 1930 a 1950, portanto muito recente, que o governo deu indícios de democratização de livros, ao promover a edição e distribuição de livros que considerava patrimônio bibliográfico. Em seguida, passou-se a investir muito no livro didático para distribuição gratuita aos alunos da rede de ensino público. Suaiden afirma que no aspecto relativo à tradição cultural, (...) tanto no período de colonização, como na primeira República, o livro não foi considerado um instrumento valioso de disseminação cultural. As oportunidades de leitura eram raras, a falta de bibliotecas públicas associada ao custo do livro fazia com que a formação do leitor fosse sempre adiada. O papel representado pelos livros nas escolas e no sistema educacional foi sempre um papel secundário, pois não havia bibliotecas escolares, grande parte dos professores era leiga e o que prevalecia sempre era a cópia a dicionários e enciclopédias (2000: 122).

Segundo o autor, na década de 1970 é que surgiram os primeiros estudos e pesquisas relacionados com os usuários na biblioteca, e somente no final do século 20 , 
aparece uma discussão consistente sobre este princípio em que a leitura na biblioteca não é pensada, nem mesmo em seus projetos arquitetônicos próprios para acomodação de leitores. A própria formação dos profissionais bibliotecários, não apresenta em sua grade curricular, uma preparação de indivíduos conscientes de sua atividade como mediadores da leitura. O princípio de preservação de livros é tão forte na nossa sociedade que faz com que a idéia do livro descartável - o pocket book, de consumo rápido, já comuns em países como o Japão ${ }^{21}$ - ainda encontre barreiras para chegar ao Brasil.

No prefácio do livro Biblioteca pública e informação à comunidade (SUAIDEN, 1995), o professor Antonio Agenor Briequet de Lemos pergunta: para que servem as bibliotecas? No livro Conceito de biblioteca (TARGINO, 1984), fica clara a incompatibilidade das expectativas dos usuários e dos profissionais. $\mathrm{O}$ autor diz que a indústria editorial acredita que o objetivo fundamental é a formação de um público leitor, os educadores acreditam que a biblioteca deve ser o alicerce do processo ensinoaprendizagem, os intelectuais acreditam que deve ser um espaço rico em literatura de ficção. E, embora muitos digam que é uma fonte para busca de informações, os cidadãos não vêem a biblioteca como um local para solucionar os problemas cotidianos. $\mathrm{Na}$ batalha que trava para responder às inquietações da sociedade sobre o seu papel, a biblioteca, e em especial a pública, perde cada vez mais prestígio, deixando de ser o que deveria ser - de acordo com pesquisas, encontrar sua função - por tentar "ser tudo para todos". Ainda são poucas as bibliotecas públicas que elaboram diagnósticos sobre as necessidades informacionais, estudos e perfil dos usuários para adequar o acervo ao gosto do freguês.

\footnotetext{
${ }^{21}$ Uma pesquisa realizada em 2004 pelo Grupo de Pesquisas em Economia do Entretenimento do Instituto de Economia da Universidade do Rio de Janeiro (UFRJ) mostrou uma lista de países com o custo de seus livros. O país que apareceu como o mais barato foi o Japão, no qual um morador pode comprar, com uma renda média, 4.029 livros no ano. O Brasil ficou em décimo lugar, com capacidade de compra de cerca de 1500 livros por morador, na frente apenas da China e do México, onde os livros têm os preços mais caros do mundo.
} 
Não é em aula, nem na biblioteca que a leitura ganha espaço para acontecer. Por este motivo, elaborou-se para o estado de São Paulo o projeto Hora da Leitura. Em sua origem, trata-se de um Programa de Enriquecimento Curricular junto aos alunos do Ciclo II do Ensino Fundamental $\left(5^{\circ}, 6^{\circ}, 7^{\circ}\right.$ e $8^{\circ}$ séries $)$, ou seja, a adição de 50 minutos de aula, uma vez por semana, em cada sala de aula, dedicados à leitura exclusivamente. A princípio, as escolhas dos gêneros deveriam ser ecléticas - literatura popular de tradição oral, contos, crônicas, poemas, textos dramáticos, letras de músicas, charges, tiras e outros. A metodologia adotada prevê quatro tipos de leitura: leitura em voz alta, leitura programada, leitura expressiva, e, a principal e a única especificada, a leitura com ênfase. Essa última consiste em uma modalidade de organização didática, conhecida como Atividade Permanente; que funciona com o procedimento chamado de Leitura Compartilhada, utilizando-se de estratégias de leitura, que, segundo o projeto, quer dizer, seleção, antecipação, inferência e verificação, ou, em outras palavras, planejar o antes, o durante e o depois da leitura. Seriam contratados professores especialmente para a realização deste trabalho, para dinamizar o espaço da Hora da Leitura e desenvolver o gosto pela leitura.

Dois questionamentos podem ser feitos: há a necessidade de especialistas da leitura, uma vez que os professores em exercício possuem resistência para adotar uma metodologia já sugerida nos PCNs? O gosto é desenvolvido ou experimentado? Se considerarmos o gosto como uma ideologia aprendida socialmente, talvez. E se o entendermos, originalmente, como uma percepção do cérebro em relação a estímulos proveniente do exterior?

Superficialmente, o gosto pode ser interpretado como superestrutura, como manifestação de uma sociedade, categorizado pela pertença de grupos sociais. Um estudo mais profundo chegará aos elementos subjetivos e peculiares das escolhas individuais. Entre a massificação da primeira hipótese e o individualismo da segunda, 
há um preenchimento que é constantemente aflorado nas atividades humanas, sejam elas materiais ou simbólicas: a cultura, considerando-se a noção dada por Canclini (1984: 65): a produção de fenômenos que contribuem, mediante a representação ou reelaboração simbólica das estruturas materiais, para a compreensão, reprodução ou transformação do sistema social, ou seja, a cultura diz respeito a todas as práticas e instituições dedicadas à administração, renovação e reestruturação do sentido.

Para compreender um povo, há de se compreender a cultura, e esta está sob a compreensão de seu próprio tempo. Compreender o momento presente nos faz ver que a valorização e a legitimação de determinadas culturas, leituras, de determinados títulos de obras, é obviamente autoritária, e por muitas vezes, aleatória. Ela depende do tempo maior, histórico, e de outros tempos, inclusive o individual.

Como crítico, José Paulo Paes dedicou-se à pesquisa dos “injustiçados" (MEDINA, 1985). No primeiro capítulo de Pavão Parlenda Paraíso - uma tentativa de descrição crítica da poesia de Sosígenes Costa -, José Paes diz bem o que pensa em relações aos meios convencionais de consagração de um artista: “A vitalidade de uma literatura não se mede apenas pelo mérito daqueles autores que a crítica passou em julgamento e entronizou definitivamente como maiores. Mede-se também - e é forte a tentação de escrever sobretudo - pelo valor dos autores ditos menores que, negligenciados pelos contemporâneos, só tardiamente, o mais das vezes depois de mortos, conseguem se impor. É então que ocorrem as chamadas ressurreições literárias, atos de justiça tardia que, outra utilidade não tivessem, sempre serviriam para perturbar, com afloramentos sincrônicos, a digestão dos profissionais da diacronia" (Citado por MEDINA, 1985: 32).

Alberto Manguel, em Uma História da Leitura (1997: 125), manifesta sua compreensão em relação ao ditamento das valorações literárias e das leituras "permitidas" (a censura ocorre em outros tempos e outras maneiras que tão somente em 
regimes governamentais autoritários): "Leitores autoritários que impedem outros de aprender a ler, leitores fanáticos que decidem o que pode e o que não poder ser lido, leitores estóicos que se recusam a ler por prazer e exigem somente que se recontem fatos que julgam ser verdadeiros: todos eles tentam limitar os vastos e diversificados poderes do leitor. Mas os censores também podem adotar formas diferentes em seu trabalho, sem necessidade de fogueiras ou tribunais. Podem reinterpretar livros para torná-los úteis apenas a eles mesmos, para justificar seus direitos autocráticos. (...) Assim, nem todos os poderes do leitor são iluminados. $\mathrm{O}$ mesmo ato que poder dar vida ao texto, extrair suas revelações, multiplicar seus significados, espelhar nele o passado, o presente e as possibilidades do futuro pode também destruir ou tentar destruir a página viva. Todo leitor inventa leituras, o que não é a mesma coisa que mentir; mas todo leitor também pode mentir, declarando obstinadamente que o texto serve a uma doutrina, a uma lei arbitrária, a uma vantagem, particular, aos direitos dos donos de escravos ou à autoridade de tiranos".

Ao contrário da imposição da leitura, com os saraus de leitura, vê-se que os mediadores para estimulação de leitores, são, antes de mais nada, exímio e apaixonados leitores, como identifica Ana Machado “(...) imaginar que quem não lê pode fazer ler é tão absurdo quanto pensar que alguém que não sabe nadar pode se converter em instrutor de natação. Porém é isso que estamos fazendo" (MACHADO, 2001, p. 122). Quando na educação comportamental fala-se sobre a herança herdada não pela genética e sim do exemplo - que podem ser os pais ou, em muitas ocasiões, o professor -, estamos lidando com uma situação de relação entre indíviduos em contraposição à operação mecanicista da transmissão, quando afloram imaterialidades como a mágica da conquista, do encantamento, do auto-contágio voluntário: os enlaces invisíveis que nos unem na nossa condição exclusivamente humana por um breve momento tornam-se visíveis. O “apaixonamento" transparece e contagia, envolve os indivíduos, estejam eles 
na condição de texto ou na condição de leitura. O texto nada mais é do que indivíduos em diálogo, onde os interlocutores exercitam a liberdade de expressão e não o silêncio da aquiescência à interpretação unívoca. A leitura, ainda que silenciosa e individualizada, nunca será um ato solitário, pois o leitor não está inerte, ao contrário, participa de uma comunidade de leitores, onde as leituras são partilhadas com experiências vividas. É na troca de idéias que se constrói a pluralidade de significados. Riqueza de significados que não encontra força para ressurgir quando o professor valese somente das interpretações propostas pelo livro didático, não permitindo ao aluno ter outra interpretação. Tal proposta didática já não consegue estimular o aluno a ler e leva ao silêncio e à morte da crítica. Talvez por isso, os programas de incentivo à leitura devem alcançar a toda sociedade, inclusive os professores, e não apenas serem voltados aos alunos. É no compartilhamento pelo gosto pela leitura perceptível nos olhos e nos poros do leitor-mediador que desperta o leitor-ouvinte para transitar (e se descobrir) entre a leitura eferente (cognitiva) e a leitura estética (emotiva). Institucionalizada, a leitura não precisa resultar num trabalho avaliativo. Se o leitor-aluno ler e discutir o que leu, mesmo que seja para dizer que não gostou da obra e por que - pois isso são um posicionamento crítico e o exercício da liberdade -, o professor já obteve êxito. Pode-se buscar, por exemplo, a intertextualidade entre todas as formas de escritas e as variações da expressão humana, não apenas na diversidade de gêneros, mas também nas possibilidades de recursos, como os oferecidos pelas artes plásticas, teatral, pela televisão, cinema e internet.

Para educar é preciso ter antes de qualquer coisa a atenção e essa não se impõe se conquista pelo encantamento que pode ser construído, por exemplo, através de uma boa narrativa, no imensurável, no imprevisível. Educar é contar histórias. Como nos instiga Machado “[...] ninguém resiste à tentação de saber o que se esconde dentro de algo fechado - seja a sabedoria do bem e do mal no fruto proibido, seja na caixa de 
Pandora, seja o quarto do Barba Azul. Mas, para isso, é preciso saber que existe algo lá dentro. Se ninguém jamais comenta sobre as maravilhas encerradas, a possível abertura deixa de ser uma porta ou uma tampa e o possível tesouro fica sendo apenas um bloco compacto ou uma barreira intransponível” (MACHADO, 2001, p. 149). O professor como bom contador de histórias, pode ser esse desbravador que abre alternativas de caminhos sem ter imponência, e acima de tudo, torne-se alguém em que se espelhar. 


\section{Capítulo 7}

Da política pública ao público politizado

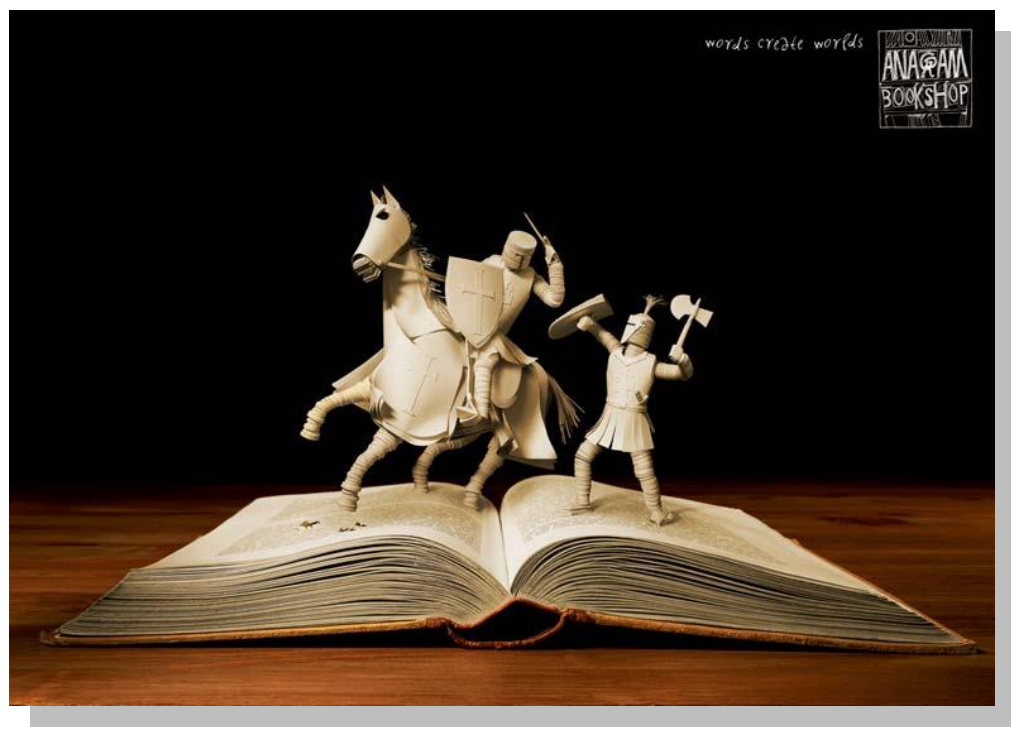

ESCOLA DE COMUNICAÇÕES E ARTES

Doutorado em Ciências da Comunicação

Teoria e Pesquisa em Comunicação

2010 


\title{
Capítulo 7
}

\section{Leitura}

\section{Da política pública ao público politizado}

\begin{abstract}
Não há possibilidade de êxito de políticas públicas de livro e leitura apenas com a implantação de bibliotecas e a distribuição de livros à população. A leitura como se deseja - social, transformadora - não está em códigos linguísticos e sim no texto que estreita relações humanas, que nos religa na condição de sermos humanos. Um programa de leitura precisa incluir a formação de pessoas que multipliquem o hábito da leitura, não pelo convencimento, mas pelo encantamento.
\end{abstract}

Fevereiro de 2005. A Secretaria de Cultura do Estado de São Paulo, por meio do programa São Paulo: Um Estado de Leitores veicula a campanha de lançamento do Ano Ibero-Americano do Livro e da Leitura, constituída basicamente de peças de outdoor (além de um filme produzido, mas não-veiculado, e cartazes), espalhados em 44 pontos da região metropolitana de São Paulo. Embora, em releases distribuídos para a imprensa, a Secretaria afirmasse que a campanha é direcionada exclusivamente aos jovens, a estratégia das localidades dos outdoors atinge um público-alvo diferente do almejado: os cidadãos que circulam na região centro-oeste, coração da cidade; a população paulistana economicamente ativa, jovem e adulta.

De óculos, cabelos presos em rabo de cavalo, e usando aparelhos ortodônticos, uma jovem mulher com ar sério, em primeiro plano e sem maquiagem, equilibra um livro em cima da cabeça, numa situação parecida com o treinamento de modelos para deixar o corpo e a cabeça eretos ao caminhar na passarela em desfiles. À sua direita, 
uma frase preenche o fundo branco e completa a peça do outdoor: Livro, coloque isso na cabeça. Embora a identificação daquela feição exija mais de oito segundos - tempo médio de leitura de um outdoor - para assimilação (DE FELIPPE, 1994: 37), percebe-se que a imagem é da cantora de músicas do estilo pop romântico e filha de um famoso cantor sertanejo: Wanessa Camargo. A demora do reconhecimento dá-se devido à transfiguração da imagem habitual de Wanessa, sempre presente em revistas, jornais, programas de televisão e nas colunas sociais como uma jovem sensual, despojada, descolada, independente e, até mesmo, como se autodenomina, libertina. $\mathrm{O}$ ato público mais polêmico da cantora foi entrevista dada à revista Veja, em 26 de fevereiro de 2003, em que anuncia publicamente, inclusive aos pais, a perda de sua virgindade

A escolha da cantora, para os organizadores da campanha, não foi aleatória. Nas palavras da então Secretária de Estado da Cultura, Claudia Costin:

Ter como aliada do projeto uma pessoa com a popularidade de Wanessa, dizendo que é apaixonada por leitura, aproxima-nos muito dessa meta. Oxalá um dia a leitura saia definitivamente dos limites das elites acadêmicas e ganhe a popularidade da música feita por Wanessa entre os nossos jovens.

Esta campanha faz parte do contexto do ano de 2005, escolhido como o Ano Ibero-americano da Leitura. A escolha foi em 2003, pelos Chefes de Estado de países da Europa e das Américas. A organização do Ano ficou sob responsabilidade da Organização dos Estados Ibero-americanos (OEI), em parceria com o Centro Regional de Fomento ao Livro na América Latina e Caribe (Cerlalc) e Unesco (United Nations Educational, Scientific and Cultural Organization). Programas de Governo, políticas pública de incentivo à leitura fundamentadas em campanhas de publicidade; o ano de 2005 foi uma ebulição do caldo imaginário coletivo com idéias associadas ao mundo da leitura. 
Este capítulo anatomizará este imaginário coletivo presente nas publicidades sobre a leitura. Ao falarmos de imaginário, usarei o sentido antropológico proposto por Gilbert Durand de semantismo das imagens, ou seja, um conjunto de imagens nãogratuitas que constituem o capital pensado e inconsciente do Homo sapiens articulado em duas vertentes: a arquetipal, das invariâncias, e a fenotípica, das imagens simbólicas das idéias e dos mitos (DURAND, 1997:18). Apesar de desenvolver certa crítica às ações de política pública referente à leitura, especialmente alguns clichês nas campanhas publicitárias, estou de acordo que são sempre válidos os esforços destinados a respaldar possibilidades, alternativas na sociedade e, neste caso em especial, despertar ou incentivar o interesse pela leitura. Ainda que alguns passos se dêem ao lado, em círculo e até mesmo para trás, pelos menos, estas questões ganham espaço, destaque e visibilidade na agenda social. Portanto, não é objetivo deste trabalho, criticar as políticas públicas enquanto ação política, embora exista uma decepção. Porém, essa decepção política é ponderada pelo cientista político Daniel Innerarity, em sua obra $A$ Transformação da Política (2002), no qual questiona se a origem deste desalento não se encontra justamente em nossa esperança demasiada. Segundo Innerarity, a política é uma atividade civilizadora, com possibilidades limitadas, que serve para mediar razoavelmente os conflitos sociais, longe de conseguir a harmonia plena e o consenso absoluto, muito menos ser a entidade salvadora para dar sentido à vida, garantindo a liberdade plena e o seu bom uso. Daí a política ser um aprendizado constante de decepção para aqueles que não dimensionam o fracasso e o êxito parcial - porque o absoluto não existe. Isso não quer dizer ausência de ideais. As atividades políticas são importantes justamente por que existem muitos ideais. A política democrática não questiona o valor desses ideais, apenas cria espaços em que estes possam ser debatidos de forma não violenta. O diálogo desrespeitoso pode gerar conflito, sendo a política, nos dizeres de Innerarity, o melhor meio para resolvê-los, se esta for praticada como 
compromisso, pacto e acordo, e não como um meio para obter objetivos parciais, de acordo com interesses individuais, de um determinado grupo ou do grupo do poder.

O autor também posiciona a política numa definição-desafio: fazer política é converter o disjuntivo em aditivo. A boa política é transformadora e sintetiza aquilo que é dicotômico por meio de uma relação de cooperação. Não é isto ou aquilo, mas isto e aquilo. Não se trata de preconizar o interesse de todos (o que é impossível), porém, não se pode deixar de tentá-lo.

Assim, à luz da obra de Innerarity, não se abordará aqui, um discurso ideológico sobre o "dever ser" político. Neste capítulo farei a ressalva de que, a todo gasto público deve-se uma cautela, como por exemplo, a humildade de reconhecer a existência de um buraco negro do que não se sabe sobre a leitura, inclusive cientificamente. Sem um melhor conhecimento de práticas da cultura brasileira, letrada ou iletrada, campanhas em prol da leitura que reforçam estereótipos em falência podem muito pouco. Ainda serão necessárias muitas pesquisas, principalmente de caráter qualitativo, bem fundamentado, em busca de uma história da leitura, que não se faz apenas de números estatísticas, absolutos -, mas se faz também deles. As pesquisas precisam ser planejadas de forma a contribuírem para um diagnóstico mais eficiente das condições do ato de ler no Brasil.

Incluí este capítulo ao montante deste trabalho, devido à movimentação social em torno da leitura causada pelo Vivaleitura, que me fez surgir uma questão, não resolvida nos parágrafos a seguir: o que vem a ser, afinal, política pública. Achava que uma definição me diria se o Vivaleitura foi de fato uma política pública de leitura, ou apenas uma propaganda de política pública de leitura. Mais precisamente, minha inquietude era compreender se o método usado no programa citado - sair à cata de projetos de leitura e colocar tudo dentro da mesma cesta legitimada pela assinatura do Governo Federal - tinha aliciado aos projetos já vigentes, apoio de recursos, incentivos, 
sistematizações, coordenações e organização, e não ficado apenas na promoção de uma campanha de programa de governo. Em outras palavras, minha inquietude era compreender se a estratégia do Vivaleitura é legítima, ou, como diz o ditado popular, foi apenas cortesia com o chapéu alheio.

Fui à pesquisa. O caminho traçado começava pela indagação de quem, qual campo de estudo, tinha o know how para definir o que é política pública. Entre algumas tentativas de definição na Ciência Política, encontrei uma aparentemente didática:

Para os efeitos desta biblioteca, política pública - equivalente, em português, da expressão inglesa policy - é um conjunto de ações ou normas de iniciativa governamental, visando determinados objetivos. Nesta perspectiva, política pública tem sempre caráter estatal, ainda que sua execução através de programas, projetos e atividades possa envolver agentes privados. De acordo com nossa convenção, portanto, uma ONG não formula nem emite política pública. O que não a impede de apresentar propostas de políticas públicas a diferentes níveis (federal, estadual ou municipal) ou poderes (executivo, legislativo e judiciário) de governo, criticar ou apoiar esta ou aquela política pública, ou até mesmo assumir funções típicas de agências governamentais na execução de uma política ou programa. Agências multilaterais e governos estrangeiros também formulam propostas de ação governamental para determinados países, as quais só se convertem concretamente em política pública efetiva quando os governos desses países as adotam. Atores externos às vezes são extremamente importantes na formulação das políticas públicas de um país. Para os nossos efeitos, políticas públicas correspondem ao conjunto das normas, regulamentos, decisões, ações políticas e estratégias estabelecidas para fomentar o desenvolvimento de programas, projetos e atividades de desenvolvimento para determinada área social, bem como os recursos alocados para tal finalidade. (Texto extraído de artigos do Projeto Bibliotecas Virtuais Temáticas da Unicamp) 
Tal concepção vai ao encontro de outras definições também da Ciência Política, que vê a política pública como uma ação do Estado sobre a sociedade, portanto com um caráter imperativo, em que o Governo é responsável por decisões revestidas da autoridade do poder público. Para a definição do Vivaleitura, não me satisfiz, porque ainda que esta explicação dê abertura para que a execução dos programas aconteça em outras esferas que não somente a estatal, o contrário, a entidade estatal tomar para si os programas que já acontecem, não é considerado.

Na Educação, o enfoque não é tanto nas iniciativas estatais, ao contrário, há uma visão de que as políticas públicas não são meras decisões políticas, uma vez que formulá-las implica em coordenar ações de forma a desenvolver uma estratégia política. Ou seja, há uma corrente de pensamento que entendem políticas públicas como uma comunhão de ações coletivas voltadas para a garantia dos direitos sociais, configurando um compromisso público que visa dar conta de determinada [ação], em diversas áreas. [A política pública] Expressa a transformação daquilo que é do âmbito privado em ações coletivas no espaço público (GUARESCH, 2004:180). Transpor ações do espaço privado para o público justificaria o Vivaleitura, se esta mudança não tivesse se limitado apenas à troca de endereço, assinatura e rótulo, e não transmitisse às identidades públicas e ao Governo as responsabilidades de torná-las ações coletivas organizadas, sistematizadas, apoiadas com iniciativas, leis, recursos e verbas.

Ambas as definições, a meu ver, não categorizariam o Vivaleitura, que agregou em documentos (publicações e sites) cem mil ações contabilizadas no fechamento do Ano Ibero-americano do Livro e da Leitura. Porém, a quase totalidade destas ações já estava em execução pelos setores privados e por organizações não-governamentais, e nada a elas foi acrescentado. É bem verdade que algumas mobilizações, especialmente no legislativo, referentes às questões tributárias sob o livro, foram - como não poderia ser diferente - de fato, uma iniciativa governamental. No final de 2004 , o Governo 
Federal editou medida provisória que isentava as editoras de livros que apuram resultado pelo lucro real do pagamento da alíquota de 9,25\% do PIS-COFINS-PASEP, a que estavam sujeitas desde 2003. Outras medidas foram tomadas para para desonerar todos os impostos da cadeia produtiva do livro. Em contrapartida, os grandes editores contribuíem com $1 \%$ do seu faturamento bruto para a criação do Fundo Nacional do Livro. Como podemos perceber, no caso da tributação, política pública e política de mercado se mesclam. Mesmo assim, tais iniciativas devem ser vistas com cuidado. Segundo pesquisa do professor Francisco Anuatti Neto, da Faculdade de Economia, Administração e Contabilidade de Ribeirão Preto, a desoneração impactou apenas os custos das grandes empresas - editoras e livrarias usaram-na para recomporem as margens de ganho -, mas as medidas não se materializaram na redução final dos preços, não alcançou os consumidores. A pesquisa tabulou os preços de títulos em catálogos, e mostrou que o preço médio de 88,9 mil títulos em dezembro de 2004 , antes da desoneração, era de $\mathrm{R} \$$ 34,10. Em dezembro de 2005 esses mesmos títulos alcançaram um preço médio de $\mathrm{R} \$ 35,40$, um aumento de 3,76\%. Em 2005, o reajuste médio foi 4,3\%, e alguns títulos chegaram a ficar até $8 \%$ mais caros. A conclusão dos dados numéricos do mercado mostra que lucros maiores não dependerão somente de desonerações, mas de aumento de vendas também, ou seja, do número de leitores e de leituras. Neste sentido, o crescimento das vendas de livros depende também de políticas de estímulo ao hábito de leitura.

Talvez à luz do Direito, como ciência reguladora das relações sociais, encontraria uma noção mais satisfatória. O comentário da jurista Maria Paula Dallari (BUCCI, 2002), que me pareceu mais sensato, diz estarmos bem longe da fixação de um sentido preciso e de aceitação geral em relação ao conceito de políticas públicas. A única afirmação possível seria dizer que esta está ligada às interferências do Estado na vida social para a consecução de objetivos e interesses comuns. Porém, neste sentido, 
política pública não difere muito daquilo o que é essencialmente o dever da política, sem adjetivações.

Esta busca de conceitos originários é importante para discernir e identificar velhas ações e dizeres, com roupagem sob o título de novos e de mudança. Juntar tudo no país ligado, de alguma forma, à leitura e dar a isso uma assinatura do Governo e um nome de política pública, sem um documento de compromisso, de princípios, sem uma sistematização, orientação, inclusive de verbas e aprimoramentos, torna este tipo de ação passível de questionamentos. Como também é questionável, a idéia de que o Vivaleitura é a primeira iniciativa pública neste campo - o Plano Nacional do Livro e Leitura (PNLL), o primeiro da história do Brasil, surgiu como consequência direta da forte mobilização que se verificou em 2005 no Brasil [...]-, e que como iniciativa de política pública este não estaria, como atribuiu o coordenador da mesa no fechamento do Ano Ibero-americano e lançamento do Plano Nacional do Livro e da Leitura, Galeno Amorim, à mercê do partido do poder e das prioridades de gestores. Política pública está necessariamente vinculada aos objetivos de um determinado programa de governo. Muda-se o partido, mudam-se as cabeças, mudam-se os programas sociais, muda-se o foco, como veremos mais a seguir numa rápida comparação do Vivaleitura ao Programa Nacional de Alfabetização e Cidadania.

Embora o campo de pesquisa escolhido aborde as ações de política pública de incentivo à leitura durante o Governo representado pelo presidente Luiz Inácio Lula da Silva, vale fazer uma rápida retrospectiva, a fim de se esclarecer que este não é o ponto inaugural, até a medida fundadora de políticas públicas direcionadas à leitura. Todas as medidas no âmbito da Educação, até mesmo quando o país não era Brasil (o projeto Memória da Leitura da Unicamp possui iconografias do século 16 e documentos escritos do século 18), envolvem, em seu bojo, a leitura. Um recorte possível, a título de exemplificação, seria o período em que, depois de anos de ditadura, conquistamos a 
prática do direito de voto por eleições diretas, quando reanimam-se as forças na consolidação da democracia brasileira. Em 11 de setembro de 1990, a questão da leitura era tratada no entorno da declaração do Ano Internacional da Alfabetização, que no Brasil resultou no Programa Nacional de Alfabetização e Cidadania. Em discurso do então presidente da República Fernando Collor e Mello ficaram registrados as intenções do programa (trechos):

Criar condições para um ensino básico moderno e para banir de uma vez por todas de nosso dia-a-dia a vergonha do analfabetismo. [...] Não pode ir para adiante um país em que vinte por cento da população com mais de quinze anos de idade não sabe ler e escrever, em que quarenta milhões têm menos de quatro anos de escolarização. De cada cem crianças que ingressa na escola primária, apenas vinte e duas logram [...] As tarefas primordiais que temos hoje consistem na erradicação do analfabetismo e na universalização do ensino fundamental. O país que não investe nessas duas frentes arrisca-se a ver inevitavelmente comprometidos todos os seus esforços de desenvolvimento, pois é o capital humano que assegura a mobilização das potencialidades de uma nação. [...] Lançamos agora uma estratégia que rejeita a cultura das dádivas do estado e obedece à idéia democrática de que quem muda a nação não é o governo, mas sim o povo. [...] Até o final do governo, é nossa meta reduzir em setenta por cento o contigente de analfabetos do país. Daremos assim um grande passo para o cumprimento da previsão constitucional de acabar com o analfabetismo e de universalizar o ensino fundamental até 1998. Precisamos atacar o problema social da educação no Brasil, que é o problema do ensino básico. Proporcionar um mínimo de oito anos de escolaridade aos nossos jovens constitui hoje um imperativo de sobrevivência social $e$ econômica da nação. [...] No momento em que a democracia se generaliza como modelo político, em que a paz se afirma como regra de convivência entre os povos, em que o respeito ao meio ambiente se consagra como parâmetro do desenvolvimento, e em que a capacitação científica e tecnológica se destaca como fator determinante do progresso, a educação passa a ser uma base cada vez mais indispensável ao surgimento e à consolidação de sociedades politicamente livres, economicamente avançadas e socialmente justas.

Os princípios deste programa de 1990 eram: responsabilidade solidária com a participação da sociedade civil organizada e compromisso assumido do Estado; 
responsabilidade financeira, com ampliação de recursos e redistribuição criteriosa; fortalecimento da instituição escolar por sua condição permanente e estável de oferta da educação básica; e medidas de valorização do professor. Em 2005, 15 anos depois, o Vivaleitura define quatro eixos estratégicos principais: democratizar o acesso ao livro; investir em formação e processos que fomentem a leitura; trabalhar o livro no imaginário coletivo e, nesse sentido, cabe ao governo criar campanhas de estímulo à leitura; apoiar a indústria do livro, aos escritores e ao financiamento de editores; e a abertura de novas livrarias.

É notório que neste último, há uma mudança de foco que vê a leitura separada de uma questão maior sobre a Educação. Claramente, os objetivos estão direcionados ao suporte-livro, uma das associações mais comuns do imaginário coletivo, em relação à leitura. E assim também foi muitos dos projetos do Plano Nacional do Livro e Leitura, realizados com base na doação e distribuição de grandes quantidades de títulos. Livro na cesta básica, mini-bibliotecas itinerantes chamadas de Arca das Letras, são exemplos de ações que traduzem o conceito de democratização do livro dentro desta ação de política pública: colocar um livro na mão de cada brasileiro. A conquista de um leitor passa pela posse de um livro?

Esta idéia de "democratização do livro" é coerente com um paradigma vigente de difusão ou divulgação. Uma análise minuciosa mostra esse paradigma como encobertador de um caráter autoritário. Cremilda Medina em seu projeto Signo das Relações (disponível em http://www.ccs.usp.br/imprensa/signo.pdf) propõe que há uma distância histórica entre o paradigma da divulgação e um conceito de relação, de dialogia social. O primeiro tem na técnica e na tecnologia suas mediações facilitadoras, enquanto que no segundo, a mediação acontece na habilidade profissional, autoral, artística e humana presentes no papel mediador de agentes culturais, na capacidade cultural da produção simbólica que revaloriza a cadeia de poderes e atribui outros 
sentidos que não os sedimentados, e assim, nos fazem capazes de interferir no mundo material, no mundo natural e no mundo humano. O primeiro enfatiza os meios como mediação, o segundo, o ser humano como mediador.

O signo dialógico das mediações sociais envolve a desconstrução do autoritarismo unidirecional - fonte de informação dita científica, técnicos de "tradução" $e$ receptor anônimo, massificado. (MEDINA, 2000: 7)

Ainda que a falta de acessibilidade ao livro, até mesmo por seu preço de compra, seja de fato um problema social, democratizar a leitura distribuindo livros é uma visão difusionista. Se fizermos o exercício de inverter os vetores - das vozes legitimadas, para as abafadas -, e mais que inverter, de conscientizarmos que a cultura acontece nas práticas do dia-a-dia, nos significados que passam por uma peça de fluxo e refluxo, dando a circularidade do processo, encontraremos uma compreensão de que o livro em si é meramente suporte. A leitura está mais intimamente ligada aos sujeitos que aos suportes. A questão da leitura vai muito além do suporte - livro ou código verbal. Ela nasce da cultura, dos nexos, vínculos (e não amarrações, pois continuaria sendo um ato autoritário), das conexões dos sujeitos com a leitura e da leitura com os sujeitos, e é deste ato relacional e dialógico que afloram significados da leitura de acordo com as demandas coletivas, e também das demandas individuais, pois as leituras de um grupo ou de um indivíduo revelam o ponto de vista, como estes vêem e estão no mundo. Além de elemento fundamental na constituição dos sentidos, o leitor pode ser considerado também em seu aspecto coletivo, ou seja, enquanto comunidade de leitores que compartilham certas maneiras de ler. Escolher o livro como ícone de leitura pode não estar coerente com as demandas atuais de leitura. Por exemplo, onde e como se contabiliza as leituras em meios eletrônicos? 
A escolha de campanhas pressupõe a publicidade além de uma atividade econômica, como uma produção simbólica impregnada de valores, comportamentos e estilos, que movimenta o imaginário da cultura social. Como método, a publicidade manifesta-se utilizando quase todas as linguagens existentes em nossa sociedade escrita, cores e formas, a fotografia, o cinema, a pintura, o desenho, a literatura, a oratura, a música, os sons, a escultura, a dança, etc. - afinal ela prima pela visibilidade, estetização, agradabilidade e, principalmente, do consumo de bens simbólicos. Por isso mesmo, as linguagens atuais, por mais anti-capitalistas que se auto-declarem, absorvem suas técnicas e lógica, pois estas, também produzem bens simbólicos e querem vê-los consumidos. Para se tornar mais efetiva a publicidade pode combinar diferentes formas de expressão artísticas e distintas formas de narrativas sociais. No universo da publicidade podemos encontrar etnias, gírias, ilustrações, vestuários, padrões estéticos, gastronomia, enfim, produções simbólicas inseridas na cultura de determinada sociedade. Mais do que a visão academicista, são as imagens de leitura originadas em espaços não-acadêmicos, formadas por idéias do senso comum sobre leitura, que circularam com facilidade, na mídia de uma forma geral, e, especificamente, na publicidade. Essas idéias, embora sem o status normativo das idéias vindas do circuito acadêmico, também fazem parte do imaginário coletivo. Assim, pode-se afirmar que a publicidade participa ativamente do processo de construção do saber de leitura.

A publicidade, ao contrário da estática proposta pela corrente do conceito de comunicação de massa em que esta possui um propósito unilateral de estar a serviço dos poderes hegemônicos, é constituída de características provenientes do seu papel de mediadora social intrínseca à sua natureza de comunicação social. Como ciência, lembra Morin (1995:260), a publicidade, para se tornar mais eficaz, precisa se basear cada vez mais em conhecimentos científicos; porém como sistema cultural requer maior 
atenção da sociologia, a fim de compreender seu modo de funcionamento, sua inserção e função na vida social. Diz o autor:

A publicidade não é apenas mais um elemento nos sistemas de produção, distribuição e consumo [...]. A publicidade, como mediadora de consumo, estende seu campo de ação a todos os horizontes e inunda, literalmente, a vida social.

Além de agregar distintas formas de expressão da identidade social, a publicidade é um termômetro social e uma manifestação do imaginário coletivo elementos vindos do cliente (o que ele acha sobre seus consumidores), de pesquisa de mercado (aquele perfil de consumidor criado em forma de compósito), daquilo que o consumidor pensa sobre si mesmo (ligado mais ao perfil psicológico do que ao poder aquisitivo, econômico), e aqueles nascidos no ato de criação, pelas mãos e cabeça dos mediadores, os publicitários.

Projeções: esta é a matéria-prima da publicidade que de maneira nenhuma é composta de verdades absolutas. Todas as projeções são fruto de um processo complexo, que envolve diversos agentes, e se baseiam (deveriam se basear) em pesquisas de mercado, com as empresas, os concorrentes, o comprador, o consumidor, os consumidores potenciais, em testes de projetos, em planejamentos de campanha. Também não significa que esta foi feita para propagar uma mentira no mercado de consumo. Embora os argumentos utilizados e a mentira estejam separados por uma linha tênue de ética e princípios profissionais, a publicitária, em sua essência, intui criar mecanismos persuasivos - com estratégias emotiva e lógico racional - que estimulam o consumidor a obter o bem anunciado. Para isso não se explora nem a veracidade nem a falsidade da informação, mas o bem-estar do consumidor diante do consumo de determinado bem - produto ou serviço. 
Diante destas prerrogativas, podemos repensar algumas das campanhas produzidas em 2005 para incentivo da leitura. Todo planejamento de marketing inicia-se no aprofundamento do conhecimento do produto, do que se quer falar, da idéia de que se quer vender, portanto, o primeiro exercício é identificar o produto destas campanhas. A pergunta é: o produto seria a leitura? As campanhas do Vivaleitura vendem o livro, e se querem vender a leitura, estão sempre vinculadas ao livro. Associar a leitura ao livro é o imaginário arquétipo mais aceito, o de maior força social desde o século 19, quando a literatura passou a ter a função clara de disseminar a noção de nacionalidade. Optouse, assim, uma narrativa de lugar-comum para a campanha, apesar de a publicidade como um processo de mediação social de valores simbólicos, possibilite, através dos agentes culturais, que se recriem novas narrativas que dialoguem com a realidade social e nela introduzindo novos elementos de identidade cultural, resignificados. A campanha torna-se ainda mais estereotipada ao transfigurar a imagem despojada de Wanessa Camargo para um fake (inverossímil) estigmatizado da jovem intelectual. Perdeu-se a oportunidade.

Século 21, passados dois séculos, as mudanças no comportamento da sociedade atingiram o hábito de leitura e o modo de leitura. Os antigos e teorias de leitura não têm sido suficientes para compreender os fenômenos contemporâneos, pois ler é, acima de tudo, uma tarefa comprometida com seu tempo. Isso afeta a maneira com que entendemos a leitura. Com a propagação da eletrônica e dos dados virtuais, a linguagem verbal escrita em papel não dá conta, por si só, do emaranhado de produções culturais que permeiam o nosso dia-a-dia. Sem contar que apenas em situações especiais pode-se falar hoje em leitura apenas do verbal, já que muitos textos articulam diferentes linguagens.

Além de associarem a leitura somente ao livro, as campanhas a tratam numa esfera demasiadamente conceitual. Livro, coloque isso na cabeça e uma foto em que 
livros estão sobre a cabeça da modelo, faz destes um elemento da composição do cenário da fotografia, o que é um fato recorrente também na mídia, que colocam o livro junto a uma personalidade para compor uma imagem de luxo, de chique. Mas nestes casos, o livro é objeto de enfeite e não para uso. Os livros compõem a cena. O objeto e a ação, o livro e a leitura são confundidos como produto. Como foi exposto acima, a publicidade ganhou espaço social, não por dizer a verdade, ou a mentira, mas por oferecer bens que contribuam para o bem-estar de quem adquire estes bens. Assim, passada a fase fordista, em que a ênfase era o produto, a publicada trabalho hoje com o foco no consumidor em ação, consumindo o bem. A identificação acontece não pelo produto, mas pelo ideal de consumo. Nenhuma campanha publicitária vende uma porcentagem de tabaco misturado com alcatrão, mas a atitude de fumar; ou se este exemplo for politicamente incorreto, ninguém vende lauril éter sulfato de sódio, com cloreto de sódio, formaldeídos, extratos e água deionizada, e sim um xampu para cabelos normais que deixam seus cabelos mais sedosos. Se houvesse a conscientização que a leitura é feita não do livro, mas sim do texto que se transforma dentro de nós, não se investiria tanto na importância da leitura como conceito.

Tendo a leitura como ação, outra pergunta referente à pesquisa de mercado seria pungente: para que fim se presta a leitura? Em uma retrospectiva histórica podemos encontrar diversas formas de instrumentalização da leitura: Lutero defende no século 15 a leitura como ato de libertação da dominação da Igreja, ler para saber os verdadeiros ensinamentos da Bíblia; no século 18 a leitura ganha status de instrumento de libertação do absolutismo, ler para não ser analfabeto; com o desenvolvimento do capitalismo, a leitura passa a ter valor de mercado; entre o professor e o aluno estabelece-se um trato de leitura objetivada, ler para responder um questionário, ler para passar de ano; numa visão mais individualista, a leitura é um elemento para se diferenciar das outras pessoas, que, na idéia de competição de profissionais, se traduz em atualização, garantia o 
emprego, e assim por diante. Só nestes exemplos percebe-se como a leitura é reflexo e refração da cultura de um grupo. Porém, como os saraus de leitura que tive a oportunidade de realizar me mostraram, reduzir a leitura a uma possibilidade, ou algumas, é acreditar numa leitura idealizada. A leitura possui uma característica intimista que não garante nada para fora do indivíduo, e sim para dentro. Nem mesmo a leitura pelo prazer pode torna-se regra. A leitura vai sempre além. Os prazeres da leitura são múltiplos (MORAIS, 1996). Lemos para saber, para compreender, para refletir. Lemos para compartilhar. Lemos para sonhar e para aprender a sonhar. Lemos pela beleza da linguagem, para nossa emoção, para nossa perturbação. Ler é também esquecer. Morais lembra que na literatura filosófica a leitura foi muitas vezes comparada à alimentação. O texto é lido conforme nossa fome e nossa disposição momentânea, a gente engole, devora, mastiga, saboreia. Roland Barthes registrou em $O$ prazer do texto (1975) que "ler é pastar". O mesmo autor, em Crítica e Verdade (1987), sugere que esse prazer do texto está em desejar a obra, é pretender ser a obra. Já para o autor do texto, o prazer é pode prever a leitura que cada pessoa fará do que ele escreveu. Para Nietzche, "ler é digerir". Por vezes vemos a leitura ser tratada como uma ação vital: Ler é respirar. Daniel Pennac escreve O homem (...) lê porque sabe que está só, e explica, por estar só, o verdadeiro prazer de um romance reside na descoberta dessa intimidade paradoxal: o autor e eu. A pluralidade destes imaginários não se mostraram presentes na campanha.

A idéia recorrente na mídia é a ausência de leitura no Brasil. A leitura é vista como uma atividade cultural que os brasileiros não apreciam ou não praticam com assiduidade. Na visão daqueles que acreditam nesta imagem, os brasileiros é um povo inculto que não cultiva atividades de reflexão como a leitura, preferindo a televisão, o cinema e outras mídias visuais, tidas como leituras mais fáceis. É bom notar um dado interessante sobre essa imagem. Quando se mencionam os brasileiros como não- 
leitores, citam-se normalmente as estatísticas de vendas de livros ou periódicos no país, e esta estatística é proveniente apenas dos números de venda per capita. Há uma falha nestes dados, pois não conseguem mensurar os movimentos de circulação de um mesmo impresso e o número de leitores que irão lê-lo. Por desconsiderar as leituras realizadas por pessoas que, talvez, não tenham adquirido os livros que lêem, tais índices não podem ser entendido como representativo das práticas efetivas de leitura no país. Além disso, não são contadas, também, as várias leituras efetuadas num mesmo material de leitura (leituras em bibliotecas, em salas de esperas, empréstimos pessoais). Assim, não obstante sua fragilidade, essas estatísticas são frequentemente apresentadas na mídia e acabam por fortalecer a imagem do brasileiro não-leitor, tanto na imprensa diária quanto em semanários. E são estas imagens que ganharam espaço, e mais força, na publicidade no ano ibero-americano do livro e da leitura.

Mas em que grupo esta imagem se materializa? Quem são os não leitores do Brasil? Identificar o público-alvo é outro ponto fundamental para o planejamento de uma campanha publicitária. Em qual pesquisa se fundamentou a campanha de incentivo à leitura para que houvesse a definição de que o público-alvo da campanha protagonizada pela cantora Wanessa Camargo seria os jovens. São os jovens os nãoleitores. É nos jovens que está o problema da leitura, ou neles está a solução? Além dos compradores, o que sabemos sobre o público consumidor de livros? Quem são leitores? Que livros lêem? Qual é o perfil destes leitores? Como são suas práticas de leitura? Sem saber quem são e como são os consumidores, individualizando as práticas de leitura, uma campanha em pouco poderá surtir efeito. Idealizar um modelo de leitor ou de nãoleitor é um equívoco. Não lemos um mesmo texto da mesma maneira. Não lemos todos os mesmos livros, e se lêssemos, não faríamos a mesma leitura, não o leríamos do mesmo jeito. Há leituras respeitosas, analíticas, leituras para ouvir as palavras e as frases, leituras para reescrever, imaginar, sonhar, leituras narcisistas em que se procura a 
si mesmo, leituras mágicas em que seres e sentimentos inesperados se materializam e saltam diante do leitor. A liberdade é indispensável para a experiência da leitura. O prazer de ler ignora os preceitos de normalidade regrada pelos que já sabem: os adultos, os professores, os críticos de literatura. Leitura é um ato de interação entre o autor, o texto, o momento e o leitor, um ato de comunhão, que não é específica da leitura, mas compartilhada com todas as formas da arte.

Se fosse feito um recall, outra prática de publicidade para sentir o efeito da criação publicitária, poucas pessoas se lembrariam da mensagem da campanha de lançamento, pois esta ficou apenas cinco dias em cartaz - os espaços dos outdoors, cedidos por empresas do ramo, foram trocados por campanhas pagas.

Numa estação de rádio, um locutor em off informa que o ator está envolvido com a máfia e não resistiu aos grandes chefões, Gianecchini se meteu em intrigas, sofreu ameaças. Na versão imagética, o foco da filmagem se abre e mostra Gianecchini com o livro "A Máfia" aberto em sua mãos. Em seguida, uma narrativa fala sobre Cleo Pires. A mesma voz anuncia que ela ameaça largar tudo e ir para um convento, Cleo Pires entrou para a rotina de um convento. Lá encontrou o ambiente ideal para refletir sobre sua vida. As orações, o voto de castidade. Tudo tão perfeito que a atriz agradece a Deus por encontrar um livro tão bom. A atriz tem em suas mãos o livro "O Convento". Gianecchini e Cleo Pires dão o desfecho do filme e culminam com a frase, Esse é o poder da leitura. Faz a gente viajar e viver aventuras incríveis. No segundo semestre, outra campanha foi lançada, com outra tentativa de abordagem sobre a leitura. Abolido o mote Livro coloque isso na cabeça, foi lançado outra campanha em outubro de 2005 com o mote Ler é gostoso. Tem que ler. Protagonizada pelos atores globais Reynaldo Gianecchini e Cleo Pires, o planejamento de mídia da campanha focou os veículos rádio e TV. 
As campanhas mostram uma dialética muito recorrente: a leitura como prazer e a leitura como obrigação. Apesar de o foco dar um ensejo de leitura por prazer no slogan Ler é gostoso, reforçam a idéia da leitura-obrigação com o complemento Tem que ler, como na campanha anterior, evidente na frase coloque isso na cabeça. Em Wanessa, o livro deve ser posto na cabeça, em Gianecchini e Cleo, o argumento usado para a leitura é mais imperativo: tem que ler.

Poderíamos pensar que estamos caminhando certo, uma vez que as campanhas publicitárias e projetos do ano do livro e da leitura resgatam a idéia Ler é prazer. Realmente, a leitura só se perpetua incondicionalmente, se o leitor encontrar prazer neste ato. Um prazer alimentado não de verdades - das leituras corretas, mas de experiências insólitas e de imaginação. Porém como se ensina aos indivíduos que a leitura é prazerosa? Como fazer com que a atividade de leitura entre no espaço simbólico de lazer dos cidadãos concorrendo com o a televisão, a prática de esportes, um passeio no parque? Estas atividades são concorrentes?

De qualquer forma, a imagem que associa leitura ao prazer tem grande circularidade, e geralmente é acompanhada da idéia de leitura como vivência de experiências imaginárias, diferentes da realidade, do cotidiano do leitor. Normalmente veiculada em propagandas de livros ficcionais ou mesmo em campanhas para a leitura de livros infanto-juvenis, a leitura é vista como uma forma de escape da realidade para mundos fantasiosos onde o leitor pode viver situações diferentes do mundo real. A leitura como entretenimento aparece com frequência em catálogos de editoras ou mesmo em feiras de livros e chega a relacionar leitura como uma forma de prazer paralela a outras mídias como a televisão ou o cinema, com a grande vantagem de despertar a criatividade do leitor. A presença dessas imagens de leitura na mídia faz com que se assimile este discurso, o tom da campanha do Vivaleitura. A noção de leitura escolhida diz que a boa leitura seria sempre aquela que pudesse dar prazer ao seu 
leitor e levá-lo a mundos desconhecidos ou fantasiosos. Leituras sem prazer e sem fantasia afastariam o leitor dos textos, como se todos eles devessem, necessariamente, patrocinar esses elementos. Ler seria uma questão apenas de deleite, o que enfraqueceria a importância de inúmeros textos que parecem representar desprazer, enfado e mesmo tédio - geralmente as leituras da escola, indicadas pelo professor. De fato esta é uma associação importante, mas, tida como única, é uma perspectiva bastante reduzida da leitura.

Enquanto a leitura não se tornar prática - e ser vendida como tal -, provavelmente também não se desenvolverão habilidades de leituras, não se aumentarão os números de leitores. Não se ensina o que é prazer. Apenas se mostra o caminho e se estimula a caminhar. A descoberta é totalmente individual e intimista. Só dizer que a leitura é uma forma simples e mágica de prazer corre-se o risco de estar propagando uma demanda falsa, veiculando uma propaganda enganosa. Vender o prazer fácil da leitura é tão falacioso quanto associar a leitura ao ócio, à alienação e à chatice. A leitura pode ser tudo isso, mas sempre será mais um pouco disso. Ler, muitas vezes, se revela um trabalho árduo, doloroso, que exige disciplina, esforço, concentração, mas isso não lhe tira a porção que movimenta o leitor para frente, que o mobiliza, que o conquista. Há leitura legitimadas, leituras fadadas ao obscurantismo, leituras subversivas. Existem pais que não gostam que seus filhos desperdicem tempo lendo fora dos estudos; a leitura no espaço de trabalho, por vezes é tida pelos chefes como ócio; professores que repreendem alunos por estarem com gibis escondidos debaixo da carteira. Há pensamentos, que apesar de serem tidos como ultrapassados, ainda resistem no imaginário das pessoas. Ainda há uma tendência a acreditar nos efeitos perniciosos da leitura, que a leitura tem o poder de fazer perder o juízo, que, como se acreditava em outros séculos, pode de levar os românticos ao suicídio, ou ainda, que ler não é um comportamento afeminado. 
Embora existam todas estas narrativas estereotipadas, pode-se observar que o imaginário de leitura que circula atualmente é bastante positivo, evidenciando que a leitura é considerada uma prática de grande valor social, vista como meio de capacitação, aprimoramento e transformação do leitor, sobretudo por ser meio de acesso à informação e atualização. No entanto, dizer que tais imagens, ao sublinharem a importância da informação, apagam o fato de que o acesso a ela não mais se dá exclusivamente através de fontes escritas ou impressas. E, se a leitura já possui este destaque e valorização social, podem-se economizar esforços e recursos a fim de dizer isso à sociedade.

Fevereiro de 2006. Um ano depois da campanha de lançamento, a protagonista Wanessa Camargo participa de uma nova versão, totalmente oposta à primeira, com maquiagem carregada, cabelo esvoaçante e cara de símbolo sexual. Os livros continuam na cabeça, mas a posição de sua cabeça não sustenta o peso dos livros, numa clara montagem feita em programa de imagem. Será que é forçando uma identificação, na artificialidade, que as campanhas tocarão a sensibilidade para estimular a leitura? Quanto mais a leitura for tratada apenas na esfera da conceituação e da idealização, mais afastada ela ficará da prática. 
Janeiro de 2005

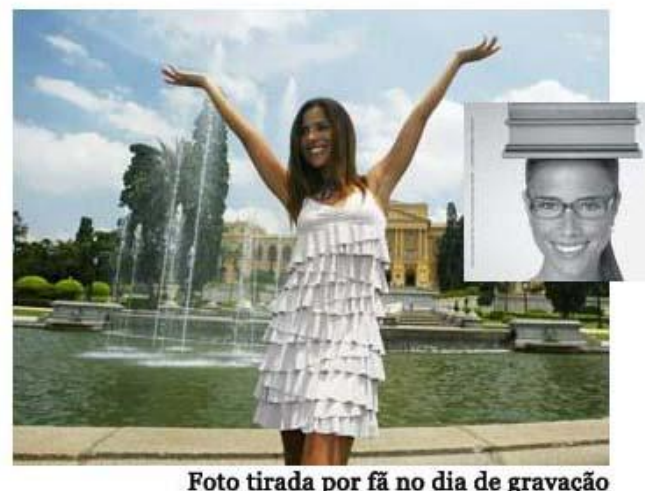

da campanha para TV.
Fevereiro de 2006

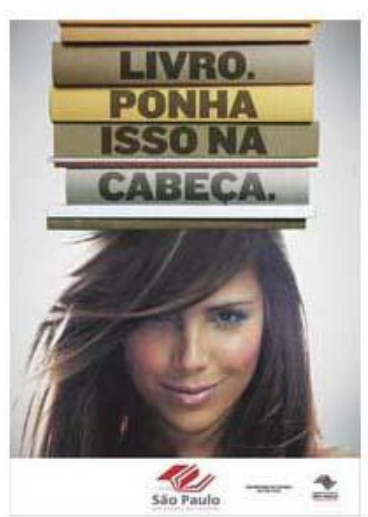

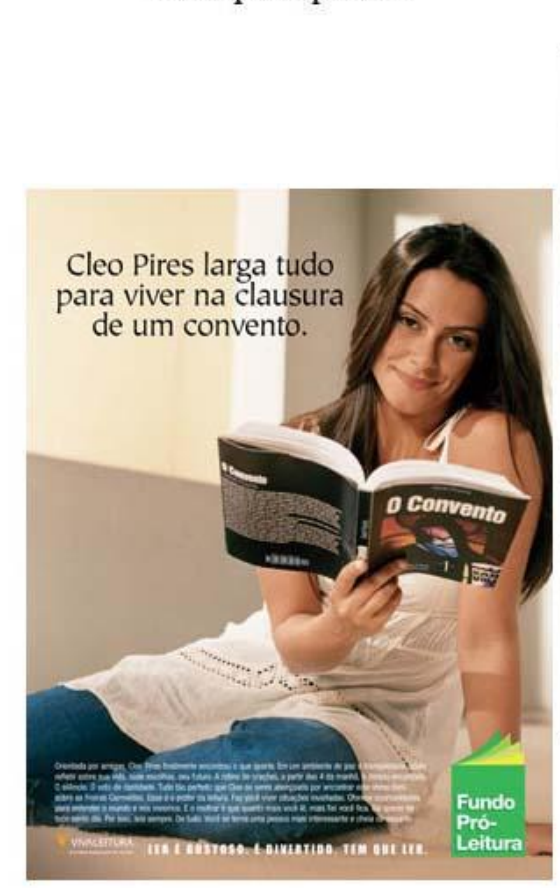

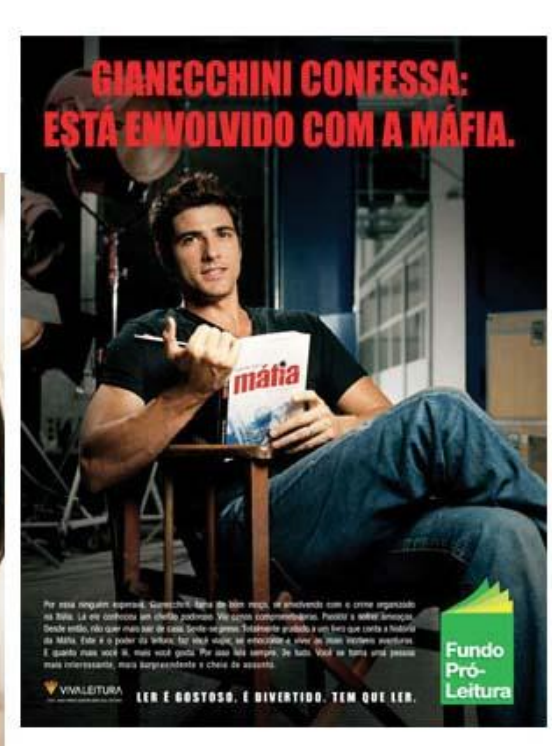

\section{LIVRO. \\ PONHA ISSO \\ NA CABEÇA.}

- $\ldots$ N in 


\section{Capítulo 8}

Signo da Relação: a Construção Social dos Sentidos

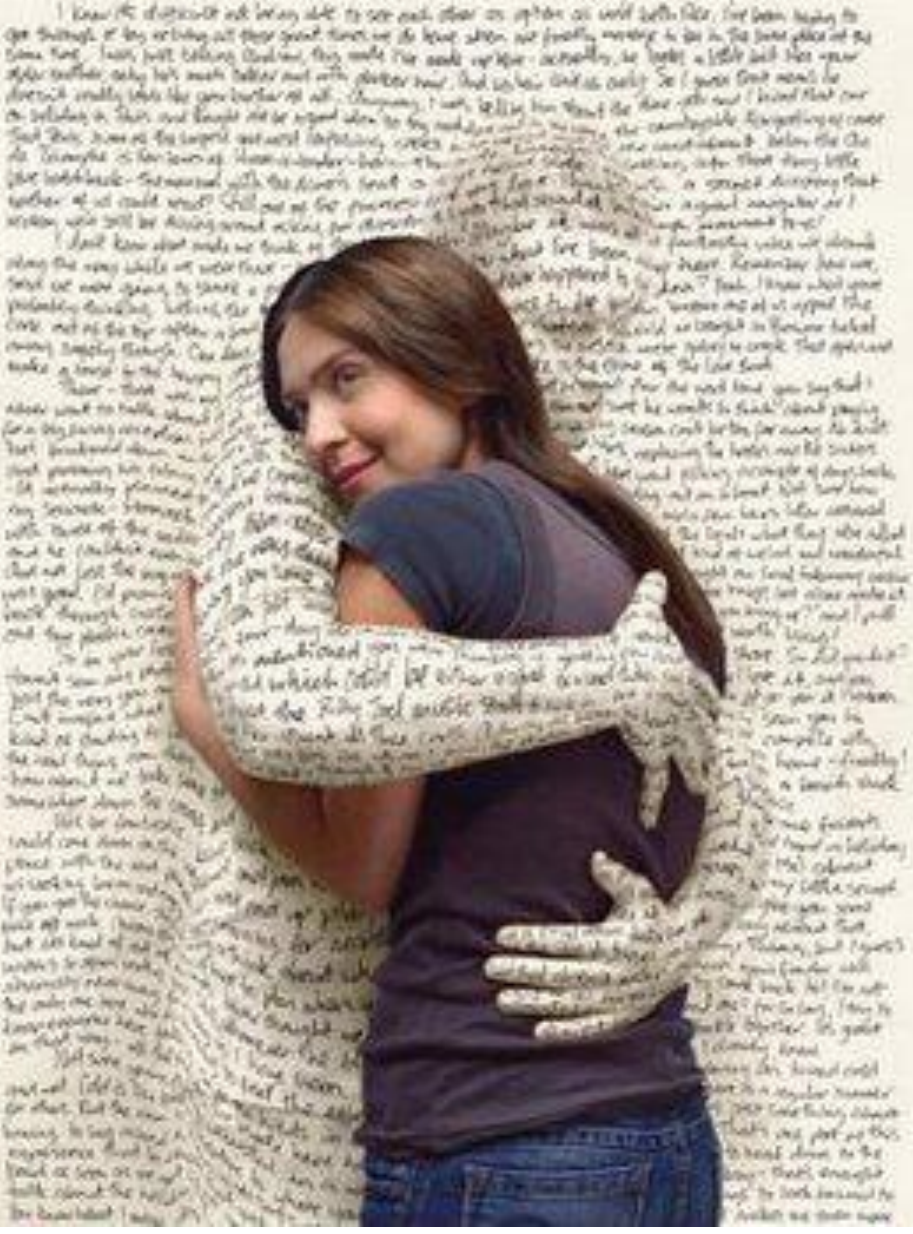

ESCOLA DE COMUNICAÇÕES E ARTES Doutorado em Ciências da Comunicação Teoria e Pesquisa em Comunicação 


\section{Capítulo 8}

\section{Leitura e Comunicação}

\section{Signo da Relação: a Construção Social dos Sentidos}

$\mathrm{Na}$ visão de leitura como ato social e processo interacionista e transacional, os saraus de leitura compartilhada, seja a leitura vocalizada ou a silenciada, portou-se como uma estratégia para que os leitores pensassem coletivamente e construíssem os sentidos do texto em grupo. Os saraus foram experiência de um instante e um local de encontro social, espontâneo, em que os participantes "pensam alto" sobre textos. Através dos saraus é possível fazer o desvelamento de textos em grupo pela interpelação dos sujeitos que desenvolvem o senso crítico e a ação consciente capaz de transformar o ato de ler, de simples automação, em ação política de leitura. Os momentos coletivos dos saraus quase em sua totalidade levavam à observação crítica do texto, ao respeito pelo outro, ao desenvolvimento da colaboração e à cooperação nos eventos de leitura. Nessa experiência de leitura compartilhada os interlocutores negociam, concordam, discordam, têm oportunidade de manifestar-se criticamente, de descobrir ou refutar as ideologias subjacentes ou não aos textos. O sarau como estratégia propiciou a observação de como na leitura se dá a relação entre a bagagem de um leitor com a do outro, com a do autor, com o contexto em que a leitura ocorre. Mais que uma simplória interação leitor-texto, nos saraus a leitura torna-se um evento social e cultural. O caráter informal e despretensioso do sarau permite e assumi a inconstância, a imaterialidade, a imprevisibilidade no processo de leitura ao invés de ser direcionar ou instrumentalizar a leitura o que propicia poucas oportunidades ao leitor de se expressar, de questionar, de ser valorizado nas suas manifestações como colaborador. Isso não quer dizer que a construção e as relações do grupo ocorram de forma harmônica. Na maioria das vezes, as relações são assimétricas, tensas, de conflitos porque os sujeitos envolvidos não enxergam o mundo nem a si próprios da mesma forma.

Vimos nessa viagem de capítulos e noções, diferentes abordagens sobre a leitura

e também como o ensino e a aprendizagem da leitura constituem numa atividade complexa por causa de sua natureza simbólica. É possível compreender a leitura sob a 
perspectiva do texto inerte, onde a construção do sentido é vista basicamente como um processo de extração ou assumir o papel do leitor, ainda que não o idealizado, quando a leitura se manifestaria como um processo de atribuição de significados; e ainda como propomos neste trabalho, a visão do diálogo, ao mesmo tempo conflituoso e conciliador entre o texto e o leitor (ou seria mais apropriado falarmos em leitores), compreendendo a leitura como um processo interativo/transacional, quando a ênfase está na relação com o outro cujo resultado é a criação processual da construção do(s) sentido(s). Nessa proposta a construção dos significados não é feita a partir do texto em si por um processo de extração, mas a partir do leitor, que não extrai do texto e sim atribui a ele um significado.

Desta noção, citaremos a atividade de ler como leitura compartilhada (explícita, como nos saraus, ou implícita, como nas leituras silenciosas), uma forma de interação do leitor com a linguagem escrita, com o autor, com as condições situacionais, com todas as variáveis que envolvem o processo de leitura e, especialmente, com outros leitores. Na experiência compartilhada, os participantes atuam contribuindo com suas experiências e conhecimento, formando elos de troca e ajuda mútua. O texto é sempre uma atividade narrativa que pode ser considerada um ato comunicativo, um processo interacional, em que narrador(es) e ouvinte(s) atuam na produção dos significados da narrativa. Segundo a perspectiva da comunicação, da interação social, a leitura se daria em três termos: Sujeito-Outro-Objeto. Esse é o princípio do que citamos como o Signo da Relação, uma espécie de manifesto abaixo ao racionalismo reducionista e por uma ética da compreensão a partir da estética da recepção. Como bem sentenciou Dimas Kunsh (2009):

Associada ao ato ora feliz e ora trágico do conhecimento, a epistemologia da compreensão e a proposição ética que lhe serve de base avançam muito além do patamar vez e outra fútil dos bons 
propósitos e das boas intenções, para se alçar corajosamente à condição de dimensão fundante desse mesmo conhecimento. O gesto humano da compreensão resulta, pois, em termos objetivos, em mais conhecimento. Produz conhecimento de tipo não mutilante nas relações com as pessoas, a sociedade e a natureza, assumindo, desse modo, legitimamente, o estatuto de uma verdadeira episteme. Em suma, mais bem e profundamente conhece quem se projeta compreensivamente a caminho. (KUNSH, 2009: 276)

Isto porque por algum tempo, na literatura da comunicação social foi comum esquematizar o processo de comunicação como monológico e unidirecional. Havia a pressuposição de que o emissor da mensagem seria um sujeito ativo e o receptor dela seria um sujeito passivo, cuja função seria apenas a de receber e decodificar o significado contido na mensagem. Esse modelo simplista não permite, aparentemente, compreender a complexidade dos processos de comunicação, pois a vida em si, e a vida social são dinâmicas. Os bens necessários ao ser humano circulam no ambiente social e podem ter valores e significados distintos para cada indivíduo ou grupo, época e lugar. Esses fatos, bens e valores relevantes para a sociedade exigem que a linguagem e o sistema de mediação de significados intertextuais sejam igualmente dinâmicos. Assim, na medida em que as relações individuais e sociais tornam-se mais e mais complexas e amplas, a linguagem e o sistema significados culturais vão sendo re-atualizados pelos mediadores sociais, os quais, através de suas narrativas sobre a realidade, recriam-na e dão estabilidade, mesmo que de forma transitória, ao quadro geral de referências culturais vigentes em certo contexto. Em resumo, a linguagem e a comunicação em geral precisam ser diferentes para poderem ser compreendidas por pessoas diversas em contextos distintos. Por isto, a construção da narrativa, embora com a marca de criação de seu autor, permanece inacabada, pois cada destinatário irá completá-la com base em seu respectivo sistemas de valores. 
Noção compartilhada com outros autores. Da mesma forma que defende o pesquisador Laan Mendes de Barros (2009) - Das poéticas da mídia às estéticas da recepção - também a autora Cruz (1986) sustenta que um texto qualquer (não necessariamente o texto literário) contém um conjunto de significados propostos pelo autor do texto e que, ao ser recepcionado pelo destinatário (pelo leitor do texto original), passa a ter outros significados que tal destinatário agrega ao texto em conexão com sua própria realidade. Nesse sentido, o texto original simboliza certa realidade, e a leitura desse texto pelo destinatário simboliza outra realidade, que pode ou não coincidir com aquela imaginada e narrada pelo autor do texto. Desse modo, a leitura ou recepção do texto original dá origem à outra narrativa, agora feita pelo leitor. Para sustentar esse ponto de vista, a autora revisa os fundamentos tradicionais da ciência a partir da distinção entre sujeito e objeto, recupera os fundamentos da crítica estruturalista para, então, assinalar os traços essenciais do novo paradigma da estética da recepção. Pondera que a questão fundamental não é a de saber qual o detentor do sentido - se o texto, se o sujeito - mas sim compreender como texto e sujeito se constituem, e de que modo o sentido os atravessa (CRUZ, 1986). Assim sendo, Cruz ressalta que o sujeito leitor é uma realidade exterior ao texto e que interage com o texto, constituindo ele também leitor - o sentido desse texto conforme o contexto em que ambos se ligam para o acontecimento interativo. Portanto, o texto em si mesmo não carrega um significado definitivo, pronto e acabado, construído pelo seu autor. Ao contrário, produzido o texto, o autor perde em grande parte o controle do seu conteúdo, pois este conteúdo será fixado também pelo leitor, com o significado que tal leitor vier a atribuir ao texto dentro do contexto assinalado. A alteridade entre leitor e obra marca, portanto, a construção do significado do texto segundo o paradigma da estética da recepção. A autora observa que o estruturalismo contribuiu para evidenciar que a obra não é portadora da verdade do autor e que a estética da recepção, por sua vez, evidencia que o crítico não é o 
decifrador de uma verdade construída na própria obra. A obra não é revelada pelo crítico, pois qualquer narrativa a respeito dessa obra resulta de um processo de leitura em que um sujeito historicamente condicionado constrói a dialogia e os sentidos da obra. Ao proceder assim, o leitor cria outra obra, na qual se implica. A cada leitura o leitor de um texto estabelece os sentidos que podem resultar da obra; faz relações entre a verdade do autor e a verdade estabelecida pelo próprio leitor ao interagir com o texto. Ao recriar a narrativa textual, o leitor atribui significações intertextuais que dão coerência e lógica à sua própria realidade, essa realidade contida na sua narrativa. Eis porque o profissional de comunicação social, como autor-narrador-mediador de fenômenos e de significados sociais, estabelece com a sociedade em que se insere o signo da relação, pois a informação veiculada por meio da narrativa daquele autor está afeta aos atores sociais e tem significação para esses atores (MEDINA, 2006).

Pensar na recepção (aisthesis/estética) no processo da produção (poiesis/poética) é reconhecer como própria a elucidação do professor Laan Barros (2008): “a comunicação é uma questão de mediações mais que meios; questão de cultura e, portanto, não só de conhecimento, mas de re-conhecimento, de identificação”. Entender a recepção como processo ativo, experiência estética, e aceitar a produção de comunicação social como ação mediadora. Neste processo de comunicação, mais que a tecnologia, se destacam os sujeitos mediados - produtor e fruidor.

É essencial a contribuição de Medina (2003) para compreender como ocorrem os processos de mediação de significados sociais intertextuais. Em essência, esses processos de mediação acontecem nas narrativas que os sujeitos fazem a respeito da realidade caótica em que vivem, a fim de reorganizá-la num cosmos compreensível. A abordagem de Medina envolve o que Morin (2005) denominou pensamento complexo, que combina a razão com as percepções intuitivas e com as manifestações emocionais do ser humano, elementos estes enfeixados de maneira a possibilitar a mais ampla 
expressão da inteligência, bem como maior percepção e compreensão do mundo. Baseada em estudos precedentes de Lohisse (1969), cujo pensamento introduziu no Brasil, a abordagem de Medina põe em relevo o papel do sujeito como mediador dos significados intertextuais da realidade e da sociedade em que se insere, de modo a ser, simultaneamente, por um lado, sujeito observador dessa realidade e, por outro lado, partícipe e construtor da mesma realidade que observa. Nesse contexto, tal sujeito necessariamente compartilha - e se solidariza com, está afeto a - os fenômenos da realidade que observa, compreendendo-a mais profundamente, decodificando e mediando os signos dessas relações humanas. A autora insiste que a construção social dos sentidos acontece na rua, no cotidiano das pessoas, essencialmente por meio da narrativa oral, a qual denomina oratura, em contraste com a literatura escrita, a 'escritura'. As intersecções possíveis entre literatura e oratura dão origem a uma produção intertextual, de que o narrador é ao mesmo tempo autor e personagem que media e compartilha os significados de sua produção com o resto da comunidade (MEDINA, 1988). Esse sujeito expressa na sua narrativa o pensamento simbólico referido por Eliade (2002), bem como os diferentes elementos culturais fragmentados que interagem na vida cotidiana (às vezes de modo tão conflitante). Tal narrador reorganiza todos esses elementos, dá a eles significação própria no contexto social em que acontecem as relações e assim, intervém e transforma sua realidade.

A narrativa é essencial para atribuir significação ao cotidiano social porque é uma resposta humana à angústia provocada pelo caos. A inteligência humana é dotada da capacidade de produzir significados durante a narrativa da realidade e, assim, consegue transformar o caos em cosmos. É por meio da narrativa que o sujeito reconstrói-se, expressa sua humanidade, afirma a si próprio e responde à desorganização da vida. A narrativa é, assim, necessidade essencial do ser humano porque possibilita que ele interfira na sua realidade e se emancipe em todos os sentidos. Ao narrar - lendo 
ou escrevendo -, o sujeito cria outra realidade, mais harmônica, justa, solidária. Além disso, o ato de narrar dá espaço a insights criativos, requer a manifestação de afeto e o exercício da intuição, que então o narrador-autor-personagem organiza de forma racional, inteligível e dotada de significação. Isto exige que o narrador-autorpersonagem da realidade domine o conhecimento técnico-científico que lhe é útil para organizar e racionalizar sua narrativa, e também que desenvolva sua inteligência emocional e intuitiva a ponto de poder captar e mediar os significados intertextuais das relações sociais de que participa. É assim que o narrador-autor-personagem capta, atribui significação e expressa os desejos anônimos dispersos no inconsciente coletivo, e no seu próprio inconsciente, compartilhando-os com os demais atores sociais. As sociedades contemporâneas dependem cada vez mais de agentes sensíveis e capacitados para realizar tais mediações simbólicas, qualquer que seja o instrumento que utilizem para a construção de suas narrativas.

No processo de comunicação social, o referido mediador atua tanto antes da veiculação das mensagens como depois da distribuição delas. Antes da veiculação, o mediador é verdadeira voz social, fonte de significados sociais e emissor da mensagem. Depois que a mensagem tiver sido distribuída, o mediador também a recebe e a reelabora, como um sujeito anônimo ou não, confirmando ou transformando a significação disseminada na sociedade. É muito interessante refletir sobre esses pontos. A concepção de que haveria irresistível direcionismo do comunicador e passividade total do receptor da mensagem comunicada, por meio da qual seria possível aos poderes dominantes ou hegemônicos impor "às massas" elementos culturais e significados específicos, não levava em conta a dialética intrínseca do processo comunicacional. Medina (1988), citando Enzensberger, chama a atenção para o fato de que, a partir de certo ponto, uma rede de comunicação e de disseminação de conteúdos de interesse dos poderes hegemônicos escapa ao seu controle porque apresenta uma dinâmica dialética 
que altera o significado desses conteúdos. Esta observação decorre do fato de que as sociedades avançadas dependem do livre intercâmbio de informações orientadas para a ação e para a renovação, e não para a passividade contemplativa. A comunicação é organizada para interferir no presente e não para manter a tradição. A autora pondera que houve época em que se considerava que os meios de comunicação social reproduziam uma cultura industrializada, em que a importância dos criadores dessa cultura era eliminada ou minimizada, pois esses meios de comunicação eram governados pelos princípios da rentabilidade e da homogeneização cultural impessoal. Todavia, exatamente por ser um produto cultural, não é possível homogeneizá-lo de modo absoluto. Qualquer manifestação cultural abrange o elemento criativo. Por esse motivo, surge uma relação dialética entre o sistema de produção ou reprodução cultural e o criador dos elementos culturais absorvidos no sistema. Mesmo no bojo da "cultura de massa", o criador de certo produto cultural o assina: imprime nesse produto sua marca com que se distingue dos demais. Resgatando a contribuição de Moles (1973), Medina (1988) faz referência à divisão cultural em antiga e nova. A cultura antiga corresponderia à cultura em forma de pirâmide e seria construída essencialmente por meio do sistema educacional. A nova cultura seria um mosaico, em oposição à imagem da pirâmide, e teria duas camadas: a de "cultura de massa", alimentada pelos meios de comunicação social; e outra camada composta por criadores integrantes da sociedade intelectual. A primeira camada - de "cultura de massa" - gera um fluxo contínuo de mensagens de todos os tipos, com múltiplos sentidos, mas consubstanciado em fragmentos culturais dispersos num sistema de comunicação que não lhes dá suporte duradouro. A segunda camada - a dos criadores - absorve os fragmentos dispersos no sistema de comunicação, reorganiza esses fragmentos e os transforma em novas mensagens que serão, então, reabsorvidas pelos meios de comunicação social. Realizase, assim, um processo dinâmico e dialético entre as duas camadas. Nesse jogo 
cambiante, instável e dinâmico, cada indivíduo atua como mediador dos significados intertextuais disseminados no meio social e, então, depois de absorvê-los, processá-los e reorganizá-los, transformando-os num cosmos, passa a reinseri-los no quadro geral de signos sociais.

Esse sentido de "co-produção", como é óbvio, pressupõe a interação dialógica, polifônica e polissêmica entre os emissores de mensagens com significados e os receptores dessas mensagens. Em decorrência desses aspectos, cada interlocutor interage não só com o outro, mas, e também, relaciona o conteúdo de cada discurso com todo o universo cultural dentro do qual o processo de comunicação se desenvolve. Cada interlocutor conecta os conteúdos simbólicos da narrativa com fatos do seu meio ambiente presente, com momentos anteriores de sua vida, com as expectativas que tem para o futuro, com seus sentimentos gerais ou específicos, com as imagens e símbolos míticos que trafegam no seu inconsciente. Procedendo assim, cada interlocutor deixa de ser um receptor passivo das mensagens que lhe são dirigidas pelo outro interlocutor. Ao contrário, ao receber cada mensagem, o interlocutor-receptor a amplia, porque nela incorpora o seu sistema de significados e de valores culturais. Reorganiza a narrativa que lhe foi dirigida e cria outra, mais complexa porque inclui tanto a mensagem original como a narrativa do interlocutor-receptor. Desse modo, este último recria a realidade contida no discurso original e, então, apresenta essa nova realidade ao seu interlocutor, que agora passa a ser receptor e reproduzirá todo o processo. Trata-se, então, de um processo comunicacional dialógico, porque envolve participação ativa e transformadora de cada interlocutor; polifônico, porque abrange não somente os signos contidos em determinada mensagem, mas sim todos os signos culturais que o receptor utilizar para receber, decodificar, compreender, reorganizar e reeditar a mensagem original; e cíclico, porque tal processo continua a se reproduzir até o momento em que a comunicação é interrompida. 
O Signo da Relação nega o processo de comunicação social reduzido ao modelo ingênuo do emissor ativo e do receptor passivo, nem que fique subjugado pelo paradigma positivista que lhe impõe discursos fragmentados e autoritários. Há, portanto, a falência das linguagens midiáticas que apelam exclusivamente à persuasão (lógica e razão), uma vez que a narrativa da cena viva traz os atores sociais, a relação dos afetos e consequentemente os espaços de não-razão do ser humano. Atualmente, a comunicação social deve ser concebida como um processo multidimensional que abrange não só os sistemas simbólicos da linguística, mas também o universo cultural em que estão inseridos os participantes de tal processo.

Na perspectiva da leitura, sob o Signo da Relação, metaforicamente, o leitor, cheio de sonhos e perguntas, sempre tende a se jogar sobre o texto (em sua variedade de suportes). O texto é uma rede colocada na base do processo protegendo o leitor na eventualidade de uma queda. Se irá se jogar ou não, assumir riscos maiores ou menores na leitura, depende do grau de confiança do leitor na segurança dessa rede. Descer à rede do texto é muitas vezes adentrar na mente e se aventurar abaixo e acima da superfície da consciência, trabalhar com muitas hipóteses e poucas certezas, caminhar no caminho obscuro e instável do inconsciente. Uma das descobertas dessa pesquisa é justamente que o leitor não está sozinho nesse ato de se doar ao texto, ao contrário, ele faz parte de uma comunidade consumidora de textos.

Quando, na teoria da leitura, põe-se à ênfase no leitor, concentra-se basicamente nesse caminho "obscuro" da mente do leitor. Por mais obscuro e incerto, o caminho ainda que leve tempo - pode levar ao encontro do Outro e é nesse momento que acontece a leitura compartilhada e transformadora. Encontro que pode ser dificultado quando o leitor fica preso às grades do texto ou no seu mundo individual, ou facilitado quando esse é convidado para partir em busca do Outro. Nessa busca, mais cedo ou mais tarde, o leitor chega ao momento da apoteose precedida de vários indícios: do 
silêncio à releitura, passando pela aprendizagem da convivência de um grupo social, da religação entre pessoas interessadas num determinado assunto, o que o autor Swales (1990) chama de comunidade discursiva.

$\mathrm{Na}$ apoteose a leitura completa-se como um processo interativo, deixando de ser um simples encontro furtivo com as palavras do texto ou com si próprio (leitor), passando a ser um encontro permanente com o Outro. Nesse momento, o texto cumpre seu papel social de tirar o leitor da categoria de excluído para posicioná-lo na de participante.

É oportuno perceber que o processo de interação não acontece no isolamento e na individualidade. É necessário que haja pelo menos dois elementos e que esses se relacionem de alguma maneira. No ato de leitura, o leitor e o texto são apenas duas combinações possíveis. Outras possíveis seriam a combinação entre leitor e autor, as bagagens que o leitor traz em sua história de vida, seu conhecimento de mundo e seu conhecimento linguístico, o leitor e os outros leitores, ou ainda a interação em rede de todos esses elementos. Independente do que se sobressai no momento da leitura devido à diversidade de caminhos que o leitor possa seguir, o mais relevante é que quando esses elementos se relacionam um com os outros eles se modificam. E se estamos de alguma foram conectados, ligados entre nós e o mundo, quando lemos e essa leitura nos modifica, consequentemente ocorre - ainda que de forma pequena (nem por isso irrelevante) - uma mudança no mundo.

A opção pela abordagem interativa neste trabalho engloba aspectos multi e interdisciplinar para compreender a Leitura. Apesar da tentativa de abordar alguns desses aspectos nos capítulos anteriores, a presente tese situa-se na área de abrangência do objeto de estudo da Comunicação, uma vez que propõe a visão do processo de leitura como, acima de tudo, um lugar de comunicação, de religação, de encontro dos indivíduos, do encontro de todos nós, do Signo da Relação. Olhar a leitura sob a visão 
da Comunicação poderia contribuir no sentido de que a compreensão desse processo não estaria focada no texto, no leitor ou na comunidade discursiva, mas no modo de comunicação entre eles, como todos esses aspectos se auto-influenciam. Ainda sob esse olhar, seja com foco no texto, no leitor ou na comunidade discursiva, vê-se que essas perspectivas não são como pontos de vista fixos, mas dinâmicos, em constante mudança que interagem durante o processo extremamente complexo da leitura.

Numa retrospectiva do conteúdo citado em capítulos anteriores, percorremos uma linha de raciocínio crítico para posicionarmos diante da proposta da Leitura enquanto Comunicação sob o Signo da Relação: a construção social dos sentidos.

Os estudos sobre leitura quando focalizados no texto, sedimentaram alguns paradigmas com a busca da invisibilidade do texto que se transforma num intermediário didático e transparente entre leitor e conteúdo. O resultado da visão do "texto transparente" é a popularidade das fórmulas de inteligibilidade usando parâmetros como a extensão e a simplicidade da palavra, das estruturas das frases e dos textos. O que ficou implícito nesse modelo paradigmático é a estratificação do leitor, a formatação dos leitores em competências genéricas. Essa visão desencadeia uma série de paradigmas em relação à leitura. Por exemplo, a leitura como obtenção do conteúdo que subjaz ao texto. O conteúdo não está na história de leituras, não está no leitor, nem na comunidade, mas exclusivamente no próprio texto. Nessa perspectiva a construção do significado não envolve diálogo nem negociação entre o leitor e o texto e muito menos atribuição de significado por parte do leitor. Ler seria extrair o conteúdo e a melhor leitura é aquela relacionada à quantidade de conteúdo extraído.

Tal extração do significado se daria, portanto, por um processamento sequencial e linear, da esquerda para a direita, de cima para baixo, palavra por palavra, frase por frase, página após página. Um dos principais defensores dessa teoria foi Gough, em seu artigo de 1972 com cerca de trinta páginas intitulado Um segundo de leitura onde 
descreve o mecanismo da leitura. Metalinguisticamente, o próprio Gough comprovaria que os significados não parecem ser produto de um homem, mas de um conjunto de seres humanos, de uma época. No ano de 1985, ele mesmo refutou o que tinha escrito em Um segundo de leitura num breve pós-escrito que pode ser resumido com uma frase do próprio escrito: "O modelo está errado" (Gough, 1985). Destruiu com uma pequena nota aquilo que havia construído num artigo de trinta páginas.

Outra consequência dessa forma de compreender a leitura é que o texto produziria sempre os mesmos significados, pelo menos em leitores de um mesmo nível de competência. Neste modelo é fácil aceitar que um leitor mais competente dite o significado ao menos competente - uma situação típica de sala de aula, quando o texto significa aquilo que o professor diz que ele significa.

Ainda nesse raciocínio, a "qualidade" da leitura dar-se-ia pela capacidade do leitor de reconhecer letras e palavras. Ler seria basicamente decodificar: transformar o código escrito no código oral. De fato, numa análise das diferentes habilidades e fontes de conhecimento do leitor, a competência lexical é o fator crítico para a compreensão do texto escrito, mas, pela abordagem interativa, não é o único, como nos demonstram casos de surdos de nascença que aprendem a ler sem jamais terem ouvido uma palavra. O acesso ao significado na leitura, ao menos com leitores proficientes, pode então se dar diretamente da imagem gráfica ao significado. Ou ainda pode ser mais complexo. A leitura depende também de informações não-visuais presentes na memória do leitor. A experiência nos saraus constatada que ao ler em voz alta, muitas palavras são omitidas, acrescentadas e trocadas, sem que o leitor se dê conta.

Ainda que na prática argumenta-se quanto aos diferentes objetivos e posturas diante da leitura podendo levar à objetividade e à conveniência da extração linear de significados, ainda assim a leitura linear encontra barreiras quando o processo cognitivo da leitura mostra-se aleatório nos seres humanos. Numa leitura de hipertexto, por 
exemplo, a trajetória do leitor deixa rastros visíveis das possibilidades de diferentes caminhos. Os caminhos trilhados por cada leitor ao longo de diferentes links são provas incontestáveis das possibilidades de leituras, colocando em cheque a sustentação de que o significado está no texto. Ainda que fisicamente o texto seja o mesmo, cada trajetória feita por cada leitor sobre o mesmo texto constitui um texto diferente. A tese do significado único deixa de existir.

Sabe-se que diante de condições iguais, o leitor com um vocabulário mais extenso entende melhor um texto, portanto a capacidade de decodificação tem uma forte correlação com a compreensão de leitura. No entanto, se a relação fosse de causa e efeito, o ensino do vocabulário deveria garantir uma melhor compreensão do texto; nem sempre é o que acontece. O que se percebe é que existe uma intercausalidade implícita no complexo ato de ler. Um exemplo de variável é a capacidade de estabelecer conexões com diferentes partes do texto, viver a narrativa e não a fragmentação do texto em partes: capítulos, frases, palavras, letras. $\mathrm{O}$ ato da leitura, na perspectiva única do texto, pressupõe que cada leitor em cada leitura acione exatamente os mesmos significados na mesma variação de possibilidades. A experiência que temos com a leitura no dia a dia mostra que isso não é verdadeiro. Os leitores não apenas são diferentes entre si, como também o mesmo leitor realiza diferentes leituras do mesmo texto. A compreensão do texto estaria, assim, não apenas relacionada ao domínio do vocabulário, mas na presença de outras variáveis. Isto poderia explicar porque mesmo com o aumento do índice de alfabetização no mundo e no País, há também uma alta porcentagem dos chamados analfabetos funcionais.

Já na abordagem dos estudos de leitura focalizando no leitor, a construção do sentido é acionada por (pré) conceitos do leitor. Conceitos esses relacionados à experiência de vida do leitor, seus conhecimentos linguísticos, textuais e enciclopédicos, além de fatores afetivos, sua preferências. A experiência afetiva 
desperta a atenção, uma vez que o leitor reconstrói a narrativa a partir da representação mental que possui do mundo (memória episódica). Nessa abordagem, o texto não apresentaria um sentido novo ao leitor, mas o faria buscar, dentro de sua memória, um sentido que já existente.

Essa visão provocou uma revisão nos estudos exclusivos aos textos, uma vez que a construção dos sentidos se daria com o uso de diferentes fontes de conhecimento (linguístico, textual, enciclopédico, episódico) resultando num processamento que não é o da extração e sim o da atribuição de sentido. A participação ativa do leitor faz com este elabore e teste as proposições do texto, confirmando-as ou rejeitando-as.

A perspectiva da leitura como atribuição de sentido, qualificaria o leitor como um estrategista, capaz de avaliar e controlar a própria compreensão, permitindo-se, a qualquer momento, a adoção de medidas corretivas. O leitor proficiente deveria então ser capaz de identificar os problemas de incompreensão e utilizar-se de estratégias para melhorar sua compreensão seguindo os diferentes objetivos de leitura. Escolher entre a leitura rápida, a esmiuçadora, a cautelosa e outras possibilidades. Portanto, o leitor saberia se posicionar correspondendo aos objetivos da leitura: ler para escola, para si mesmo, para um sarau; ler para aprender, obter uma nota melhor num exame, a fim de conseguir um emprego, se orientar numa rua desconhecida, montar um eletrodoméstico; ler como passatempo, ler na cama para adormecer, ler por prazer, por obrigação, para obter forças num momento difícil da vida, impressionar alguém ou ainda ler para executar uma cerimônia religiosa. Na perspectiva exclusiva do leitor, ninguém leria sem um (pré) objetivo, e cada objetivo pressupõe uma estratégia de leitura coerente com o objetivo.

Ainda na abordagem do leitor, a proficiência de leitura conjuga-se com a capacidade do leitor premeditar o texto, habilidade essa desenvolvida pela prática de leitura. O leitor então se utiliza de seu conhecimento prévio para direcionar sua 
trajetória pelo texto. Quanto maior a experiência maior a possibilidade de prever um substantivo seguido ou não de um adjetivo, uma frase de conjunção subordinada seguida de uma oração principal. Na leitura de um leitor proficiente prevê-se a estrutura e até mesmo o conteúdo do texto através das convenções de escrita: uso de tabelas, gráficos, ilustrações.

Em resumo, a perspectiva da leitura com foco no leitor, preocupa-se com os mecanismos ocorridos da mente do leitor durante a leitura. O leitor não é um elemento passivo que apenas extrai significado do texto, e sim ativo, atribuindo significado, fazendo previsões, separando amostras, refutando, confirmando e corrigindo hipóteses sobre o texto.

As críticas levantadas a respeito do leitor como centro na teoria da leitura é que dando ênfase aos aspectos cognitivos, são deixados a um plano menos importante os aspectos afetivos e principalmente os sociais. A leitura é vista como processo e não como um produto.

Além disso, a responsabilidade do significado é atribuída somente ao leitor. Como o significado não é extraído é atribuído, o leitor tem a soberania de atribuir o significado que lhe aprouver, independente do texto e de outras leituras. A construção do significado está imune a qualquer injunção externa que possa interferir na privacidade e no direito que o leitor tem de interpretar. A compreensão não é ditada, mas construída na relação do texto lido e a experiência vivida por cada leitor. Nessa abordagem minimiza-se a autoria do texto e neutraliza-se a possibilidade da leitura transformadora uma vez que o leitor sempre está lendo a si mesmo e não ao texto.

A leitura não é um processo isolado e sim, como nos propõe o Signo da Relação, transacional que transforma todos os elementos envolvidos. O texto é construído não só pelo autor ao produzi-lo, mas também pelo leitor ao lê-lo. Uma vez que há a compreensão é proveniente de um conjunto de variáveis, acontece a compensação. Se 
houver um déficit de uma das variáveis, por exemplo, vocabulário desconhecido, o leitor compensará, por exemplo, com a afetividade, a estética do texto.

Além disso, como estamos propondo no trabalho, a leitura pode não ser apenas uma atividade mental, mas também uma atividade social. Com a presença de Outro é possível haver uma troca de experiências e idéias sobre o texto. $\mathrm{O}$ uso de textos de apoio, ou a presença de um leitor tido como proficiente, no caso do professor, por exemplo, ou ainda o próprio autor, é mais um canal por onde ocorre essa troca. A leitura compartilhada deixa de ser uma atividade individual para se tornar um comportamento social, onde o significado não está nem no texto nem no leitor, mas nas convenções de interação social em que ocorre durante o ato da leitura. A leitura como comportamento social é validada pela comunidade e não por uma classe ou pessoa autoritária.

Nesse sentido, o que pode estar acontecendo é a iniciação da leitura na escola quando o leitor é solicitado, quando não obrigado, a ler um texto que não foi escrito especificamente para ele, exigindo pré-requisitos que de uma forma ou outra lhe foram sonegados. Na medida em que não tem o domínio das práticas sociais previstas pelo discurso hegemônico, o leitor não tem como se inserir na comunidade dos consumidores de texto (leitores e escritores) e permanece um excluído. E a situação se torna cíclica, pois como a leitura acontece apenas superficialmente e direcionada, será muito difícil para o leitor conhecer o potencial emancipador da linguagem.

Dentro do Signo da Relação, do paradigma social da leitura, a construção do sentido é um processo de interação onde as pessoas desvelam o desconhecido e mudam e ao mudar mudam a sociedade em que estão inseridas. Para se tornar leitor e, por extensão, escritor, o indivíduo precisa ser aceito e aceitar-se no grupo e usufruir dos privilégios dispensados à comunidade, sendo o corporativismo um "risco" inerente ao grupo. Para entrar no grupo é preciso que o principiante seja institucionalizado, que se aproprie da linguagem adequada, que domine o conhecimento compartilhado entre os 
participantes. Nos saraus de leitura, esses mecanismos ocorrem com todos os leitores simultaneamente à leitura. Assim, na perspectiva interacionista, adiciona-se ao conhecimento do indivíduo as convenções que regem as relações entre os membros de um determinado grupo e a liberdade criativa que porventura possa surgir.

Tanto a abordagem exclusiva do texto quanto a do leitor oferecem problemas que dificultam uma definição mais adequada de leitura. Na perspectiva do leitor, há o problema da qualificação e proficiência. Se o leitor ignorar a trama do texto, acabará por conjugar o verbo ler apenas na forma intransitiva e a leitura torna-se uma atividade unicamente introspectiva.

A proposta do trabalhão é que ler seja um verbo de valência múltipla. A leitura pode alargar nossos horizontes profissionais, culturais e pessoais, pois desempenha múltiplas funções sociais: a fruição, o prazer ou deleite, aquisição de conhecimento e informação; leitura para pesquisa; leitura para fins religiosos, auto-ajuda. E, no meu ponto de vista o mais importante: a leitura compartilhada é uma condição básica para formar sujeitos capacitados, inseridos na sociedade, naturalmente prontos a exercitar sua cidadania, participando crítica e ativamente da construção da sua e da história de seu povo, formulando seus próprios critérios para se questionar como sujeito no seu ato de pensar, sentir e atuar, ultrapassando a fronteira da cultura local a partir da abertura a outras proporções culturais. 


\section{Capítulo 9}

\section{Relações, nexos e conexões}

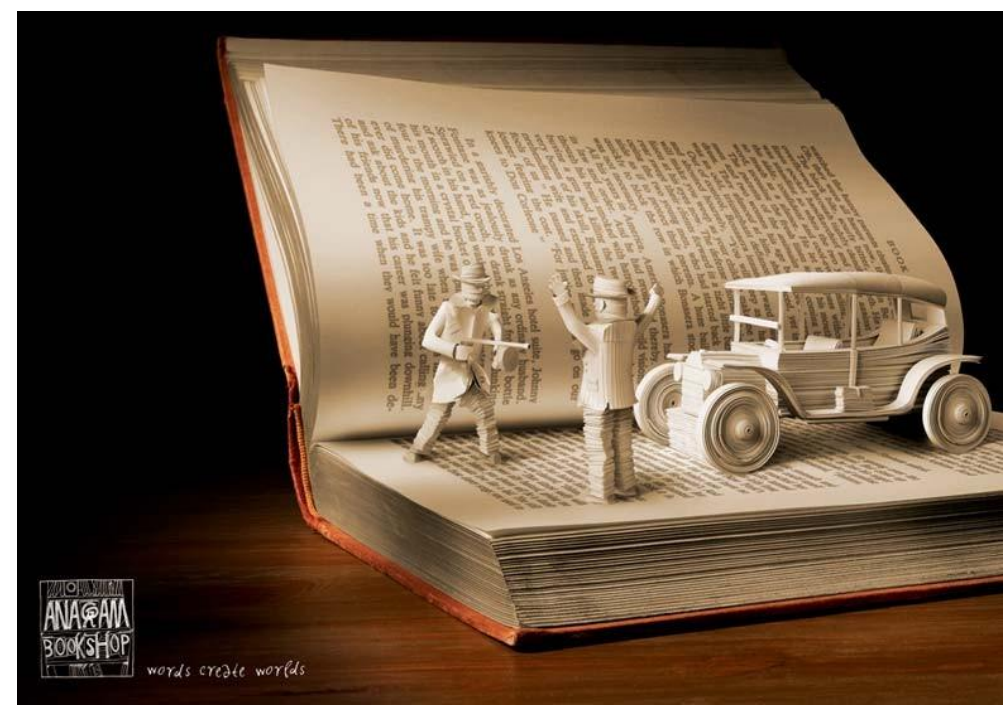

ESCOLA DE COMUNICAÇÕES E ARTES

Doutorado em Ciências da Comunicação

Teoria e Pesquisa em Comunicação

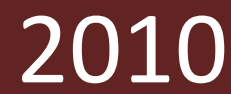




\title{
Capítulo 9
}

\section{Percurso São Paulo de Perfil}

\section{Relações, nexos e conexões}

\begin{abstract}
Este trabalho não se fundamenta em si só. É mais um "filho" de um caminho percorrido coletivamente por pesquisadores do Fórum Permanente Interdisciplinar da Escola de Comunicações e Artes da Universidade de São Paulo desde a década de 1990 (a partir desta data como grupo). Neste capítulo, entre vários trabalhos e leituras que normalmente nos apropriamos inconscientemente, cito reflexões e propostas epistemológicas que serviram como base para continuidade de um pensamento uno de compreensão da complexidade dos temas do mundo, enfim, da vida, através da reflexão científica da Dialogia, da Comunicação Social, do Signo da Relação.
\end{abstract}

Não por um acaso, ao escolher o Signo da Relação como paradigma para reflexão da leitura enquanto comunicação, optei, para as leituras nos saraus, por textos publicados na série São Paulo de Perfil. Isto porque a tese está fundamentada em outras pesquisas do Fórum Permanente Interdisciplinar, neste capítulo relacionadas.

A começar pela gênese do projeto São Paulo de Perfil. Iniciativa da professora Cremilda Medina, foi inspirada na experiência de um jornalista norte-americano, que em 1980, com um conjunto de pequenas brochuras, propôs-se a contar a história oral de personagens anônimos novaiorquinos. Segundo o jornalista, Arthur Tobier, entediado com a mesmice da grande imprensa, ele resolveu agregar-se a um grupo de artistas do East Side dos EUA e começou a escrever uma série de histórias de personagens da cidade que, devido à filosofia adotada pela chamada imprensa, possivelmente nunca teriam a oportunidade de ter voz nos meios de comunicação convencionais ou em documentos oficiais. 
Naquele ano, no entanto, mais do que o encontro físico da pesquisadora Medina com o jornalista novaiorquino e com suas brochuras, houve, segundo relata, a comunhão pelo desencantamento com a grande imprensa. Na época Medina também batalhava intensamente no jornalismo diário, época em que o Brasil vivia a construção da abertura ou redemocratização, porém combatia, em seu próprio trabalho, o enfraquecimento do tônus criativo nos trabalhos jornalísticos. Isto porque as empresas jornalísticas haviam se voltado exclusivamente para a era da informatização, mas na contramão da modernização, passaram a tolher os "ímpetos esquerdistas", dando mais valor à notícia curta e aos projetos de computação gráfica. Resultado: a atrofia dos projetos sociais dentro da grande imprensa. Alternativa? Tobier encontrara nas brochuras, Cremilda na pesquisa acadêmica. Resolveu voltar à Universidade de São Paulo de onde saíra, na repressão, em 1975, delineando com seu doutoramento em 1986, ano de sua volta ao ambiente acadêmico, seu próprio manifesto contra a razão soberana, e a favor da aventura do Hemisfério Direito fertilizando o Hemisfério Esquerdo. Aventura essa exemplificada em sua tese de doutorado - Modo de Ser; Mo'Dizer - quando na segunda parte do volume (O Diálogo Possível), a pesquisadora enraizou a reflexão teórica na sua caminhada humana de afetos. Em 1987, numa sinergia de pesquisa, ensino e extensão, começava o Projeto São Paulo de Perfil, um livro temático de narrativas sobre São Paulo que vem concretizando nestas vinte e sete edições a veiculação da chamada "grande reportagem".

Pela perspectiva da grande reportagem, o jornalista colombiano Raul Osório Vargas, com a proposição de estudar as novas tendências do Jornalismo na América Latina, desenvolveu um mestrado que prosseguiu no doutorado, sobre os livros publicados na década de 1990 da série São Paulo de Perfil, produzindo assim o primeiro documento de pesquisa sobre a renovação dos jovens autores da Escola de Comunicações e Artes no jornalismo latino-americano. Os autores estudados na 
dissertação de mestrado de Raul Vargas - A reportagem literária no limiar do século XXI, o ato de reportar, os jovens narradores e o Projeto São Paulo de Perfil - formam um grupo de mais de 500 autores (jornalistas ou não), que se destacam em suas atuações profissionais pela responsabilidade social e pela marca autoral.

Ainda, para compreender melhor a série São Paulo de Perfil, vale ressaltar que no início em 1987, estava incorporada à grade curricular dos alunos através de uma disciplinar regular. Estes faziam rigorosamente uma edição por semestre, sem uma política de pautas definida. Faz parte do projeto, portanto, que os autores-narradores se lancem em uma zona de risco em busca da re-humanização das pautas. Desta proposta adveio o primeiro livro-reportagem monotemático - Virado a Paulista -, enganchado na Constituinte de 1987. A repercussão sentida através do primeiro livro da série e, sobretudo, do segundo - Vozes da Crise -, também realizado em 1987, a série se definiu numa política editorial de dois grandes fôlegos: quem faz o perfil de São Paulo - o protagonismo; e quais os grandes enfrentamentos de quem vive e sofre a atualidade - a saga humana. A contribuição social da série que vem rascunhando o perfil da cidade de São Paulo foi aprofundada no mestrado de Alex Sander Alcântara, Sentidos da Metrópole, quando o pesquisador aborda a relação entre cidade, jornalismo e o espaço público urbano, mostrando como o jornalismo, que nasceu com as cidades, contribuiu para ampliação do espaço público - grande parte dos lançamentos do São Paulo de Perfil ocorreu em espaços públicos da cidade: bairros, câmara de vereadores, metrô, Pátio do Colégio, sempre tentando reunir a comunidade inserida no assunto, como o lançamento de $O$ Primeiro Habitante (vol. 10), ocorrido no metrô Consolação com a participação dos [índios] protagonistas do livro, como lembra Alcântara (2009). O mestrado ainda mostra como a coleção de 27 livros-reportagem da série São Paulo de Perfil ampliou os espaços públicos na metrópole em si mesma, alcançando, pela identificação, outras localidades como a Bahia e Mococa, no interior de São Paulo, por exemplo. 
Deste contexto de estudos sobre o São Paulo de Perfil, ressurgiu a proposta desta tese que se propôs a dar continuidade à pesquisa de narrativas da contemporaneidade hoje diluída em disciplinas extracurriculares (optativas) ministradas pela professora doutora Cremilda Medina e em laboratórios de escrita, por parte dos autores-criadores das narrativas dos livros. A intenção foi debruçar também na significativa contribuição dos leitores, em atividades formais curriculares, em projetos de extensão universitária, ou em grupos de leitura informais. É importante ressaltar para o caminho da pesquisa, que em todas as ocasiões, os leitores, que voluntariamente se dirigiam aos saraus, estavam propensos, portanto 'abertos' ao livre exercício da leitura.

Já de antemão, as leituras nos saraus, contrapunha-se à hipótese de justificativa para o que se diz ser um baixo índice de leitura de livros no Brasil colocando como portas fechadas, as questões de econômica e de política. Os primeiros saraus apontaram, primeiramente, para uma entrada da leitura pela porta da cultura. Como observou Paulo Quadros (2009), em seu doutorado Epistemologia da leitura: um campo interpretativo de inserção dos meios digitais no contexto escolar:

A epistemologia da leitura reforça a necessidade de se incorporar a não-linearidade como sensibilidade textual. $\mathrm{O}$ conceito de leitura, neste aspecto, passa a agenciar significados mais abrangentes do que o factual, pois decorre de um sentido interpretativo diferente que aponta para outros pressupostos filosóficos, culturais e etimológicos, atualizados continuamente nos moldes dos desdobramentos impingidos ao pensamento contemporâneo. Ou seja, a idéia de leitura passa a detonar mais elasticidade em sua abordagem referencial, pois concebe o sentido de ler como princípio de desenvolvimento de vários estilos de acuidade (agudeza de observação). A vida, o mundo, a natureza e o homem tornam-se laboratórios vivos de análise interpretativa abertos à experimentação permanente. (QUADROS, 2009: 89) 
Neste contexto de esporádicos contatos com leituras e alguns feedbacks de leitores da série São Paulo de Perfil, a partir de 2004 instigou-se qual seria o resultado de um estudo mais sistemático e em maior escala de leitura dos ensaios-reportagem da série. Estruturaram-se, assim, estudos da recepção através de uma clara proposta de leitura em saraus. Esta pesquisa, porém, há de se pontuar, é precedida do conhecimento empírico acumulado através de um convênio de 1989 firmado com a Secretaria de Educação do Estado de São Paulo, quando por oito anos foi possível receber o retorno da leitura crítica de alunos de segundo grau em um grupo de escolas selecionadas pela Secretaria na $16^{\text {a }}$ Delegacia de Ensino. Pelo convênio, professores de várias disciplinas incorporaram os livros-reportagem aos seus planos de trabalho com os alunos que respondiam com textos à respectiva leitura e o resultado retornava à pesquisa original.

Do feedback destas narrativas do São Paulo de Perfil, seja no convênio e agora pelos saraus, podemos sintetizar pelo menos cinco vertentes de reflexão. A legibilidade dos livros - do convênio de 1989 viu-se que os leitores de 16 e 17 anos, consideraram bem mais atraentes o protagonismo da saga contemporânea dos heróis anônimos do que a avaliação exclusivamente discursiva e teórica dos livros didáticos. Foi possível registrar a sedução da linguagem e dos temas, pois muitos dos alunos destacaram sérias desavenças, em suas histórias escolares, com a leitura de clássicos, de obras recomendadas pelos professores. Nos saraus, com a abrangência de outras faixas etárias, a contemplação diante do protagonismo se fez presente pela narrativa viva e verossímil com a recriação das cenas do cotidiano; identificação - ao invés do discurso teórico da persuasão, os leitores manifestaram-se com certa preferência pela informação humanizada, exemplificada na cena cotidiana e pelos anti-heróis da aventura contemporânea. Sobre a fraca atuação com resultados práticos da linguagem da persuasão (razão) utilizada em publicidades para prevenção do vírus HIV nas décadas de 1980 e 1990, em contraposição a eficiência dos grupos de apoio, onde o 
protagonismo ganha força e atinge o emocional para então chegar à racionalidade e à reflexão, aprofundou com mais apropriação a pesquisadora Ellen Cristina Geraldes em sua dissertação de mestrado intitulada Cláudio Abramo, sujeito possível (1995). Nos saraus, houve claras manifestações de proximidade do leitor com a leitura, de identificação, por exemplo, quando a narrativa dispunha sobre as cenas de trânsito na cidade de São Paulo, um tema que abrange todas idades, raças, rico ou pobre; cidadania - devido a data da leitura (o convênio consolidou-se em 1989), os jovens eleitores, embebidos na Constituição de 1988, também faziam das leituras das reportagensensaios um meio de informação sobre a cidade, as migrações e através dos protagonismos, também sobre alguns impasses contemporâneos. Nos saraus vieram a se confirmar que os leitores de certa forma rejeitam ou não se interessam pelo conteúdo devido às cargas conceituais, o 'peso' do mundo das idéias, os quadros puramente estatísticos, as teses ou as informações dogmatizadas. Quando em textos assim claramente posicionados as discussões limitaram-se apenas em 'concordo ou discordo do texto'; convergência de mídias - apesar da escolha do suporte livro, a de se ressaltar a consciência de que a escrita no papel é apenas uma possibilidade; e que outras linguagens e suportes também se fundamentam na escrita verbal; construção social dos sentidos - a proposta da leitura prosódica e grupal dos saraus pontuou a visão de leitura como ato social, colocando-se como uma estratégia para que os leitores envolvam-se manifestando ao mesmo tempo e no mesmo lugar os sentidos e significados construídos coletivamente. Nessa experiência de leitura compartilhada os interlocutores negociam, têm oportunidade de manifestar-se criticamente, de descobrir ou refutar as ideologias subjacentes ou não aos textos. A leitura nunca é individualizada, mesmo quando os leitores não se encontram dentro de um mesmo recinto. Os sentidos são sempre construídos coletivamente, pelo mosaico de leituras até mesmo sendo em tempos e espaços diferentes. A leitura em grupo potencializa a gama de significados 
porque é o resultado de uma soma real de sons e de sentidos. Em grupo, compartilhamse as inquietudes, a incompreensão, as limitações. A leitura em grupo nos saraus exemplificou concretamente a leitura como troca, como ato dialógico, como Comunicação. Em grupo os significados saudavelmente se misturaram e criaram novas relações entre os signos forjando novos significados, estimulando uma releitura e reescritura do mundo, ampliando possibilidades para o futuro por meio de "novas" perguntas e quem sabe, possíveis "novas" respostas. 


\section{Capítulo 10}

\section{Destino final - Tramas e amarrações}

ESCOLA DE COMUNICAÇÕES E ARTES

Doutorado em Ciências da Comunicação

Teoria e Pesquisa em Comunicação

2010 


\section{Capítulo 10}

\section{Destino final}

\section{Tramas e amarrações}

Álbum de fotos e diário de bordo. O que ficou da viagem...

Inspirada como participante ativa (coordenadora e autora) nas três últimas publicações da série São Paulo Perfil e instigada pelos estudos de epistemologia do Fórum Permanente Interdisciplinar onde se propõe a inversão do espírito positivista e mecanicista da Ciência pela experiência dialógica, pelo exercício de ir ao Outro, às situações cotidianas ainda não descobertas ou não compreendidas; foi assim que iniciei esta aventura de pesquisa.

Enquanto autora de ensaios-reportagem da série, além de estar investida do espírito de pesquisa, surgiu, a partir das aulas de pós-graduação feitas ainda como aluna convidada, certa curiosidade para investigar de maneira prática, em laboratório, se de fato as narrativas de ensaio-reportagem eram tão transformadoras para os leitores, como eram para os autores segundo seus próprios testemunhos. Daí a ideia dos saraus.

Além da curiosidade de ordem prática, também havia a hipótese de que, como em outras áreas da Ciência, estudados pelo grupo de pesquisadores do Fórum, a compreensão da Leitura e da relação da sociedade com o livro, tanto enquanto Ciência quanto consequentemente enquanto Práxis, também poderia estar contaminada pelo que se identificou como a atrofia dos sentidos humanos mecanizados pela visão científica da coisificação, da visão do mundo enquanto interação entre sujeito (eu) e objeto (mundo), engessando, assim, a inteligência humana através da dogmatização de conceitos fechados, neste caso conceitos e dogmas sobre livro e leitura. Estes conceitos deveriam ser revisto - como propõe esta tese -, modificados por concepções diferenciadas de alfabetização, educação e também de livro, especialmente com a crescente multiplicação e popularização de outros suportes audiovisuais, como a própria televisão, cinema, celular e internet.

Nesta perspectiva de entender o fenômeno da Leitura, através da pesquisa bibliográfica identificou-se uma dualidade de abordagem da Leitura, do ato de ler: primeiro como ato de decodificação e depois pela fruição, pela construção de sentido. 
Assim, a estrutura textual da tese inicia-se pela Apresentação onde se expõem os métodos, metodologias e intuições que nortearam esta pesquisa, especialmente a proposta do Signo da Relação, inicialmente pincelada, mas que vai de desenhando e se revelando como caminho epistemológico no percurso do trabalho, inclusive, em determinados momentos da narrativa da pesquisa, pela sua veemente negativa, o que não se confirmava.

Ainda na estrutura da narrativa da tese, fez-se então necessário, na Introdução, a contextualização sócio-cultural a respeito da escolha da proposta da pesquisa, muito instigada por um momento histórico próprio dos âmbitos nacionais e mundiais. $\mathrm{O}$ tema Leitura ganhou esforços conjuntos e destaque como tema na agenda setting da sociedade internacional, preocupados com a identificação de um fenômeno global que seria a diminuição da leitura de livros com o suporte-base de folha de papel.

Já no primeiro capítulo, portanto, numa inversão do que poderia ser uma ordem "mais pedagógica" - indo da reflexão teórica para a prática dos saraus - houve a tentativa de primeiro ambientar o leitor desta tese quanto à proposta de laboratório que é a experimentação dos saraus com leitura de ensaios-reportagem da série São Paulo de Perfil. Em Cruzeiro pelos Saraus, com a recriação com linguagem escrita verbal de um sarau regido por Izaura Marques propõe-se o início de uma viagem fenomenológica pela compreensão primeiro do sarau, depois da Leitura, sob a suspeita (depois confirmada) de que a aparente apatia em relação à produção textual, seja pela leitura, seja pela escrita, talvez esteja camuflando outras questões que vão além da dificuldade de decodificação de grafias e fonemas, tais como a exclusão social, a incredulidade da participação pela intervenção social, que dentre muitas outras situações cotidianas, estaria se manifestaria também no processo, na relação com leitura.

No segundo capítulo, apresentamos ao leitor da tese, para melhor compreensão da proposta epistemológica, pinceladas da história de Izaura Marques, e como e onde há o encontro de sua experiência de vida como atriz de rádio-novela com a vivência de leitura nos saraus. Do sucesso e observação de seu modo peculiar de apresentar o texto em voz alta aos participantes dos saraus, surge então um modo peculiar de realizar os saraus que chamamos carinhosa e, com certa licença poética, no terceiro capítulo de Isaurau, onde o objetivo principalmente é a leitura em voz alta do texto verbal, sutilmente dramatizada - mas sem cenários ou figurinos -; apenas com o trabalho da pronúncia das palavras e estímulo à vivência das palavras, das entonações, do texto. Neste terceiro capítulo, questionamos como a capacidade de leitura do sinal alfabético ganhou um significado no mundo contemporâneo restrito à condição de poder e 
dominação, esquecendo-se da condição de gozo e mágica da inexplicável necessidade imperiosa de ler e escrever.

No capítulo quatro, introduzimos outra variável para expandirmos a compreensão de leitura. Mais do que somente decodificar palavras ou assimilar informações, no século vigente a leitura também se apresenta como importante momento de formação e transformação dos sujeitos, não de forma individualista, e sim de forma coletiva. A proposta da leitura prosódica, em voz alta, dramatizada, com ritmo e melodia, começa a se delinear no quarto capítulo e consolida-se no quinto capítulo, quando convidamos o leitor para refletir o caminho epistemológico de compreensão da leitura onde identificamos uma inversão de foco: não no livro, não no autor, nem no leitor em si, mas sim no processo, na "acontecência" da leitura onde todos estes elementos se misturam. Esta complementação se faz necessário, porque como a Ciência entende o ato de ler tem profunda ligação de que lugar a leitura ocupa no espaço social.

No capítulo seis, colocamos a variável escola, onde ficou identificada na alfabetização a prática de uma leitura artificializada, fragmentada, de decodificação, focada vezes no livro, vezes no autor, ficando em segundo plano o contexto e o histórico de leitura dos leitores. Além disso, o aperfeiçoamento da leitura com os elementos prosódicos (processo posterior ao aprendizado da decodificação, ou seria concomitante?) para anos vindouros, que nunca chegam, causando assim certa deficiência na competência de leitura, na interpretação e consequentemente na formação cidadã, o que retomamos no capítulo sete, quando eu pesquisadora fiz uma leitura particular e crítica das campanhas publicitárias como instrumento de propagar a ideologia de políticas públicas de incentivo à leitura. Muitas destas campanhas surgiram no Brasil a partir do ano de 2005 e mostraram estar centradas em concepções ultrapassadas da imagem de leitura e de leitores, ficaram focadas no livro, portanto na relação sujeito-objeto, ou seja, o foco das campanhas e das políticas públicas acentuou o senso comum e estereotipado de que leitura está ligada ao livro e colocá-lo à disposição da população, por si só já é incentivar à leitura. As campanhas foram citadas como o exemplo ao contrário da proposta da leitura presente na tese de que mais do que a relação entre sujeito-leitor e objeto, seja este objeto o livro ou qualquer outro suporte, a leitura é sempre o lugar de relação dialógica entre sujeitos, entre leituras, e vislumbrar este encontro de pessoas (tipos diferentes, de épocas e pensamentos diferentes) é ter consciência do processo de escrita que permite expandir o processo de interpretação e compreensão do texto. Esta noção é elucidada no capítulo oito da tese, quando apresentamos a leitura como ato social e processo interacionista e transacional, de 
construção coletiva e compartilhada de sentidos, onde leitores "negociam, concordam, discordam, têm oportunidade de manifestar-se criticamente, de descobrir ou refutar as ideologias subjacentes ou não aos textos".

Ainda na proposta de construção coletiva, metalinguisticamente relata-se no capítulo nove em quais outros trabalhos científicos e pesquisas a tese está fundamentada, posicionando esta tese como uma contribuição e parte de um quadro maior de descobertas feitas nas últimas três décadas de pesquisa pessoal da pesquisadora Cremilda Medina e duas décadas de trabalho coletivo do grupo do Fórum Permanente Interdisciplinar.

Em suma, ao discorrer nos capítulos da tese percebemos, seja na proposta de compreensão da leitura na Ciência (epistemológica), ou na compreensão e prática nas escolas, bibliotecas, ou sob a ótica de iniciativa pública, há o predomínio de compreensão da Leitura e também do ensino da linguagem como um processo de extração mecânica da pronúncia das palavras. Embora essa consciência fonológica também seja importante para o processo cognitivo do ato de ler, o que se questiona é se esta extração da pronúncia é anterior (e não concomitante) à extração do sentido, da vivência e contextualização do texto, da visão de que o texto, a leitura é o lugar e momento de encontro interpessoal. Isto porque a observação sistemática de mediação de leitura de outras pesquisas e também desta tese mostrou que as habilidades construídas mediante a prática da leitura não seguem uma ordem prevista. Vê-se que a competência de leitura passa pelo processo de alfabetização que hoje no Brasil e no mundo parece ter um desvio de foco: ao invés de ter o aprendizado como objetivo, foca-se no ensino do professor; ao invés da vivencia da língua, a mecanização do processo cognitivo de decodificação. Ao excluir o significado no início do processo - na alfabetização - em benefício do ato mecânico da decodificação, parece, como mostra a tese, que o sentido acaba sendo igualmente excluído do texto gráfico (qual é o interesse desse texto para mim?), do ato de ler (ler para quê?) e enfim da aprendizagem (aprender para quê?).

Compreender a leitura como um processo de comunicação, proposta central desta tese, implica dizer que a leitura é uma atividade de encontro e de trocas sinérgicas entre o $\mathrm{Eu}$ e o Outro. A leitura é o momento de fazer conexões de sentidos representativos aos leitores/escritores. Assim, ao mesmo tempo em que a leitura é um tanto de experiência individual enquanto processo neurológico (decodificação), a leitura - enquanto interpretação, apropriação e transformadora - também é uma experiência interpessoal e dialógica, uma vez que os sentidos são construídos coletivamente, isto porque os sentidos não se encontram no texto/autor, exclusivamente, ou no leitor, 
exclusivamente; ao contrário, os sentidos situam-se e nascem do encontro harmônico ou conflituoso, não importa, de leitores e de leituras. O texto, a partir desta ótica, seria apenas um instrumento de registro de mais uma possível leitura, neste caso, a do autor do texto.

A leitura é, portanto, o processo, o encontro entre autor-texto-leitor sob determinada circunstância; é o encontro entre sujeito, entre leituras, onde a construção dos sentidos é realizada de forma coletiva. E este encontro entre sujeitos, ademais de muitas conjecturas ou teorizações, precisa simplesmente acontecer, com todas as incógnitas e imprevisibilidade que este fenômeno possa ter. Portanto direcionamentos, instrumentalização ou antecedência de resultados pode ser apenas uma aposta que pode não se concretizar e uma vez não realizada não quer dizer que a leitura, este encontro entre sujeitos, não aconteceu. Pensar a leitura como um processo de comunicação é compreender a leitura como o encontro cheio de trocas entre sujeitos. Mediados por um contador de história, por um livro ou por uma tela - seja de televisão, de cinema ou de computador - ainda assim é um encontro comunicacional.

Esta concepção - de que a leitura é o encontro entre sujeitos/leituras - implica dizer que o ato de ler precisa ser estimulado como um "encontro coletivo" onde o leitor enquanto sujeito é também protagonista. Sob a percepção do Signo da Relação, este processo comunicacional da leitura não acontece como uma transmissão de informações, mas sim como o encontro onde os sentidos são gerados dialogicamente e ouvidos como vozes sociais que interagem de forma dinâmica e constantemente. O texto é, portanto, o motivo criado por um autor para que ocorra um momento de encontros, de dialogia, de interação, de comunicação interpessoal; o resultado deste encontro é a leitura.

A você leitor deste volume, obrigado pela leitura, e espero ter proporcionado um interessante encontro aqui na narrativa desta tese. 


\section{REFERÊNCIAS BIBLIOGRÁFICAS}

ABREU, M. \& SCHAPOCHNICK, N. Cultura Letrada no Brasil. Coleção Histórias da Leitura. São Paulo, Fapesp, 2005.

AGOSTINHO, Santo. Confessions, IV, 3. In: MANGUEL, Alberto. Una Historia de la Lectura. Lumen, 2005.

ARISTÓTELES. Poética. São Paulo: Arts Poética, 1993.

BAGNO, Marcos. Preconceito Lingüístico. O que é. Como se faz. São Paulo, Edições Loyola, 2002.

BAKHTIN, M. M. Toward a Philosophy of the Act. (trad. V. Liapunov). University of Texas Press, 1993.

Marxismo e Filosofia da Linguagem. São Paulo, Hucitec, 1986, $3^{\circ}$ edição. Cia. das Letras, 1992.

O problema do texto. In: Estética da criação verbal. São Paulo: Martins Fontes, 1992.

BARR, A. \& FEIGENBAUM, A. The Handbook of Artificial Intelligence, volume I-II. William Kaufmann Inc., Los Altos, California, 1981.

BARTHES, Roland. Aula. Trad. de Leyla Perrone-Moisés. São Paulo: Cultrix, 1978. . Crítica e verdade. Lisboa, Ed. 70, 1987.

BOSI, Alfredo. Por um historicismo renovado. Teresa (Revista de Literatura Brasileira), FFLCH. Ed. 34, n. 1, p.9-47, 1o. sem. 2000.

BRASIL. Constituição Federal. 1988 (e subseqüentes documentos legais). Lei de Diretrizes e Bases da Educação Nacional (Lei Complementar $n^{\circ}$ 9394/96).

Lei no 10.639/03 (e documentos legais de regulamentação) Brasil - MEC. Pluralidade Cultural, in PCNs, Brasília, 1997.

Pluralidade Cultural, in Temas Tranversais, PCNs (5a a 8a séries), Brasília, 1998.

BUBER, Martin. Do diálogo ao dialógico. São Paulo, Perspectiva, 1982.

BUITONI, Dulcilia. De volta ao Quintal Mágico. A educação infantil na Te-Arte. São Paulo: Ágora, 2006.

CAGLIARI, Luiz Carlos. Alfabetização e lingüística. São Paulo: Scipione, 1989.

CANDIDO, Antonio. O Direito à literatura. In: Vários escritos [edição revisada e ampliada]. São Paulo: Duas Cidades, 1995. 
CANCLINI, Nestor. As culturas populares no capitalismo. São Paulo, Brasiliense, 1983.

CARVAlHO, J. G. Herculano de. Teoria da linguagem. Coimbra: Atlântida, Tomo I, 1979.

COSERIU, Eugenio. Do sentido do ensino da língua literária. Trad. Evanildo Bechara. In Confluência, Revista do Instituto de Língua Portuguesa. Rio de Janeiro, n. 5, 1993.

CRUZ, M. A estética da recepção e a crítica da razão impura in Revista de Comunicação e Linguagens. Lisboa, Centro de Estudos de Comunicação e Linguagens, jun. de 1986.

DAMÁSIO, António R. O Erro de Descartes - Emoção, Razão e Cérebro Humano. São Paulo, Companhia das Letras, 2003.

DE FELIPPES JUNIOR, Bernardo. Mídias eletrônicas, impressas e alternativas: o que são e como utilizar. Brasília: SEBRAE, 1995.

DESSE, J. Como estudar. Tradução. São Paulo, Editora Estudantes, 1981.

DIETZSCH, Mary. Espaços da linguagem na educação. São Paulo, Humanitas, 1999.

DURAND, Gilbert. A imaginação simbólica. São Paulo, Cultrix: Editora da Universidade de São Paulo, 1988.

ECO, Umberto. Obra aberta. São Paulo: Perspectiva, 1991. . Sobre literatura: ensaios. Trad. Eliana Aguiar. Rio de Janeiro: Record, 2003.

ESCARPIT, Robert. La revolution du livre. Paris, Unesco, 1967.

FERREIRA, A. Novo Dicionário Aurélio da Língua Portuguesa. Editora Nova Fronteira, Rio de Janeiro, $2^{\circ}$ edição.

FONSECA, Maria. Letramento no Brasil. São Paulo, Global editora, 2004.

FREIRE, Paulo. Professora sim, tia não. São Paulo: Olho D’Água, 4 ed. 1994.

GUARESCHI, Neuza; COMUNELlO, Luciele Nardi; NARDINI, Milena; \& HOENISCH, Júlio César. Problematizando as práticas psicológicas no modo de entender a violência. In: Violência, gênero e Políticas Públicas. Orgs: Strey, Marlene N.; Azambuja, Mariana P. Ruwer; Jaeger, Fernanda Pires. Porto Alegre. Editora PUCRS, 2004.

INNERARITY, Daniel. A Transformação da Política. Lisboa, Editorial Teorema, 2002. JAUSS, Hans Robert. A história da literatura como provocação à teoria literária. Trad. Sergio Tellaroli. São Paulo: Ática, 1994.

JAUSS, Hans Robert. Literatura medieval e teoria dos gêneros. São Paulo, Ática, 1986. 
KLEIMAN, Ângela. Texto e Leitor: Aspectos Cognitivos da Leitura. Campinas, SP: Pontes, 2000.

KOCH, V. I. A Inter-Ação pela Linguagem. São Paulo, SP: Contexto, 2000 - Coleção Repensando a Língua Portuguesa.

KUHN, Thomas. A estrutura das revoluções científicas. São Paulo, Perspectiva, 1989.

MAFFESOLI, Michel. O Conhecimento Comum. São Paulo, Brasiliense, 1988.

MARCÍlIO, Maria. História da Escola em São Paulo e no Brasil. São Paulo, Imprensa Oficial, 2005.

MANGUEL, Alberto. Uma história da leitura. São Paulo, Companhia das letras, 1997.

MEDINA, Cremilda. A arte de tecer o presente, Narrativa e Cotidianos. São Paulo, Summus Editorial, 2003.

MEDINA, Cremilda (org.). Novo Pacto da Ciência, Primeiro Seminário Transdisciplinar - a Crise de Paradigmas (anais). São Paulo, ECA, 1991. - Novo Pacto da Ciência 2, Do Hemisfério Sol: projeto $O$ discurso fragmentalista da ciência. São Paulo: ECA/USP: CNPq, 1993. Novo Pacto da Ciência 3, Saber Plural: o discurso fragmentalista e a crise de paradigmas. São Paulo: ECA/USP: CNPq, 1994. . Novo Pacto da Ciência 4, Sobre vivências no mundo do trabalho. São Paulo: ECA/USP: CNPq. 1995.

Novo Pacto da Ciência 5, Agonia do Leviatã: crise do Estado Moderno. São Paulo: ECA/USP: CNPq, 1996.

. Novo Pacto da Ciência 6, Planeta Inquieto: direito ao século XXI. São Paulo: ECA/USP: CNPq, 1998.

Novo Pacto da Ciência 7, Caminhos do Saber Plural: dez anos de trajetória. São Paulo, ECA/USP: CNPq, 1999. Novo Pacto da Ciência 10, Energia, Mei Ambiente e Comunicação Social. São Paulo, ECA/USP: CNPq, 2009. . Entrevista, o Diálogo Possível. São Paulo, Ática, 1986. . Símbolos e narrativas.. São Paulo, Secretaria de Estado do Meio Ambiente, 1997. . Povo e Personagem. Canoas, Ed. Da Ulbra, 1996. Ciência e Jornalismo. Da Herança positivista ao diálogo dos afetos. São Paulo, Summus Editorial, 2008.

MERTON, Robert K. Sociologia, Teoria e Estrutura. São Paulo, Mestre Jou, 1970. MORAIS, J. A arte de ler. São Paulo: Ed. UNESP, 1996. 
MORIN, Edgar. A religação dos saberes. Bertrand Brasil, 2002.

O problema epistemológico da complexidade. Lisboa, Publicações

Europa-América, s/d.

RESTREPO, Luis Carlos. O Direito à Ternura. Petrópolis, RJ, Vozes, 1998.

RETTENMAIER, Miguel. \& JACOBY, Sissa. Além da plataforma nove e meia: pensando o fenômeno Harry Potter. Rio Grande do Sul, Universidade de Passo Fundo Editora, 2005.

SANTOS, Boaventura de Souza. Introdução a uma Ciência Pós-Moderna. Rio de Janeiro, Graal, 1989.

SOARES, Magda. Letramento: um tema em três gêneros. Belo Horizonte: Autêntica, 1998.

SUAIDEN, Emir. A biblioteca pública no contexto da sociedade da informação. Ci. Inf., Brasília, v. 29, n. 2, p. 52-60, maio/ago. 2000.

VIDAL, Diana e Hilsdorf, Maria. Tópicas em história da educação. São Paulo, EDUSP, 2001.

WEBER, Renée. Diálogos com Cientistas e Sábios, a Busca da Unidade. São Paulo, Cultrix.

ZAPPONE, M. H. Y. Práticas de leitura na escola. Tese. Campinas, Unicamp, 2001.

ZILBERMAN, Regina. Letramento literário: não ao texto, sim ao livro. In PAIVA, M.; PAULINO, G. \& VERSIANI, Z. (org.). Literatura e letramento. Espaços, suportes e interfaces. O jogo do livro. Belo Horizonte, Autêntica/CEALE/FaE/UFMG, 2003. Leitura: perspectivas interdisciplinares. São Paulo: Ática, 1988. 